2. To: (Receiving Organization)

Distribution

5. Proj./Prog./Dept./Oiv.:

HTI

8. Originator Remarks:

For approval/release
3. From: (Originating Organization) COGEMA Engineering

6. Design Authority/ Design Agent/Cog.

Engr.

NA
4. Related EDT No.

NA

7. Purchase Order No.:

NA

9. Equip./Component No.:

$\mathrm{NA}$

10. System/Bldg./Facility:

200Gen

11. Receiver Remarks: 11A. Design Baseiine Document? [] Yes [X] No

NA

13. Permit/Permit Application No. :

NA

14. Required Response Date:

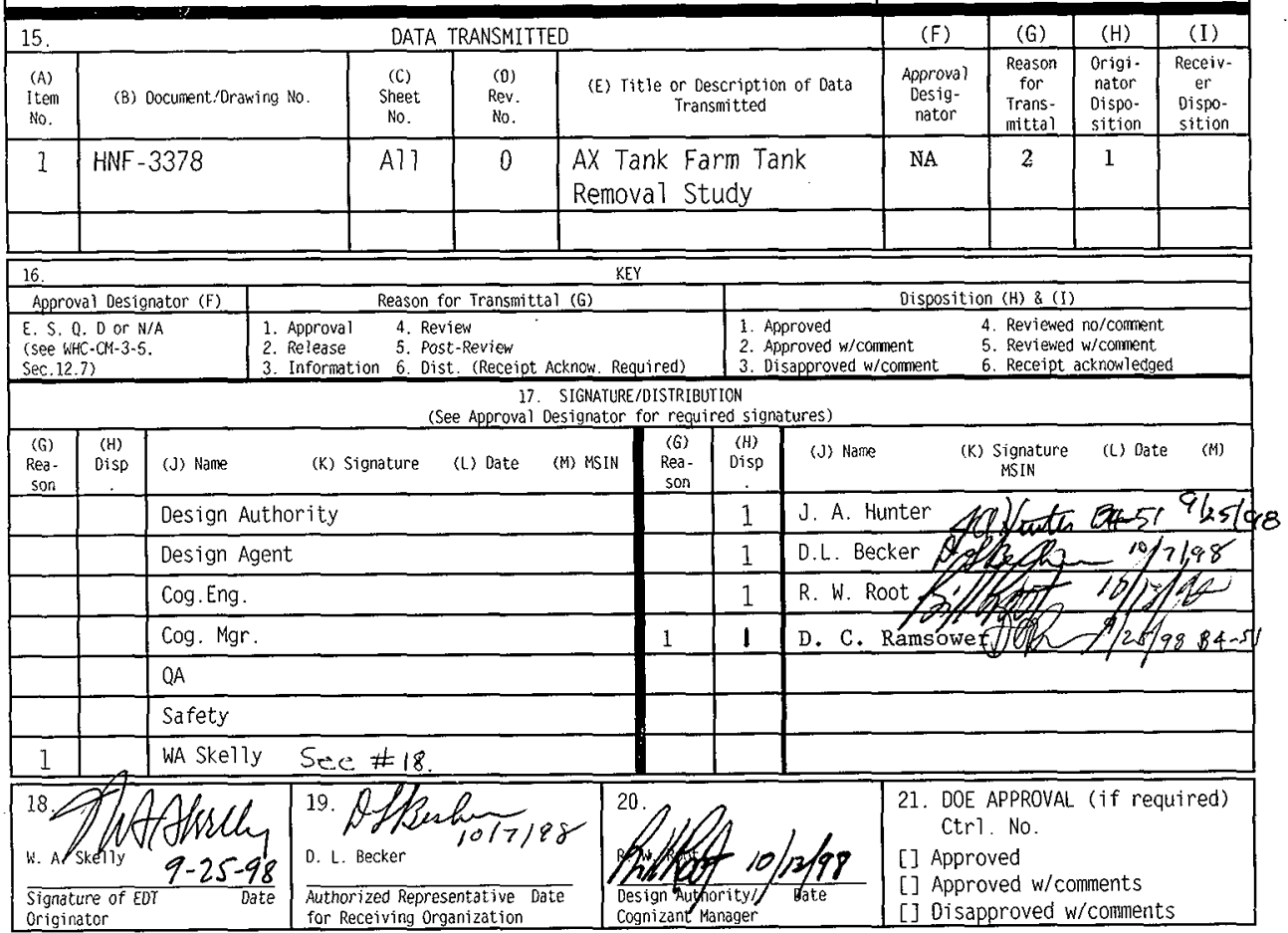




\section{AX Tank Farm Tank Removal Study}

W. A. Skelly

COGEMA Engineering Corporation. Richland. WA 99352

U.S. Department of Energy Contract DE-AC06-96RL13200

EDT/ECN: 624328

UC: 510

Org Code: $08 \mathrm{E} 00$

Charge Code: D25E3

B\&R Code: EW3130010

Tota1 Pages: 176200

Key Words: AX Tank Farm, Hanford Tanks Initiative, HTI, tank demolition, closure of tank farms

Abstract: This report considers the feasibility of exposing, demolishing, and removing underground storage tanks from the 241-AX Tank Farm at the Hanford Site. For the study, it was assumed that the tanks would each contain $360 \mathrm{ft}^{3}$ of residual waste (corresponding to the one percent residual inventory target cited in the TriParty Agreement) at the time of demolition. The 241-AX Tank Farm is being employed as a "strawman" in engineering studies evaluating clean and landfill closure options for Hanford single-shell tank farms. The report is one of several reports being prepared for use by the Hanford Tanks Initiative Project to explore potential closure options and to develop retrieval performance evaluation criteria for tank farms.

TRADEMARK DISCLAIMER. Reference herein to any specific commercial product, process, or service by trade name, trademark. manufacturer, or otherwise. does not necessarily constitute or imply its endorsement. recommendation. or favoring by the United States Government or any agency thereof or its contractors or subcontractors.

Printed in the United States of America. To obtain copies of this document, contact: Document Control Services. P.O. Box 950 . Mailstop H6-088. Rich and WA Y9352, Phone (5099) 372-2420; Fax (509) 376-4989.
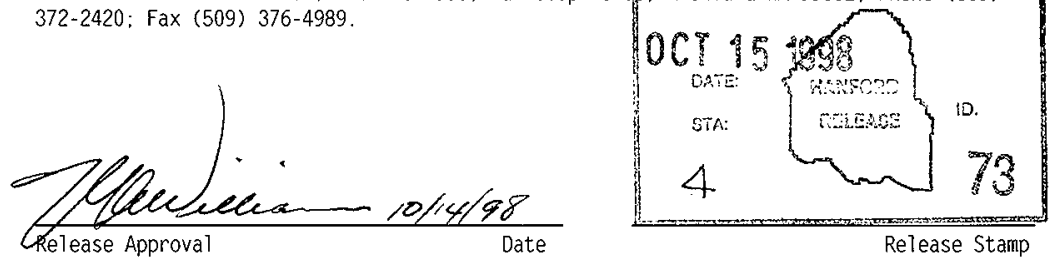

\section{Approved for Public Release}


HNF-3378-Rev. 0

\title{
AX TANK FARM TANK REMOVAL STUDY
}

\author{
W. A. Skelly
}

September 1998

COGEMA Engineering Corporation

P. O. Box 840

Richland, Washington 99352 
HNF-3378-Rev. 0

This page intentionally left blank 
HNF-3378-Rev. 0

\section{CONTENTS}

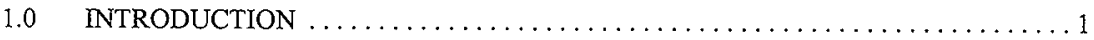

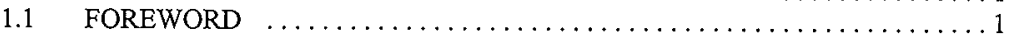

1.2 STUDY SCOPE AND OBJECTIVES $\ldots \ldots \ldots \ldots \ldots \ldots \ldots \ldots \ldots \ldots$

2.0 INFERRED SPATIAL DISTRIBUTION OF VADOSE ZONE CONTAMINATION .. 3

2.1 SUMMARY OF VADOSE ZONE CONTAMINATION WITHIN 241-AX

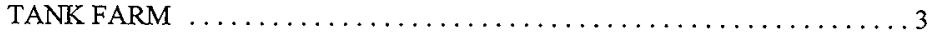

2.2 DESCRIPTIONS OF INDIVIDUAL PLUMES BASED ON ${ }^{137} \mathrm{Cs}$

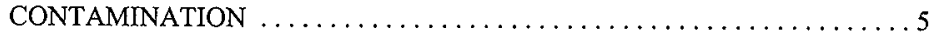

2.3 INFERRED DISTRIBUTION OF TRANSURANIC CONTAMINANTS $\ldots .8$

2.4 PRESUMPTIVE PHYSICAL AND HYDROLOGIC PROPERTIES OF

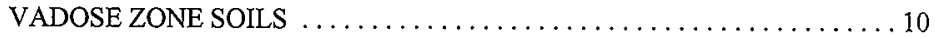

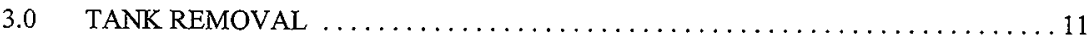

3.1 FUNCTIONAL REQUIREMENTS $\ldots \ldots \ldots \ldots \ldots \ldots \ldots \ldots \ldots \ldots \ldots \ldots$

3.2 REMEDIAL PROCESS SELECTION $\ldots \ldots \ldots \ldots \ldots \ldots \ldots \ldots \ldots \ldots \ldots$

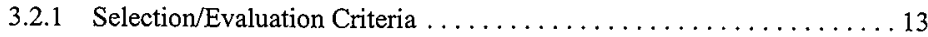

3.2.2 Alternatives Considered for Tank Demolition ................ 14

3.2.3 Evaluation of Individual Alternatives ..................... 15

3.2.4 Related Decommissioning Experience ................. 19

3.3 DESCRIPTION OF PROPOSED TANK REMOVAL CONCEPT $\ldots \ldots \ldots \ldots 20$

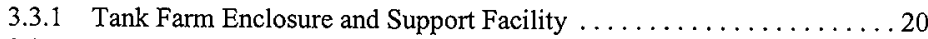

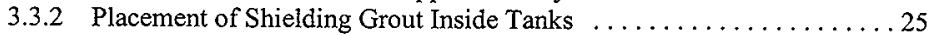

3.3.3 Removal of Cover Soil .......................... 26

3.3.4 Demolition/Removal of Tank Domes ................... 29

3.3.5 Lateral Soil Removal . . . . . . . . . . . . . . . . . . . . . . 30

3.3.6 Demolition of Tank Sidewalls .......................... 33

3.3.7 Base Slab and Footing Ring Removal ................... 34

3.3.8 Backfilling the Excavation After Tank Removal . . . . . . . . . . . 36

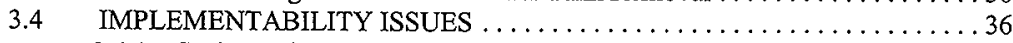

3.4.1 Scaleup of Enclosure Structure Concept $\ldots \ldots \ldots \ldots \ldots \ldots \ldots \ldots . \ldots \ldots$

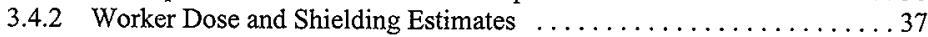

3.4.3 Radionuclides in Air-Suspended Particulates . . . . . . . . . . . . . 37

3.4.4 Worker Health and Safety Considerations ................... 38

3.4.5 Packaging and Disposition of Base Slab Rubble ................. 38

3.4.6 Environmental Restoration Disposal Facility Interface . . . . . . . . . 38

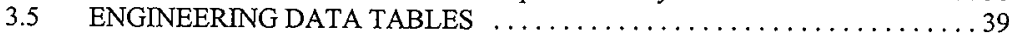

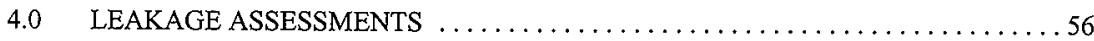


HNF-3378-Rev. 0

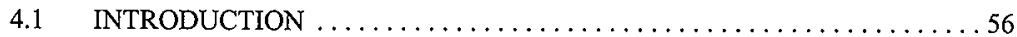

4.2 ESTIMATION OF CONTAMINATED SOIL VOLUMES $\ldots \ldots \ldots \ldots \ldots . . .56$

4.3 CONTAMINANT INVENTORY AND ${ }^{137}$ CESIUM AND ${ }^{90}$ STRONTIUM DISTRIBUTIONS IN LEAKAGE PLUMES ...................5 57

4.4 SCOPING ESTIMATES OF DOSE RATES FROM LEAKAGE PLUMES …59

4.5 WORKER DOSE CONSEQUENCES FROM LEAKAGE SCENARIOS . . . . . 59

4.6 CONSTRUCTIBILITY IMPACTS FROM LEAKAGE SCENARIOS . . . . 62

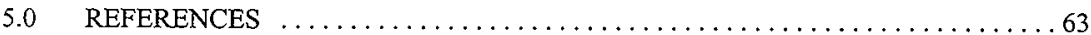

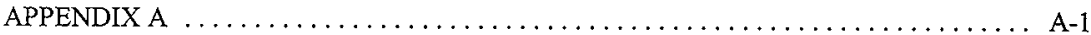

DOSE RATE ESTIMATES FOR AX TANK FARM REMEDIATION $\ldots \ldots \ldots$ A-1

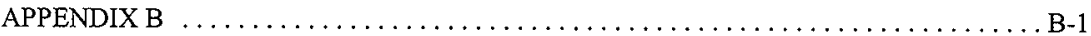

TANK REMOVAL COST ESTIMATE $\ldots \ldots \ldots \ldots \ldots \ldots \ldots \ldots \ldots \ldots$ B-1 


\section{TABLES}

2.1. Estimated Volume of Contaminated Soil in AX Tank Farm ................

2.2 AX Tank Farm Release Radiological Inventory

Contaminant Plumes .8

3.1. Best-Basis Inventories for ${ }^{137} \mathrm{Cs}$ and ${ }^{90} \mathrm{Sr}$

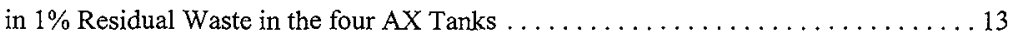

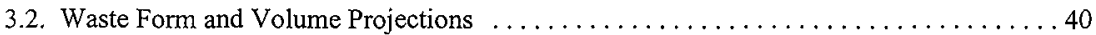

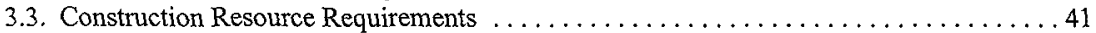

3.3.1. Particulate Emissions Originating Outside of

AX Tank Farm from Activities Associated with Tank Removal . . . . . . . . . . . 44

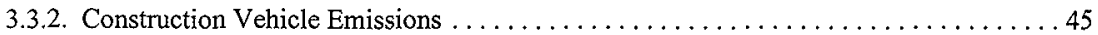

3.3.3. Estimates of Particulate Emissions from

Confinement Structure over AX Tank Farm During Tank Removal . . . . . . . . . 46

3.3.4. Radiological Inventory in Particulate Emissions (Curies) . . . . . . . . . . . . . . 50

3.4. Personnel Requirements ...................................... 51

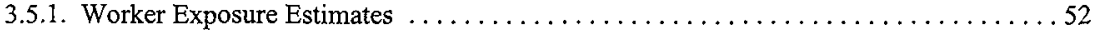

3.5.2. Cumulative Exposure Estimates by Unit Process $\ldots \ldots \ldots \ldots \ldots \ldots \ldots \ldots \ldots \ldots 3$

3.6. Cost Breakdown ....................................... 54

4.1. Total Activities from Various Leakage

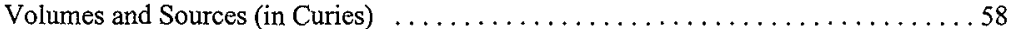

4.2. Surface Soil ${ }^{137} \mathrm{Cs}$ and ${ }^{90} \mathrm{Sr}$ Concentrations $\left(\mathrm{C}_{\mathrm{o}}\right)$

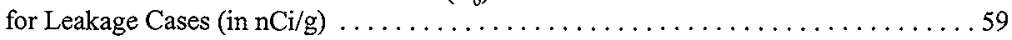

4.3. Estimated Dose Rates 1 meter Above the Center of

Specified Leakage Volumes and Sources (in mrem $/ \mathrm{hr}$ ) . . . . . . . . . . . . . 59

4.4. ROM Estimates of Increases in Local Background

in the Pit Excavation due to Leakage $(\mathrm{mrem} / \mathrm{hr}) \ldots \ldots \ldots \ldots \ldots \ldots \ldots \ldots$

\section{FIGURES}

2.1. AX Tank Farm Site Plan

with Contoured Contamination Plumes $\ldots \ldots \ldots \ldots \ldots \ldots \ldots \ldots \ldots \ldots \ldots$

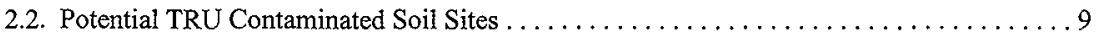

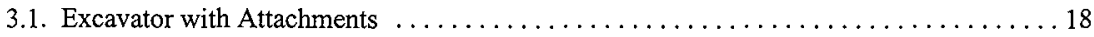

3.2. Plan View of Enclosure

Structure over AX Tank Farm .............................. 22

3.3 Section Views of

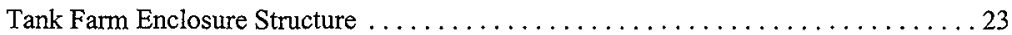

3.4. Pit Excavation After Cover Soil Removal . . . . . . . . . . . . . . . . . . . . 28

3.5. Pit Excavation After Lateral Soil Removal . . . . . . . . . . . . . . . . . . . . . . 31

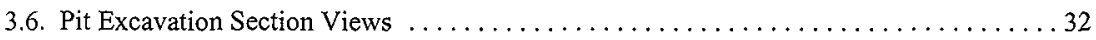


HNF-3378-Rev. 0

\subsection{Pit Excavation with}

Hypothetical Leak Phume Locations

.61 
HNF-3378-Rev. 0

\section{ACRONYMS}

$\begin{array}{ll}\text { CERCLA } & \text { Comprehensive Environmental Response, Compensation and Liability Act } \\ \text { DOE } & \text { U.S. Department of Energy } \\ \text { Ecology } & \text { Washington State Department of Ecology } \\ \text { EPA } & \text { U.S. Environmental Protection Agency } \\ \text { ERDF } & \text { Environmental Restoration Disposal Facility } \\ \text { HEPA } & \text { high-efficiency particulate air } \\ \text { HTI } & \text { Hanford Tanks Initiative } \\ \text { LLW } & \text { low-level waste } \\ \text { MOU } & \text { Memorandum of Understanding } \\ \text { NHC } & \text { Numatec Hanford Corporation } \\ \text { RCRA } & \text { Resource Conservation and Recovery Act } \\ \text { RFP } & \text { request for proposal } \\ \text { RO/RO } & \text { roll-on/roll-off } \\ \text { SOW } & \text { statement of work } \\ \text { SST } & \text { single-shell tank } \\ \text { STRARCH } & \text { stressed arch } \\ \text { Tri-Party } & \\ \text { Agreement } & \text { Hanford Federal Facility Agreement and Consent Order } \\ \text { TRU } & \text { transuranic } \\ \text { TWRS } & \text { Tank Waste Remediation System } \\ \text { WAC } & \text { Washington Administrative Code } \\ \text { WBS } & \text { work breakdown structure }\end{array}$




\section{AX TANK FARM TANK REMOVAL STUDY}

\subsection{INTRODUCTION}

\subsection{FOREWORD}

In May of 1996, the U.S. Department of Energy (DOE) implemented a five-year demonstration project known as the Hanford Tanks Initiative (HTI). The scope of HTI is to (1) demonstrate alternate retrieval technologies for tank waste; (2) retrieve hard-heel waste from tank 241-C-106 and assess compliance with retrieval performance evaluation criteria for that activity; (3) characterize residual waste in Tank 241-AX-104 and assess compliance with retrieval performance criteria for that tank; and (4) develop retrieval performance evaluation criteria supporting readiness to close single-shell tanks (SSTs) in the future. The HTI mission is to minimize technical uncertainties and programmatic risks by conducting demonstrations to characterize and remove tank waste using technologies and methods that will be needed in the future to carry out tank waste remediation and tank farm closure. A detailed description of the entire HTI Project is provided in the Hanford Tanks Initiative Plan, WHC-SD-WM-PMP-022.

The HTI project team is comprised of representatives from the Project Hanford Management Contract (PHMC), Pacific Northwest National Laboratory (PNNL), and private consultants. The team is working closely with Washington State Department of Ecology (Ecology), various northwest stakeholders, and native American tribes to identify and develop waste retrieval performance criteria for subsequent formulation of acceptable closure criteria and standards for tank farms.

In August of 1996, the DOE and Ecology signed a memorandum of understanding (MOU) in which they agreed to collaborate in addressing the issues of "what degree of waste removal should be used as the basis for waste retrieval systems technology development, retrieval systems engineering, and definition of completion of retrieval operations." In preparing the agreement, the two agencies conceded that "it has not been established that 99 percent waste retrieval as defined in the Hanford Federal Facility Agreement and Consent Order (Tri-Party Agreement [TPA]) Milestone M-45-00 will be sufficient to allow closure of tank farms; nor has it been determined that 99 percent retrieval is technically achievable, or represents a performance objective that considers cost, technical practicality, exposure to radiation, and/or Nuclear Regulatory Commission requirements." Conditions of TPA Milestone M-45-00 stipulate that "in evaluating closure options for SSTs, contaminated soil, and ancillary equipment, Ecology and the Environmental Protection Agency (EPA) will consider cost, technical practicality, and potential exposure to radiation" (JEG 1997)

One essential element of the HTI mission is to provide a basis for future National Environmental Policy Act of 1969 (NEPA) safety, and regulatory actions affecting waste retrieval and operable unit closure of the Hanford Site tank farms. This goal is being met by development of retrieval performance criteria, through assessment of risk to human health and environment. Hence, several engineering studies have been conducted to provide the necessary data for evaluation of 
risk to human health and environment. This report, AX Tank Farm Tank Removal Study, describes a methodology for exposing, demolishing, and removal of debris from the four SSTs in the farm. Demonstrating that tank removal is feasible and practical is one of the essential considerations involved in the larger issue of clean closure of tank farms at Hanford. Concepts are developed for performing the work, including descriptions of the layouts, equipment, labor and materials required, and evaluated with respect to cost, technical practicality and worker radiological exposures. Other studies that interact with this study are the AX Tank Farm Ancillary Equipment Study and the Soil Remediation Study.

\subsection{STUDY SCOPE AND OBJECTIVES}

In January of 1997, Numatec Hanford Corporation (NHC) issued a request for proposals (RFP) with a statement of work (SOW) for engineering services to support HTI in evaluating closure alternatives for development of retrieval performance evaluation criteria. Several tasks identified and described in the RFP were assigned to COGEMA Engineering Corporation (COGEMA), the following month. This report documents the results of engineering studies carried out by COGEMA in response to RFP Task 2, "Tank Removal Study." Related work on RFP Task 3, "Soil Remediation Study," is summarized in a separate report.

The SOW for the AX Tank Farm Tank Removal Study directed COGEMA to evaluate alternative approaches and concepts for removing $\mathrm{AX}$ tanks from the ground. For those concepts that are considered to be feasible, COGEMA was to provide conceptual engineering to quantify the technical approach, labor, equipment, materials, cost, and schedule involved. An analysis of worker radiological hazards was requested as well. Finally, the SOW requested an assessment of the impacts on tank removal of either of two scenarios, an 8,000-gal leak or a 40,000-gal leak during waste retrieval.

A directed assumption for the study was that the tanks would contain a residual waste inventory of $360 \mathrm{ft}^{3}$ (i.e., one percent residual inventory) after waste retrieval that would be sufficient to comply with the TPA retrieval objective. The SOW requested documentation for any/all enabling assumptions applied in concept development. Study criteria regarding the chemical and radiological composition of the one percent residual inventory in the tanks were developed by COGEMA under a separate task (Task 4, "Waste Inventory Study").

The 241-AX tank farm is located in the 200 East Area of the Hanford Site. The farm contains four 100-Series (1 million gal capacity) tanks, each with a 75-ft inside diameter, 45.75- $\mathrm{ft}$ height measured from the top of the footings to the top of the dome, and a minimum $6 \mathrm{ft}$ of soil cover. The AX farm was the last of 12 SST farms to be built at Hanford. The farm was constructed in 1963 to 1964, and individual tanks went into service in early 1965. The AX tanks were constructed to what was termed the "fifth generation" design. They were designed to receive and store Plutonium Uranium Extraction (PUREX) Plant and B Plant aging wastes that exhibited self-boiling and self-concentrating properties for periods of five to 10 years. Unique features of the fifth generation design included a grid of drain slots (used for leak detection) cast into the base slab of each tank, a 3/8-in carbon steel liner (earlier tanks had 1/4-in liners), elimination of cascade (overflow) lines between tanks, and an integral system of airlift circulators. 
The 241-AX tank farm was designated in the RFP/SOW as the "strawman" to be evaluated in Task 3 and related engineering studies. Identification of AX farm for these studies was based on the understanding that it is likely to be designated by the DOE as the first tank farm to undergo closure consistent with TPA milestones in 2004 ("Submit Closure Plan for Selected Tank Farm"), 2012 ("Initiate Closure of Selected Tank Farm"), and 2014 ("Complete Closure of Selected Tank Farm"). While the AX tank farm is the smallest of the 12 SST farms at the Hanford Site, the AX tanks pose some of the greatest challanges for waste characterization, retrieval, and closure due to their dimensions, the configuration of in-tank hardware, the residual waste compositions, and the concentration of associated external ancillary equipment. Additionally, the 241-AX tank farm contains one tank (AX-104) that was sluiced extensively in the past and is currently empty except for a minimal volume of hard-heel waste residue. The HTI team plans to utilize this tank for deployment and demonstration of in-tank characterization technologies and for evaluation of performance objectives for retrieval and closure.

\subsection{INFERRED SPATIAL DISTRIBUTION OF VADOSE ZONE CONTAMINATION}

\subsection{SUMMARY OF VADOSE ZONE CONTAMINATION WITHIN 241-AX TANK FARM}

The report entitled Report of Best-Estimate Past Release Vadose Zone Contamination of the 241-AX Tank Farm (CEES 1997) provides an evaluation of the nature and extent of vadose zone contamination that has occurred during operations of the 241- AX tank farm. This report constitutes a best estimate of vadose zone contamination from past releases of chemical and radiological waste contaminants. This estimate was developed from information on the source, timing, nature, extent, and composition of the contaminant streams identified from available transfer data and operations logs. The evaluation included reviews of historical and recent reports of gamma logs taken in the 32 dry wells that monitor potential leakage from the tanks. Sources of gross gamma log data included original well logs plus two recent summary reports (DOE 1992 and DOE/GJO 1997).

The isotope ${ }^{137} \mathrm{Cs}$ is the principal radionuclide that is detected in borehole logging in the 200 Areas and is, therefore, most useful for evaluating vadose zone contamination associated with past leaks and/or spills. Six primary release zones ("plumes") that have been identified and correlated with specific tanks and specific material compositions are represented in Figure 2.1 together with seven secondary ${ }^{137} \mathrm{Cs}$ releases. The available information does not indicate leakage from any of the four SSTs in the farm, but there is much evidence indicating that significant releases have occurred at and near the surface of the tank farm from spills, transfer lines, and tank ancillary equipment, particularly the tank vent headers. Since no characterization data are available concerning physical and hydraulic properties of the soils at the site, the radiochemistry and composition of the zones of contamination were used as indicators of migration to the depths indicated by gamma-emitters measured in each dry well.

The maximum estimated depth of migration for ${ }^{137} \mathrm{Cs}$ contamination in Figure 2.1 is approximately $25.9 \mathrm{~m}(85 \mathrm{ft})$. The maximum measured concentration of ${ }^{137} \mathrm{Cs}$ in AX Tank Farm soils is approximately $4 \mathrm{nCi} / \mathrm{g}$. 
Figure 2.1. AX Tank Farm Site Plan with Contoured Contamination Plumes

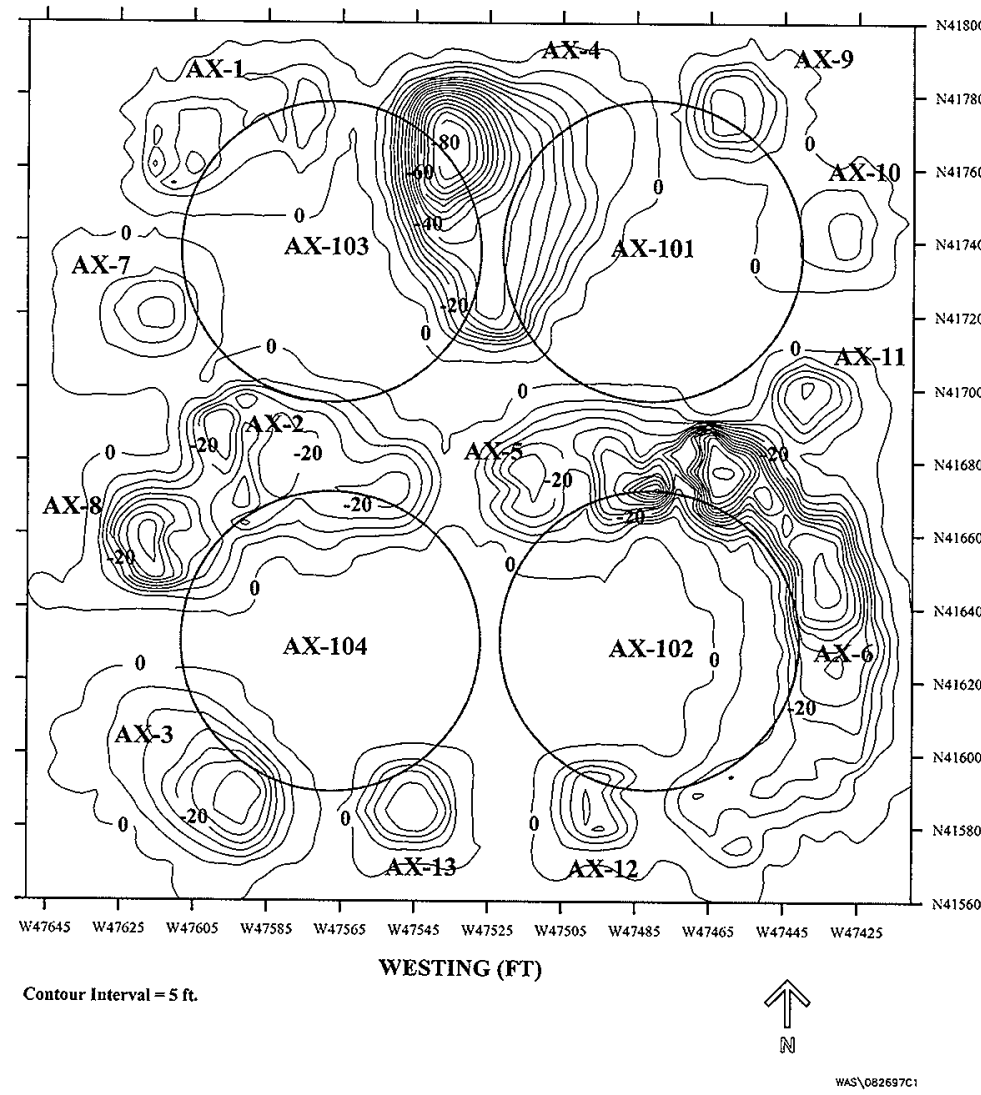

$\frac{\sum}{z}$ 


\subsection{DESCRIPTIONS OF INDIVIDUAL PLUMES BASED ON ${ }^{137} \mathrm{Cs}$ CONTAMINATION}

The extent of vadose zone contamination within the 241-AX Tank Farm consists of the 13 individual contaminated soil sites ("plumes") shown in Figure 2.1. Volume estimates of the contaminated soil in each plume are provided in Table 2.1. Each plume is briefly described below:

- $\quad \mathbf{A X}-\mathbf{1}$ (northwest of Tank AX-103):

${ }^{137} \mathrm{Cs}$ contamination is indicated to depths of approximately $6.1 \mathrm{~m}(20 \mathrm{ft})$. The maximum measured concentration of ${ }^{137} \mathrm{Cs}$ was approximately $40 \mathrm{pCi} / \mathrm{g}$.

- AX-2 (immediately north and northwest of Tank AX-104):

${ }^{137} \mathrm{Cs}$ contamination indicated to depths of approximately $12 \mathrm{~m}(40 \mathrm{ft})$. The maximum measured concentration of ${ }^{137} \mathrm{Cs}$ was $100 \mathrm{pCi} / \mathrm{g}$.

- AX-3 (adjacent to and southwest of Tank AX-104):

${ }^{137} \mathrm{Cs}$ contamination is indicated to depths of approximately $21 \mathrm{~m}$ (70 ft). The maximum measured concentration of ${ }^{137} \mathrm{Cs}$ is approximately $34 \mathrm{pCi} / \mathrm{g}$.

- AX-4 (northeast of Tank AX-104 and northwest of Tank AX-101):

${ }^{137} \mathrm{Cs}$ contamination is indicated to depths of approximately $25.6 \mathrm{~m}(84 \mathrm{ft})$. The maximum measured concentration of ${ }^{137} \mathrm{Cs}$ is approximately $4,000 \mathrm{pCi} / \mathrm{g}$.

- AX-5 (immediately north and northwest of Tank AX-102):

${ }^{137} \mathrm{Cs}$ contamination is identified to depths of approximately $12 \mathrm{~m}(40 \mathrm{ft})$. The maximum measured concentration of ${ }^{137} \mathrm{Cs}$ is approximately $417.8 \mathrm{pCi} / \mathrm{g}$.

- $\quad \mathbf{A X}-6$ (northeast and east of Tank AX-102):

${ }^{137} \mathrm{Cs}$ contamination is indicated to a depths of approximately $22.9 \mathrm{~m} \mathrm{(75} \mathrm{ft).} \mathrm{The}$ maximum measured concentration of ${ }^{137} \mathrm{Cs}$ is approximately $15.8 \mathrm{pCi} / \mathrm{g}$.

The remaining zones of contamination, $\mathrm{AX}-7$ through $\mathrm{AX}-13$, are generally shallow, secondary features, many of which will be eliminated in the process of excavating soil for tank removal.

- $\quad \mathbf{A X}-7$ (west-southwest of Tank AX-103):

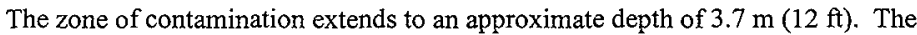
maximum measured concentration of ${ }^{137} \mathrm{Cs}$ is $7.5 \mathrm{pCi} / \mathrm{g}$. 
- AX-8 (west-northwest of Tank AX-104):

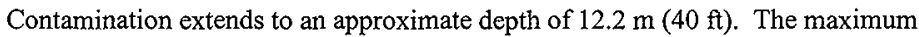
measured concentration of ${ }^{137} \mathrm{Cs}$ is $1,456 \mathrm{pCi} / \mathrm{g}$.

- AX-9 (adjacent to Tank AX-101 to the northeast):

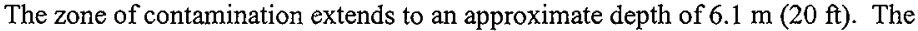
maximum measured concentration of ${ }^{137} \mathrm{Cs}$ is $8 \mathrm{pCi} / \mathrm{g}$.

AX-10 (east of Tank AX-101):

The zone of contamination extends to an approximate depth of $3 \mathrm{~m}(10 \mathrm{ft})$. The maximum measured concentration of ${ }^{137} \mathrm{Cs}$ is $6 \mathrm{pCi} / \mathrm{g}$.

- $\quad \mathbf{A X}-11$ (southeast of Tank AX-101 and northeast of Tank AX-102):

The zone of contamination extends to an approximate depth of $7.6 \mathrm{~m}(25 \mathrm{ft})$. The maximum measured concentration of ${ }^{137} \mathrm{Cs}$ is approximately $51.5 \mathrm{pCi} / \mathrm{g}$.

- AX-12 (south of Tank AX-102):

The zone of contamination extends to an approximate depth of $6.1 \mathrm{~m}(20 \mathrm{ft})$. The maximum measured concentration of ${ }^{137} \mathrm{Cs}$ is approximately $13 \mathrm{pCi} / \mathrm{g}$.

- $\quad \mathbf{A X}-13$ (southeast of Tank AX-104):

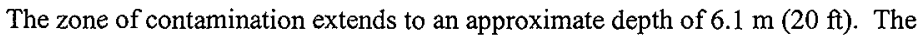
maximum measured concentration of ${ }^{137} \mathrm{Cs}$ is approximately $9.8 \mathrm{pCi} / \mathrm{g}$. 
Table 2.1. Estimated Volume of Contaminated Soil in AX Tank Farm

\begin{tabular}{|l|l|l|l|l|}
\hline \multirow{2}{*}{ Contaminant Plume } & \multicolumn{2}{|c|}{ Estimated Volume } & \multicolumn{2}{c|}{ Estimated Volume (X2) } \\
\cline { 2 - 5 } & \multicolumn{1}{|c|}{$($ liter) } & \multicolumn{1}{c|}{$\left(\mathrm{yd}^{3}\right)$} & \multicolumn{1}{c|}{ (liter) } & \multicolumn{1}{c|}{$\left(\mathrm{yd}^{3}\right)$} \\
\hline AX-1 & $5.34 \mathrm{E}+05$ & $6.99 \mathrm{E}+02$ & $1.07 \mathrm{E}+06$ & $1.40 \mathrm{E}+03$ \\
\hline AX-2 & $1.22 \mathrm{E}+06$ & $1.60 \mathrm{E}+03$ & $2.44 \mathrm{E}+06$ & $3.19 \mathrm{E}+03$ \\
\hline AX-3 & $8.02 \mathrm{E}+05$ & $1.05 \mathrm{E}+03$ & $1.60 \mathrm{E}+06$ & $2.10 \mathrm{E}+03$ \\
\hline AX-4 & $3.46 \mathrm{E}+06$ & $4.53 \mathrm{E}+03$ & $6.92 \mathrm{E}+06$ & $9.05 \mathrm{E}+03$ \\
\hline AX-5 & $1.10 \mathrm{E}+06$ & $1.44 \mathrm{E}+03$ & $2.20 \mathrm{E}+06$ & $2.88 \mathrm{E}+03$ \\
\hline AX-6 & $3.36 \mathrm{E}+06$ & $4.40 \mathrm{E}+03$ & $6.73 \mathrm{E}+06$ & $8.80 \mathrm{E}+03$ \\
\hline AX-7 & $2.17 \mathrm{E}+05$ & $2.84 \mathrm{E}+02$ & $4.35 \mathrm{E}+05$ & $5.68 \mathrm{E}+02$ \\
\hline AX-8 & $6.79 \mathrm{E}+05$ & $8.88 \mathrm{E}+02$ & $1.36 \mathrm{E}+06$ & $1.78 \mathrm{E}+03$ \\
\hline AX-9 & $2.57 \mathrm{E}+05$ & $3.36 \mathrm{E}+02$ & $5.14 \mathrm{E}+05$ & $6.72 \mathrm{E}+02$ \\
\hline AX-10 & $1.22 \mathrm{E}+05$ & $1.59 \mathrm{E}+02$ & $2.43 \mathrm{E}+05$ & $3.18 \mathrm{E}+02$ \\
\hline AX-11 & $2.11 \mathrm{E}+05$ & $2.75 \mathrm{E}+02$ & $4.21 \mathrm{E}+05$ & $5.51 \mathrm{E}+02$ \\
\hline AX-12 & $2.20 \mathrm{E}+05$ & $2.88 \mathrm{E}+02$ & $4.40 \mathrm{E}+05$ & $5.76 \mathrm{E}+02$ \\
\hline AX-13 & $2.43 \mathrm{E}+05$ & $3.18 \mathrm{E}+02$ & $4.86 \mathrm{E}+05$ & $6.36 \mathrm{E}+02$ \\
\hline Estimated Total & $1.24 \mathrm{E}+07$ & $1.63 \mathrm{E}+04$ & $2.49 \mathrm{E}+07$ & $3.25 \mathrm{E}+04$ \\
\hline
\end{tabular}




\subsection{INFERRED DISTRIBUTION OF TRANSURANIC CONTAMINANTS}

An evaluation was performed of the radiological inventory of the tanks and the release inventory of the zones of contamination to determine which transuranic (TRU) contaminants were released and their total estimated concentrations. The TRU contaminants associated with these releases are ${ }^{237} \mathrm{Pu},{ }^{23} \mathrm{~Np},{ }^{240} \mathrm{Pu},{ }^{241} \mathrm{Am},{ }^{242} \mathrm{mAm},{ }^{243} \mathrm{Am}$, and ${ }^{243} \mathrm{Cm}$. The associated inventories are listed in Table 2.2. Further analysis was performed to determine if these inventories could exceed the 100 $\mathrm{nCi} / \mathrm{g}$ concentration threshold in soil. Three potential zones of TRU soil contamination were identified: AX-2, AX-4, and AX- 6 . The mobility of all TRU contaminants identified above is low with the exception of ${ }^{237} \mathrm{~Np}$. At all three sites, transuranics are expected to be concentrated in restricted central areas of the plumes within the upper three meters $(10 \mathrm{ft}$ ) of fill (see Figure 2.2). These potential TRU zones would all be eliminated in the process of removing soil to expose the tanks.

Table 2.2 AX Tank Farm Release Radiological Inventory Contaminant Plumes

\begin{tabular}{||c|c|c|c||}
\hline Transuranics & AX-2 (Ci) & AX-4 (Ci) & AX-6 (Ci) \\
\hline${ }^{237} \mathrm{~Np}$ & $9.66 \mathrm{E}-03$ & $6.52 \mathrm{E}-06$ & $6.11 \mathrm{E}-04$ \\
${ }^{238} \mathrm{Pu}$ & $7.29 \mathrm{E}-03$ & $4.92 \mathrm{E}-06$ & $2.13 \mathrm{E}-06$ \\
${ }^{240} \mathrm{Pu}$ & $3.60 \mathrm{E}-02$ & $2.43 \mathrm{E}-05$ & $5.18 \mathrm{E}-06$ \\
${ }^{241} \mathrm{Am}$ & $6.49 \mathrm{E}-01$ & $4.38 \mathrm{E}-04$ & $5.19 \mathrm{E}-05$ \\
${ }^{243} \mathrm{mAm}$ & NR & NR & NR \\
${ }^{243} \mathrm{Am}$ & $1.99 \mathrm{E}-05$ & $1.34 \mathrm{E}-08$ & $9.28 \mathrm{E}-05$ \\
& $2.22 \mathrm{E}-04$ & $1.50 \mathrm{E}-07$ & $5.80 \mathrm{E}-09$ \\
& & & \\
Estimated Total & & & \\
TRU (Ci) & $7.02 \mathrm{E}-01$ & $4.74 \mathrm{E}-04$ & $7.63 \mathrm{E}-04$ \\
\hline
\end{tabular}


HNF-3378-Rev. 0

Figure 2.2. Potential TRU Contaminated Soil Sites

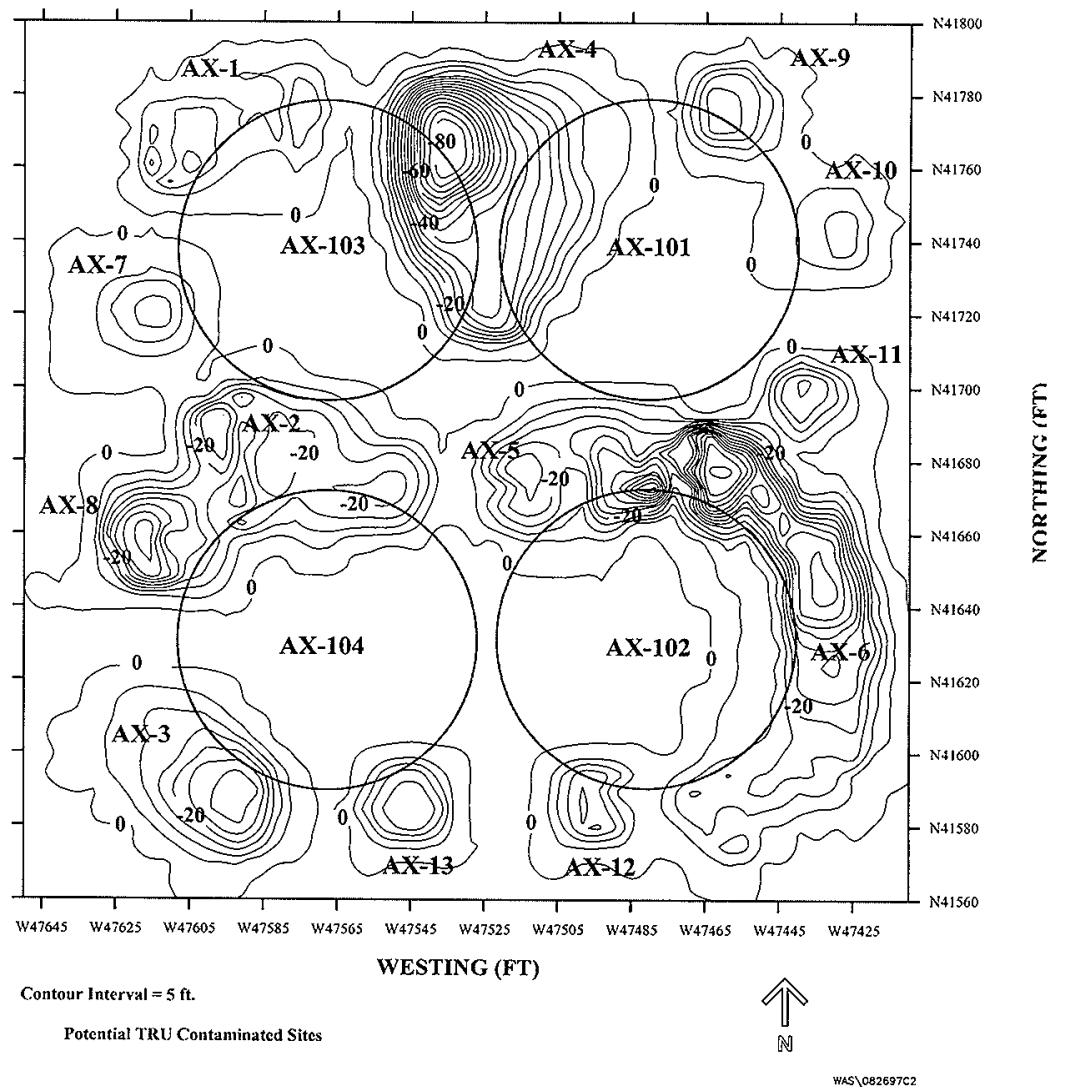




\subsection{PRESUMPTIVE PHYSICAL AND HYDROLOGIC PROPERTIES OF VADOSE ZONE SOILS}

The stratigraphy underlying the 241-AX tank farm has been described and reported by numerous investigators (Price and Fecht 1976, Caggiano and Goodwin 1991, Lindsey and Law 1993). The 241-AX tank farm is underlain by three major stratigraphic units:

- Unconsolidated sand, silt, and gravel of the Hanford formation,

- Semiconsolidated sediments of the Ringold Formation, and

- Basalt flows of the Columbia River Group that form the bedrock beneath the tank farm area. From the ground surface to the base of the tanks, a depth of approximately $16.8 \mathrm{~m}$ $(55 \mathrm{ft})$ is compacted backfill material of excavated Hanford formation.

The Hanford formation is subdivided into two units identified as $\mathrm{H} 1$ and $\mathrm{H} 2$, which make up the vadose zone sediments underlying the AX tank farm. Unit $\mathrm{H} 1$ occurs from zero to $15 \mathrm{~m}$ (0 to 50 $\mathrm{ft}$ ) below the base of the tanks and consists of a westward thinning sequence of slightly silty, pebbly, very coarse to coarse sand and sandy, fine to very fine pebble gravel to pebbly, very coarse sand (Price and Fecht 1976). There is no direct evidence of clay-rich or silt-rich horizons within this unit. The absence of horizons of fine-textured material suggests that there is a limited potential for contaminant plume spreading at the contact of a silt interface. The potential does exist for encountering zones of higher moisture content where hydrologic breaks occur in the stratigraphic section.

Unit $\mathrm{H} 1$ is underlain by approximately 35 to $46 \mathrm{~m}$ (114 to $151 \mathrm{ft})$ of slightly silty, very coarse to medium sand (Price and Fecht 1976) assigned to unit H2. Unit H2 is interpreted to be dominated by well stratified sand typical of the sand-dominated facies (Piepho et al. 1996).

In general, the site soils are expected to exhibit the following physical characteristics:

\section{- Porosity}

The porosity, or saturated moisture content, was assumed to range from 35 to 42 percent depending on which specific soil type was referenced. The values selected for this study for the Hanford formation sandy sequence, the Hanford formation gravel sequence, and the backfill soil are 42,35 , and 37 percent, respectively.

\section{- Soil Moisture Content}

The residual soil moisture content was assumed to range from two to 4.5 percent. Values for the Hanford formation sandy sequence, the Hanford formation gravel sequence, and backfill are two percent, two percent, and 4.5 percent, respectively. 
The hydraulic conductivity, $\mathrm{K}$, was assumed to range from $2.73 \mathrm{E}-04$ to $3.00 \mathrm{E}-02 \mathrm{~cm} / \mathrm{sec}$. The values selected for hydraulic conductivities of Hanford formation sandy sequence, Hanford formation gravel sequence, and backfill are 1.55E-03, 2.73E-04, and 3.00E-02 $\mathrm{cm} / \mathrm{sec}$, respectively.

\section{- Friction Angle, Cohesion, Bulk Density}

The following presumptive physical properties values were used in sample calculations of ground support requirements for the excavation scenarios described in Section 3.0.

The angle of internal friction was assumed to equal 42 degrees, cohesion to equal zero, and in-place bulk density to equal $140 \mathrm{lbs} / \mathrm{ft}^{3}$.

\subsection{TANK REMOVAL}

\subsection{FUNCTIONAL REQUIREMENTS}

A practical concept is required that will enable individual tanks in the 241-AX tank farm to be physically accessed and removed. Gaining access to the tanks will require excavation of soil from above and around the tanks down to the level of the footings. Based on the information presented in Section 2.0, the soil column from the surface to the tank footing level (i.e., from depths of zero to approximately $52 \mathrm{ft}$ ) contains extensive radiological and chemical contamination, with localized ${ }^{137} \mathrm{Cs}$ concentrations of up to $4 \mathrm{nCi} / \mathrm{g}$, and the potential for encountering isolated small pockets of soil with transuranic concentrations exceeding $100 \mathrm{nCi} / \mathrm{g}$. The evidence summarized in Section 2.0 indicates that soil contamination in the 24l-AX tank farm has originated from numerous separate surface spills and leaks from transfer piping and ancillary equipment originating at shallow depths in the soil, rather than from any of the tanks themselves. Based on this information, a workable concept for tank removal must include, as an element, a concept for removing soil from above and around the tanks that provides for adequate worker protection, dust control, and physical isolation of the site.

The tank removal concept must include, as a second element, a workable concept for tank demolition. The four SSTs in the 241-AX tank farm are one-million-gal tanks, with nominal 75$\mathrm{ft}$ diameters. The outside height of the tanks measured at the sidewall (i.e., from the top of the footing to the comer of the haunch) is approximately $38 \mathrm{ft}$. The inside height at the centerline is $44.5 \mathrm{ft}$. The tank domes vary in thickness from a minimum thickness of $15 \mathrm{in}$. at the center to a maximum of about $4 \mathrm{ft}$ at the haunch. In the center-span area of the dome, radial and circular bars are No. 6 . Circular bars are on one-foot spacings. Spacing varies for the radial bars; the closest spacing is about six inches at the haunch corner. In the haunch area, circular bars are larger (No. 9 and No. 11) and they are on closer centers (9.0 and 7.5 in. respectively). The tank sidewalls are $15 \mathrm{in}$. thick at the top and two $\mathrm{ft}$ thick at the base. Sidewall reinforcement consists of No. 8 longitudinal bars with a five-inch vertical spacing and vertical bars on about six-inch centers that were variously specified as No. 7,8 , and 9 , depending on the vertical position. The 
footing ring is three $\mathrm{ft}$ thick, the interior area of the base slab is $18 \mathrm{in}$. thick. The reinforcement plan for the base slab is similar to the central area of the dome, with No. 6 radial and circular bars. Radial bars in the footing ring are No. 8 , and No. 8 dowels were used at the joint between the footing ring and the base slab. (For additional details on concrete reinforcement, refer to drawings H-2-44562 and H-2-44565.) The tanks have 3/8-in. carbon steel liners.

From this description, it is understood that the AX tanks are heavily reinforced concrete structures. Therefore, in evaluating different candidate demolition techniques for potential applicability to demolition of SSTs, additional functional requirements are that (a) the method must be able to fracture concrete containing imbedded reinforcing bar, and (b) the method must provide the capability to sever metal (reinforcing bar and liner plate).

The presence of the one percent residual waste inventories in the tanks imposes severe constraints on concept development. Even after most of the tank waste has been removed, the residual inventory represents an extraordinarily hostile environment for any type of manned activity. Best-basis estimates of ${ }^{137} \mathrm{Cs}$ and ${ }^{90} \mathrm{Sr}$ in one percent residual inventories for the four $\mathrm{AX}$ tanks are listed in Table 3.1. Strategies must be incorporated into conceptualization that minimize or eliminate both external (direct exposure) and internal (ingestion/respiration) doses for demolition workers and support personnel. The functional requirement or "standard of practicality" in this instance is to demonstrate with worker dose estimates that tanks can be demolished and all debris can be loaded out and removed from the site (with appropriate time, distance, and shielding provisions) in a manner that will enable worker doses to be maintained within acceptable limits. From discussions with Hanford radiological engineering personnel and the administrative control levels listed in Table H2-1 of the Hanford Site Radiological Control Manual (HSRCM, 1994), a maximum whole body dose of $1,500 \mathrm{mrem} / \mathrm{yr}$ was adopted as the exposure limit criterion for this study. This limit has been imposed on remedial activities at 100 $\mathrm{K}$-Basins, which is the closest actual analog to the work contemplated in this study. It is unlikely that tank removal would qualify for consideration under any of the exceptional situations identified in the manual (i.e., for emergency exposures or planned special exposures) for which DOE might authorize higher limits.

Table 3.1. Best-Basis Inventories for ${ }^{137} \mathrm{Cs}$ and ${ }^{90} \mathrm{Sr}$ in $1 \%$ Residual Waste in the four $\mathrm{AX}$ Tanks

\begin{tabular}{|c||c|c|}
\hline Tank & ${ }^{137} \mathrm{Cs}(\mathrm{Ci})$ & ${ }^{90} \mathrm{Sr}(\mathrm{Ci})$ \\
\hline \hline $\mathrm{AX}-101$ & $5.16 \mathrm{E} 3$ & $1.15 \mathrm{E} 5$ \\
\hline $\mathrm{AX}-102$ & $7.17 \mathrm{E} 3$ & $5.19 \mathrm{E} 4$ \\
\hline $\mathrm{AX}-103$ & $1.09 \mathrm{E} 4$ & $5.25 \mathrm{E} 5$ \\
\hline $\mathrm{AX}-104$ & $1.09 \mathrm{E} 4$ & $5.25 \mathrm{E} 5$ \\
\hline
\end{tabular}

DOE Order 6430.1A, General Design Criteria, imposes functional requirements for containment of radiological releases and positive ventilation control of temporary facilities. The containment requirement in the Order is the basis for proposing to construct an enclosure structure over the 
tank farm as an essential element of the tank removal concept. From a logistical standpoint, the practicality of tank removal (i.e., soil excavation and tank demolition activities) would be severely diminished if footings and structural supports for the enclosure structure were to be placed inside the footprint of the excavation. It is considered essential to overall concept practicality to be able to demonstrate that the enclosure can be designed as a free-span structure with all structural loads bearing at the perimeter of the site.

\subsection{REMEDIAL PROCESS SELECTION}

\subsubsection{Selection/Evaluation Criteria}

Candidate demolition methods were evaluated relative to a number of generalized criteria. The principal criteria applied in the evaluation are summarized below.

- Capability to rubblize thick, heavily reinforced concrete structures and to cut up any included metal

- Workability inside confinement structure

- Worker protection: may be accomplished either by isolating workers in a controllable environment or by providing some degree of remote operation

- Overall productivity and cost.

Based on the description of tank construction, it is apparent that the selected method must be capable of rubblizing concrete with heavy reinforcement (in terms both of the spacing and sizes of the rebar involved). Certain portions of the tanks, notably the haunch and the footing ring, may be particularly difficult to demolish because of the thicknesses of concrete involved. An essential consideration was whether a given method was capable of cutting apart a reinforcing bar. Cutting rebar will be essential in order for large fragments of rubble to be physically separated and size-reduced to facilitate loading out and removing of material from the site. It would also be highly advantageous if the selected method provided the capability to cut up the liner plate into small pieces so that material from the liner could be processed with other types of debris.

Evaluation of demolition methods and selection of the optimal method for tank removal were completed before the enclosure structure concept had been developed. Consequently, specific constraints traceable to the enclosure were not imposed on the selection process. However, in a general sense it was understood that any demolition method requiring large mobile equipment items (e.g., large boom cranes) would be difficult to accommodate. Attempting to work inside an enclosure structure with large mobile cranes would create logistical problems such as (1) moving these items in and out of the enclosure without temporary loss of containment and, (2) maintaining adequate clearances (i.e., head room and swing room) for the equipment to work inside the structure without adding significantly to the size of the structure. Another consideration was that an increasingly substantial enclosure structure would be necessary if the 
selected demolition method required the building to be equipped with any large fixed crane (e.g., a bridge crane).

For unique reasons, some alternatives may not be practical to carry out inside an enclosure or in a radiological environment. For example, explosive demolition methods generate high-velocity fragments and large amounts of air-suspended particulates. Containment of dust is essential if the dust carries radiological contaminants. However, high-velocity fragments from blasting could damage the containment structure and/or elements of its ventilation system.

In consideration of the radiological environment, there is a preference for demolition methods offering high productivities (i.e., high mass reduction per unit time) because of the inherent benefit of minimizing worker exposures in terms of time. Depending on maturity and availability, technologies would be preferred that are readily adaptable to remote operation or robotics (removing workers from the high dose rate environment), or to supplemental shielding strategies (e.g., shielding mobile equipment cabs).

Lastly, there is the criterion of cost. Other considerations being equal, the preferred method is the one that would enable the work to be done at the lowest cost.

\subsubsection{Alternatives Considered for Tank Demolition}

A review of the literature was undertaken to identify potentially applicable demolition methods for the tank removal application. A second objective was to locate case studies of other demolition projects involving radiological issues to determine which demolition methods had been used and what degree of success had been achieved in each case. Two of the references reviewed specifically address decommissioning, decontamination, and demolition of concrete and metal structures in radiological environments (DOE 1980, IAEA 1988). Candidate methods identified in these references and other sources are listed below:

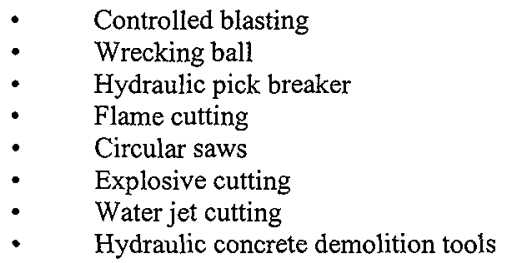

\subsubsection{Evaluation of Individual Alternatives}

3.2.3.1 Alternatives rejected in preliminary screening. The following techniques were rejected during the screening process, for the reasons noted below:

- Controlled blasting: The process consists of drilling holes in concrete, loading them with explosives, and detonating them in a controlled sequence (DOE 1980). This technique is most applicable to thick $(>2 \mathrm{ft}$ ), heavily reinforced concrete. Controlled blasting does not sever rebar. Vibrations, high-velocity particles and dust production associated with this method make it poorly suited to applications 
inside an enclosure. This technique is relatively labor-intensive and materialsintensive, and equipment and materials costs are relatively high. The method is not amenable to remote operations or robotics adaptations.

- Explosive cutting: This method employs placement of shape charges onto the outside surface of a reinforced concrete structure. These charges send a directed shock wave into the material upon detonation. Unlike controlled blasting, this technique cuts rebar as well as concrete. Many of the same arguments against applications of controlled blasting in an enclosure structure would also apply to this method. This technique is relatively labor-intensive and materials-intensive, and equipment and materials costs are relatively high. Placement of explosives, initiators, and blasting lines is not adaptable to remote operations.

- Flame cutting (thermic lance): A thermite reaction process is employed. The equipment consists of a thermite lance (a long iron pipe packed with thermite reagent), which is connected to a continuous source of oxygen gas. Thermite is a mixture of ferric oxide and powdered aluminum. Upon ignition, this combination burns at a temperature of about $2,200^{\circ} \mathrm{C}$. With supplied oxygen, combustion temperatures can reach $5,000^{\circ} \mathrm{C}$. The lance usually is mounted on some type of frame support structure that maintains the orientation of the lance to the work surface. The thermic lance produces large quantities of thick smoke, which makes it difficult to maintain visual control of the operation. The lance is consumed at a rate of one to two $\mathrm{ft} / \mathrm{min}$, making frequent replacement necessary. The technique appears to be labor intensive, and bulk removal rates are low. The technique does not appear to be adaptable to remote operation.

- Wrecking ball: This technique has a long history of use in nonradiological applications. It is capable of rubblizing lightly reinforced concrete structures, but a supplemental method must be provided for severing rebar. Although productivity is high and costs are relatively low, the method is not recommended for radiological situations (DOE 1980).

- Circular saws: On a prototype basis, large circular saws with diamond or tungsten carbide blades have been mounted on the end of a telescoping boom for concrete demolition work. These saws can cut through rebar, but rebar tends to dislodge the abrasive materials, accelerating blade wear. Water must be provided for lubrication. Experience with prototypes appears to be mixed. Relative productivity is low to moderate. Labor and materials costs are expected to be relatively high.

3.2.3.2 Potentially Feasible Alternative. The following demolition methods were all considered to be feasible in initial screening, although differences were apparent from the outset in terms of relative practicality:

- Water jet cutting: This technology has undergone extensive development within the past 20 years. Cutting is done by a jet of water expelled under very high pressure from a small-diameter nozzle. The technology has been adapted to a 
wide variety of industrial applications, most of which are remote operations. Water jets can cut concrete to thicknesses of three ft or more and can cut rebax assisted by abrasive solids. Productivity and costs are moderate.

- Hydraulic concrete demolition implements: Hydraulic-operated cutting and crushing implements are available that can be mounted on the boom of a large backhoe or hydraulic excavator for concrete demolition work. One implement is a hydraulic pick breaker. The pick breaker is a hydraulic-operated impact ram with a moll or chisel point. The ram applies up to $600 \mathrm{high}$-impact blows per minute to a concrete surface. Pick breakers are available in a wide range of sizes and input energy ratings. A second implement is a concrete pulverizer jaw, which is capable of closing on reinforced concrete slabs up to two ft thick, crushing the concrete into small fragments that fall away from the reinforcing steel. A third implement is a shear jaw, which is designed to cut through reinforced concrete panels, reinforcing bar, and steel plate. These implements are designed to be fully interchangeable on a single carrier. They may be used in sequence or independently, depending on the application. Demolition with hydraulic tools is well suited for demolition of heavily reinforced concrete structures and it is well suited to working in interior areas. Productivity is relatively high and costs are expected to be low relative to other feasible methods.

3.2.3.3 Selected method - hydraulic concrete demolition implements. The selected method for tank demolition is to use hydraulic concrete demolition implements mounted on hydraulic excavator carriers. The 241-AX tank farm enclosure structure (described in Section 3.3.1) will provide adequate clearances for excavator operation and the implements themselves pose no specific limitations with respect to indoor operation. This equipment is specifically designed for high productivity and low-cost operation in demolishing heavily reinforced concrete structures. The technology is proven and commercially available.

Two hydraulic excavators will be required. It is envisioned that much of the tank demolition work will be done with the two units working together. Conceptualization was based on handbook data for a Caterpillar 375 excavator. A number of different boom configurations are available for this unit. However, most configurations provide a 35 - to $40-\mathrm{ft}$ reach capability, which is adequate for this project. The width dimension of this excavator is approximately $11.5 \mathrm{ft}$; operating weight is approximately $170,000 \mathrm{lb}$. An excavator in this size range is not so large that it would be unable to work in between the tanks.

Conceptualization of the demolition implements is based on vendor data for LaBounty Manufacturing Model UP-70 concrete pulverizer and shear jaw sets and Stanley Model MB-5950 hydraulic impact breaker. These implements mount in place of the bucket and are operated with the bucket controls and hydraulic systems. The mounting arrangement and the individual implements are shown in Figure 3.1.

Hydraulic demolition implements have not been used in a highly radiological setting before. Some amount of equipment development/modification work will be required to apply the technology to tank removal. Based on dose and shielding calculations presented in Appendix A, it is envisioned that the excavator cabs will have to be equipped with extensive shielding 
(including leaded glass windshields and multiple layers of steel plate on the top, sides and bottom of the cab) and an air supply/air purification system. The study cost estimate includes provisions for optional elevated cabs, six inches of steel plate shielding on the roof, sides and floor of the cab, and specially fabricated six-inch thick leaded glass windshields. 
Figure 3.1. Excavator with Attachments

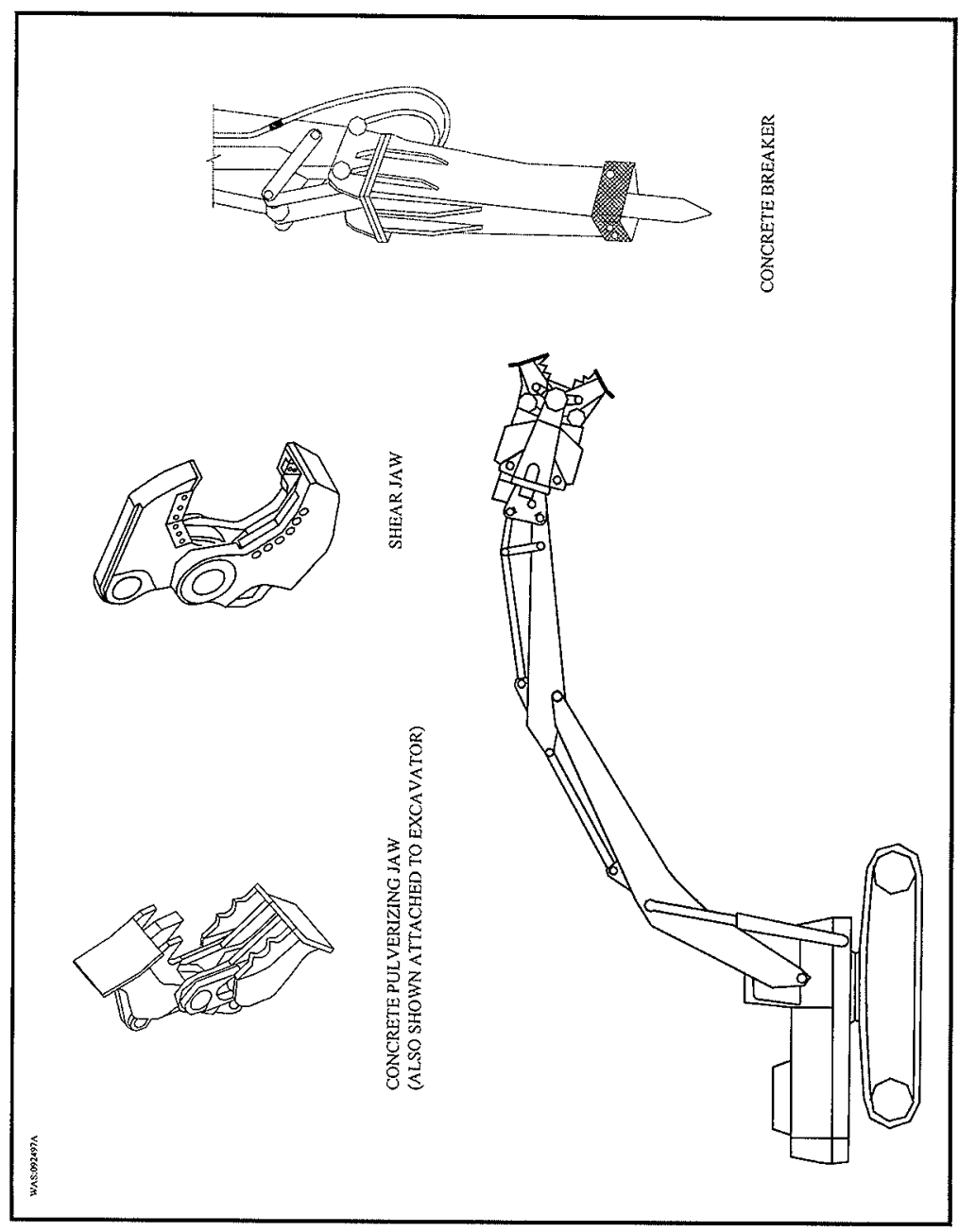


A front-end loader comparable to a Caterpillar 988 wheel loader will also be required for tank sidewall and base slab demolition. The cab of this unit would be modified to incorporate the same level of shielding as the excavator cabs. Four container-handling trucks will be used to move containers in and out of the excavation. To haul the heavy shielded containers that will be used to transport rubble from base slab demolition, the trucks will need to have four inches of steel shielding on the back of the cabs, and lesser thicknesses on the top and sides. Finally, a dozer comparable to a Caterpillar D10 is included in the estimate to address contingency situations where a piece of equipment is unable to exit the pit under its own power and must be dragged out.

\subsubsection{Related Decommissioning Experience}

Although decommissioning and closure of waste storage tanks is under active study at a number of DOE sites, actual removal of a full-size tank has not been undertaken at any site to date. A number of small research reactors and a few commercial reactors have undergone decommissioning, and these projects were reviewed to determine what demolition methods had been applied and the reported experiences with each.

One of the earliest of these projects was the Elk River Reactor (ERR) dismantling program (1971-1974) at Elk River, Minnesota. Several demolition methods were used. The eight-ft thick biological shield portion of the containment structure was demolished by controlled blasting. Blasting mats and continuous fog sprays of water were used to limit dust production. A wrecking ball was also used extensively, but only after all radiologically contaminated materials had been removed from the structure. Hydraulic pick breakers were used on an experimental basis at ERR, but productivity on thick reinforced concrete was considered unsatisfactory.

More powerful hydraulic breakers were used to dismantle the biological shield and other concrete portions of the R-1 research reactor in Stockholm, Sweden. One of the breaker units was mounted on a remote-controlled carrier.

Another such project was the decommissioning of the Sodium Reactor Experiment (SRE) in Chatsworth, California. This was a sodium-cooled, graphite-moderated research reactor. Decommissioning work was begun in 1968, and continued into the early 1980s. Unlike the Elk River program, the outer reactor building was not demolished at SRE. A plasma arc torch with remote controls was developed specifically to do the reactor core cutting work at SRE. A pick breaker was used successfully at SRE for light concrete demolition work.

The Shippingport reactor in western Pennsylvania was decommissioned beginning in the late $1980 \mathrm{~s}$. In that case, the entire pressure vessel and associated neutron shielding were removed as a single assembly. In the decommissioning plan for the Fort St. Vrain Nuclear Generating Station in Colorado, a variety of demolition strategies were proposed, including initial water flooding of the reactor vessel for shielding purposes; core drilling, diamond wire sawing and thermic lance cutting to remove the pressure vessel's top head concrete and liner elements, and a number of supplemental methods: plasma arch torch, portable band saws, hydraulic shears, and oxy-acetylene cutting for removal of segments of contaminated piping. 
Conclusions from the literature review were that:

- To date, no consistent methodology or strategy has evolved for demolition of heavily reinforced concrete structures where high radiation doses are involved.

- Potential technology transfer opportunities from the nuclear reactor decommissioning experience to tank removal appear to be limited.

Through separate sources, information was obtained regarding the recent demolition of a radiologically contaminated surplus building at the Mound Laboratory facility in Ohio. The task was accomplished by two hydraulic excavators with an assortment of specially designed hydraulic demolition implements mounted on the ends of the booms. These implements were easily able to pulverize concrete and shear through concrete reinforcement and structural steel supports. The implements include interchangeable pulverizers, shears, and hydraulic impact breakers. Based on this initial input, the technology was investigated in greater detail and ultimately was determined to be the most practical available approach for tank demolition.

\subsection{DESCRIPTION OF PROPOSED TANK REMOVAL CONCEPT}

The concepts and strategies that were developed in this engineering study for demolition of the four 241-AX tanks containing one percent residual waste inventories are discussed in this subsection. The discussion is organized and presented according to the major work elements involved and the sequence of activities.

\subsubsection{Tank Farm Enclosure and Support Facility}

3.3.1.1 Introduction. The site enclosure concept includes two connected structures. One will be a large enclosure structure that will span the entire length and width of the excavation. The other will house support facilities for the tank removal operation.

Confinement will be provided on a site-wide basis, by a single free-span structure. The enclosure will provide a large containment volume for controlling and filtering any particulate emissions generated by the tank removal operation so that contaminants are not dispersed into the outside environment. The support area includes a decontamination chamber for waste containers, which is similar to a car wash. The structure concept includes provisions for containing all contaminated water generated by the container decontamination process. The decontamination chamber will have provisions for remotely conveying containers through the decontamination process.

Site personnel and waste containers will enter and exit through air lock access points within the connected support facility structure. The support structure will also include a dressout area and separate radiation monitoring equipment for personnel and containers. The main structure includes a separate entry point for mobile equipment and an equipment decontamination area. 
3.3.1.2 Enclosure Description. The enclosure structure concept is an application of the STRARCH (STRessed ARCH) system, a technology developed several years ago in Australia. The STRARCH truss system combines three common design and construction principles: the arch, the truss, and pre-stressing cables. Application of this truss concept across the width dimension of the excavation will provide a single-span building with dimensions $500 \mathrm{ft}$ wide by $550 \mathrm{ft}$ long as depicted in Figures 3.2 and 3.3.

The STRARCH trusses will be supported on a concrete foundation consisting of individual spread footings connected by a continuous grade beam forming the perimeter of the building. This type of foundation provides solutions for two problems encountered with construction in tank farms facilities. The isolated spread footings will be large enough that pilings would not be required, thus avoiding potential intrusive interactions with adjacent tank farm facilities. The grade beam will also provide for attachment of an inner and outer building shell at grade to implement a double-confinement ventilation scheme within the enclosure.

Erection of the trusses on the foundation will be done as follows:

Each truss has a "fixed" end and a "sliding" end. Initially, the trussed frames are placed on temporary scaffolding in a horizontal plane near ground level. Next, the fixed end of each truss is pinned to the foundation. Purlins, interior and exterior siding, lighting, and fire protection components are installed with the trusses in this configuration. Pre-stressing cables are placed in the tubes forming the bottom chord of the trusses at this stage. After assembly, the pre-stressing cables are hydraulically tensioned to raise the structure to its final height, shape, and span. When the final configuration is achieved, the sliding end is secured to the foundation. 
Figure 3.2. Plan View of Enclosure

Structure over AX Tank Farm

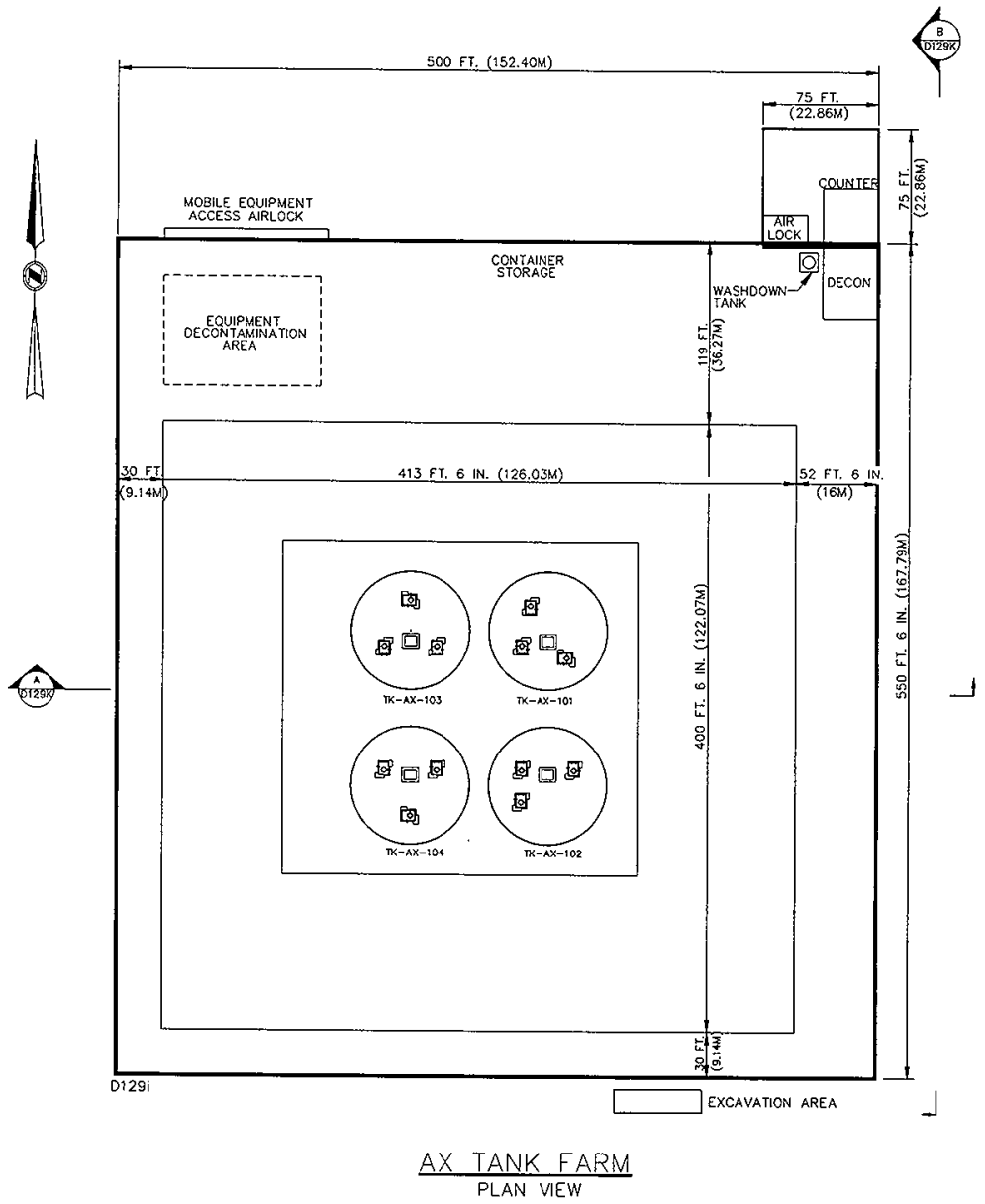


Figure 3.3 Section Views of

Tank Farm Enclosure Structure
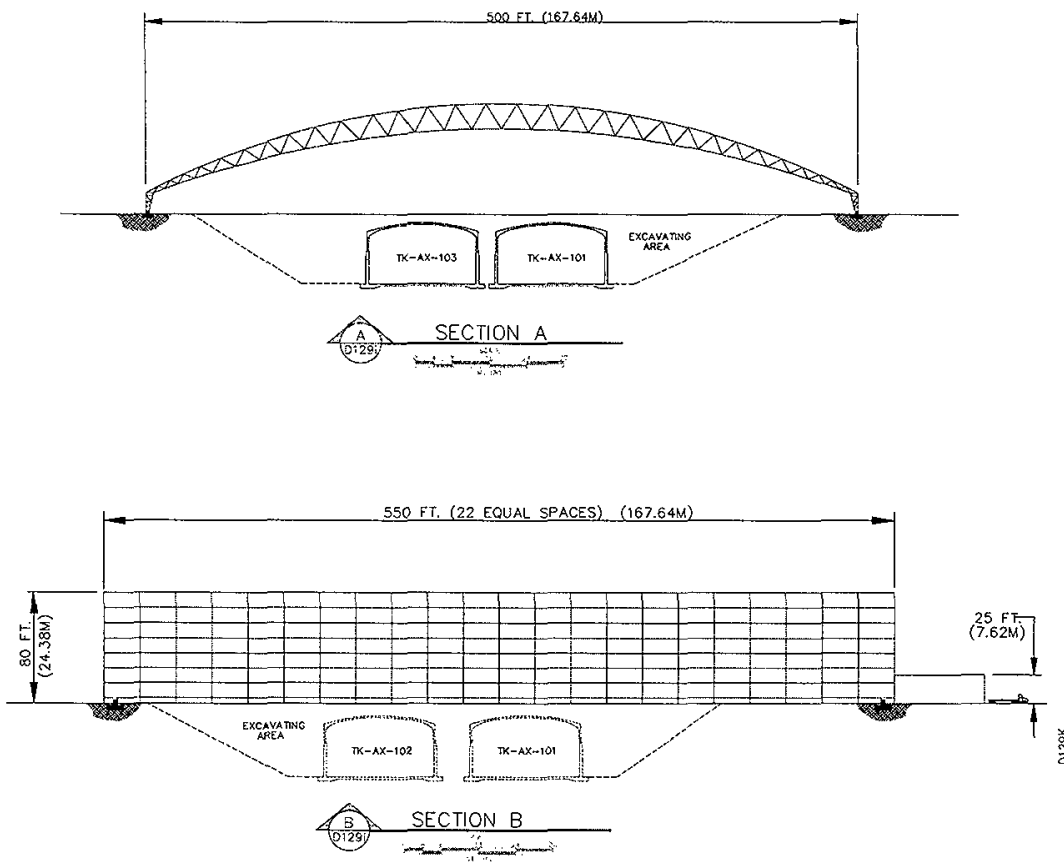
3.3.1.3 Support Facility. The support facility will be a prefabricated metal building $75 \mathrm{ft}$ wide by $75 \mathrm{ft}$ long with an eave height of approximately $20 \mathrm{ft}$. The foundation will be a six-inch slab on grade butted up to the perimeter foundation of the enclosure facility. Construction of the support facility will be by conventional methods.

3.3.1.4 Enclosure Ventilation. Two primary confinement zones will be provided. The open air volume inside the inner liner of the enclosure is designated as Zone 1 and will have the highest negative differential with respect to ambient pressure outside the enclosure. The annulus between the inner and outer liners of the enclosure is designated as Zone 2, which will be maintained at an intermediate negative pressure differential. Air will be supplied to Zone 1 along the east wall of the enclosure through stainless steel supply ducts provided with quick-closing isolation valves or shutters. No separate supply will be provided for Zone 2. Airflow into Zone 2 will be leakage through the inner shell of the building from Zone 1. Exhaust air will be removed from Zone 1 through four individual exhaust branches consisting of large stainless steel ducts suspended from the building trusses near the north west corner of each tank. The operator will be able to select individual exhaust branches depending on the progress of demolition work on individual tanks.

The exhaust from the two Zones will be treated by two separate groups of filtration units with two stages of HEPA filters equipped with individual isolation valves. The filter train for Zone 1 also will be provided with electrostatic precipitators to remove the majority of air-suspended dust. This feature will extend the service life of the HEPA filters. The support facility area will be maintained at a negative pressure between Zone 2 and the ambient and will be serviced by separate dedicated HVAC and exhaust filtration systems.

Principal features of the ventilation scheme are as follows:

- Zone 1 system: 112,500 SCFM supply and HEPA-filtered 122,500 SCFM exhaust.

- Zone 2 system: 7,000 SCFM HEPA filtered exhaust.

- Support facility HVAC system: supply unit capacity 4750 SCFM, 25 tons of refrigeration capacity, and $120 \mathrm{~kW}$ heating coil; exhaust unit capacity 5000 SCFM.

Although the enclosure structure will be a substantial structure in terms of its size, it is conceptualized as a temporary structure. The building ventilation concept conforms to the applicable requirements in DOE 6430.1A, with the following exceptions:

1. Section 1550-99.0.2 (Confinement Ventilation Systems):

a. The ventilation system is not designed to provide 100 percent standby capacity. The system is designed with approximately 30 percent spare capacity to facilitate filter changeouts. 
b. No diesel generators are provided for stand-by power.

2. Section 1550-1.5.3 (Personnel Ventilation Air Requirements):

Workers inside the enclosure will be required to use supplied personal breathing air except in designated support areas. The ventilation system would maintain $\mathrm{CO}_{2}$ and $\mathrm{CO}$ levels inside the enclosure within limits set by ASHRAE. However, the ventilation system may not conform to all requirements in ASHRAE 62-1989 with regard to dilution of vehicle exhaust emissions.

3.3.1.5 Lighting. Fixed lighting for operations will consist of low perimeter illumination and higher intensity illumination directly over the tanks. This concept is not intended to provide primary lighting for the tank removal operations, but rather supplemental lighting for any essential ancillary activities. All overhead lighting will be suspended from the arched trusses. The source of primary lighting for all tank operations will be by onboard lighting on support vehicles and operating equipment. To the extent that it is necessary and practical to do so, additional lighting could be provided by portable light plants.

3.3.1.6 Fire Protection. Fire protection for the interior of the enclosure will be suspended from the arched trusses. Zone 1 will be protected by dry foam and water spray systems. Water and foam delivery systems including reservoir, pumps, and piping will be sized for a four-hour fire. The support facility will be equipped with a conventional wet pipe system.

\subsubsection{Placement of Shielding Grout Inside Tanks}

The radiological source term in the four AX tanks (i.e., the one percent residual inventory) is large enough to require active management of worker exposures from the outset of tank removal. Dose assessments performed for this study (summarized in Appendix A) indicate that, during removal of cover soil over the domes, localized dose rates directly over the central portions of the domes of tanks AX-102, 103 and 104 would be in the range of 60 to $100 \mathrm{mrem} / \mathrm{hr}$ without supplemental shielding. At $60 \mathrm{mrem} / \mathrm{hr}$, a worker engaged in removing cover soil would accumulate his annual allowable dose $(1,500 \mathrm{mrem})$ in only 25 hours. Based on this assessment, it was concluded that some type of temporary shielding should be placed inside the tanks prior to initiating any actual decommissioning work on the tanks.

A safe, practical, and economical method of providing temporary shielding will be to pump some thickness of a cementitious mixture into the tanks to cover the source term, which is expected to be concentrated on the floor. A range of thicknesses of a hypothetical grout mix was evaluated for shielding effectiveness. It was shown that a one-foot thickness of a mix with a bulk density of about $140 \mathrm{lb} / \mathrm{ft}^{3}$ (a typical value for cementitious mixtures) would reduce worker dose rates by about two orders of magnitude.

A one-foot thickness of a highly flowable, self-leveling, low-strength grout will be pumped into the tanks. The selected formulation is Class A Controlled Density Fill (CDF), conforming to the material specification issued by the Washington Aggregates and Concrete Association (WACA 1997). Ingredients and proportions of Class A CDF are listed below. 


$\begin{array}{ll}\text { Ingredient } & \text { Quantity } / \mathrm{yd}^{3} \\ \text { Water } & 50 \mathrm{gal} \\ \text { Cement } & 30 \mathrm{lb} \\ \text { Fly Ash } & 200 \mathrm{lb} \\ \text { Dry Sand } & 3200 \mathrm{lb}\end{array}$

This is a low-strength ( $\left.<100 \mathrm{lb} / \mathrm{in}^{2}\right)$ grout with a bulk density of approximately $140 \mathrm{lb} / \mathrm{ft}^{3}$. The low compressive strength is desirable for ease of rubblization in conjunction with demolishing and removing tank base slab material.

Approximately $655 \mathrm{yd}^{3}$ of CDF will be dispatched from a local ready-mix company to cover the floor of the four tanks to a depth of one foot. Approximately 19 truck loads (at $9 \mathrm{yd}^{3} /$ truck) of grout will be pumped into each tank. Grout placement will take one eight-hour shift per tank. A local subcontractor would furnish a concrete pump truck with a 140 -ft boom and an operator. The remainder of the crew would consist of two Plant Forces health physics technicians to monitor zone entry/exit and ambient conditions within the tank farm, two laborers, and a flagger from Construction Forces who would assist the grout delivery and placement contractors (e.g., spotting the discharge end of the boom).

\subsubsection{Removal of Cover Soil}

For the purposes of this study, it is assumed that all riser penetrations (except one penetration per tank required for placement of shielding grout) will have been removed and all riser penetrations will have been plugged at the surface of the tank domes during remediation of ancillary facilities. With this assumption, no localized worker dose anomalies will be encountered at riser penetrations during the cover soil removal operation.

A second enabling assumption for this study is that all soil that must be removed to expose the four tanks will be presumed to be contaminated and will be moved to the Environmental Restoration Disposal Facility (ERDF) for disposal. By its nature, the excavation process will commingle soils that are contaminated to greater and lesser degrees, which would tend to thwart efforts to segregate nominally clean soil from contaminated soil. Efforts to segregate clean and contaminated would require extensive soil sampling and provisions for a large temporary holding area inside the enclosure structure for soil between sampling and analysis.

After placement of shielding grout inside the four AX tanks, dose calculations indicate that cover soil can be removed with conventional excavation equipment (i.e., the excavation equipment used to remove cover soil would not require any supplemental shielding). A shallow pit excavation will be developed in the process of exposing the four tank domes. After cover soil has been removed, the floor of the excavation will be approximately $12.5 \mathrm{ft}$ below grade, at the same level as the haunch of the tanks. A ramp (haul road) will be developed along the east side of the pit with entry from the north (see Figure 3.4). The ramp will be constructed with an eight-percent slope, which can be negotiated by all mobile equipment items involved in the operation. 
Excavation and transportation concepts were developed for this study conforming to the current ERDF operation. Contaminated soil will be moved from points of origin to ERDF in roll-on, roll-off (RO/RO) containers, which have a 20-ton capacity. The trucks used to transport RO/ROs are specially configured for handling (loading and unloading) containers of this type. Four container trucks will shuttle RO/ROs into and out of the excavation. These trucks will work exclusively inside the enclosure structure. These trucks are shown as capital in the cost estimate for the operation. Within the pit, RO/ROs will be loaded by a hydraulic excavator with a $3-\mathrm{yd}^{3}$ bucket. The total bank volume of soil to be removed is $20,500 \mathrm{yd}^{3}$ (or 27,675 $\mathrm{t}$ ), which equates to 1,384 container loads. Each container will undergo external decontamination and radiation survey as it is transferred from inside the enclosure structure to the outside. A separate fleet of container trucks will pick up RO/ROs outside the enclosure and haul them between AX Tank Farm and ERDF. These trucks and the containers are contractor furnished equipment. All contractor costs are included in the \$60/t ERDF disposal fee.

Cover soil removal will require a crew of eight (one excavator operator, one oiler, two health physics technicians, four teamsters) for six weeks. 
HNF-3378-Rev. 0

Figure 3.4. Pit Excavation After Cover Soil Removal

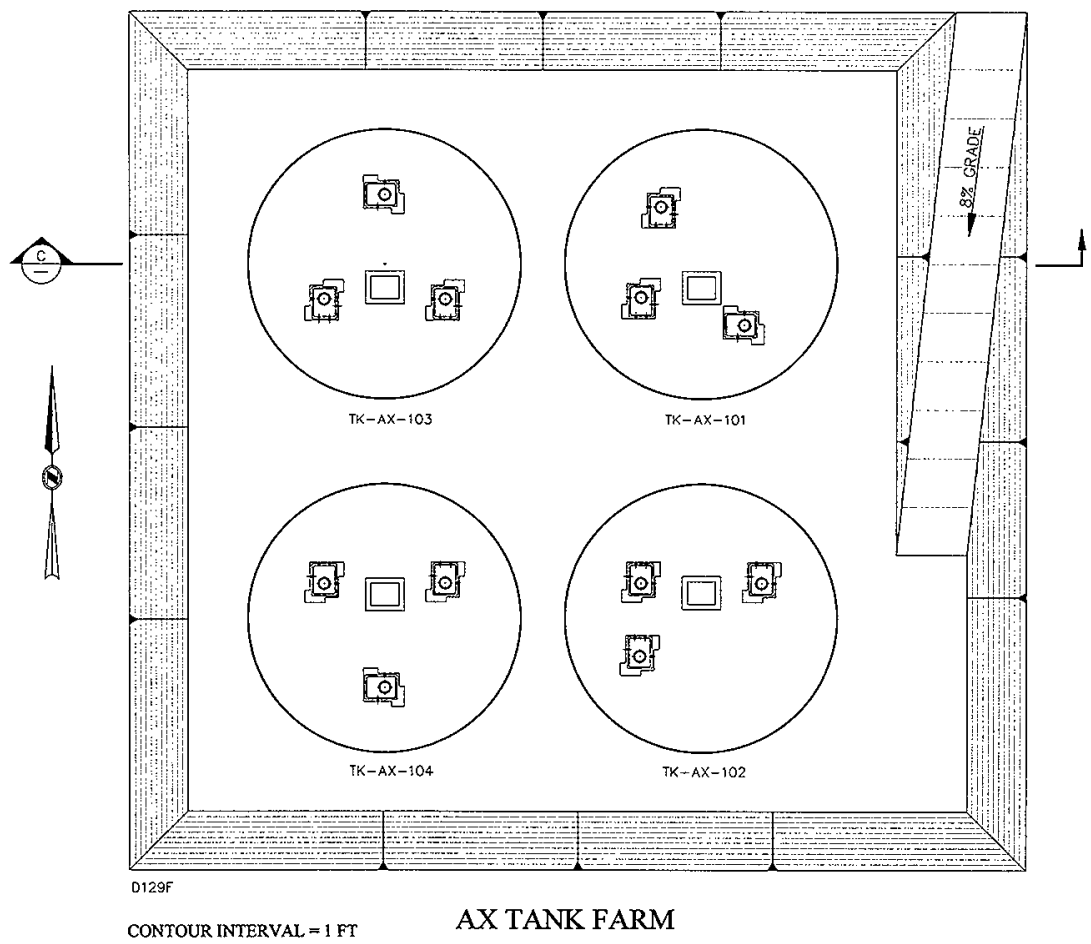




\subsubsection{Demolition/Removal of Tank Domes}

Using the selected demolition method (described in Section 3.2.3.3), tanks will be reduced to rubble beginning with the domes. Two hydraulic excavators equipped with specialized demolition implements will be used for concrete demolition work. The two excavators will work in tandem. Initially, a large hydraulic impact breaker will be mounted on one excavator. The second excavator will be equipped with a hydraulic shear jaw set capable of cutting completely through reinforced concrete panels up to 36 in thick. The initial effort will be to fracture a localized area in the central part of the dome with the impact breaker, severing imbedded rebar with the shear jaws as it becomes exposed. When a starter hole has been established, the impact breaker attachment will be exchanged for a concrete pulverizer jaw set. The pulverizer jaw crushes concrete into fine fragments that fall away from the reinforcing bar. The two excavators will work around the perimeter of each tank, with the lead unit pulverizing concrete around the edge of the hole and the second unit clipping off exposed rebar. In this manner, the starter hole will be expanded toward the haunch.

In the haunch area, tank domes are three to five $\mathrm{ft}$ thick and are very heavily reinforced. As the hole is enlarged toward the haunch, the pulverizer jaw set will become ineffective because the dome thickness approaches and then exceeds the jaw opening dimension. At this point in the operation, the pulverizer jaw set will be exchanged for the impact breaker. The breaker unit is capable of rubblizing as much as 45 to $65 \mathrm{yd}^{3}$ of reinforced concrete per day. The impact breaker and shear jaw attachments will be used for the remainder of the dome removal task. The excavators will work around the perimeter of each tank in sequence to rubblize the four domes.

As shown in Figures 3.4 and 3.6, the pit floor during dome removal is at the same elevation as the corner of the haunch (i.e., approximately $12.5 \mathrm{ft}$ below grade). Working from the peripheral area around the outside of the tanks, the excavators will have sufficient reach to completely rubblize the domes without having to move out onto the surface of the domes at any time.

Rubble from demolition of the dome and haunch will accumulate on the floor of each tank. Approximately $260 \mathrm{yd}^{3}$ of rubble will be created per tank from the dome removal operation. The rubble will form a second layer of temporary shielding material over the top of the CDF grout. The additional shielding value contributed by the rubble layer will have a significant impact on limiting worker doses during all subsequent tank removal activities.

Dome removal will be accomplished in 12 working days. The crew will consist of two excavator operators, two oilers (for scheduled maintenance), two health physics technicians, two laborers (who will assist with equipment decontamination when demolition implements have to be changed or unscheduled maintenance is necessary), and one millwright (who will be responsible for replacing wear parts and changing implements on the excavators).

\subsubsection{Lateral Soil Removal}

The extent of the excavation required to expose the sidewalls of the four AX tanks from the corner of the haunch down to the footings is shown in Figure 3.5 and 3.6. The sideslopes of the pit will be laid back at 1:1.5, which is the OSHA mandated limit for unsupported excavations in cohesionless soil. The access ramp (haul road) entering the pit from the northeast corner will be extended as the pit is deepened. The ramp will slope down at eight percent, which can be 
negotiated by all mobile equipment involved in the operation. At completion, the ramp will be approximately $650 \mathrm{ft}$ long, and will extend along the east and south sides of the pit, terminating on the west side. The final pit floor elevation will be approximately $52 \mathrm{ft}$ below grade.

As discussed in connection with removal of cover soil, the assumption has been made for this study that all soil that must be removed to expose the four tanks will be presumed to be contaminated and will be moved to ERDF for disposal in 20-ton capacity RO/RO containers. The total bank volume of lateral soil to be removed is $144,300 \mathrm{yd}^{3}$ (or 194,800 tons). At 20 tons per container, this amount of material equates to approximately 9,740 container loads. Four trucks will shuttle containers in and out of the pit, inside the AX tank farm enclosure. Containers will be loaded by one hydraulic excavator with a three-yard ${ }^{3}$ bucket. Approximately $44 \mathrm{RO} / \mathrm{RO}$ containers would be loaded and transported to ERDF per day. Although the equipment spread for tank removal includes two hydraulic excavators, rate-limiting factors for soil excavation are container size and movement. Using two excavators to load containers would not improve productivity. 
Figure 3.5. Pit Excavation After Lateral Soil Removal

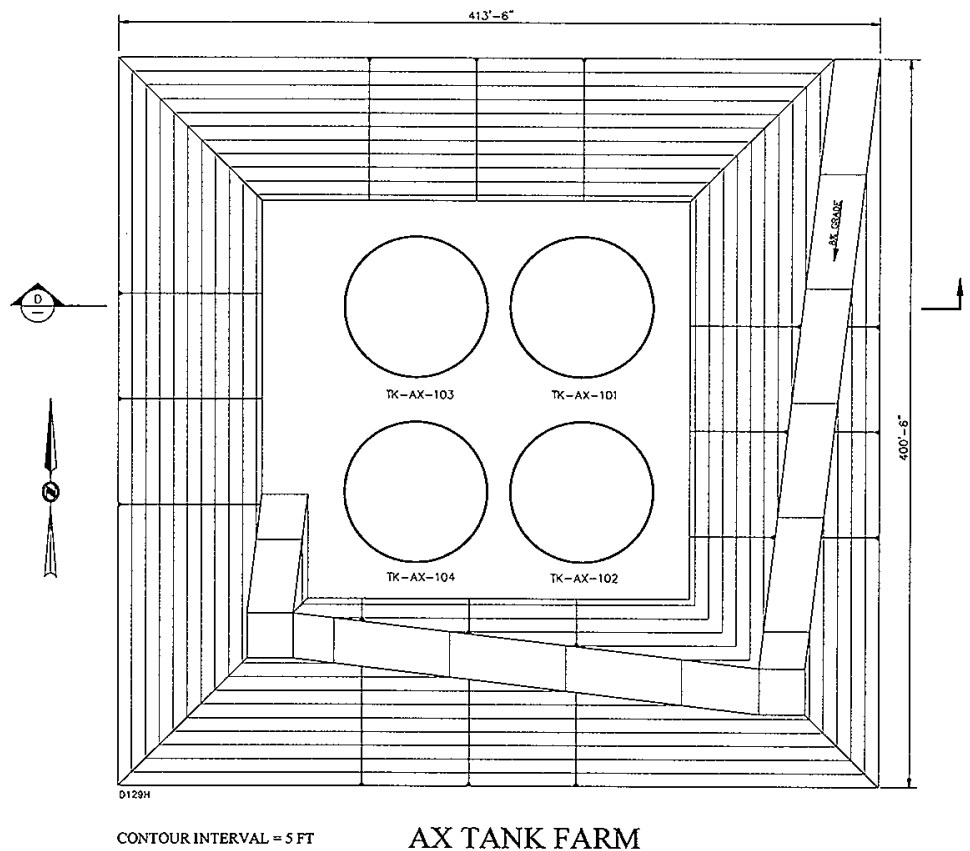


Figure 3.6. Pit Excavation Section Views
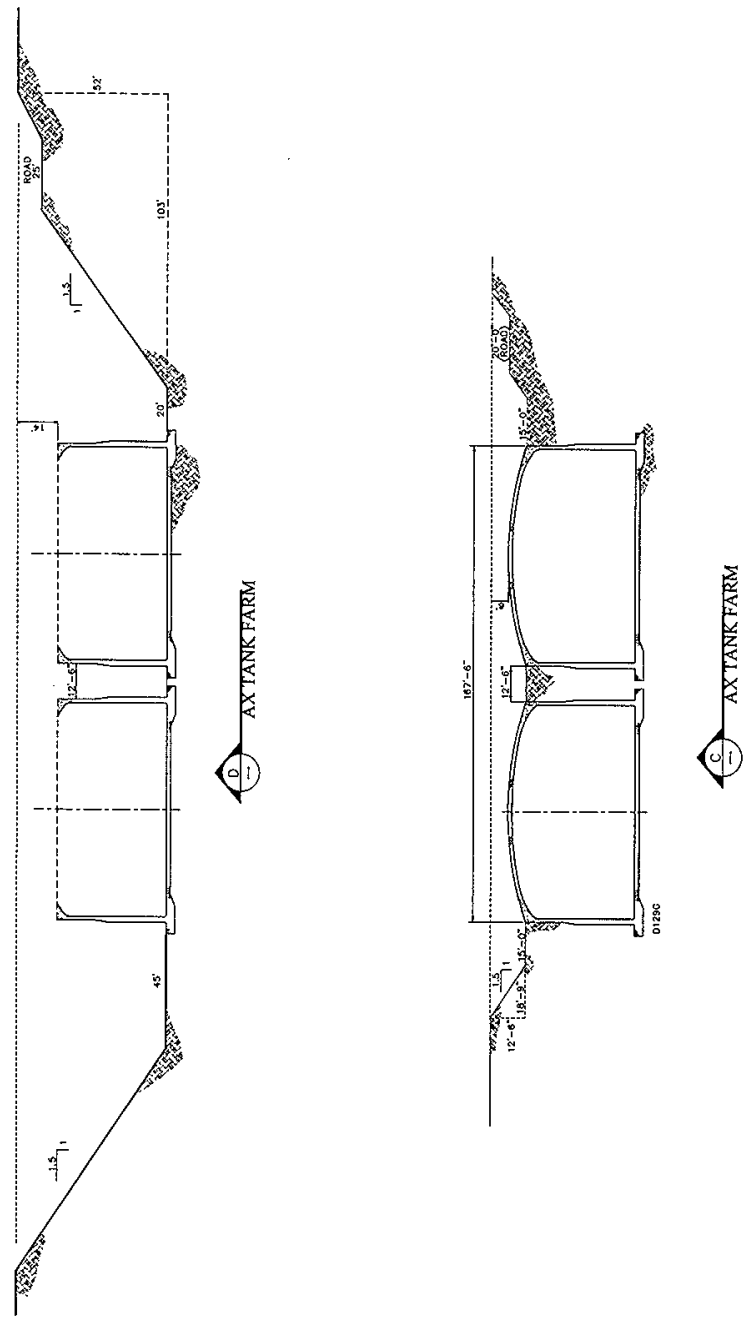
A separate fleet of container trucks will haul RO/ROs between AX tank farm and ERDF. These trucks and the containers are contractor furnished equipment. The \$60/t ERDF disposal fee includes contractor equipment costs. Lateral soil removal will require a crew of eight (one excavator operator, one oiler, four teamsters, and two health physics technicians) for 44 weeks.

\subsubsection{Demolition of Tank Sidewalls}

After removal of soil to expose the sidewalls of the four tanks, demolition work will resume with the sidewalls. For this activity, the two hydraulic excavators will be equipped with the pulverizer jaw and shear jaw implements. The two excavators will work together; the lead unit will pulverize concrete and the second unit will follow along behind and clip off rebar as it is exposed.

The outer sidewall height is approximately $38 \mathrm{ft}$ from the top of the footing ring to the corner of the haunch. The carbon steel liner covers the inside surface to a height of approximately $32.5 \mathrm{ft}$. Therefore, depending on the exact breakline left around the top of the sidewall when the tank domes are demolished, there will be approximately $5.5 \mathrm{ft}$ of exposed sidewall above the liner at the beginning of this task.

Approximately $61 \mathrm{yd}^{3}$ per tank of concrete rubble will be produced from demolition of the upper 5.5-ft sidewall interval. Portions of the rubble from this interval will fall to the inside and the outside of the tank. For estimating purposes, it is assumed that all $61 \mathrm{yd}^{3}$ would collect inside the tank and would be dispositioned (loaded out and hauled away) as part of the base slab rubble quantity.

When the sidewall has been demolished down to the top of the liner, the division of work between the two excavators will change somewhat. The excavator with the shear jaw implement will continue to trim exposed rebar as before. However, it will also be tasked with (1) pushing against the liner plate, forcing it away from the sidewall, so that the concrete edge remains accessible for the lead excavator (with the pulverizer jaw) to operate on, and (2) shear exposed portions of liner plate into 3 to $5-\mathrm{ft}^{2}$ segment. Liner plate segments will fall inward and accumulate on the floor of the tank. The liner plate pieces will be dispositioned with other base slab rubble.

It is assumed that all rubble concrete and rebar originating below the top of the liner will accumulate to the outside of the tank. Between the top of the liner and the top of footing ring, approximately $531 \mathrm{yd}^{3}$ of concrete rubble will be produced per tank. In the absence of any specific information regarding concrete contamination, it is assumed for purposes of this study that this rubble would not be heavily contaminated (i.e, would exhibit levels of contamination comparable to the surrounding soil) and could therefore be shipped to ERDF for disposal.

A front-end loader will work around the tanks behind the two excavators, loading concrete rubble into containers. The cab of the loader will be equipped with environmental isolation and shielding provisions comparable to the two excavators. It is estimated that demolition and removal of sidewall debris from the four $\mathrm{AX}$ tanks will require a crew of 15 for six weeks. The crew will consist of three operators, three oilers, two teamsters, four laborers, one millwright, and two health physics technicians. 


\subsubsection{Base Slab and Footing Ring Removal}

The final stage of tank demolition will involve the most adverse working and material handling conditions to be encountered at any time during the operation. In all of the activities performed up to this point, the soils and demolition debris that will have been removed from the site are expected to contain a small fraction of the overall radiological source term in the tank farm. The majority of the residual waste inventory is expected to be adhered to the liner plate over the floor area of the tank. It will be necessary for equipment operators to work in close proximity to the residual tank waste. Moreover, the cumulative effect of preceding activities (i.e, removal of surrounding soil and demolition of tank domes and sidewalls) will be to eliminate the beneficial effects of these materials as shielding.

The bottom surface area of each of the four AX tanks is approximately $4,420 \mathrm{ft}^{2}$. The bestestimate ${ }^{137} \mathrm{Cs}$ compositions in one-percent residual inventories for the four tanks are listed below, with corresponding concentrations over the bottom surface (assuming uniform distribution).

Tank

AX-101

$\mathrm{AX}-102$

$\mathrm{AX}-103 / 104$
${ }^{137} \mathrm{Cs}$ Inventory

(Ci)

5,160

7,170

10,900
${ }^{137} \mathrm{Cs}$ Concentration

$\left(\mathrm{Ci} / \mathrm{At}^{2}\right)$

1.17

1.62

2.47

These values were used to evaluate potential exposure consequences, shielding requirements for equipment operators, and packaging constraints for debris removal.

The initial aspect of base slab demolition will be to remove an eight-foot-wide strip of the liner around the perimeter of the tank that overlays the footing ring. The shear and pulverizer jaw implements will be used to accomplish this element of the work. To do so, the excavator with the pulverizer jaw will grab the exposed edge of the liner and lift it slightly, bending or curling it up so that pieces can be sheared off by the other unit. The front-end loader will work behind the two excavators loading rubble into shielded containers.

The next work element will be to rubblize the footing ring. The footing ring is $14 \mathrm{ft}$ wide and three $\mathrm{ft}$ thick. Because of the thickness of concrete involved, most of the demolition work on the footing ring will be done with the hydraulic impact breaker, supported by the shear jaw unit. This portion of the work will be similar to demolition of concrete in the haunch.

Base slab demolition can proceed to completion when the footing ring has been eliminated. The base slab thickness is $1.5 \mathrm{ft}$, which will enable the pulverizer jaw to be used for the remainder of the operation. As the liner edge is exposed, it will be curled up and sheared into manageably small (e.g., one $\mathrm{ft}$ by three $\mathrm{ft}$ ) pieces suitable to be loaded into shielded containers. Each time the liner edge is lifted and curled up, the temporary shielding materials (i.e., the CDF grout and concrete rubble from the dome and upper sidewall) will slough away, exposing a limited area of the liner surface with adhered tank waste. Because of the severe gamma radiation hazard posed by direct exposure of tank waste, continuous diligence will be required on the part of the excavator operators to do the work with the minimum essential amount of liner surface area 
exposed at any given time. Calculations to estimate shielding requirements for the various mobile equipment items (refer to Appendix A) assume that no more than $4 \mathrm{~m}^{2}$ of liner surface would be exposed at a time. Working behind the excavators, the front-end loader will transfer rubble into shielded containers. Significant improvements in worker exposure estimates can be achieved by loading out base slab debris quickly and efficiently.

Base slab rubble will consist of a mixture of liner scrap, shielding grout, concrete rubble, and some amount of soil from below the slab that will be picked up with the debris. For estimating purposes, the following itemization of debris was developed.

Concrete debris from dome and haunch $\left(319 \mathrm{yd}^{3} ; 20 \%\right.$ swell): $383 \mathrm{yd}^{3}$ Concrete debris from base slab and footing ring ( $458 \mathrm{yd}^{3} ; 20 \%$ swell): $550 \mathrm{yd}^{3}$ $\mathrm{CDF}$ grout rubble (164 yd $\mathrm{yd}^{3} ; 20 \%$ swell):

Tank Waste $\left(360 \mathrm{ft}^{3}\right)$ : Liner plate scrap (assuming 500\% swell): $197 \mathrm{yd}^{3}$ Soil (uniform 3-in. lift under slab; $20 \%$ swell):

Based on these values, base slab rubble is expected to exhibit specific activity levels of ${ }^{137} \mathrm{Cs}$ in the range of 0.2 to $0.5 \mathrm{Ci} / \mathrm{ft}^{3}$. As solid waste, the rubble would be categorized as remote-handle TRU. No existing waste package design is suitable for transporting material with ${ }^{137} \mathrm{Cs}$ activity levels in this range (WHC 1995). A completely new container would have to be developed for on-site transportation of base slab debris.

For this study, it was assumed that the same fleet of container-handling trucks used to transport $\mathrm{RO} / \mathrm{RO}$ containers would be used for hauling packaged base slab debris. These trucks have a $38,000-1 b$ payload limit. Shielding calculations indicate that a package with a given aspect ratio of 1:1.2:4 would require four inches of steel on the top and sides to limit doses to $10 \mathrm{mrem} / \mathrm{hr}$ at $1 \mathrm{~m}$. Such a container would have a payload volume of about $117 \mathrm{ft}^{3}$. Assuming a unit weight of rubble of $102 \mathrm{lb} / \mathrm{ft}^{3}$ and complete filling, the package would weigh about $26,000 \mathrm{lb}$ and could hold about $12,000 \mathrm{lb}$ of base slab rubble. For estimating purposes, the assumption was made that only about $3.5 \mathrm{yd}^{3}$ of debris (corresponding to a fill factor of 80 percent) would actually be loaded into any given container. This would likely be done in practice as a way to avoid overfilling a container (making it difficult to close and secure it for shipping) and/or inadvertently loading too much ${ }^{137} \mathrm{Cs}$ activity into any one package. Based on this information, approximately 365 packaged loads of base slab debris will be produced per tank.

The packaged debris would be hauled approximately one mile to a waste processing facility, which is assumed to be colocated with the TWRS waste vitrification facilities. Costs developed for loadout and removal of base slab debris include transportation costs but exclude any costs for design, safety analysis, fabrication, or procurement of the transport packages. It is assumed that the packages would be "owned" by the waste processing facility (i.e., package costs would be included with capital costs for the facility) and that they would be designed to be reusable.

Base slab demolition will be performed by a crew of 20 , consisting of three equipment operators, three oilers, four teamsters, two health physics technicians, six laborers, and two millwrights. 
The laborers would support equipment decontamination and movement of containers through the airlocks into and out of the enclosure. The millwrights would support maintenance and repair of demolition equipment. Base slab demolition will take approximately 32 days to complete.

\subsubsection{Backfilling the Excavation After Tank Removal}

Costs are included in the Tank Removal Estimate for backfilling the excavation after all tank removal and soil remediation activities have been completed. For estimating purposes, direction was provided to assume that Pit 30 would be the source for the fill. A total of $164,800 \mathrm{yd}^{3}$ of soil will be excavated from the site during the tank removal operation. An additional volume of $27,700 \mathrm{yd}^{3}$ will be required to replace the volumes of the four AX tanks. Another 19,900 $\mathrm{yd}^{3}$ of material will be required to replace soil excavated for deep soil remediation (COGEMA Engineering $1997^{b}$ ). The combined (bank) volume is $212,400 \mathrm{yd}^{3}$. This total was increased by 10 percent. Any excess material would be placed as a uniform surcharge over the site. The total volume of material to be hauled and placed is $234,000 \mathrm{yd}^{3}$. No compaction effort will be applied to the fill other than the wheel loads of placement equipment. A unit weight of $120 \mathrm{lb} / \mathrm{ft}^{3}$ was assumed.

Four truck tractors with $20-\mathrm{yd}^{3}$ dump trailers will be used to haul and place material. The four trailers will be loaded at Pit 30 by a front-end loader with a 5-yd $\mathrm{y}^{3}$ bucket. The one-way haul is approximately five miles. Material will be spread and graded by a dozer working inside the tank farm excavation. The work will take approximately 49 weeks to complete. As directed, no other site restoration costs were developed.

\subsection{IMPLEMENTABILITY ISSUES}

\subsubsection{Scaleup of Enclosure Structure Concept}

The enclosure structure proposed in this study to provide containment for the tank removal operation is a free-span structure that will cover an area $500 \mathrm{ft}$ wide by $550 \mathrm{ft}$ long. The structure concept is based on the application of STRARCH trusses with a 500-ft span. Similar enclosure designs have been proposed in other TWRS engineering studies (e.g., McConville 1995). Based on the available information, the 500-ft STRARCH truss span would involve a modest scale-up from existing applications, and therefore appears to be a practical design solution for the enclosure over the 241-AX Tank Farm. Most other SST farms include three or four rows of tanks. The STRARCH concept may not be adaptable for constructing much larger free-span structures over other tank farms. To that extent, the concepts developed in this study for removing AX farm tanks may not be transferable directly to other farms.

\subsubsection{Worker Dose and Shielding Estimates}

Scoping estimates of worker dose and shielding requirements have been made as part of this study. Preliminary best-basis inventory estimates for the one percent residual inventories in tanks were used in the scoping calculations. The estimates indicate that tank removal would be feasible for the given inventory estimates, based on the proposed shielding strategies and the projected efficiencies for accomplishing the work with the equipment spread identified for the concept operation. 
An essential element of the tank removal strategy is to provide heavy shielding for cabs of all mobile equipment pieces working in the pit excavation. The hydraulic excavators and the frontend loader would have six inches of steel plate on exterior surfaces of the cabs and six-inch windshields of high-density leaded glass. These modifications would increase the weights of these items by about $50,000 \mathrm{lb}$ each. Modifications of equipment items to carry the extra weight are regarded to be feasible, although it is conceded that significant equipment redesign would likely be required.

A modest increase in the ${ }^{137} \mathrm{Cs}$ quantities in the best-basis inventories have the effect of increasing shielding requirements (and weight) for all mobile equipment items involved. There is some limit to the workability of this strategy, and the current concept may already be approaching that limit. There is some risk that the concept may cease to be practical if ${ }^{1{ }^{17} \mathrm{Cs}}$ inventories exceed the current estimates or worker productivities are significantly below expectations.

\subsubsection{Radionuclides in Air-Suspended Particulates}

Estimates of air-suspended particulates are provided in the data tables in Section 3.5. The method that was used to estimate radionuclides in particulates is described in the notes that accompany the tables. No standard method or experienced-based precedent is known for preparing estimates of this kind. Based on the assumptions applied, these estimates are believed to be highly conservative. However, the estimates are speculative, and supporting evidence is unavailable to substantiate the computational method or the results.

The intentional conservatism in radionuclide emissions estimates could have unintended consequences. The estimates could become the basis for the erroneous argument that tank removal cannot be done because public health and safety risks would be unacceptable (e.g., because of actinides in emissions). The recommendation would be that this aspect of the tank removal study results should be examined in greater detail as a separate activity.

\subsubsection{Worker Health and Safety Considerations}

It is envisioned that personnel working inside the pit excavation would be limited to teamsters and equipment operators in shielded cabs with on-board supplied air (i.e., all in-pit work would be "mask work"). The building ventilation system is designed to sweep air towards the pit, be collected in overhead ducts, and be then filtered and exhausted. This arrangement implies that support work in other areas of the building may not need to be done "on mask." However, for estimating purposes it was assumed that all remediation work would be mask work.

Worker dose estimates for construction of the enclosure structure indicate that cumulative doses could be significant during that portion of the operation. However, the dose rate for that activity is the assumed local background, $50 \mathrm{microrem} / \mathrm{hr}$, which is less than detectable with personal dosimeters. The cumulative doses are more reflective of the long duration of construction rather than the presence of a dangerous radiological source while construction is being done.

Due to the essential conceptual nature of this study, the opportunity to address contingencies relating to radiological safety and develop specific strategies for worker protection during offnormal events is limited. For these reasons, worker health and safety provisions may be overestimated or underestimated. 


\subsubsection{Packaging and Disposition of Base Slab Rubble}

Based on a limited evaluation of the issue made during the tank removal study, it is understood that average ${ }^{137} \mathrm{Cs}$ concentrations in base slab debris would be so high that a new, heavily shielded container would have to be designed to enable the debris to be loaded out and removed from the pit excavation. Base slab debris probably would be designated as remote-handled TRU. The weight of an adequately shielded container would severely limit cargo capacity. At the present time, there is no on-site facility that is equipped to receive, store, or handle remotehandled TRU waste in significant quantities. Nor is there a plan to make such a facility available in the foreseeable future.

Consequently, packaging and disposition of base siab rubble is an open interface issue. Costs were included in the estimate for this study for transportation of base slab debris in small-volume shielded containers to a nearby point. No costs are included for procurement of the specialized transport packages that would be required or for any form of waste treatment. These issues will be addressed in a future engineering study.

\subsubsection{Environmental Restoration Disposal Facility Interface}

It has been assumed for this study that all soil excavated to expose the four AX tanks down to the footing ring level would be assumed to be contaminated and would be transported to ERDF for disposal. At the present time, ERDF is chartered to accept only waste from CERCLA remedial action sites at Hanford. Additionally, ERDF will only take waste with acceptable constituents in concentrations that do not exceed facility-specific waste acceptance criteria. It is currently unclear how these constraints would be resolved. Tank farms are not classified as CERCLA remedial action sites. Contaminated soil from tank farms may contain constituents, including land-banned constituents, which ERDF would be unable, under State of Washington regulations, to accept. ERDF waste acceptance criteria may have to be broadened to accommodate material originating in tank farms or a separate-but-equivalent disposal facility for tank farms waste may have to be constructed.

\subsection{ENGINEERING DATA TABLES}

Data tables (3.2 through 3.5.2) have been assembled to summarize the labor, equipment, and resources that would be committed to expose and demolish the four tanks in the 241-AX tank farm as per the concepts proposed and described above in this section. The tables also provide summary estimates of waste types and forms, emissions, and worker exposures that would be produced as consequences of prosecuting the work. This section includes as well information on project cost and schedule as well (Table 3.6 and Figure 3.7). Additional detail on project costs is presented in Appendix B. The estimate methodology is explained in Tables B-3 through B-6.

These tables do not include any quantities pertaining to the two leakage cases (i.e., hypothetical 8,000 -gal and 40,000-gal leakage events during tank waste retrieval). Impacts on tank removal in response to leakage during waste retrieval are addressed separately in Section 4.0 of this report. 
Table 3.2. Waste Form and Volume Projections

\begin{tabular}{||l|l||}
\hline \multicolumn{1}{|c|}{ Waste Form } & \multicolumn{1}{|c|}{ Characteristic } \\
\hline \hline Cover Soil & \\
Waste volume (in place) & $20,500 \mathrm{yd}^{3}$ \\
Number of containers & 1,384 container loads \\
Container size & $20^{\prime} \mathrm{L} \times 7.5^{\prime} \mathrm{W} \times 5.5^{\prime} \mathrm{H}$ \\
Radionuclide Inventory & $($ Note 1$)$ \\
Disposal location & Environmental Restoration Disposal Facility \\
\hline Lateral Soil & \\
Waste volume (in place) & $144,300 \mathrm{yd}^{3}$ \\
Number of containers & 9,740 container loads \\
Container size & $20^{\prime} \mathrm{L} \times 7.5^{\prime} \mathrm{W} \times 5.5^{\prime} \mathrm{H}$ \\
Radionuclide Inventory & $($ Note 1$)$ \\
Disposal location & Environmental Restoration Disposal Facility \\
\hline Concrete Rubble from Tank Sidewalls & \\
Waste volume (in place) & $2,124 \mathrm{yd}^{3}$ \\
Number of containers & 213 container loads \\
Container size & $20^{\prime} \mathrm{L} \times 7.5^{\prime} \mathrm{W} \times 5.5^{\prime} \mathrm{H}$ \\
Radionuclide Inventory & $($ Note 1$)$ \\
Disposal location & Environmental Restoration Disposal Facility \\
\hline Rubble from Domes and Base Slabs & \\
Waste volume (loose) & $5,100 \mathrm{yd}^{3}$ \\
Number of containers & 1,460 container loads \\
Container size & $12.1^{\prime} \mathrm{L} \times 4.2^{\prime} \mathrm{W} \times 3.3^{\prime} \mathrm{H}$ \\
Radionuclide Inventory & $($ Note 2$)$ \\
Disposal location & TWRS Vitrification Facility \\
\hline \hline
\end{tabular}

Note 1: For this study, soil excavated to expose tanks and concrete debris from demolition of the tank sidewalls were assumed to exhibit sufficiently low levels of radiological and nonradiological contamination to conform to ERDF waste acceptance criteria, (i.e., that these materials would be acceptable for disposal at ERDF). Concurrently, it was assumed that a negligible portion of the one percent residual waste inventory in the four AX tanks would be present in these materials.

Note 2: It was assumed for this study that virtually all of the one percent residual waste inventory in the four AX tanks would be adhering to the liner plate, principally on the floor of tanks. Consequently, the assumed radionuclide inventory in rubble from demolition of the tank domes, liner plate and base slabs is the estimated one percent residual inventory for the four tanks. 
Table 3.3. Construction Resource Requirements

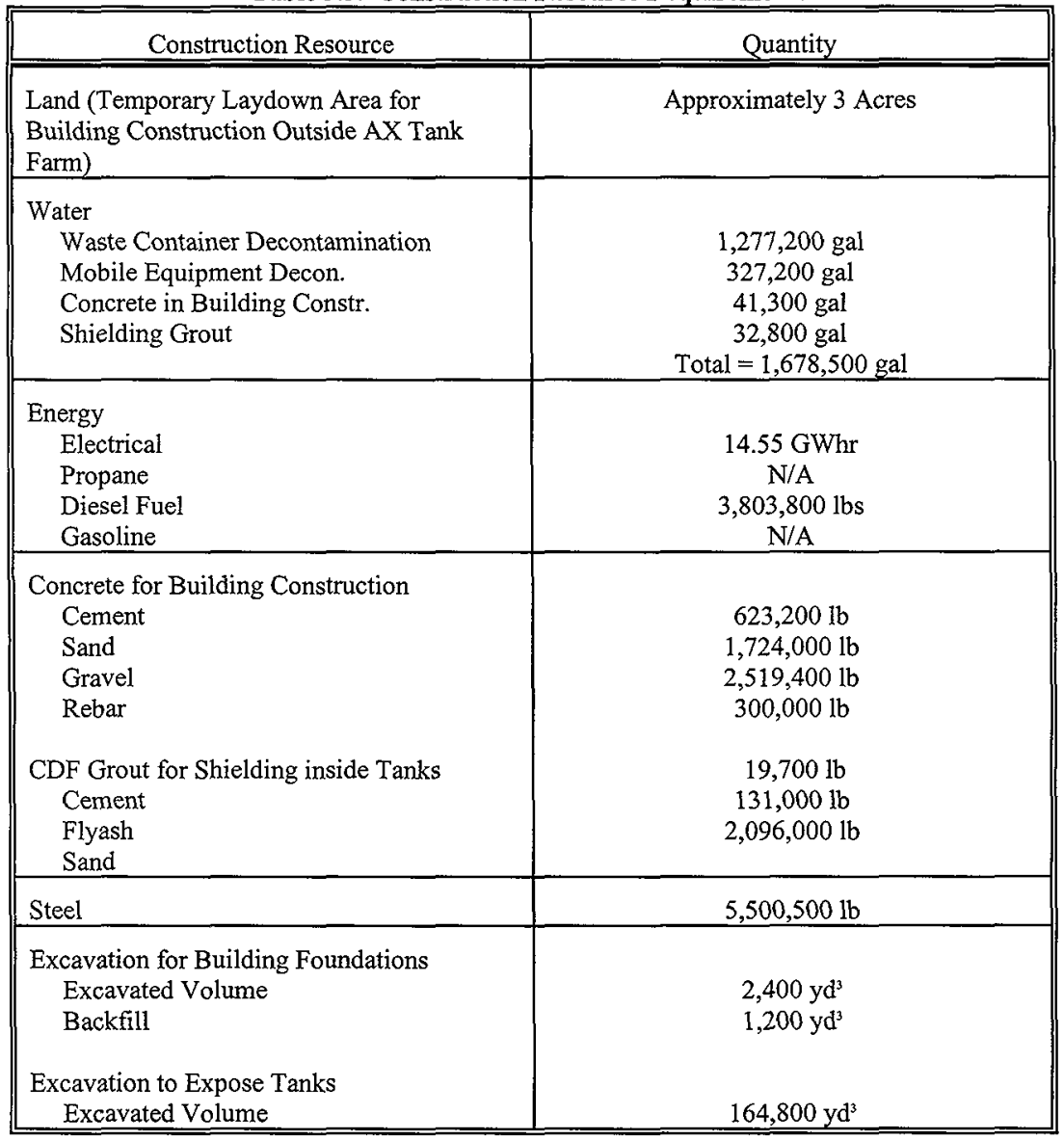

Notes regarding water consumption:

Waste container decontamination: 100 gal/container

Mobile equipment decontamination: $200 \mathrm{gal} /$ day per item

Notes regarding electrical energy consumption: Refer to Figure 3.7 for construction schedule information. 
Power use estimate:

Use rate during building construction:

All sources: $(2 \mathrm{kw})(8 \mathrm{hrs} /$ day $)(350$ days $)=5,600 \mathrm{kWhr}$

Power use estimate (continued):

Use Rate During Tank Removal:

Ventilation: $=(1,400 \mathrm{HP})(0.746 \mathrm{kw} / \mathrm{HP})(24 \mathrm{hrs} /$ day $)(7 / 5)(328$ days $)$

Lighting: $=(275 \mathrm{kw})(24 \mathrm{hrs} /$ day $)(7 / 5)(328$ days $)$

All Other: $=(1.5 \mathrm{kw})(8 \mathrm{hrs} / \mathrm{day})(328$ days $)$

$=11,510,123 \mathrm{kWhr}$

$=3,030,720 \mathrm{kWhr}$

$=3,936 \mathrm{kWhr}$

Total electrical consumption

Notes regarding fuel consumption calculations: Fuel consumption was calculated based on engine specific fuel consumption data provided by Caterpillar Inc. and the equipment spread, duty cycle, and engine model data listed below. Rated fuel consumption for CAT $3406 \mathrm{CATAAC}$ engine is $149.24 \mathrm{lb} / \mathrm{hr}$; for CAT $3408 \mathrm{TA}$ engine is $167.44 \mathrm{lb} / \mathrm{hr}$.

Enclosure Construction:

$\begin{array}{llccc} & \text { Schedule } & \text { Util__Rate } & \text { Opr. Hours } & \text { Engine } \\ \text { (2) 200-T Crane } & 42 \mathrm{Wks} & 70 \% & 2,352 & \text { CAT 3406CATAAC } \\ \text { (2) 40-T Crane } & 70 \mathrm{Wks} & 70 \% & 3,920 & \text { CAT 3408TA } \\ \text { (2) Svc. Trucks } & 70 \mathrm{Wks} & 20 \% & 1,120 & \text { CAT 3408TA }\end{array}$

Tank Demolition/Removal:

(2) Excavators

Schedule Util.Rate

Opr. Hours

Engine

(1) Wheel Loader

(Varies)

$70 \%$

1,811

282

CAT 3406CATAAC

(4) Haul Trucks

(Varies)

$70 \%$

5,405

CAT 3408TA

(Varies)

$70 \%$

CAT 3408TA

Container-Handling Trucks (Assuming $25 \mathrm{mph}$ average speed; CAT 3408TA engines):

Hauling to ERDF (9 mi haul)

Hauling to Vit Plant (1 mi haul)

$\begin{array}{rrr}\text { Trips } & \text { Mileage } & \text { Hours } \\ 11,337 & 204,066 & 8,163 \\ 1,460 & 2,920 & 117\end{array}$


Operating Hours and Fuel Consumption:

CAT 3406CATAAC: $2,352+1,811=4,163 \mathrm{hrs}$

Fuel Consumption $=(4,163 \mathrm{hrs})(149.24 \mathrm{lb} / \mathrm{hr})$ $=621,300 \mathrm{lbs}$

CAT 3408TA: $3,920+1,120+282+5,405+8,163+117=19,007 \mathrm{hrs}$

Fuel Consumption $=(19,007 \mathrm{hrs})(167.44 \mathrm{lb} / \mathrm{hr})$ $=3,182,500 \mathrm{lbs}$

Total Fuel Consumption $=621,300 \mathrm{lbs}+3,182,500 \mathrm{lbs}$ $=3,803,800 \mathrm{lbs}$ 
Table 3.3.1. Particulate Emissions Originating Outside of AX Tank Farm from Activities Associated with Tank Removal

\begin{tabular}{||c|c|}
\hline Activity & $\begin{array}{c}\text { Particulate Emissions } \\
\text { (tonne) }\end{array}$ \\
\hline \hline $\begin{array}{c}\text { Clearing and Grubbing of } \\
\text { Laydown Area for } \\
\text { Building Constr. Materials }\end{array}$ & 0.18 \\
\hline $\begin{array}{c}\text { Paved Road Transportation } \\
\text { of Waste Containers }\end{array}$ & 12.5 \\
\hline
\end{tabular}

Notes regarding emissions calculations:

Dozer Grading - Laydown Area:

Area $=3$ Acres

Duration $=21$ Days

Particulate Emissions $=0.18$ tonne

(Basis: Clearing and grubbing emissions estimates, Kline et al (1995) Table A-10, p. A-36). Silt content $6 \%$; soil moisture content 3 percent.

Paved Road Transportation Particulate Emissions:

Emissions Factor: $\mathrm{EF}=220\{\text { (silt load) } / 12\}^{0.3}$

silt load $=\%$ silt $=5 \%$

$\mathrm{EF}=220\{5 / 12\}^{0.3}=169.2 \mathrm{~g} / \mathrm{km}$

Cover Soil:

Lateral Soil:

Sidewall Concrete:

Dome/Base Slab Rubble:
Trips

1,384

9,740

213

1,460
Haul Dist.

$6.4 \mathrm{~km}$

$6.4 \mathrm{~km}$

$6.4 \mathrm{~km}$

$1.3 \mathrm{~km}$
Emissions

1.5 tonne

10.5

0.2

0.3

12.5 tonne

The emission factor is the amount of PM 10 particles in grams/vehicle kilometer traveled. (Basis: Estimation procedure provided in EPA 451/R-93-004, "Estimation of Air Impacts from Area Sources of Particulate Matter Emissions at Superfund Sites," Report ASF-32.) 
Table 3.3.2. Construction Vehicle Emissions ${ }^{(1)}$

\begin{tabular}{||c|c|c|c||}
\hline $\begin{array}{c}\text { Emissions } \\
\text { Category }\end{array}$ & $\begin{array}{c}\text { Building Constr. } \\
\text { Quantity (lb) }\end{array}$ & $\begin{array}{c}\text { Tank Removal } \\
\text { Quantity (lb) }\end{array}$ & $\begin{array}{c}\text { Waste Transport } \\
\text { Quantity (lb) }\end{array}$ \\
\hline \hline Particulates & 272 & 282 & 331 \\
\hline $\mathrm{SO}_{x}$ & 4,779 & 4,889 & 5,544 \\
\hline $\mathrm{CO}$ & 6,104 & 6,435 & 7,952 \\
\hline Hydrocarbons & 258 & 246 & 219 \\
\hline $\mathrm{NO}_{x}$ & 42,656 & 43,257 & 47,729 \\
\hline Aldehydes & N/A & N/A & N/A \\
\hline $\begin{array}{c}\text { Organic Acids } \\
\text { Thermal Releases } \\
\text { Btu }\end{array}$ & N/A & N/A & N/A \\
\hline $\mathrm{NH}_{3}$ & $2.197 \mathrm{E} 10$ & $2.248 \mathrm{E} 10$ & $2.550 \mathrm{E} 10$ \\
\hline \hline
\end{tabular}

Note 1: Quantities were calculated based on engine exhaust chemistry data provided by Caterpillar Inc. and the equipment spread, duty cycle, and engine model data listed in notes following Table 3.2.

Note 2: Thermal Releases: Thermal releases were calculated assuming that diesel engines lose 75 percent of the energy content of fuel consumed (18,390 Btu/lb; $1055.1 \mathrm{~J} / \mathrm{Btu}$ ) as heat (source: Kline et al 1995, Table A-10, Note 5).

Fuel Quantities:

CAT 3406CATAAC: CAT 3408TA:

Bldg. Constr. Tank Removal Haul to ERDF

$351,000 \quad 270,300 \quad$ (none)

$843,900 \quad 952,200 \quad 1,386,400$ 
Table 3.3.3. Estimates of Particulate Emissions from Confinement Structure over AX Tank Farm During Tank Removal

\begin{tabular}{||l|c|c||}
\hline \multicolumn{1}{|c|}{ Source } & $\begin{array}{c}\text { Estimated } \\
\text { Dust Production }\end{array}$ & $\begin{array}{c}\text { Estimate of Emissions } \\
\text { from Enclosure }\end{array}$ \\
\hline \hline $\begin{array}{l}\text { Dust production from } \\
\text { loading of soil into } \\
\text { containers }\end{array}$ & $230 \mathrm{~kg}$ & $11.5 \mathrm{~g}$ \\
\hline $\begin{array}{l}\text { Concrete dust from } \\
\text { pulverizing tank domes, } \\
\text { sidewalls, and base slabs }\end{array}$ & $187 \mathrm{~kg}$ & $9.4 \mathrm{~g}$ \\
\hline $\begin{array}{l}\text { Pulverized tank waste } \\
\text { produced by cutting liner } \\
\text { apart }\end{array}$ & $197 \mathrm{~kg}$ & $9.8 \mathrm{~g}^{(2)}$ \\
\hline
\end{tabular}

Note 1: The air filtration system will consist of electrostatic precipitators ahead of HEPA filters. The combined decontamination factor for the two filtration elements is estimated to be about 20,000. HEPA filter elements alone are about 99.97 percent efficient (corresponding to a DF of 3,333 ), so the combined DF is expected to be conservative. In general, all particles that pass through HEPA filters are in the minus 0.3 micron size fraction.

Note 2: An estimate of the radiological inventory contained in the $9.9 \mathrm{~g}$ of emissions originating from tank waste is tabulated separately (refer to Table 3.3.4).

Additional Notes re. Calculations of Fugitive Dust Generated During Demolition and Loadout of Soil and Debris:

A. Dust Generated During Loading of Soil into Containers:

$\operatorname{Mass}(M)=(1,384+9,740$ containers $)(20 \mathrm{t} /$ container $)(2,000 \mathrm{lb} / \mathrm{t})(\mathrm{kg} / 2.2 \mathrm{lb})$

$$
=2.022 \times 10^{\circ} \mathrm{kg}
$$

Particle size multiplier $(\mathrm{K})=0.35$

Mean air velocity $(\mathrm{U})=1 \mathrm{~m} / \mathrm{sec}$ (assumed)

Moisture content $\left(\mathrm{xH}_{2} \mathrm{O}\right)=3$ percent (assumed)

$$
\begin{aligned}
\mathrm{E} & =(\mathrm{K})(0.0016)(\mathrm{M})(\mathrm{U} / 2.2)^{1.3} /(\mathrm{xH} 2 \mathrm{O} / 2)^{1.4} \\
& =(0.35)(0.0016)\left(2.022 \times 10^{\circ} \mathrm{kg}\right)\left[(\mathrm{U} / 2.2)^{1.3}\right] /(3 / 2)^{1.4}
\end{aligned}
$$




$$
=230 \mathrm{~kg}
$$

(Basis: Estimation procedure provided in EPA 451/R-93-004, "Estimation of Air Impacts from Area Sources of Particulate Matter Emissions at Superfund Sites," Report ASF-32.)

B. Concrete Dust Generated by Pulverizing Tank Domes, Sidewalls, and Base Slabs:

Pulverization of reinforced concrete produces a significant amount of airsuspended particulates. Case-history-based data on particulate emissions is unavailable from vendor sources. It is understood from discussions with equipment vendors that dust generation from such activities varies considerably with the age and composition of the concrete undergoing size reduction, increasing the difficulty in predicting emissions for any given situation. For the tank removal application, the following hypothetical estimate has been developed:

In-place volume of concrete to be pulverized:

$319 \mathrm{yd}^{3} / \operatorname{tank}$ in dome and haunch

$458 \mathrm{yd}^{3} / \operatorname{tank}$ in base slab and footing ring

Total Volume $=777 \mathrm{yd}^{3} / \operatorname{tank} \mathrm{x} 4$ tanks $=3,108 \mathrm{yd}^{3}$

Assume 50 percent of total volume is demolished with pulverizer jaw and 50 percent is demolished with impact breaker, and pulverizer jaw produces five times as much dust as impact breaker.

$$
\text { Effective Pulverized Volume }=0.5(3,108)+0.5(3,108 / 5)=1,865 \mathrm{yd}^{3}
$$

Based on visual assessments of dust production in vendor videos, it is estimated that perhaps as much as 100 grams of air-suspended dust would be produced per cubic yard of concrete pulverized.

$$
\begin{aligned}
\text { Dust Production } & =\left(100 \mathrm{~g} / \mathrm{yd}^{3}\right)\left(1,865 \mathrm{yd}^{3}\right) \\
& =186,500 \mathrm{~g}=186.5 \mathrm{~kg}
\end{aligned}
$$

C. Radiological Emissions in Air-Suspended Solids:

As indicated in Section 3.3.7, liner plate will be sheared into manageably small (nominally one $\mathrm{ft}$ by three $\mathrm{ft}$ ) pieces to be loaded into shielded transport packages. Insofar as the tank demolition method proposed in this study has never been attempted in a radiological environment, there is no experience basis for evaluating how much of the residual waste inventory adhering to the inside of the tank liner might be pulverized as the liner plate is sheared into pieces. Because dust-size particles of tank waste could conceivably become suspended in air during loadout of base slab debris, an estimate of the potential dust production 
from this source is of considerable interest. A hypothetical estimate is provided below. However, it should be emphasized that this is a speculative exercise, lacking any basis in experience.

Assume all contamination is adhered to the floor of the tanks. The bottom surface area of the tanks is approximately $4,420 \mathrm{ft}^{2}$. Assume that the liner plate covering the floor is sheared into rectangular pieces, each measuring one $\mathrm{ft}$ by three $\mathrm{ft}$. The total sheared length to produce such pieces is approximately:

$$
\begin{aligned}
4,420 \mathrm{ft}^{2} / 3 \mathrm{ft}^{2} \text { per piece } & =1,473 \text { pieces per tank } \\
& \text { or } 5,892 \text { pieces total }
\end{aligned}
$$

$$
\begin{aligned}
\text { Sidelength/tank } & =[(8 \mathrm{ft} / \text { piece }) /(2 \text { sides })](1,473 \text { pieces } / \text { tank }) \\
& =5,892 \text { lineal } \mathrm{ft} \text { per tank }
\end{aligned}
$$

Each tank is assumed to contain $360 \mathrm{ft}^{3}$ of residual waste, which corresponds to a thickness of one in of waste uniformly distributed over the floor of the tank. Assume that a 1/4-in-wide zone of this one-in waste layer is pulverized as the liner plate is sheared.

Pulverized volume/tank $=\left[(0.25 \mathrm{in}).(1 \mathrm{in}.) / 144 \mathrm{in}^{2} / \mathrm{ft}^{2}\right](5,892 \mathrm{ft})$

$$
=10.23 \mathrm{ft}^{3} \text { per tank }
$$

Additionally, assume that 10 percent of the pulverized waste volume becomes suspended in air during loadout of debris.

$$
\begin{aligned}
\text { Air-suspended tank waste dust } & =(0.10)\left(10.23 \mathrm{ft}^{3}\right) \\
& =1.02 \mathrm{ft}^{3} \text { per tank }
\end{aligned}
$$

Corresponding masses of tank waste vary from tank to tank according to the waste specific gravity reported for each tank.

$\begin{array}{clll}\text { Tank } & \text { Sp.Gr. } & \text { Volume to Mass } & \text { Mass/DF } \\ \text { AX-101 } & 1.573 & 1.02 \mathrm{ft}^{3}=45.4 \mathrm{~kg} & 2.27 \mathrm{~g} \\ \text { AX-102 } & 1.57 & 1.02 \mathrm{ft}^{3}=45.4 \mathrm{~kg} & 2.27 \mathrm{~g} \\ \text { AX-103 } & 1.80 & 1.02 \mathrm{ft}^{3}=52.1 \mathrm{~kg} & 2.61 \mathrm{~g} \\ \text { AX-104 } & 1.80 & 1.02 \mathrm{ft}^{3}=52.1 \mathrm{~kg} & 2.61 \mathrm{~g}\end{array}$


Table 3.3.4. Radiological Inventory in Particulate Emissions (Curies) ${ }^{1}$

\begin{tabular}{||l|l|l|l|l||}
\hline Radionuclide & \multicolumn{1}{|c|}{ AX-101 } & \multicolumn{1}{|c|}{ AX-102 } & \multicolumn{1}{c|}{ AX-103 } & \multicolumn{1}{|c||}{ AX-104 } \\
\hline \hline${ }^{14} \mathrm{C}$ & $1.8 \mathrm{E}-8$ & $1.4 \mathrm{E}-8$ & 0 & $3.5 \mathrm{E}-8$ \\
\hline${ }^{60} \mathrm{Co}$ & $2.9 \mathrm{E}-7$ & $3.5 \mathrm{E}-8$ & $8.6 \mathrm{E}-6$ & $9.4 \mathrm{E}-6$ \\
\hline${ }^{90} \mathrm{Sr}$ & $1.6 \mathrm{E}-2$ & $7.4 \mathrm{E}-3$ & $7.5 \mathrm{E}-2$ & $7.5 \mathrm{E}-2$ \\
\hline${ }^{99} \mathrm{Tc}$ & $4.6 \mathrm{E}-7$ & $5.4 \mathrm{E}-7$ & 0 & $2.5 \mathrm{E}-7$ \\
\hline${ }^{129} \mathrm{I}$ & $2.3 \mathrm{E}-10$ & $9.5 \mathrm{E}-8$ & 0 & $4.7 \mathrm{E}-10$ \\
\hline${ }^{137} \mathrm{Cs}$ & $7.3 \mathrm{E}-4$ & $1.0 \mathrm{E}-3$ & $1.5 \mathrm{E}-3$ & $1.5 \mathrm{E}-3$ \\
\hline${ }^{239 / 20} \mathrm{Pu}$ & $7.9 \mathrm{E}-5$ & $3.0 \mathrm{E}-5$ & $1.9 \mathrm{E}-5$ & $1.9 \mathrm{E}-5$ \\
\hline${ }^{241} \mathrm{Am}$ & $2.5 \mathrm{E}-5$ & $2.3 \mathrm{E}-4$ & 0 & $5.6 \mathrm{E}-6$ \\
\hline
\end{tabular}

Note 1: Radionuclide concentrations in emissions are assumed to be the same as the best-estimates of concentrations in residual tank waste reported by COGEMA Engineering (1997a). 
Table 3.4. Personnel Requirements

\begin{tabular}{||c|c|c||}
\hline \multirow{2}{*}{ Category } & \multicolumn{2}{|c|}{ Construction (FTEs) } \\
\cline { 2 - 3 } & Rad Workers & Non-Rad Workers \\
\hline \hline Building Constr. & & \\
Supervisory & 0 & 15 \\
Direct Labor & 0 & 58 \\
\hline Tank Removal & & \\
Supervisory & 8 & 1 \\
Direct & 20 & 0 \\
\hline
\end{tabular}

FTE: full-time equivalent 
Table 3.5.1. Worker Exposure Estimates

\begin{tabular}{|c|c|c|}
\hline Unit Process/Crew & $\begin{array}{c}\text { Avg. Exposure Rate } \\
(\mathrm{mrem} / \mathrm{hr})\end{array}$ & $\begin{array}{c}\text { Individual } \\
\text { Dose(mrem/indiv.) } \\
\end{array}$ \\
\hline $\begin{array}{l}\text { Construct Enclosure ( } 350 \text { Days) } \\
4 \text { Carpenters } \\
6 \text { Laborers } \\
4 \text { Operators } \\
2 \text { Oilers } \\
10 \text { Ironworkers } \\
10 \text { Sheetmetal workers } \\
12 \text { Sprinkler fitters } \\
10 \text { Electricians } \\
\end{array}$ & $\begin{array}{l}0.05 \\
0.05 \\
0.05 \\
0.05 \\
0.05 \\
0.05 \\
0.05 \\
0.05 \\
\end{array}$ & $\begin{array}{r}16 \\
78 \\
84 \\
78 \\
26 \\
130 \\
54 \\
50\end{array}$ \\
\hline $\begin{array}{l}\text { Place CDF Grout (4 Days) } \\
1 \text { Pump Truck Operator } \\
2 \text { HPTs } \\
2 \text { Laborers } \\
\text { 1 Flagger } \\
\end{array}$ & $\begin{array}{c}0.05 \\
5.0 \\
5.77 \\
0.05 \\
\end{array}$ & $\begin{array}{l}1.3 \\
130 \\
150 \\
1.3 \\
\end{array}$ \\
\hline $\begin{array}{c}\text { Remove Cover Soil (30 Days) } \\
1 \text { Excavator Operator } \\
1 \text { Oiler } \\
2 \text { HPTs } \\
4 \text { Teamsters } \\
\end{array}$ & $\begin{array}{c}0.058 \\
0.05 \\
0.05 \\
0.055 \\
\end{array}$ & $\begin{array}{c}11.3 \\
9.8 \\
9.8 \\
10.7 \\
\end{array}$ \\
\hline $\begin{array}{l}\text { Remove Tank Domes (12 Days) } \\
2 \text { Excavator Operators } \\
2 \text { Oilers } \\
2 \text { HPTs } \\
2 \text { Laborers } \\
1 \text { Millwright } \\
\end{array}$ & $\begin{array}{l}0.06 \\
0.16 \\
0.16 \\
0.16 \\
0.16 \\
\end{array}$ & $\begin{array}{c}4.7 \\
12.5 \\
12.5 \\
12.5 \\
12.5 \\
\end{array}$ \\
\hline $\begin{array}{l}\text { Remove Lateral Soil (220 Days) } \\
1 \text { Excavator Operator } \\
1 \text { Oiler } \\
2 \text { HPTs } \\
4 \text { Teamsters } \\
\end{array}$ & $\begin{array}{l}0.07 \\
0.13 \\
0.13 \\
0.17 \\
\end{array}$ & $\begin{array}{l}100 \\
186 \\
186 \\
243 \\
\end{array}$ \\
\hline $\begin{array}{l}\text { Remove Tank Sidewalls ( } 30 \text { Days) } \\
2 \text { Excavator Operators } \\
1 \text { Front-End Loader Opr. } \\
3 \text { Oilers } \\
2 \text { HPTs } \\
2 \text { Teamsters } \\
4 \text { Laborers } \\
1 \text { Millwright } \\
\end{array}$ & $\begin{array}{l}0.35 \\
0.35 \\
0.25 \\
0.25 \\
0.41 \\
0.25 \\
0.25 \\
\end{array}$ & $\begin{array}{l}69 \\
69 \\
50 \\
50 \\
79 \\
50 \\
50 \\
\end{array}$ \\
\hline
\end{tabular}


HNF-3378-Rev. 0

\begin{tabular}{||c|c|c|}
\hline Unit Process/Crew & $\begin{array}{c}\text { Avg. Exposure Rate } \\
\text { (mrem/hr) }\end{array}$ & $\begin{array}{c}\text { Individual } \\
\text { Dose(mrem/indiv.) }\end{array}$ \\
\hline \hline Remove Base Slabs (32 Days) & & \\
2 Excavator Operators & 1.80 & 375 \\
1 Front-End Loader Opr. & 1.80 & 375 \\
3 Oilers & 0.25 & 52 \\
2 HPTs & 0.25 & 52 \\
4 Teamsters & 1.58 & 329 \\
6 Laborers & 0.25 & 52 \\
2 Millwrights & 0.25 & 52 \\
\hline
\end{tabular}

Table 3.5.2. Cumulative Exposure Estimates by Unit Process

\begin{tabular}{||l|c||}
\hline \multicolumn{1}{||}{ Unit Process } & $\begin{array}{c}\text { Cumulative Doses } \\
\text { (mrem) }\end{array}$ \\
\hline \hline Construct Enclosure & 3,732 \\
\hline Place CDF Grout & 563 \\
\hline Remove Cover Soil & 84 \\
\hline Remove Tank Domes & 97 \\
\hline Remove Lateral Soil & 1,630 \\
\hline Remove Tank Sidewalls & 865 \\
\hline Remove Base Slabs & 3,117 \\
\hline \hline
\end{tabular}


Table 3.6. Cost Breakdown

\begin{tabular}{|c|c|}
\hline Cost Component & $\operatorname{Cos} t^{(1)}$ \\
\hline Post-Retrieval Monitoring and Maintenance & N/A \\
\hline $\begin{array}{l}\text { Capital } \\
\text { Building Construction } \\
\text { Soil Removal and Tank Demolition } \\
\text { Disposal of Soil and Debris } \\
\text { Site Remediation - Backfilling }\end{array}$ & $\begin{array}{r}21,150,000 \\
40,000,000 \\
18,370,000 \\
1,810,000 \\
\\
\text { Total }=81,330,000 \\
\end{array}$ \\
\hline Research and Development & $\mathrm{N} / \mathrm{A}$ \\
\hline Operating & N/A \\
\hline Decontamination and Decommissioning & N/A (Note 1) \\
\hline
\end{tabular}

Note 1: Costs are rounded to the nearest $\$ 10,000$. Costs include contingencies averaging 22 percent (itemized in Appendix B). Costs do not include escalation (all costs are in \$1998).

Note 2: Scope of work for this study does not include disposition of enclosure structure. Regrading (backfilling) costs applicable to the earthwork in this study are identified above as capital costs. 
AX-Tank Farm Tank Removal Schedule (in Manths)

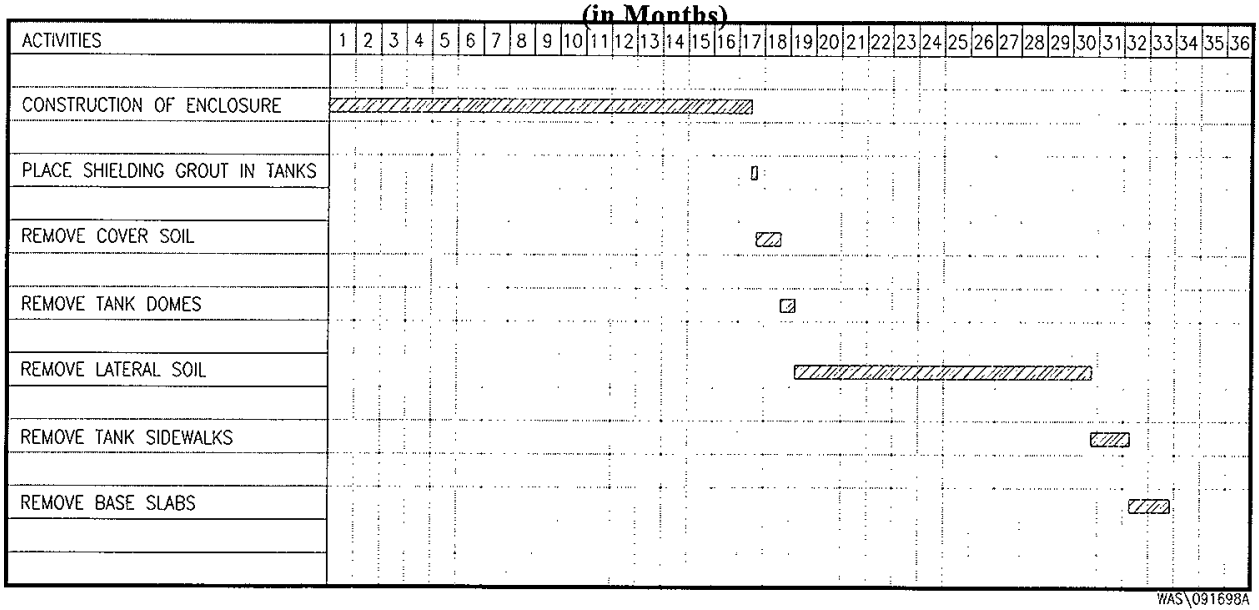




\subsection{LEAKAGE ASSESSMENTS}

\subsection{INTRODUCTION}

The SOW for this study directs COGEMA Engineering to evaluate the impacts of two hypothetical leakage cases on tank removal. The two scenarios address the anticipated range of potential losses of sluicing liquids into the soil column during retrieval of tank waste. Sluicing is the current baseline technology for retrieval. The volume for the minimum leakage case is 8,000 gal. This value is traceable to the minimum detection level associated with the current leak detection method, which is mass balance (Hertzel 1997). The volume for the maximum leakage case, 40,000 gal, corresponds to the maximum plausible leak during retrieval from Tank C-106 as determined by Lowe (1993).

There are several important distinctions between the remediation "base case" summarized in Section 3.0 and the leakage scenarios that will be considered here. The extent of vadose zone contamination in the base case is modeled after the inferred actual condition. As summarized in Section 2.0, locations and ${ }^{137} \mathrm{Cs}$ concentrations of existing vadose zone plumes have been defined, and reasonable assessments have been made regarding their vertical and lateral extent and physical interactions. The highest measured ${ }^{137} \mathrm{Cs}$ concentration value in the vadose zone at $\mathrm{AX}$ tank farm is about $4 \mathrm{nCi} / \mathrm{g}$. Existing plumes are artifacts of leaks and spills that occurred $20-30$ years ago; it is unlikely that significant spreading (plume growth) is still taking place.

The leakage scenarios are hypothetical. Given information for the scenarios is limited to liquid volumes and chemical inventories. The leak location, the volume and geometry of contaminated soil, maximum contaminant concentrations, and the variation of contaminants (particularly ${ }^{137} \mathrm{Cs}$ ) in the soil away from the entry point are undefined. For the purpose of exploring these scenarios, inference and assumptions must be applied to fill gaps in problem definition. Based on the large quantities of ${ }^{137} \mathrm{Cs}$ and ${ }^{90} \mathrm{Sr}$ in the best-basis leakage inventory data, it can be expected that peak concentrations in soil from a sluicing leak would be several orders of magnitude higher than the highest measured values from existing contamination. Consideration must also be given to the potential for an extended period of time to pass between the leakage event and remediation. Extensive spreading of the initial plume volume could be expected to occur as a consequence.

\subsection{ESTIMATION OF CONTAMINATED SOIL VOLUMES}

To develop an estimate of the volumes of soil that would be impacted by releases of 8,000 gal or 40,000 gal, assumptions must be made concerning moisture retention properties of the soil. Soils in the textural classes that include "cobbly sand," "sand," "fine sand," and "loamy sand" exhibit field capacity values ranging from 4.5 to 10.5 percent and wilting point values from about 2.0 to 4.5 percent. Residual (ambient) moisture content in the middle levels of the vadose zone is variable, but through most of the year, it is likely to be in the range of 3.5 percent to 4.5 percent (i.e., in the upper part of the wilting point range). Based on these presumptive material properties, it can be inferred that the excess moisture-holding capacity for the soils in question would be limited to about six volume percent. With these assumptions, the calculated extent of 
an 8,000 -gal leak would be $17,825 \mathrm{ft}^{3}$ of soil and the extent of a 40,000 -gal leak would be 89,127 $\mathrm{ft}^{3}$ of soil.

A number of hypothetical leakage scenarios for the 241-AX tank farm were investigated by numerical modeling methods by Piepho et al. (1996). Leakage volumes ranging from 4,000 gal to 160,000 gal were considered. The predicted plumes all tended to have geometries that could be idealized as half-ellipsoids with variable aspect ratios, depending on the size of the leak and the time elapsed between leakage and remediation. The model results also indicated that, over periods of tens of years, leakage plumes could undergo significant (i.e., $2 \mathrm{X}$ to $3 \mathrm{X}$ ) vertical spreading as a conseqence of deep infiltration of meteoric water (i.e., rainfall, snowmelt). In recognition of these results, supplemental guidance was issued to the study team as follows:

- Assume an aspect ratio of $1.5: 1(\mathrm{~V}: \mathrm{H})$ for the 8,000-gal plume.

- Assume an aspect ratio of 2:1 (V:H) for the 40,000-gal plume.

- Double the plume dimensions in $X, Y$, and $Z$ to account for the effects of spreading and delayed response.

With the original volume estimates described above and the supplemental assumptions, the following descriptions were developed for the two leakage plumes:

- The 8,000-gal leakage case: Half ellipsoid with (equal) minor axes of $35.7 \mathrm{ft}$ (in the horizontal plane) and major axis of $53.6 \mathrm{ft}$ (vertical); plume volume is $5,300 \mathrm{yd}^{3}$.

- The 40,000-gal leakage case: Half ellipsoid with (equal) minor axes of $55.4 \mathrm{ft}$ (in the horizontal plane) and major axis of $110.8 \mathrm{ft}$ (vertical); plume volume is $26,400 \mathrm{yd}^{3}$.

\subsection{CONTAMINANT INVENTORY AND ${ }^{137}$ CESIUM AND ${ }^{90}$ STRONTIUM DISTRIBUTIONS IN LEAKAGE PLUMES}

Inventory projections for individual tank waste constituents in leakage volumes were developed by COGEMA $\left(1997^{2}\right)$. The leakage inventories for ${ }^{80} \mathrm{Sr}$ and ${ }^{137} \mathrm{Cs}$ are reproduced in Table 4.1. 
Table 4.1. Total Activities from Various Leakage Volumes and Sources (in Curies)

\begin{tabular}{|c|c|c|c|c|}
\hline \multirow{2}{*}{$\mathrm{A}_{\text {total }}$} & \multicolumn{2}{|c|}{8,000 -Gallon Leak } & \multicolumn{2}{c|}{40,000 -Gallon Leak } \\
\cline { 2 - 5 } & $\mathrm{Sr}-90$ & $\mathrm{Cs}-137$ & Sr-90 & Cs-137 \\
\hline \hline $\mathrm{AX}-101$ & 4,473 & 2,364 & 22,363 & 11,820 \\
\hline $\mathrm{AX}-102$ & 11,133 & 4,731 & 55,667 & 23,654 \\
\hline $\mathrm{AX}-103$ & 95,354 & 4,161 & 476,772 & 20,805 \\
\hline $\mathrm{AX}-104$ & 130,938 & 2,716 & 654,692 & 13,581 \\
\hline \hline
\end{tabular}

Normally, in soil contaminated with mixed fission products, ${ }^{137} \mathrm{Cs}$ is the principal contributor to direct exposure dose. In this case, ${ }^{90} \mathrm{Sr}$ may also be a signficant dose contributor considering the extremely large inventory values involved. Radiation from ${ }^{50} \mathrm{Sr}$ decay has a very short penetration range in soil. Decay of ${ }^{137} \mathrm{Cs}$ produces a strong gamma product that can penetrate two to three $\mathrm{ft}$ of soil, depending on the soil density.

Cesium and strontium concentrations in the leakage plumes will be nonuniform. Both constituents sorb onto the soil column. The highest concentrations of sorbed contaminants in soil should occur at the point of entry of liquid into the soil. Concentrations should decrease away from the entry point in all directions where transport (i.e., moisture movement) takes place. For the two leakage cases, it is assumed that the point of entry would occur at the footing level (i.e., at the floor elevation of the pit excavation) on the perimeter of one of the four tanks.

The SOW requests an assessment of worker radiological exposure consequences for the two leakage scenarios. Due to the self-shielding property of soil and the sorption and retention of disproportionate amounts of ${ }^{137} \mathrm{Cs}$ and ${ }^{90} \mathrm{Sr}$ at or near the pit floor level, a method is required for making a reliable estimate of the fraction of the inventories for these constituents that would be retained at depths less than the self-shielding limits. A reliable estimation method is not presently available.

Mathematical models of ${ }^{137} \mathrm{Cs}$ and ${ }^{90} \mathrm{Sr}$ distributions in soil were devised for the purpose of examining potential worker exposure consequences. The models are integral equations in which ${ }^{137} \mathrm{Cs}$ and ${ }^{90} \mathrm{Sr}$ concentrations vary vertically but are invariant in the horizontal plane. The gradient expression was based on the observed variation of ${ }^{137} \mathrm{Cs}$ with depth in Drywell 11-03-02 as reported in DOE/GJO (1997). In the interval zero to $60 \mathrm{ft}$ within this one well, ${ }^{137} \mathrm{Cs}$ concentrations decrease by a factor of 10 per each $20 \mathrm{ft}$ of depth. From the integral equation, an expression was developed describing concentration through a given plume volume as a function of the maximum concentration, $\mathrm{C}_{\mathrm{o}}$, at the upper surface. Since the total inventories are given, values of $\mathrm{C}_{0}$ can be calculated from this expression. Additional details of this procedure are provided in Appendix A. The results are reproduced in Table 4.2. 
Table 4.2. Surface Soil ${ }^{137} \mathrm{Cs}$ and ${ }^{90} \mathrm{Sr}$ Concentrations $\left(C_{0}\right)$ for Leakage Cases (in $\mathrm{nCi} / \mathrm{g}$ )

\begin{tabular}{|c|c|c|c|c|}
\hline \multirow{2}{*}{} & \multicolumn{2}{|c|}{8,000 Gallon Leak } & \multicolumn{2}{c|}{40,000 Gallon Leak } \\
\cline { 2 - 5 } & Sr-90 & Cs-137 & Sr-90 & Cs-137 \\
\hline AX-101 & 2,139 & 1,130 & 4,252 & 2,248 \\
\hline AX-102 & 5,323 & 2,262 & 10,585 & 4,498 \\
\hline AX-103 & 45,594 & 1,990 & 90,658 & 3,956 \\
\hline AX-104 & 62,608 & 1,299 & 124,489 & 2,582 \\
\hline
\end{tabular}

\subsection{SCOPING ESTIMATES OF DOSE RATES FROM LEAKAGE PLUMES}

Based on the values in Table 4.2, scoping estimates of surface dose rates were developed for the various leakage cases. The results of these calculations are listed in Table 4.3.

Table 4.3. Estimated Dose Rates 1 meter Above the Center of Specified Leakage Volumes and Sources (in $\mathrm{mrem} / \mathrm{hr}$ )

\begin{tabular}{|c|c|c|c||c|c|c|}
\hline & \multicolumn{3}{|c||}{8,000 Gallon Leak } & \multicolumn{3}{c|}{40,000 Gallon Leak } \\
\cline { 2 - 7 } & Sr-90 & Cs-137 & Total & Sr-90 & Cs-137 & Total \\
\hline \hline AX-101 & 18 & 656 & 674 & 37 & 1348 & 1385 \\
\hline AX-102 & 45 & 1312 & 1357 & 92 & 2698 & 2790 \\
\hline AX-103 & 382 & 1154 & 1536 & 785 & 2373 & 3158 \\
\hline AX-104 & 524 & 753 & 1277 & 1078 & 1549 & 2627 \\
\hline
\end{tabular}

Based on the estimates in Table 4.3, the worst-case scenarios involve leakage from Tank AX103 , followed closely by Tank AX-102. The worst-case dose rate from an 8,000-gal leak is about $1.5 \mathrm{rem} / \mathrm{hr}$; the worst-case dose rate from a 40,000 -gal leak is about $3 \mathrm{rem} / \mathrm{hr}$.

\subsection{WORKER DOSE CONSEQUENCES FROM LEAKAGE SCENARIOS}

Because of limited time and resources, the spatial variation of worker exposures from 8,000 -gal and 40,000-gal plume sources could not be evaluated by numerical modeling (MCNP program) as was done to support various aspects of conceptualization of tank removal (see Appendix A). However, because the source term for the 8,000-gal leak is nearly the same as the source term for the one percent residual inventory in Tank AX-101 when the dome is removed, the previous 
modeling work can be used to make some inferences about worker dose consequences from leakage.

Figure 4.1 shows 8,000-gal and 40,000-gal plume sources drawn on the floor of the pit excavation at selected locations. At Location A, the plumes are centered on the northwest edge of tank AX-103. At Location B, the plumes are centered on the southeast edge of the same tank. For that particular tank, Location A defines a maximum exterior plume configuration, while Location $\mathrm{B}$ is most interior. There are opposite configurations for the other three tanks. From the standpoint of worker doses, Configuration $A$ is least adverse and Configuration B is most adverse. As long as workers are not directly over the plume areas, the aggregate effect of the plume sources at $A$ and $B$ is to raise local background within the pit excavation. ROM estimates are listed in Table 4.4 .

Table 4.4. ROM Estimates of Increases in Local Background in the Pit Excavation due to Leakage ( $\mathrm{mrem} / \mathrm{hr}$ )

\begin{tabular}{||l|c|c|}
\hline & Location A & Location B \\
\hline $\begin{array}{l}\text { 8,000-gal leakage source } \\
\text { from AX-103 }\end{array}$ & 10 & 20 \\
\hline $\begin{array}{l}\text { 40,000-gal leakage source } \\
\text { from AX-103 }\end{array}$ & 20 & 40 \\
\hline
\end{tabular}

The increases in local background do not translate into significant increases in doses to tank removal workers, because all workers inside the pit would be enclosed in heavily shielded cabs with dose reduction factors (DRF) of between 100 and 1,000 .

If equipment operators would be required to work directly over a plume source to accomplish base slab removal (i.e., the final tank removal activity), then worker dose estimates would rise sharply. Based on the data listed for tank AX-101 in Table 8 of Appendix A, an excavator operator in a cab with a DRF of 1,000 would get an additional 10 or 20 mrem dose per day. This is about the same as the estimated incremental dose rate from the radiological source in base slab debris.

It should be reiterated that these are ROM estimates that have been produced with virtually no hard information. The dose calculations are sensitive to several different input parameters (e.g., inventories, concentration gradients, $\mathrm{C}_{0}$ estimates, task durations). Credibility of these estimates is speculative. 
Figure 4.1. Pit Excavation with Hypothetical Leak Plume Locations

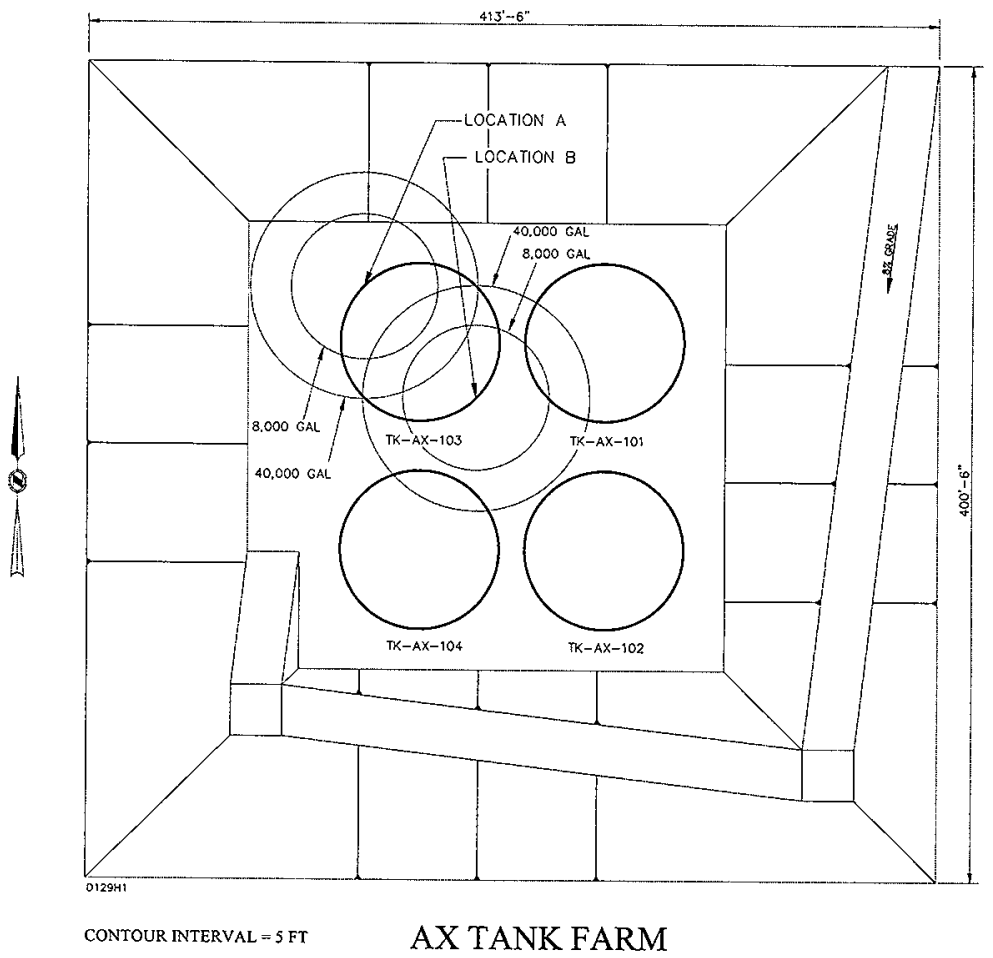




\subsection{CONSTRUCTIBILITY IMPACTS FROM LEAKAGE SCENARIOS}

Depending on the size and location of the leakage plume, the pit excavation may have to be enlarged. From the standpoint of constructibility, leakage Location B in Figure 4.1 would produce the least impact. Leakage locations toward the perimeter of the excavation would require some amount of additional excavation. Location $\mathrm{A}$ is the most adverse position because it would require the pit to be extended in two directions. Enlargement of the pit in the east-west direction would carry the additional liability of increasing the span of the trusses of the enclosure structure. Estimates of additional soil volumes to be excavated, modifications to the enclosure strucure, resource utilization, emissions, manning, and schedule impacts (if any) cannot be made with the leakage location undefined.

The additional radiological source in the pit floor could increase shielding requirements for mobile equipment items working inside the pit. It is likely that additional shielding would have to be placed underneath the cabs of the two excavators and the wheel loader, because these units would have to work directly over the leak source term at certain times during the operation. For base slab removal without the leakage source term, the front and sides of the cabs require the heaviest protection.

If a leakage plume is uncovered during tank removal, additional shielding clearly would be required for the container trucks. The trucks in the equipment spread for the tank removal concept are based on 20-ton container trucks in current use at ERDF. When all shielding requirements are fully accounted for, the suspension ratings of the container trucks working inside the enclosure would have to increase. It is possible that they would have to be reconceptualized as adaptations of off-road haul trucks with suspensions rated for at least 50 tons, such as the Caterpillar 773B.

With increased shielding of mobile equipment items as necessary, and based on the ROM dose assessments discussed in the previous subsection, it appears that tank removal could be performed in the presence of a leakage plume without any other modification to the concept operation described in Section 3.0. However, a modest upward revision in the radiological source term estimates for the leakage scenarios could easily raise annual doses for maximally exposed workers (equipment operators and/or teamsters) beyond the $1,500 \mathrm{mrem} / \mathrm{yr}$ study criterion. 


\subsection{REFERENCES}

Caggiano, J.A., and S.M. Goodwin, 1991, Interim Status Groundwater Monitoring Plan for the Single-Shell Tanks, WHC-SD-EN-AP-012, Westinghouse Hanford Company, Richland, Washington.

CEES, 1997. Report of Best-Estimate Past Release Vadose Zone Contamination of the 241-AX Tank Farm (Rev. 1), Columbia Energy and Environmental Services, Inc., Richland, Washington.

DOE, 1980. Decommissioning Handbook, prepared by Nuclear Energy Services, Inc., Danbury, Conn., DOE/EV/10128-1, U.S. Department of Energy, Washington, D.C.

DOE, 1992. Purex Plant Source Aggregate Area Management Study Report, DOE/RL-92-04. U. S. Department of Energy, Richland, Washington.

DOE-GJO, 1997. Vadose Zone Characterization Project at the Hanford Tank Farms, AX Tank Farm Preliminary Report, GJO-HAN-10, U. S. Department of Energy, Richland Operations Office, Richland, Washington, April.

Ecology, EPA, and DOE, 1994, Hanford Federal Facility Agreement and Consent Order, as amended, Washington State Department of Ecology, U.S. Environmental Protection Agency, and U.S. Department of Energy, Olympia, Washington.

EPA 451/R-93-004, "Estimation of Air Impacts from Area Sources of Particulate Matter Emissions at Superfund Sites," Report ASF-32.

Hertzel, J.S., 1997. Letter Report, Maximum and Minimum Tank Leakage Volumes, Internal Memo 8C460-97-001, Numatec Hanford Corporation, Richland, Washington.

HSRCM, 1994. Hanford Site Radiological Control Manual, HSRCM-1, Fluor Daniel Hanford Inc., Richland, Washington.

IAEA, 1988. Decontamination and Demolition of Concrete and Metal Structures During the Decommissioning of Nuclear Facilities, Tech. Report No. 286, International Atomic Energy Agency, Vienna, Austria.

JEG, 1997. Hanford Tanks Initiative, Retrieval Performance Evaluation Criteria Assessment: Work Plan, Jacobs Engineering Group, Kennewick, Washington.

Kline, P.L., H. Hampt, and W.A. Skelly, 1995. Closure Technical Data Package for the Tank Waste Remediation System Environmental Impact Statement, WHC-SD-WM-EV-107, Westinghouse Hanford Company, Richland, Washington.

Lindsey, K.A., 1993, Memorandum to G.D. Bazinet with attached Letter Report, Geohydrologic Setting, Flow, and Transport Parameters for Single Shell Tank Farms, K.A. Lindsey and A.G. Law, 81231-93-060, Westinghouse Hanford Company, Richland, Washington. 
Lowe, S.S. 1993. Engineering Study of Tank Leaks Related to Hydraulic Retrieval of Sludge from Tank 241-C-106, WHC-SD-WM-ES-218, Westinghouse Hanford Company, Richland, Washington.

McConville, C.M., 1995. In-Situ Treatment and Disposal of Radioactive Waste in Hanford Site Underground Storage Tanks Engineering Data Package for the Tank Waste Remediation System Environmental Impact Statement, WHC-SD-WM-EV-101, Westinghouse Hanford Company, Richland, Washington.

Piepho, M.G., et. al., 1996. Sensitivity Analysis of Sluicing-Leak Parameters for the 241-AX Tank Farm, WHC-SD-WM-ANAL-052, Westinghouse Hanford Company, Richland Washington.

Price, W.H. and K.R. Fecht, 1976b, Geology of the 24I-AX Tank Farm, ARH-LD-128, Atlantic Richfield Hanford Company, Richland, Washington.

COGEMA Engineering, 1997a. AX Tank Farm Waste Inventory Study for the Hanford Tanks Initiative (HTI) Project, COGEMA-EN-RPT-002, SGN Eurisys Services Corp., Richland, Washington.

COGEMA Engineering, 1997b. Soil Remediation Engineering Study, COGEMA-EN-RPT-004, SGN Eurisys Services Corp., Richland, Washington.

WACA, 1997. Suggested Specifications for Controlled Density Fill, Washington Aggregates and Concrete Association, Seattle, Washington.

WHC, 1995. Radioactive Hazardous Materials Packaging Directory, Rev. 1, WHC-SP-1070, Westinghouse Hanford Company, Richland Washington. 
HNF-3378-Rev. 0

APPENDIX A

DOSE RATE ESTIMATES FOR AX TANK FARM REMEDIATION

Provided by Paul D. Rittman Ph.D. CHP

Flour Daniel Northwest, Inc.

September 1998 


\section{CONTENTS}

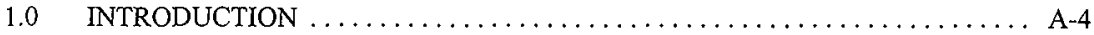

2.0 MCNP - GEOMETRY PREPARATION $\ldots \ldots \ldots \ldots \ldots \ldots \ldots \ldots \ldots \ldots$ A-4

3.0 MCNP -- SOURCE DEFINITION $\ldots \ldots \ldots \ldots \ldots \ldots \ldots \ldots \ldots \ldots \ldots \ldots \ldots \ldots$

4.0 MCNP - DETECTOR LOCATIONS $\ldots \ldots \ldots \ldots \ldots \ldots \ldots \ldots \ldots \ldots \ldots \ldots \ldots \ldots$

5.0 MCNP -. DOSE RATE RESULTS $\ldots \ldots \ldots \ldots \ldots \ldots \ldots \ldots \ldots \ldots \ldots \ldots \ldots \ldots$

6.0 ISO-PC - DEBRIS EXCAVATION $\ldots \ldots \ldots \ldots \ldots \ldots \ldots \ldots \ldots \ldots \ldots \ldots \ldots \ldots \ldots$

7.0 ISO-PC -- SHIPPING CONTAINER DESIGN $\ldots \ldots \ldots \ldots \ldots \ldots \ldots \ldots \ldots$

8.0 DOSE RATE ESTIMATES FOR THE POSTULATED 241-AX TANK LEAKS - A-19

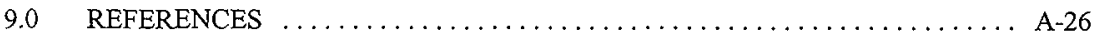

\section{FIGURES:}

1. Four Tank Case -- Domes Intact, East-West Plane Through Tanks 103 and 101 . . A-Att1-2

2. Four Tank Case -- Domes Intact, East-West Plane Through Tank 101 ........ A-Att1-3

3. Four Tank Case -- Domes Intact, East-West Plane Through Tanks 103 and 101 . . A A-Att1-4

4. Four Tank Case -- Tank Wall/Base Corner, East-West Plane Through Tank 101 ... A-Attl-5

5. Four Tank Case -- Tank Wall/Base Corner, East-West Plane Through Tank 101 . . A A-Att1-6

6. Four Tank Case -- Dome Removed from AX-101, Plane Through

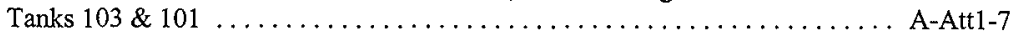

7. SABRINA 3-D Sketch of the Four Tank Case with AX-101 Dome Removed ..... A-Att1-8

\section{TABLES:}

1. Ellipsoids Which Represent 241-AX Tank Domes ................... A-5

2. Comparison of Dome Dimensions with MCNP Model $\ldots \ldots \ldots \ldots \ldots \ldots \ldots \ldots$ A-5

3. Assumed Composition of Air, Soil, and Concrete $\ldots \ldots \ldots \ldots \ldots \ldots \ldots \ldots \ldots$ A-6

4. Residual Tank Waste Elemental Composition ...................... A-7

5. Residual Radionuclide Inventory (Assumes 99 Percent Retrieved) . . . . . . . . . A A-8

6. Total Photon Production Rates $(99$ Percent Retrieval) . . . . . . . . . . . . . . . . A -9

7. Dose Rates $(\mathrm{mrem} / \mathrm{h})$ After Excavation - 99 Percent Retrieval . . . . . . . . . . . . A-1 1

8. Total Dose Rates (mrem/h) with a Tank Dome Removed (99 percent) . . . . . . . . . A-12

9. Dose Rates (mrem $/ \mathrm{h})$ After Excavation -- 99.9 Percent Retrieval . . . . . . . . . . . A-13

10. Total Dose Rates $(\mathrm{mrem} / \mathrm{h})$ with a Tank Dome Removed $(99.9$ Percent) $\ldots \ldots \ldots$. . A-14

11. Single Tank Dose Rates (mrem/h) After Excavation .................. A-15

12. Single Tank Dose Rates $(\mathrm{mrem} / \mathrm{h})$ With Dome Removed $\ldots \ldots \ldots \ldots \ldots \ldots \ldots$ A-16

13. Dose Rates $(\mathrm{mrem} / \mathrm{h})$ During Debris Removal $\ldots \ldots \ldots \ldots \ldots \ldots \ldots \ldots \ldots \ldots \ldots \ldots \ldots$

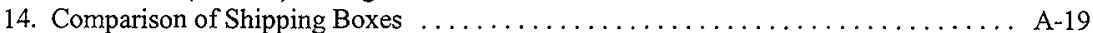

15. Four Tank Case -- Dome Intact, AX-101 Source ...............A.Att2-2 


\section{CONTENTS (cont'd)}

\section{TABLES (cont'd):}

16. Four Tank Case -- Dome Removed, AX-103 Source A-Att2-8

17. Single Tank Case -- Dome Intact, $\mathrm{AX}-101$ Source, $70.5 \mathrm{lb} / \mathrm{ft}^{3}$ Grout A-Att2-13

18. Single Tank Case -- Dome Removed, AX-102 Source, $211.5 \mathrm{lb} / \mathrm{ft}^{3}$ Grout A-Att2-17

19. MCNP Dose Rates 3 Feet Above Surfaces With Soil Removed from Tank Domes -- 99 Percent Retrieval A-Att3-2

20. MCNP Dose Rates 3 Feet Above Surfaces With a Tank Dome Removed -- 99 Percent Retrieval

21. Single Tank Dose Rates After Excavation (Dome Intact) - 99 Percent Retrieval . A A-Att3-6

22. Single Tank Dose Rates With Dome Removed -- 99 Percent Retrieval . . . . . . . A-Att3-8

23. $4 \mathrm{~m}^{2}$ Source Representing Exposed Tank Bottom ................. A-Att4-2

24. $4 \mathrm{~m}^{2}$ Source Representing Debris Removal -- 2 inches of Iron Shielding . . . . . . A-Att4-4 25. ISO-PC Input File for Shipping Container Design $\ldots \ldots \ldots \ldots \ldots \ldots \ldots$ A-Att $4-6$ 


\subsection{INTRODUCTION}

During the remediation of the 241-AX Tank Farm various potentially high dose rate situations will be encountered. The purpose of this report is to estimate dose rates for those situations. The first concern is the dose rates near the 241-AX Tank Farm while uncovering the tank domes and removing them. The MCNP program (Carter 1996) was used for these calculations since it handles air-scattered radiation accurately. The second concern is operator dose during the tank demolition. The ISO-PC program (Rittmann 1996) was used for these calculations because of the simple arrangements of source and dose point.

The MCNP program requires input files with three main parts. The first is the geometry of the facility. This includes the sizes and shapes and locations and composition of the various objects in the 241-AX Tank Farm. The second part of the input is the location and strength of the radiation sources. The third part of the input is the location of the detector points. Each of these is described separately below.

The ISO-PC calculations are presented for debris removal and shipping container design. Note that the English system of units was used for simplicity and congruence with the engineered drawings for 241-AX Tank Farm.

\subsection{MCNP -- GEOMETRY PREPARATION}

The position, shape, size, and composition of the various objects in the 241-AX Tank Farm was determined from engineering drawings. It was assumed that all dome penetrations were capped, and concrete structures above the dome were removed. The assumed excavation removes just enough soil above the four tanks to the outer edge of the tanks. The rectangular excavation has sloping walls.

The tops of the domes are assumed to be 6 feet below the surrounding soil surface. The excavation depth which exposes the tank domes completely is assumed to be $13 \mathrm{ft} 9 \mathrm{in}$. The excavation has sloping walls at 1.5 to 1 . The base of the excavation is $15 \mathrm{ft}$ from the nearest edge of the tanks on all four sides.

The tank farm dose rates were analyzed for 13 geometries: (1) all four tank domes uncovered,

(2) all four tank domes uncovered and one dome is removed (4 cases -- one for each tank),

(3) one tank uncovered with four thicknesses of grout over the waste (4 cases -- one for each thickness), and (4) one tank uncovered and its dome removed with four thicknesses of grout over the waste ( 4 cases $\cdots$ one for each thickness).

The geometry models were developed in spreadsheets to facilitate unit conversions and other calculations. The spreadsheets took longer to set up initially, but changes to the input were readily accommodated.

The tanks have an inside diameter of $75 \mathrm{ft} 1 \mathrm{in}$., an inside height of $44 \mathrm{ft} 6 \mathrm{in}$., and a concrete dome thickness at the center of $15 \mathrm{in}$. The outside diameter is $77 \mathrm{ft} 7 \mathrm{in}$. The increase to a 
diameter of $79 \mathrm{ft} 1 \mathrm{in}$. at $25 \mathrm{ft}$ above the tank bottom was not modeled, since this location is well below the bottom of the excavation.

Tank domes were modeled as ellipsoids which approximate the dimensions given on drawing $\mathrm{H}-2-44562$. The inner and outer ellipsoid dimensions are given in Table 1 below. The vertical position of the surfaces was arranged to match the drawing dimensions at the center of the tank. The drawing shape and the ellipsoid model are compared in Table 2. The largest difference ( 3 in.) occurs at $3 \mathrm{ft}$ inside the inner tank wall, where the dome has a vertical thickness of about 39 in. while the ellipsoid model gives a thickness of 36 in.

Table 1. Ellipsoids Which Represent 241-AX Tank Domes

\begin{tabular}{|l|c|c|}
\hline & Semi-Major Axis & Semi-Minor Axis \\
\hline Upper Surface & $56 \mathrm{ft} 7$ in. & $28 \mathrm{ft} 3$ in. \\
\hline Lower Surface & $37 \mathrm{ft} 7 \mathrm{in}$. & $12 \mathrm{ft} 7$ in. \\
\hline
\end{tabular}

Table 2. Comparisou of Dome Dimensions with MCNP Model

\begin{tabular}{|c|c|c|c|}
\hline \multicolumn{4}{|c|}{ Surface Height Read from Drawing H-2-44562 } \\
\hline Radial Position & Lower Surface & Upper Surface & Thickness \\
\hline $\begin{array}{l}0 \mathrm{ft} 0.00 \mathrm{in} . \\
13 \mathrm{ft} 0.00 \mathrm{in} . \\
26 \mathrm{ft} 0.00 \mathrm{in} . \\
30 \mathrm{ft} 6.50 \mathrm{in} . \\
32 \mathrm{ft} 6.50 \mathrm{in} . \\
34 \mathrm{ft} 6.50 \mathrm{in} . \\
36 \mathrm{ft} 6.50 \mathrm{in} . \\
36 \mathrm{ft} 6.75 \mathrm{in} . \\
37 \mathrm{ft} 6.50 \mathrm{in} . \\
38 \mathrm{ft} 9.50 \mathrm{in} .\end{array}$ & $\begin{array}{l}12 \mathrm{ft} 0.00 \mathrm{in} . \\
11 \mathrm{ft} 3.38 \mathrm{in} . \\
8 \mathrm{ft} 6.81 \mathrm{in} . \\
6 \mathrm{ft} 7.88 \mathrm{in} . \\
5 \mathrm{ft} 5.78 \mathrm{in} . \\
4 \mathrm{ft} 0.38 \mathrm{in} . \\
2 \mathrm{ft} 1.88 \mathrm{in} . \\
2 \mathrm{ft} 3.75 \mathrm{in} . \\
0 \mathrm{ft} 0.00 \mathrm{in} . \\
0 \mathrm{ft} 0.00 \mathrm{in} .\end{array}$ & $\begin{array}{l}13 \mathrm{ft} 3.00 \mathrm{in} . \\
12 \mathrm{ft} 6.50 \mathrm{in} . \\
10 \mathrm{ft} 1.81 \mathrm{in} . \\
8 \mathrm{ft} 8.63 \mathrm{in.} \\
8 \mathrm{ft} 0.38 \mathrm{in} . \\
7 \mathrm{ft} 3.38 \mathrm{in} . \\
6 \mathrm{ft} 5.63 \mathrm{in} . \\
6 \mathrm{ft} 5.63 \mathrm{in.} \\
6 \mathrm{ft} 1.00 \mathrm{in} . \\
5 \mathrm{ft} 6.38 \mathrm{in} .\end{array}$ & $\begin{array}{l}15.000 \mathrm{in} . \\
15.125 \mathrm{in.} \\
19.000 \mathrm{in} . \\
24.750 \mathrm{in} . \\
30.600 \mathrm{in} . \\
39.000 \mathrm{in} . \\
51.750 \mathrm{in} . \\
49.875 \mathrm{in} . \\
73.000 \mathrm{in} . \\
66.375 \mathrm{in} .\end{array}$ \\
\hline \multicolumn{4}{|c|}{ Surface Height Computed Using Ellipsoid Model } \\
\hline Radial Position & Lower Surface & Upper Surface & Thickness \\
\hline $\begin{array}{l}0 \mathrm{ft} 0.00 \mathrm{in.} \\
13 \mathrm{ft} 0.00 \mathrm{in} . \\
26 \mathrm{ft} 0.00 \mathrm{in} . \\
30 \mathrm{ft} 6.50 \mathrm{in.} \\
32 \mathrm{ft} 6.50 \mathrm{in} . \\
34 \mathrm{ft} 6.50 \mathrm{in} . \\
36 \mathrm{ft} 6.50 \mathrm{in} . \\
36 \mathrm{ft} 6.75 \mathrm{in} . \\
37 \mathrm{ft} 6.50 \mathrm{in} . \\
38 \mathrm{ft} 9.50 \mathrm{in} .\end{array}$ & $\begin{array}{l}12 \mathrm{ft} 0.00 \mathrm{in} . \\
11 \mathrm{ft} 2.68 \mathrm{in} . \\
8 \mathrm{ft} 6.04 \mathrm{in} . \\
6 \mathrm{ft} 9.00 \mathrm{in} . \\
5 \mathrm{ft} 8.54 \mathrm{in} . \\
4 \mathrm{ft} 4.51 \mathrm{in} . \\
2 \mathrm{ft} 4.30 \mathrm{in} . \\
2 \mathrm{ft} 3.95 \mathrm{in} . \\
0 \mathrm{ft} 0.11 \mathrm{in} . \\
0 \mathrm{ft} 0.00 \mathrm{in} .\end{array}$ & $\begin{array}{l}13 \mathrm{ft} 3.00 \mathrm{in} . \\
12 \mathrm{ft} 5.93 \mathrm{in} . \\
10 \mathrm{ft} 1.09 \mathrm{in} . \\
8 \mathrm{ft} 9.38 \mathrm{in} . \\
8 \mathrm{ft} 1.33 \mathrm{in} . \\
7 \mathrm{ft} 4.50 \mathrm{in} . \\
6 \mathrm{ft} 6.83 \mathrm{in} . \\
6 \mathrm{ft} 6.72 \mathrm{in} . \\
6 \mathrm{ft} 1.64 \mathrm{in} . \\
5 \mathrm{ft} 6.80 \mathrm{in} .\end{array}$ & $\begin{array}{l}15.000 \text { in. } \\
15.253 \text { in. } \\
19.056 \text { in. } \\
24.378 \text { in. } \\
28.783 \text { in. } \\
35.996 \text { in. } \\
50.524 \text { in. } \\
50.768 \text { in. } \\
73.531 \text { in. } \\
66.795 \text { in. }\end{array}$ \\
\hline \multicolumn{4}{|c|}{$\begin{array}{l}\text { Note: Surface Heights are measured from the Tangent Line at } 690.92 \mathrm{ft} \\
\text { elevation. Dome thicknesses are measured along a vertical line. }\end{array}$} \\
\hline
\end{tabular}


Sketches of the geometry models are shown in Appendix A. Appendix B gives listings of selected input files. The coordinate system origin for the four tank cases is the center of the tank farm. The coordinate system origin for the single tank cases to evaluate grout shielding effectiveness is the center of the tank. In all cases the vertical position of the origin is an elevation of $680 \mathrm{ft} 2 \mathrm{in}$. above sea level, which is the approximate level of the soil surrounding the 241-AX Tank Farm.

Composition of the air, soil, concrete and waste solids are shown in Table 3 . The air composition comes from ANSI/ANS-6.4.3-1991. The soil composition was determined from an average of Hanford surface soils (Brown 1992). The concrete composition is typical of that used at Hanford (Carter 1983).

Table 3. Assumed Composition of Air, Soil, and Concrete

\begin{tabular}{|l|c|c|c|}
\hline \multirow{2}{*}{ Element } & \multicolumn{3}{|c|}{ Mass Fractions, percent } \\
\cline { 2 - 4 } & Air & Soil & Concrete \\
\hline Hydrogen & 0.048 & 0.62 & 0.31 \\
Carbon & 0.014 & & \\
Nitrogen & 75.191 & & 44.07 \\
Oxygen & 23.464 & 47.33 & 1.82 \\
Sodium & & 1.68 & 3.76 \\
Magnesium & & 2.72 & 6.07 \\
Aluminum & & 6.86 & 21.57 \\
Silicon & & 22.89 & 0.09 \\
Phosphorus & & 0.22 & 0.09 \\
Sulfur & 1.282 & & 13.06 \\
Argon & & 1.07 & 0.49 \\
Potassium & & 5.97 & 0.13 \\
Calcium & & 1.43 & 7.88 \\
Titanium & & 9.15 & 0.66 \\
Manganese & & 9.06 & $2.258 \mathrm{~g} / \mathrm{cc}^{3}$ \\
Iron & & $141 \mathrm{lb} / \mathrm{ft}^{3}$ \\
Krypton & & $1.80 \mathrm{~g} / \mathrm{cc}^{3}$ & $\mathrm{~g}$ \\
\hline Density: & $0.0012 \mathrm{~g} / \mathrm{cc}$ & $112 \mathrm{lb} / \mathrm{ft}^{3}$ & \\
\hline
\end{tabular}

Tank waste was modeled as a three inch thick layer on the bottom of the tank. Self-attenuation is minimal. However, tank compositions are needed to give a credible estimate for the amount of bremsstrahlung radiation emitted by the beta rays within the waste.

Composition of the tank waste is based on information given in the documents which summarize the estimated tank contents after retrieval operations are completed. The case where 99 percent 
has been removed is used for both the waste composition and the total radionuclide content. Water is assumed to be present to complete the missing weight fractions. The assumed compositions are shown in Table 4.

Table 4. Residual Tank Waste Elemental Composition

\begin{tabular}{|l|c|c|c|}
\hline Element & Tank AX-101 & Tank AX-102 & AX-103 \& AX-104 \\
\hline Hydrogen & 3.811 & 4.722 & 4.722 \\
Carbon & 3.390 & 1.731 & 0.0 \\
Nitrogen & 22.079 & 3.693 & 0.213 \\
Oxygen & 42.709 & 64.925 & 62.394 \\
Sodium & 15.815 & 7.560 & 4.262 \\
Magnesium & 0.0 & 0.0 & 0.229 \\
Aluminum & 2.778 & 3.093 & 3.706 \\
Silicon & 1.014 & 2.249 & 3.875 \\
Phosphorus & 1.038 & 0.147 & 0.583 \\
Sulfur & 0.468 & 0.209 & 0.719 \\
Chlorine & 0.828 & 0.075 & 0.0 \\
Potassium & 0.300 & 0.018 & 0.0 \\
Calcium & 0.162 & 0.506 & 1.455 \\
Chromium & 0.744 & 0.015 & 0.174 \\
Manganese & 0.282 & 0.762 & 0.256 \\
Iron & 1.704 & 9.060 & 16.404 \\
Nickel & 0.048 & 0.344 & 0.850 \\
Krypton & 0.102 & 0.0 & 0.0 \\
Barium & 0.094 & 0.0 & 0.158 \\
Lead & 0.234 & 0.0 & 0.0 \\
Uranium & 2.400 & 0.890 & 0.0 \\
\hline Note: Values shown are percent by weight for the 99 percent retrieval. \\
\hline
\end{tabular}

The hole in the dome (representing dome removal) was modeled using a conical surface. The apex of the cone is $120 \mathrm{ft}$ below the original ground surface. The cone angle is 19.606 degrees. This produces an opening which effectively eliminates the dome.

Concrete represents grout shielding in the tanks, since its composition is similar to that of grout. Since the grout density is not known precisely, the shielding thicknesses are given in terms of areal density $\left(\mathrm{lb} / \mathrm{ft}^{2}\right)$. Lower density grouts will require greater thicknesses to achieve the same attenuation factor.

Additional surfaces were placed inside the domes and the tank wall and base to improve the monte carlo calculation efficiency. 


\subsection{MCNP -- SOURCE DEFINITION}

The actual radiation source was the three inch thick layer on the bottom of the tank, but the radius only extended to three feet from the inner tank wall.

The radionuclide composition of the tank waste is based on information given in the documents which summarize the estimated tank contents after retrieval operations are completed. The case where 99 percent has been removed is used for both the waste composition and the total radionuclide content. The assumed compositions are shown in Table 5. A complete listing of all source input for MCNP is found in Appendix B.

Table 5. Residual Radionuclide Inventory (Assumes 99 Percent Retrieved)

\begin{tabular}{|l|c|c|c|c|}
\hline Nuclide & AX-101 & AX-102 & AX-103 & AX-104 \\
\hline Co-60 & 2.2 & & 61.7 & 61.7 \\
Sr-90 & 7238 & 82340 & 527850 & 527850 \\
Y-90 & 7238 & 82340 & 527850 & 527850 \\
Tc-99 & 1.7 & 3.8 & 2.02 & 1.83 \\
Sb-125 & & & 25.7 & 25.7 \\
Te-125m & & & 6.30 & 6.30 \\
Cs-137 & 1684 & 11195 & 10820 & 10820 \\
Ba-137m & 1593 & 10590 & 10236 & 10236 \\
Sm-151 & 0.05 & 1480 & 2250 & 4000 \\
Eu-154 & & & 449 & 449 \\
Eu-155 & & & 351 & 351 \\
\hline
\end{tabular}

The photon spectra were generated using the ISO-PC program (Rittmann 1996). The input file used to generate these spectra is included in Appendix B. The photon spectra are shown in Table 6. Since the spectra for AX-103 and AX-104 are identical, only one was used in the dose rate calculations.

Since nearly all of the photons which are significant in producing the final dose rate come from the $0.66 \mathrm{MeV}$ group (Cs-137), the first two and the last energy groups were omitted from the calculation. The two low energy groups are quickly attenuated, for example, the $24.6 \mathrm{keV}$ group has a relaxation length in air of about $50 \mathrm{ft}$. The highest energy group has comparatively few photons.

For the 99.9 percent retrieval case, it happens that the projected residual activities are one-tenth of the 99 percent retrieval case used in the dose rate calculations. Therefore, all of the 99.9 percent dose rates are one-tenth of the 99 percent dose rates. 
HNF-3378-Rev. 0

Table 6. Total Photon Production Rates (99 Percent Retrieval)

\begin{tabular}{|c|c|c|c|c|c|}
\hline \multicolumn{2}{|c|}{$\begin{array}{l}\text { Tank AX-101 } \\
\mathrm{MeV} \text { photon/s }\end{array}$} & \multicolumn{2}{|c|}{$\begin{array}{l}\text { Tank AX-102 } \\
\mathrm{MeV} \text { photon/s }\end{array}$} & \multicolumn{2}{|c|}{$\begin{array}{c}\mathrm{AX}-103 / 104 \\
\mathrm{MeV} \text { photon/s }\end{array}$} \\
\hline 0.0143 & $8.32 \mathrm{E}+12$ & 0.0143 & $8.96 \mathrm{E}+13$ & 0.0142 & $6.02 E+14$ \\
\hline 0.0246 & $4.36 \mathrm{E}+12$ & 0.0246 & $4.69 \mathrm{E}+13$ & 0.0246 & $3.15 \mathrm{E}+14$ \\
\hline 0.0336 & $6.95 \mathrm{E}+12$ & 0.0338 & $5.72 \mathrm{E}+13$ & 0.0344 & $2.20 \mathrm{E}+14$ \\
\hline 0.0447 & $1.82 \mathrm{E}+12$ & 0.0447 & $1.97 \mathrm{E}+13$ & 0.0447 & $1.40 \mathrm{E}+14$ \\
\hline 0.0548 & $1.33 \mathrm{E}+12$ & 0.0548 & $1.44 \mathrm{E}+13$ & 0.0548 & $9.64 \mathrm{E}+13$ \\
\hline 0.0649 & $1.13 E+12$ & 0.0649 & $1.22 \mathrm{E}+13$ & 0.0649 & $8.25 E+13$ \\
\hline 0.0749 & $1.03 \mathrm{E}+12$ & 0.0749 & $1.11 \mathrm{E}+13$ & 0.0749 & $7.49 \mathrm{E}+13$ \\
\hline 0.0849 & $9.29 \mathrm{E}+11$ & 0.0849 & $1.01 \mathrm{E}+13$ & 0.0850 & $7.21 E+13$ \\
\hline 0.0949 & $8.35 \mathrm{E}+11$ & 0.0949 & $9.08 \mathrm{E}+12$ & 0.0949 & $6.14 \mathrm{E}+13$ \\
\hline 0.1379 & $4.18 \mathrm{E}+12$ & 0.1380 & $4.55 E+13$ & 0.1374 & $3.17 \mathrm{E}+14$ \\
\hline 0.2433 & $1.30 \mathrm{E}+12$ & 0.2433 & $1.42 \mathrm{E}+13$ & 0.2434 & $9.68 \mathrm{E}+13$ \\
\hline 0.3450 & $6.30 \mathrm{E}+11$ & 0.3450 & $6.90 \mathrm{E}+12$ & 0.3450 & $4.66 \mathrm{E}+13$ \\
\hline 0.4663 & $4.81 \mathrm{E}+11$ & 0.4663 & $5.29 \mathrm{E}+12$ & 0.4659 & $3.61 \mathrm{E}+13$ \\
\hline 0.6615 & $5.33 \mathrm{E}+13$ & 0.6614 & $3.56 \mathrm{E}+14$ & 0.6606 & $3.68 \mathrm{E}+14$ \\
\hline 0.8179 & $1.07 \mathrm{E}+11$ & 0.8179 & $1.18 \mathrm{E}+12$ & 0.8303 & $1.02 \mathrm{E}+13$ \\
\hline 0.9869 & $7.30 \mathrm{E}+10$ & 0.9870 & $8.10 \mathrm{E}+11$ & 0.9939 & $1.01 \mathrm{E}+13$ \\
\hline 1.2437 & $2.01 E+11$ & 1.2039 & $4.21 \mathrm{E}+11$ & 1.2514 & $1.35 \mathrm{E}+13$ \\
\hline 1.4499 & $1.26 \mathrm{E}+10$ & 1.4500 & $1.41 \mathrm{E}+11$ & 1.4989 & $1.51 \mathrm{E}+12$ \\
\hline 1.7412 & $1.20 \mathrm{E}+10$ & 1.7415 & $1.36 \mathrm{E}+11$ & 1.7411 & $8.77 \mathrm{E}+11$ \\
\hline 1.8695 & $6.44 \mathrm{E}+08$ & 1.8695 & $7.25 \mathrm{E}+09$ & 1.8694 & $4.72 \mathrm{E}+10$ \\
\hline 2.1681 & $4.29 \mathrm{E}+08$ & 2.1682 & $4.88 \mathrm{E}+09$ & 2.1680 & $3.13 E+10$ \\
\hline 2.2000 & $7.98 \mathrm{E}+05$ & 2.2000 & $9.02 \mathrm{E}+06$ & 2.2000 & $5.84 \mathrm{E}+07$ \\
\hline
\end{tabular}

\subsection{MCNP -- DETECTOR LOCATIONS}

Point detectors were used for the dose rate tallies. These tallies were converted to $\mathrm{mrem} / \mathrm{h}$ using the flux to dose equivalent factors in ANSI/ANS-6.1.1-1991.

In the four tank cases, the detectors were located on the centers of the domes, midway to the edge, above the inner wall, at the upper edge of the excavation, and at distances of $50 \mathrm{ft}$ and $100 \mathrm{ft}$ from the edge of the excavation. In addition, detectors were placed on perpendicular lines between the tanks. Both north-south and east-west lines were used. In all cases, the detectors were located $3 \mathrm{ft}$ above whatever surface was there, or in the case of missing domes, whatever surface used to be there.

In the single tank cases, dose rate tallies were obtained at the center, midway to the edge, at the inner edge, at the bottom of the excavation, at the top of the excavation, and at distances of $50 \mathrm{ft}$, $100 \mathrm{ft}, 150 \mathrm{ft}, 200 \mathrm{ft}, 300 \mathrm{ft}$, and 400 feet from the upper edge of the excavation. 


\subsection{MCNP - DOSE RATE RESULTS}

At present, the ambient background radiation in the 241-AX Tank Farm is about $0.05 \mathrm{mrem} / \mathrm{h}$. As the soil over the tank domes is removed, this will increase.

Dose rates from MCNP for the 99 percent retrieval case are shown in Tables 7 and 8 . Table 7 contains the dose rates from individual tanks at each of the detector locations. The last column shows the total from all four tanks combined. The relative errors reported by MCNP were generally less than 20 percent. Appendix $\mathrm{C}$ gives summary tables showing the relative errors reported by MCNP as well as the dose rates shown in Tables 7 and 8.

In Table 7, the first column of numbers gives the dose rates at the various dose points from just the residual activity in Tank AX-101. The dose rate directly over the AX-101 dome is $8.45 \mathrm{mrem} / \mathrm{h}$. The dose rate over the $\mathrm{AX}-102$ dome from the $\mathrm{AX}-101$ source is $0.03 \mathrm{mrem} / \mathrm{h}$. Therefore, dose accumulates during excavation only while the individuals are on top of a dome. The last column of Table 7 gives the dose rates after all four tanks have been uncovered.

Table 8 contains the dose rates after the first dome has been removed. The first column of numbers shows dose rates if the AX-101 dome is removed first. The second column of numbers shows the dose rates if AX-102's dome is removed first. The domes on the other tanks are still in place. Note that the numbers in Table 8 include the dose rates from the residual activity in each tank.

Dose rates from MCNP for 99.9 percent retrieval case are shown in Tables 9 and 10. The values shown on these tables are one-tenth the values shown on Tables 7 and 8 , since the source strength has been reduced by a factor of 10 .

The effect of grout shielding can be seen in the dose rates shown on Tables 11 and 12 . These dose rates use the single tank geometry with the 99 percent retrieval source strengths. Actual MCNP dose rates and relative errors are shown in Appendix C. The main conclusion is that the $70 \mathrm{lb} / \mathrm{ft}^{2}$ shield reduces the dose rates by about a factor of 10 at all detector locations. In addition, the $140 \mathrm{lb} / \mathrm{ft}^{2}$ reduces dose rates by a factor of 100 , and the $210 \mathrm{lb} / \mathrm{ft}^{2}$ reduces dose rates by a factor of 1000 . Another way of stating this is that every $50 \mathrm{lb} / \mathrm{ft}^{2}$ reduces the dose rates by a factor of 5 , and every $70 \mathrm{lb} / \mathrm{ft}^{2}$ reduces dose rates by a factor of 10 . Thus, a factor of $500 \mathrm{can}$ be achieved with $190 \mathrm{lb} / \mathrm{ft}^{2}$ of grout spread over the residual waste. 
HNF-3378-Rev. 0

Table 7. Dose Rates (mrem/h) After Excavation -- 99 Percent Retrieval

\begin{tabular}{|c|c|c|c|c|c|}
\hline Detector Location & $A X-101$ & AX-102 & $\mathrm{AX}-103$ & AX-104 & Total \\
\hline $\begin{array}{l}\text { Center of the Dome } \\
\text { AX-101 } \\
\text { AX-102 } \\
\text { AX-103 } \\
\text { AX-104 }\end{array}$ & $\begin{array}{l}8.45 \\
0.03 \\
0.04 \\
0.02\end{array}$ & $\begin{array}{c}0.19 \\
62.42 \\
0.11 \\
0.23\end{array}$ & $\begin{array}{r}0.34 \\
0.16 \\
95.83 \\
0.26\end{array}$ & $\begin{array}{r}0.16 \\
0.33 \\
0.25 \\
99.28\end{array}$ & $\begin{array}{r}9.13 \\
62.93 \\
96.23 \\
99.79\end{array}$ \\
\hline $\begin{array}{l}\text { Midway to Inner Edge } \\
\text { AX-101 north } \\
\text { AX-102 south } \\
\text { AX-103 north } \\
\text { AX-104 south }\end{array}$ & $\begin{array}{l}6.72 \\
0.02 \\
0.03 \\
0.01\end{array}$ & $\begin{array}{c}0.14 \\
44.24 \\
0.09 \\
0.20\end{array}$ & $\begin{array}{c}0.31 \\
0.14 \\
61.30 \\
0.19\end{array}$ & $\begin{array}{c}0.13 \\
0.30 \\
0.18 \\
69.70\end{array}$ & $\begin{array}{r}7.29 \\
44.70 \\
61.60 \\
70.11\end{array}$ \\
\hline $\begin{array}{l}\text { Inner Edge of the Dome } \\
\text { AX-101 east } \\
\text { AX-102 east } \\
\text { AX-103 west } \\
\text { AX-104 west }\end{array}$ & $\begin{array}{l}0.10 \\
0.02 \\
0.01 \\
0.01\end{array}$ & $\begin{array}{l}0.15 \\
0.72 \\
0.06 \\
0.09\end{array}$ & $\begin{array}{l}0.11 \\
0.09 \\
1.12 \\
0.19\end{array}$ & $\begin{array}{l}0.09 \\
0.11 \\
0.18 \\
1.54\end{array}$ & $\begin{array}{l}0.45 \\
0.94 \\
1.37 \\
1.82\end{array}$ \\
\hline $\begin{array}{l}\text { North-South Between Tanks } \\
100 \mathrm{ft} N \text { of Excavation } \\
50 \mathrm{ft} N \text { of Excavation } \\
\text { N Edge of Excavation } \\
\text { Between AX-101 \& AX-103 } \\
\text { Center Point } \\
\text { Between AX-102 \& AX-104 } \\
S \text { Edge of Excavation } \\
50 \mathrm{ft} S \text { of Excavation } \\
100 \mathrm{ft} S \text { of Excavation }\end{array}$ & $\begin{array}{l}0.01 \\
0.02 \\
0.05 \\
0.07 \\
0.04 \\
0.02 \\
0.01 \\
0.01 \\
0.00\end{array}$ & $\begin{array}{l}0.03 \\
0.04 \\
0.08 \\
0.14 \\
0.29 \\
0.46 \\
0.33 \\
0.10 \\
0.06\end{array}$ & $\begin{array}{l}0.09 \\
0.13 \\
0.45 \\
0.65 \\
0.36 \\
0.18 \\
0.12 \\
0.09 \\
0.04\end{array}$ & $\begin{array}{l}0.04 \\
0.07 \\
0.10 \\
0.19 \\
0.37 \\
0.64 \\
0.49 \\
0.14 \\
0.09\end{array}$ & $\begin{array}{l}0.16 \\
0.26 \\
0.67 \\
1.04 \\
1.06 \\
1.30 \\
0.95 \\
0.34 \\
0.19\end{array}$ \\
\hline $\begin{array}{l}\text { East-West Between Tanks } \\
100 \mathrm{ft} \text { E of Excavation } \\
50 \mathrm{ft} E \text { of Excavation } \\
\text { E Edge of Excavation } \\
\text { Between AX-101 \& AX-102 } \\
\text { Between AX-103 \& AX-104 } \\
\text { W Edge of Excavation } \\
50 \mathrm{ft} W \text { of Excavation } \\
100 \mathrm{ft} W \text { of Excavation }\end{array}$ & $\begin{array}{l}0.01 \\
0.01 \\
0.05 \\
0.05 \\
0.02 \\
0.01 \\
0.01 \\
0.00\end{array}$ & $\begin{array}{l}0.06 \\
0.10 \\
0.30 \\
0.39 \\
0.16 \\
0.09 \\
0.05 \\
0.03\end{array}$ & $\begin{array}{l}0.04 \\
0.08 \\
0.12 \\
0.20 \\
0.56 \\
0.43 \\
0.13 \\
0.09\end{array}$ & $\begin{array}{l}0.04 \\
0.08 \\
0.13 \\
0.19 \\
0.52 \\
0.45 \\
0.13 \\
0.08\end{array}$ & $\begin{array}{l}0.15 \\
0.28 \\
0.59 \\
0.84 \\
1.27 \\
0.98 \\
0.32 \\
0.20\end{array}$ \\
\hline $\begin{array}{l}\text { Points Near Excavation } \\
\text { NE Corner } \\
\text { AX-101 east } \\
\text { AX-102 east } \\
\text { SE Comer } \\
\text { NW Corner } \\
\text { AX-103 west } \\
\text { AX-104 west } \\
\text { SW Corner }\end{array}$ & $\begin{array}{l}0.03 \\
0.07 \\
0.02 \\
0.01 \\
0.01 \\
0.02 \\
0.01 \\
0.01\end{array}$ & $\begin{array}{l}0.08 \\
0.16 \\
0.47 \\
0.21 \\
0.04 \\
0.07 \\
0.09 \\
0.08\end{array}$ & $\begin{array}{l}0.10 \\
0.12 \\
0.12 \\
0.06 \\
0.32 \\
0.73 \\
0.21 \\
0.09\end{array}$ & $\begin{array}{l}0.07 \\
0.09 \\
0.12 \\
0.10 \\
0.09 \\
0.20 \\
0.72 \\
0.30\end{array}$ & $\begin{array}{l}0.29 \\
0.44 \\
0.74 \\
0.39 \\
0.47 \\
1.02 \\
1.03 \\
0.47\end{array}$ \\
\hline
\end{tabular}


HNF-3378-Rev. 0

Table 8. Total Dose Rates (mrem/h) with a Tank Dome Removed ( 99 percent)

\begin{tabular}{|c|c|c|c|c|}
\hline Detector Location & $\mathrm{AX}-101$ & $A X-102$ & $A X-103$ & AX-104 \\
\hline $\begin{array}{l}\text { Center of the Dome } \\
\text { AX-101 } \\
\text { AX-102 } \\
\text { AX-103 } \\
\text { AX-104 }\end{array}$ & $\begin{array}{c}1,944 \\
77 \\
114 \\
108\end{array}$ & $\begin{array}{c}111 \\
13,751 \\
159 \\
248\end{array}$ & $\begin{array}{c}245 \\
174 \\
20,660 \\
282\end{array}$ & $\begin{array}{c}124 \\
295 \\
274 \\
20,661\end{array}$ \\
\hline $\begin{array}{l}\text { Midway to Inner Edge } \\
\text { AX-101 north } \\
\text { AX-102 south } \\
\text { AX-103 north } \\
\text { AX-104 south }\end{array}$ & $\begin{array}{c}1,868 \\
54 \\
80 \\
77\end{array}$ & $\begin{array}{c}75 \\
13,300 \\
109 \\
193\end{array}$ & $\begin{array}{c}215 \\
136 \\
19,890 \\
195\end{array}$ & $\begin{array}{c}106 \\
264 \\
207 \\
19,610\end{array}$ \\
\hline $\begin{array}{l}\text { Inner Edge of the Dome } \\
\text { AX-101 east } \\
\text { AX-102 east } \\
\text { AX-103 west } \\
\text { AX-104 west }\end{array}$ & $\begin{array}{c}1,543 \\
11 \\
8 \\
7\end{array}$ & $\begin{array}{c}74 \\
11,140 \\
36 \\
53\end{array}$ & $\begin{array}{c}93 \\
68 \\
15,950 \\
141\end{array}$ & $\begin{array}{c}61 \\
85 \\
131 \\
16,020\end{array}$ \\
\hline $\begin{array}{l}\text { North-South Between Tanks } \\
100 \mathrm{ft} \text { of Excavation } \\
50 \mathrm{ft} \text { of Excavation } \\
\text { N Edge of Excavation } \\
\text { Between AX-101 \& AX-103 } \\
\text { Center Point } \\
\text { Between AX-102 \& AX-104 } \\
\text { S Edge of Excavation } \\
50 \mathrm{ft} S \text { of Excavation } \\
100 \mathrm{ft} S \text { of Excavation }\end{array}$ & $\begin{array}{c}5 \\
8 \\
25 \\
68 \\
23 \\
12 \\
7 \\
5 \\
2\end{array}$ & $\begin{array}{c}16 \\
26 \\
41 \\
73 \\
165 \\
476 \\
173 \\
60 \\
33\end{array}$ & $\begin{array}{c}60 \\
93 \\
293 \\
786 \\
311 \\
132 \\
81 \\
54 \\
26\end{array}$ & $\begin{array}{c}35 \\
45 \\
70 \\
134 \\
264 \\
832 \\
304 \\
102 \\
68\end{array}$ \\
\hline $\begin{array}{l}\text { East-West Between Tanks } \\
100 \mathrm{ft} \text { E of Excavation } \\
50 \mathrm{ft} E \text { of Excavation } \\
\text { E Edge of Excavation } \\
\text { Between AX-101 \& AX-102 } \\
\text { Between AX-103 \& AX-104 } \\
\text { W Edge of Excavation } \\
50 \mathrm{ft} W \text { of Excavation } \\
100 \mathrm{ft} W \text { of Excavation }\end{array}$ & $\begin{array}{c}5 \\
8 \\
24 \\
41 \\
12 \\
8 \\
4 \\
3\end{array}$ & $\begin{array}{c}44 \\
64 \\
182 \\
290 \\
86 \\
46 \\
28 \\
19\end{array}$ & $\begin{array}{c}34 \\
48 \\
80 \\
144 \\
520 \\
276 \\
93 \\
59\end{array}$ & $\begin{array}{c}30 \\
43 \\
83 \\
142 \\
508 \\
275 \\
103 \\
57\end{array}$ \\
\hline $\begin{array}{l}\text { Points Near Excavation } \\
\text { NE Corner } \\
\text { AX-101 east } \\
\text { AX-102 east } \\
\text { SE Corner } \\
\text { NW Corner } \\
\text { AX-103 west } \\
\text { AX-104 west } \\
\text { SW Corner }\end{array}$ & $\begin{array}{c}17 \\
35 \\
12 \\
5 \\
7 \\
8 \\
6 \\
4\end{array}$ & $\begin{array}{c}38 \\
81 \\
249 \\
119 \\
28 \\
38 \\
48 \\
40\end{array}$ & $\begin{array}{c}69 \\
88 \\
69 \\
39 \\
214 \\
430 \\
134 \\
63\end{array}$ & $\begin{array}{c}44 \\
65 \\
93 \\
67 \\
63 \\
143 \\
441 \\
193\end{array}$ \\
\hline
\end{tabular}


HNF-3378-Rev. 0

Table 9. Dose Rates (mrem/h) After Excavation -- 99.9 Percent Retrieval

\begin{tabular}{|c|c|c|c|c|c|}
\hline Detector Location & $A X-101$ & $A X-102$ & AX-103 & AX-104 & Total \\
\hline $\begin{array}{l}\text { Center of the Dome } \\
\text { AX-101 } \\
\text { AX-102 } \\
\text { AX-103 } \\
\text { AX-104 }\end{array}$ & $\begin{array}{l}0.85 \\
0.00 \\
0.00 \\
0.00\end{array}$ & $\begin{array}{l}0.02 \\
6.24 \\
0.01 \\
0.02\end{array}$ & $\begin{array}{l}0.03 \\
0.02 \\
9.58 \\
0.03\end{array}$ & $\begin{array}{l}0.02 \\
0.03 \\
0.03 \\
9.93\end{array}$ & $\begin{array}{l}0.91 \\
6.29 \\
9.62 \\
9.98\end{array}$ \\
\hline $\begin{array}{l}\text { Midway to Inner Edge } \\
\text { AX-101 north } \\
\text { AX-102 south } \\
\text { AX-103 north } \\
\text { AX-104 south }\end{array}$ & $\begin{array}{l}0.67 \\
0.00 \\
0.00 \\
0.00\end{array}$ & $\begin{array}{l}0.01 \\
4.42 \\
0.01 \\
0.02\end{array}$ & $\begin{array}{l}0.03 \\
0.01 \\
6.13 \\
0.02\end{array}$ & $\begin{array}{l}0.01 \\
0.03 \\
0.02 \\
6.97\end{array}$ & $\begin{array}{l}0.73 \\
4.47 \\
6.16 \\
7.01\end{array}$ \\
\hline $\begin{array}{l}\text { Inner Edge of the Dome } \\
\text { AX-101 east } \\
\text { AX-102 east } \\
\text { AX-103 west } \\
\text { AX-104 west }\end{array}$ & $\begin{array}{l}0.01 \\
0.00 \\
0.00 \\
0.00\end{array}$ & $\begin{array}{l}0.02 \\
0.07 \\
0.01 \\
0.01\end{array}$ & $\begin{array}{l}0.01 \\
0.01 \\
0.11 \\
0.02\end{array}$ & $\begin{array}{l}0.01 \\
0.01 \\
0.02 \\
0.15\end{array}$ & $\begin{array}{l}0.05 \\
0.09 \\
0.14 \\
0.18\end{array}$ \\
\hline $\begin{array}{l}\text { North-South Between Tanks } \\
100 \mathrm{ft} \text { of Excavation } \\
50 \mathrm{ft} \text { of Excavation } \\
\text { N Edge of Excavation } \\
\text { Between AX-101 \& AX-103 } \\
\text { Center Point } \\
\text { Between AX-102 \& AX-104 } \\
S \text { Edge of Excavation } \\
50 \mathrm{ft} S \text { of Excavation } \\
100 \mathrm{ft} S \text { of Excavation }\end{array}$ & $\begin{array}{l}0.00 \\
0.00 \\
0.00 \\
0.01 \\
0.00 \\
0.00 \\
0.00 \\
0.00 \\
0.00\end{array}$ & $\begin{array}{l}0.00 \\
0.00 \\
0.01 \\
0.01 \\
0.03 \\
0.05 \\
0.03 \\
0.01 \\
0.01\end{array}$ & $\begin{array}{l}0.01 \\
0.01 \\
0.04 \\
0.07 \\
0.04 \\
0.02 \\
0.01 \\
0.01 \\
0.00\end{array}$ & $\begin{array}{l}0.00 \\
0.01 \\
0.01 \\
0.02 \\
0.04 \\
0.06 \\
0.05 \\
0.01 \\
0.01\end{array}$ & $\begin{array}{l}0.02 \\
0.03 \\
0.07 \\
0.10 \\
0.11 \\
0.13 \\
0.09 \\
0.03 \\
0.02\end{array}$ \\
\hline $\begin{array}{l}\text { East-West Between Tanks } \\
100 \mathrm{ft} \text { E of Excavation } \\
50 \mathrm{ft} E \text { of Excavation } \\
\text { E Edge of Excavation } \\
\text { Between AX-101 \& AX-102 } \\
\text { Between AX-103 \& AX-104 } \\
W \text { Edge of Excavation } \\
50 \mathrm{ft} W \text { of Excavation } \\
100 \mathrm{ft} W \text { of Excavation }\end{array}$ & $\begin{array}{l}0.00 \\
0.00 \\
0.00 \\
0.01 \\
0.00 \\
0.00 \\
0.00 \\
0.00\end{array}$ & $\begin{array}{l}0.01 \\
0.01 \\
0.03 \\
0.04 \\
0.02 \\
0.01 \\
0.01 \\
0.00\end{array}$ & $\begin{array}{l}0.00 \\
0.01 \\
0.01 \\
0.02 \\
0.06 \\
0.04 \\
0.01 \\
0.01\end{array}$ & $\begin{array}{l}0.00 \\
0.01 \\
0.01 \\
0.02 \\
0.05 \\
0.04 \\
0.01 \\
0.01\end{array}$ & $\begin{array}{l}0.02 \\
0.03 \\
0.06 \\
0.08 \\
0.13 \\
0.10 \\
0.03 \\
0.02\end{array}$ \\
\hline $\begin{array}{l}\text { Points Near Excavation } \\
\text { NE Corner } \\
\text { AX-101 east } \\
\text { AX-102 east } \\
\text { SE Corner } \\
\text { NW Corner } \\
\text { AX-103 west } \\
\text { AX-104 west } \\
\text { SW Corner }\end{array}$ & $\begin{array}{l}0.00 \\
0.01 \\
0.00 \\
0.00 \\
0.00 \\
0.00 \\
0.00 \\
0.00\end{array}$ & $\begin{array}{l}0.01 \\
0.02 \\
0.05 \\
0.02 \\
0.00 \\
0.01 \\
0.01 \\
0.01\end{array}$ & $\begin{array}{l}0.01 \\
0.01 \\
0.01 \\
0.01 \\
0.03 \\
0.07 \\
0.02 \\
0.01\end{array}$ & $\begin{array}{l}0.01 \\
0.01 \\
0.01 \\
0.01 \\
0.01 \\
0.02 \\
0.07 \\
0.03\end{array}$ & $\begin{array}{l}0.03 \\
0.04 \\
0.07 \\
0.04 \\
0.05 \\
0.10 \\
0.10 \\
0.05\end{array}$ \\
\hline
\end{tabular}


HNF-3378-Rev. 0

Table 10. Total Dose Rates (mrem/h) with a Tank Dome Removed ( 99.9 Percent)

\begin{tabular}{|c|c|c|c|c|}
\hline Detector Location & $A X-101$ & $\mathrm{AX}-102$ & $A X-103$ & $\mathrm{AX}-104$ \\
\hline $\begin{array}{l}\text { Center of the Dome } \\
\text { AX-101 } \\
\text { AX-102 } \\
\text { AX-103 } \\
\text { AX-104 }\end{array}$ & $\begin{array}{c}194 \\
7.7 \\
11.4 \\
10.8\end{array}$ & $\begin{array}{l}11.1 \\
1375 \\
15.9 \\
24.8\end{array}$ & $\begin{array}{c}24.5 \\
17.4 \\
2066 \\
28.2\end{array}$ & $\begin{array}{c}12.4 \\
29.5 \\
27.4 \\
2066\end{array}$ \\
\hline $\begin{array}{l}\text { Midway to Inner Edge } \\
\text { AX-101 north } \\
\text { AX-102 south } \\
\text { AX-103 north } \\
\text { AX-104 south }\end{array}$ & $\begin{array}{l}187 \\
5.4 \\
8.0 \\
7.7\end{array}$ & $\begin{array}{c}7.5 \\
1330 \\
10.9 \\
19.3\end{array}$ & $\begin{array}{l}21.5 \\
13.6 \\
1989 \\
19.5\end{array}$ & $\begin{array}{c}10.6 \\
26.4 \\
20.7 \\
1961\end{array}$ \\
\hline $\begin{array}{l}\text { Inner Edge of the Dome } \\
\text { AX-101 east } \\
\text { AX-102 east } \\
\text { AX-103 west } \\
\text { AX-104 west }\end{array}$ & $\begin{array}{l}154 \\
1.1 \\
0.8 \\
0.7\end{array}$ & $\begin{array}{c}7.4 \\
1114 \\
3.6 \\
5.3\end{array}$ & $\begin{array}{c}9.3 \\
6.8 \\
1595 \\
14.1\end{array}$ & $\begin{array}{c}6.1 \\
8.5 \\
13.1 \\
1602\end{array}$ \\
\hline $\begin{array}{l}\text { North-South Between Tanks } \\
100 \mathrm{ft} N \text { of Excavation } \\
50 \mathrm{ft} N \text { of Excavation } \\
\text { N Edge of Excavation } \\
\text { Between AX-101 \& AX-103 } \\
\text { Center Point } \\
\text { Between AX-102 \& AX-104 } \\
\text { S Edge of Excavation } \\
50 \mathrm{ft} S \text { of Excavation } \\
100 \mathrm{ft} S \text { of Excavation }\end{array}$ & $\begin{array}{l}0.5 \\
0.8 \\
2.5 \\
6.8 \\
2.3 \\
1.2 \\
0.7 \\
0.5 \\
0.2\end{array}$ & $\begin{array}{c}1.6 \\
2.6 \\
4.1 \\
7.3 \\
16.5 \\
47.6 \\
17.3 \\
6.0 \\
3.3\end{array}$ & $\begin{array}{c}6.0 \\
9.3 \\
29.3 \\
78.6 \\
31.1 \\
13.2 \\
8.1 \\
5.4 \\
2.6\end{array}$ & $\begin{array}{c}3.5 \\
4.5 \\
7.0 \\
13.4 \\
26.4 \\
83.2 \\
30.4 \\
10.2 \\
6.8\end{array}$ \\
\hline $\begin{array}{l}\text { East-West Between Tanks } \\
100 \mathrm{ft} \text { E of Excavation } \\
50 \mathrm{ft} \text { E of Excavation } \\
\text { E Edge of Excavation } \\
\text { Between AX-101 \& AX-102 } \\
\text { Between AX-103 \& AX-104 } \\
W \text { Edge of Excavation } \\
50 \mathrm{ft} W \text { of Excavation } \\
100 \mathrm{ft} W \text { of Excavation }\end{array}$ & $\begin{array}{l}0.5 \\
0.8 \\
2.4 \\
4.1 \\
1.2 \\
0.8 \\
0.4 \\
0.3\end{array}$ & $\begin{array}{c}4.4 \\
6.4 \\
18.2 \\
29.0 \\
8.6 \\
4.6 \\
2.8 \\
1.9\end{array}$ & $\begin{array}{c}3.4 \\
4.8 \\
8.0 \\
14.4 \\
52.0 \\
27.6 \\
9.3 \\
5.9\end{array}$ & $\begin{array}{c}3.0 \\
4.3 \\
8.3 \\
14.2 \\
50.8 \\
27.5 \\
10.3 \\
5.7\end{array}$ \\
\hline $\begin{array}{l}\text { Points Near Excavation } \\
\text { NE Comer } \\
\text { AX-101 east } \\
\text { AX-102 east } \\
\text { SE Corner } \\
\text { NW Corner } \\
\text { AX-103 west } \\
\text { AX-104 west } \\
\text { SW Comer }\end{array}$ & $\begin{array}{l}1.7 \\
3.5 \\
1.2 \\
0.5 \\
0.7 \\
0.8 \\
0.6 \\
0.4\end{array}$ & $\begin{array}{c}3.8 \\
8.1 \\
24.9 \\
11.9 \\
2.8 \\
3.8 \\
4.8 \\
4.0\end{array}$ & $\begin{array}{c}6.9 \\
8.8 \\
6.9 \\
3.9 \\
21.4 \\
43.0 \\
13.4 \\
6.3\end{array}$ & $\begin{array}{c}4.4 \\
6.5 \\
9.3 \\
6.7 \\
6.3 \\
14.3 \\
44.1 \\
19.3\end{array}$ \\
\hline
\end{tabular}


HNF-3378-Rev. 0

Table 11. Single Tank Dose Rates (mrem/h) After Excavation

\begin{tabular}{|c|c|c|c|c|}
\hline Detector Location & No Shield & $70 \mathrm{lb} / \mathrm{ft}^{2}$ & $141 \mathrm{lb} / \mathrm{ft}^{2}$ & $211 \mathrm{lb} / \mathrm{ft}^{2}$ \\
\hline \multicolumn{5}{|l|}{ AX-101 Source } \\
\hline $3 \mathrm{ft}$ Below Dome & $2.9 \mathrm{E}+03$ & $3.7 E+02$ & $3.6 \mathrm{E}+01$ & $3.2 \mathrm{E}+00$ \\
\hline Center of Tank & $8.7 \mathrm{E}+00$ & $9.5 \mathrm{E}-01$ & $1.1 \mathrm{E}-01$ & $6.1 \mathrm{E}-03$ \\
\hline Midway to Edge & $6.8 \mathrm{E}+00$ & $6.7 \mathrm{E}-01$ & $6.0 \mathrm{E}-02$ & $5.7 \mathrm{E}-03$ \\
\hline Inner Edge of Tank & $1.1 \mathrm{E}-01$ & $1.1 \mathrm{E}-02$ & $8.7 \mathrm{E}-04$ & $9.7 \mathrm{E}-05$ \\
\hline Bottom Edge of Excavation & $5.8 \mathrm{E}-02$ & $5.7 \mathrm{E}-03$ & $5.7 \mathrm{E}-04$ & $4.9 \mathrm{E}-05$ \\
\hline Upper Edge of Excavation & $7.2 \mathrm{E}-02$ & $7.6 \mathrm{E}-03$ & $6.4 \mathrm{E}-04$ & $5.7 \mathrm{E}-05$ \\
\hline $50 \mathrm{ft}$ from Excavation & $1.7 \mathrm{E}-02$ & $1.8 \mathrm{E}-03$ & $1.6 \mathrm{E}-04$ & $1.3 \mathrm{E}-05$ \\
\hline $100 \mathrm{ft}$ from Excavation & $1.0 \mathrm{E}-02$ & $9.5 \mathrm{E}-04$ & $1.2 \mathrm{E}-04$ & $8.8 \mathrm{E}-06$ \\
\hline $150 \mathrm{ft}$ from Excavation & $6.4 \mathrm{E}-03$ & $6.5 \mathrm{E}-04$ & $6.1 \mathrm{E}-05$ & $5.9 \mathrm{E}-06$ \\
\hline $200 \mathrm{ft}$ from Excavation & 4.7E-03 & $4.3 \mathrm{E}-04$ & $4.2 \mathrm{E}-05$ & $4.2 \mathrm{E}-06$ \\
\hline $300 \mathrm{ft}$ from Excavation & $2.5 \mathrm{E}-03$ & $2.0 \mathrm{E}-04$ & $2.2 \mathrm{E}-05$ & $1.6 \mathrm{E}-06$ \\
\hline $400 \mathrm{ft}$ from Excavation & $1.5 \mathrm{E}-03$ & $1.3 \mathrm{E}-04$ & $2.6 \mathrm{E}-05$ & $9.8 \mathrm{E}-07$ \\
\hline \multicolumn{5}{|l|}{ AX-102 Source } \\
\hline $3 \mathrm{ft}$ Below Dome & $2.1 \mathrm{E}+04$ & $2.6 \mathrm{E}+03$ & $2.4 \mathrm{E}+02$ & $2.2 \mathrm{E}+01$ \\
\hline Center of Tank & $5.8 \mathrm{E}+01$ & $5.5 \mathrm{E}+00$ & $6.8 \mathrm{E}-01$ & $6.1 \mathrm{E}-02$ \\
\hline Midway to Edge & $4.3 \mathrm{E}+01$ & $4.6 \mathrm{E} \div 00$ & $5.0 \mathrm{E}-01$ & $2.8 \mathrm{E}-02$ \\
\hline Inner Edge of Tank & $7.1 \mathrm{E}-01$ & $6.7 \mathrm{E}-02$ & $5.5 \mathrm{E}-03$ & $4.9 \mathrm{E}-04$ \\
\hline Bottom Edge of Excavation & $3.9 \mathrm{E}-01$ & $3.7 \mathrm{E}-02$ & $3.4 \mathrm{E}-03$ & 2.7E-04 \\
\hline Upper Edge of Excavation & 4.9E-01 & $5.1 \mathrm{E}-02$ & 4.1E-03 & $3.8 \mathrm{E}-04$ \\
\hline $50 \mathrm{ft}$ from Excavation & $1.2 \mathrm{E}-01$ & $1.2 \mathrm{E}-02$ & $1.0 \mathrm{E}-03$ & $9.0 \mathrm{E}-05$ \\
\hline $100 \mathrm{ft}$ from Excavation & $7.6 \mathrm{E}-02$ & $6.4 \mathrm{E}-03$ & $5.5 \mathrm{E}-04$ & $5.9 E-05$ \\
\hline $150 \mathrm{ft}$ from Excavation & $4.4 \mathrm{E}-02$ & $4.1 \mathrm{E}-03$ & 4.9E-04 & $3.7 \mathrm{E}-05$ \\
\hline $200 \mathrm{ft}$ from Excavation & $3.1 \mathrm{E}-02$ & $2.8 \mathrm{E}-03$ & $2.3 \mathrm{E}-04$ & $2.5 \mathrm{E}-05$ \\
\hline $300 \mathrm{ft}$ from Excavation & $1.6 \mathrm{E}-02$ & $1.5 \mathrm{E}-03$ & 1.7E-04 & 2.3E-05 \\
\hline $400 \mathrm{ft}$ from Excavation & $9.2 \mathrm{E}-03$ & $8.8 \mathrm{E}-04$ & $7.3 \mathrm{E}-05$ & 8.1E-06 \\
\hline \multicolumn{5}{|l|}{ AX-103/104 Source } \\
\hline $3 \mathrm{ft}$ Below Dome & $3.1 \mathrm{E}+04$ & $3.3 \mathrm{E}+03$ & $3.3 \mathrm{E}+02$ & $3.4 \mathrm{E}+01$ \\
\hline Center of Tank & $8.3 \mathrm{E}+01$ & $1.1 \mathrm{E}+01$ & $1.7 E+00$ & $2.0 \mathrm{E}-01$ \\
\hline Midway to Edge & $6.3 \mathrm{E}+01$ & $6.4 \mathrm{E}+00$ & $9.9 \mathrm{E}-01$ & $1.0 \mathrm{E}-01$ \\
\hline Inner Edge of Tank & $1.1 \mathrm{E}+00$ & $9.2 \mathrm{E}-02$ & $1.3 \mathrm{E}-02$ & $1.5 \mathrm{E}-03$ \\
\hline Bottom Edge of Excavation & $5.2 \mathrm{E}-01$ & $5.1 \mathrm{E}-02$ & $6.8 \mathrm{E}-03$ & $7.8 \mathrm{E}-04$ \\
\hline Upper Edge of Excavation & 7.3E-01 & $8.3 \mathrm{E}-02$ & $9.8 \mathrm{E}-03$ & 1. $1 \mathrm{E}-03$ \\
\hline $50 \mathrm{ft}$ from Excavation & $1.5 \mathrm{E}-01$ & $1.5 \mathrm{E}-02$ & 2.1E-03 & $2.3 \mathrm{E}-04$ \\
\hline $100 \mathrm{ft}$ from Excavation & $9.6 \mathrm{E}-02$ & $1.4 \mathrm{E}-02$ & 1.3E-03 & $1.2 \mathrm{E}-04$ \\
\hline $150 \mathrm{ft}$ from Excavation & $6.8 \mathrm{E}-02$ & $6.8 \mathrm{E}-03$ & $7.4 \mathrm{E}-04$ & $8.2 \mathrm{E}-05$ \\
\hline $200 \mathrm{ft}$ from Excavation & $4.2 \mathrm{E}-02$ & $4.1 E-03$ & $4.5 \mathrm{E}-04$ & $5.1 \mathrm{E}-05$ \\
\hline $300 \mathrm{ft}$ from Excavation & $2.3 E-02$ & $2.8 \mathrm{E}-03$ & 2.2E-04 & $5.4 \mathrm{E}-05$ \\
\hline $400 \mathrm{ft}$ from Excavation & $1.2 \mathrm{E}-02$ & $1.2 \mathrm{E}-03$ & 1.3E-04 & $2.0 \mathrm{E}-05$ \\
\hline
\end{tabular}


HNF-3378-Rev. 0

Table 12. Single Tank Dose Rates (mrem/h) With Dome Removed

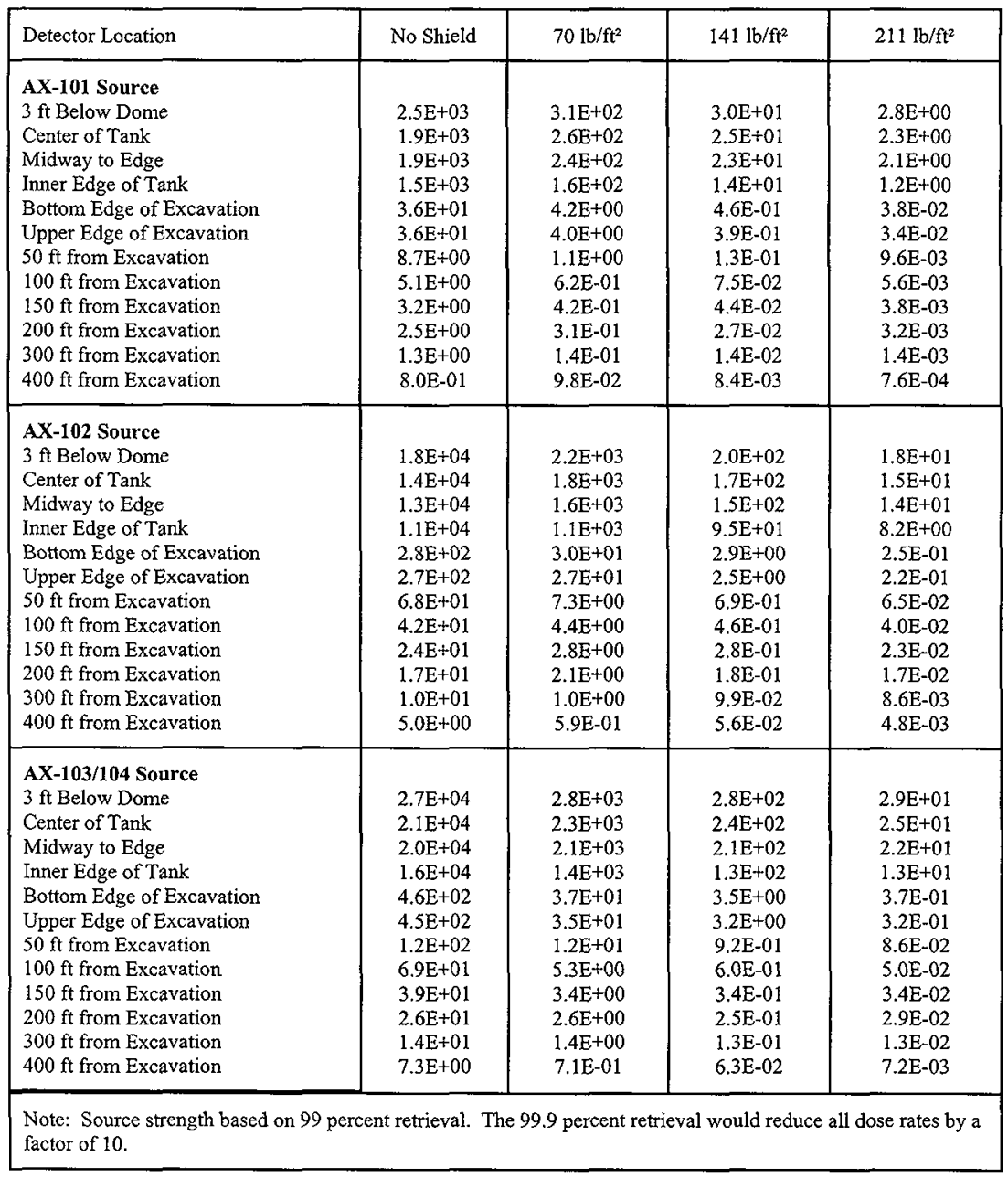




\subsection{ISO-PC -- DEBRIS EXCAVATION}

It is assumed that the tank dome can be removed with the waste well shielded by a layer of grout. The debris from demolition of the tank dome and walls adds to this shielding. However, when the debris is lifted into waste containers for shipment to its final resting location, some of the activity is again uncovered. This is particularly true during sectioning of the sheet steel on the floor of the tank. Most of the activity is assumed to adhere to this steel.

The ISO-PC model assumes that $4 \mathrm{~m}^{2}$ of tank floor are exposed at a time. This was represented as a circular area $7^{\prime} 5^{\prime \prime}(225.68 \mathrm{~cm})$ in diameter. The source strength was the full tank inventory multiplied by 0.00115 , which is $4 \mathrm{~m}^{2}$ divided by the total source area, $347 \mathrm{~m}^{2}$.

The source thickness was assumed to be 3 in. $(7.62 \mathrm{~cm})$. Since the steel liner on the bottom of the tank is being lifted, it was assumed to be a shield between the residual activity and the operator. The thickness of this steel is $3 / 8$ in. $(0.953 \mathrm{~cm})$.

The source composition in ISO-PC approximates that shown on Table 4. Some of the elements are not available in the ISO-PC shield material library. Since the source region is only 3 in. thick, and composed of moderate density, low atomic number material, the assumptions made about its composition have little effect on the final dose rates.

Input files for the ISO-PC software are listed in Appendix D.

Computed dose rates for the $4 \mathrm{~m}^{2}$ source are shown in Table 13. These are based on the 99 percent retrieval assumption. The excavator operator will be positioned about $15 \mathrm{ft}$ from the waste when handling the nearest sections. This distance will increase to at most $50 \mathrm{ft}$ or $60 \mathrm{ft}$, based on the length of the shovel arm.

Since the dose rates are greater than $100 \mathrm{mrem} / \mathrm{h}$, various thicknesses of iron were also applied to the source, representing shielding on the outside of the excavator. The shielded dose rates are also shown on Table 13. About 2 in. of iron will reduce the dose rates by a factor of 10 . Thus, $4 \mathrm{in}$. of iron is needed to obtain moderate dose rates at distances of $15 \mathrm{ft}$ to $20 \mathrm{ft}$, where the operator is located during some of the removal excavation.

For the 99.9 percent retrieval case, the source is 10 times smaller. Thus the dose rates are 10 times smaller, and the iron thickness can be reduced by 2 inches. 
HNF-3378-Rev. 0

Table 13. Dose Rates (mrem/h) During Debris Removal

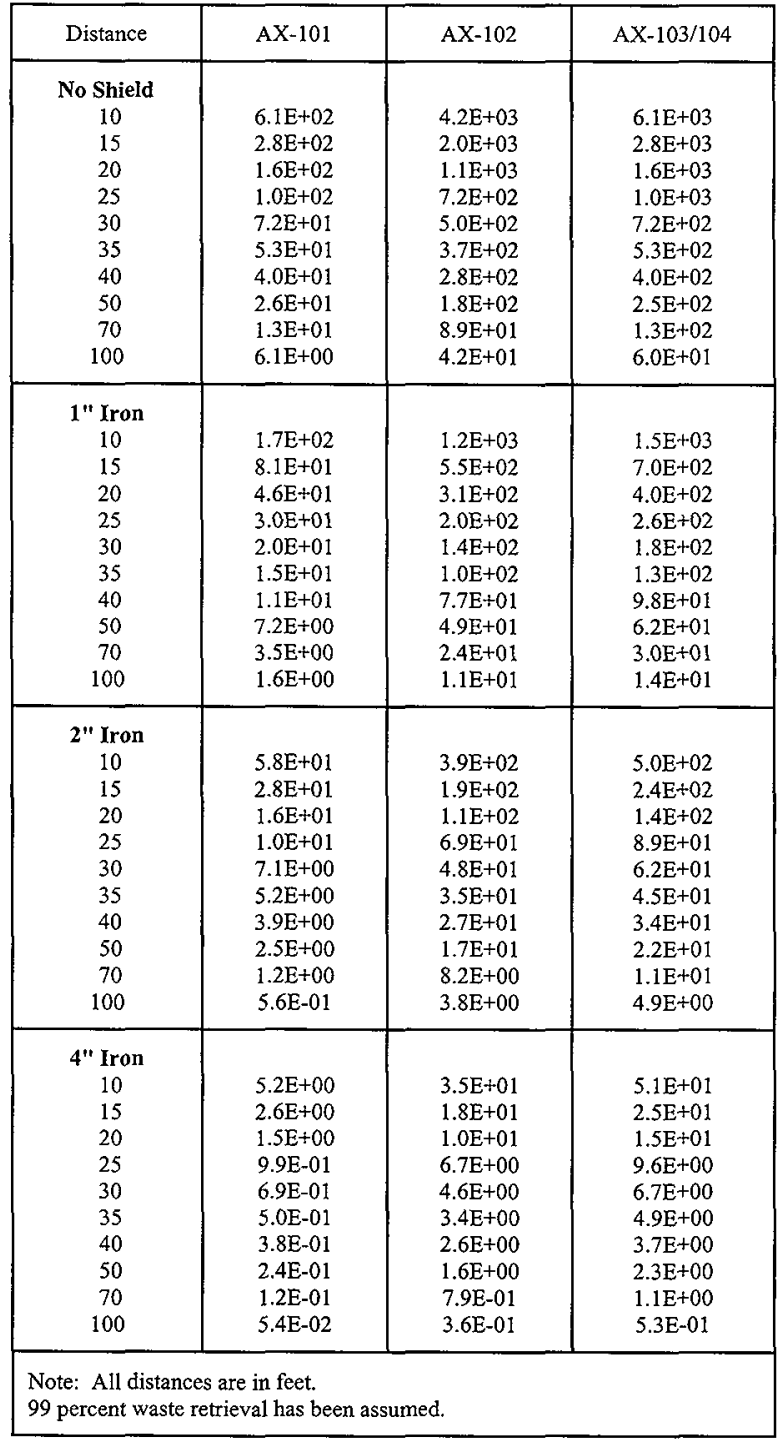




\subsection{ISO-PC -- SHIPPING CONTAINER DESIGN}

After demolition of the dome and walls of the tank, the rubble will have a density of about $102 \mathrm{lbs} / \mathrm{ft}^{3}$. The average Cs-137 activity concentration in this rubble for Tanks AX-103 and AX-104 is about 0.5 curies per cubic foot. These features of the rubble were used to determine the dose rates near various iron-walled boxes representing shipping containers. Additional constraints on the box was a gross weight of $38,000 \mathrm{lbs}$, and relative dimensions for the height, width, and length of 1 to 1.2 to 4 .

Table 14. Comparison of Shipping Boxes

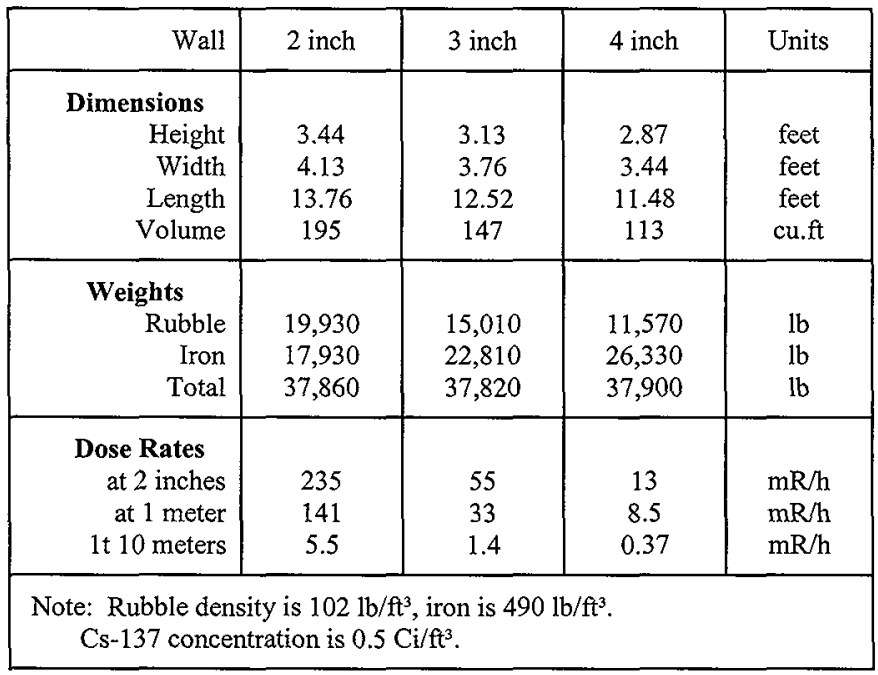

Due to the size of the container, the $200 \mathrm{mR} / \mathrm{h}$ dose rate limit on the outside of the container is not limiting. Rather, the dose rate at 1 meter from the side of the container is. In order to lower dose rates below the limit of $10 \mathrm{mR} / \mathrm{h}$, the box will need to have 4 in. thick walls.

Dose rates were computed using the ISO-PC software. The input file is listed in Appendix D for reference.

\subsection{DOSE RATE ESTIMATES FOR THE POSTULATED 241-AX TANK LEAKS}

After removal of the tank floor, any contaminated soil would also need to be excavated and disposed of. This section calculates estimates for worker dose rates during excavation. Two leakage assumptions were evaluated: $30,283 \mathrm{~L}(8,000 \mathrm{gal})$ and $151,413 \mathrm{~L}(40,000 \mathrm{gal})$. 
The volume of soil contaminated is assumed to have a semi-ellipsoid shape, where the flat surface is at the soil-air interface. The major axis of the ellipsoid is assumed to be vertical, and roughly 1.5 times the minor axis for the 8,000 gal leak. For the 40,000 gal leak the major axis is assumed to be twice the minor axis. This reflects the greater vertical movement of the larger leak.

Actual soil volumes contaminated were estimated by assuming the soil moisture would have increased about 0.75 percent. This increase is assumed to be the case after a significant period of time from when the leak occurred. The dimensions of the contaminated soil are shown in the table below.

\begin{tabular}{|c|c|c|}
\hline \multicolumn{3}{|c|}{ Dimensions of the Contaminated Soil } \\
\hline & 8,000 gallon leak & 40,000 gallon leak \\
\hline Leak Volume & $\begin{array}{c}30,283 \mathrm{~L} \\
\left(1,069 \mathrm{ft}^{3}\right)\end{array}$ & $\begin{array}{l}151,416 \mathrm{~L} \\
\left(5,347 \mathrm{ft}^{3}\right)\end{array}$ \\
\hline Soil Volume & $\begin{array}{c}4,038 \mathrm{~m}^{3} \\
\left(142,593 \mathrm{ft}^{3}\right)\end{array}$ & $\begin{array}{c}20,189 \mathrm{~m}^{3} \\
\left(712,963 \mathrm{ft}^{3}\right)\end{array}$ \\
\hline $\begin{array}{l}\text { Semi-Minor Axis } \\
\text { (surface radius) }\end{array}$ & $\begin{array}{l}10.87 \mathrm{~m} \\
(35.7 \mathrm{ft})\end{array}$ & $\begin{array}{l}16.89 \mathrm{~m} \\
(55.4 \mathrm{ft})\end{array}$ \\
\hline $\begin{array}{l}\text { Semi-Major Axis } \\
\text { (soil depth) }\end{array}$ & $\begin{array}{l}16.31 \mathrm{~m} \\
(53.5 \mathrm{ft})\end{array}$ & $\begin{array}{c}33.78 \mathrm{~m} \\
(110.8 \mathrm{ft})\end{array}$ \\
\hline \multicolumn{3}{|c|}{$\begin{array}{l}\text { Note: The leaked solution is assumed to increase the soil moisture by } 0.75 \\
\text { percent. The contaminated soil volume is computed as follows: } \\
\qquad V_{\text {soil }}=V_{\text {teak }} / 0.0075=2 \pi / 3 \mathrm{La}^{2} \mathrm{Lb} \\
\text { where, } \\
\mathrm{V}_{\text {soil }}=\text { Leak Volume } \\
\mathrm{V}_{\text {leak }}=\text { Soil Volume } \\
\mathrm{La}=\text { semi-minor axis (radius at the surface) } \\
\mathrm{Lb}=\text { semi-major axis (greatest depth of contamination) }\end{array}$} \\
\hline
\end{tabular}

The two main radionuclides in the soil, $\mathrm{Cs}-137$ and $\mathrm{Sr}-90$, are both adsorbed onto soil particles. Thus the radionuclide concentration will not be uniform throughout the contaminated soil volume. From well data presented in the "AX Tank Farm Preliminary Report" (GJO-97-7-TAR/GJO-HAN-10, April 1997), the Cs-137 concentration decreases a factor of 10 in about $20 \mathrm{ft}$. (See Appendix A, graph 11-03-02.) It was assumed for simplicity that the exponential decrease in soil concentration only applies to the vertical dimension. Horizontally the soil concentration does not change. The equation below shows the spatial dependence of the nuclide concentration inside the contaminated soil volume.

where,

$$
C=\operatorname{Co} \operatorname{Exp}(-\mathrm{a} Z)
$$

$\mathrm{C}=$ soil concentration at some location inside the semi-ellipsoid,

$\mathrm{Co}=$ soil concentration at the center of the full ellipsoid, i.e., at the soil-air interface

$\mathrm{a}=$ exponential slope, assumed to be 0.3777 per $\mathrm{m}(0.1151$ per $\mathrm{ft})$. 
$Z=$ depth below the surface (increases downward)

The initial soil concentration can be found by requiring that the volume integral of the concentration in the semi-ellipsoid equal the total activity leaked. The formula for this integral is shown below.

$$
A_{\text {total }}=\frac{2 \Pi L_{a}^{2} C_{0} \rho}{a}\left[\frac{1}{2}-\frac{1}{\left(a L_{b}\right)^{2}}+\frac{\operatorname{Exp}\left(-a L_{b}\right)}{a L_{b}}\left(1+\frac{1}{a L_{b}}\right)\right]
$$

The density term ( $\varrho$ ) is the soil density, which is assumed to be $2.24 \mathrm{~g} / \mathrm{cc}\left(140 \mathrm{lb} / \mathrm{ft}^{3}\right)$. This high value represents the compacted nature of the soil under the tanks. Notice that the only unknown variable in this equation is the surface soil concentration $(\mathrm{Co})$. The total activity postulated to leak has been estimated by others and sent to me via electronic mail. The totals assumed in these calculations are shown in the table below.

\begin{tabular}{|c|c|c|c|c|}
\hline \multicolumn{5}{|c|}{ Total Activity (Curies) from Postulated Leaks (99\% Retrieval) } \\
\hline \multirow{2}{*}{$\mathrm{A}_{\text {total }}$} & 8,000 Gallon Leak & 40,000 Gallon Leak \\
\cline { 2 - 5 } & Sr-90 & Cs-137 & Sr-90 & Cs-137 \\
\hline AX-101 & 4,473 & 2,364 & 22,363 & 11,820 \\
\hline AX-102 & 11,133 & 4,731 & 55,667 & 23,654 \\
\hline AX-103 & 95,354 & 4,161 & 476,772 & 20,805 \\
\hline AX-104 & 130,938 & 2,716 & 654,692 & 13,581 \\
\hline $\begin{array}{l}\text { Note: All values have been aged to 12/31/99. Y-90 and Ba-137m are not shown on } \\
\text { the table, but are present in equilibrium amounts. The dose calculations include these } \\
\text { equilibrium amounts. }\end{array}$ \\
\hline
\end{tabular}

The concentration to total conversion factor (what is multiplied by Co in the above equation) turns out to be $2.091 \mathrm{Ci}$ per $\mathrm{nCi} / \mathrm{g}$ for the 8,000 gal leak and $5.259 \mathrm{Ci}$ per $\mathrm{nCi} / \mathrm{g}$ for the $40,000 \mathrm{gal}$ leak. Thus the surface soil concentrations can be calculated by dividing the total activity discharged by the conversion factor. These concentrations are listed in the table below.

\begin{tabular}{|c|c|c|c|c|}
\hline \multicolumn{5}{|c|}{ Surface Soil Concentrations (nCi/g) from Postulated Leaks } \\
\hline & 8,000 Gallon Leak & 40,000 Gallon Leak \\
\cline { 2 - 5 } & Sr-90 & Cs-137 & Sr-90 & Cs-137 \\
\hline $\mathrm{AX}-101$ & 2,139 & 1,130 & 4,252 & 2,248 \\
\hline $\mathrm{AX}-102$ & 5,323 & 2,262 & 10,585 & 4,498 \\
\hline $\mathrm{AX}-103$ & 45,594 & 1,990 & 90,658 & 3,956 \\
\hline $\mathrm{AX}-104$ & 62,608 & 1,299 & 124,489 & 2,582 \\
\hline
\end{tabular}


To examine the variation of activity with depth, the integral can be solved in more detail. The activity in the layer between $\mathrm{Za}$ and $\mathrm{Zb}$ is shown below.

$$
\begin{aligned}
& A_{\text {layer }}=\frac{\Pi L_{a}^{2} C_{0} \rho}{\left(a L_{b}\right)^{2}}\left[F\left(Z_{a}\right)-F\left(Z_{b}\right)\right] \\
& F(Z)=\operatorname{Exp}(-a Z)\left[a\left(L_{b}^{2}-Z^{2}\right)-2\left(\frac{1}{a}+Z\right)\right]
\end{aligned}
$$

The volume of soil in this same layer is shown below:

$$
C_{\text {layer }}^{\text {ave }}=\frac{3 C_{0}\left[F\left(Z_{b}\right)-F\left(Z_{a}\right)\right]}{a^{2}\left(Z_{b}-Z_{a}\right)\left[3 L_{b}^{2}-\left(Z_{a}^{2}+Z_{a} Z_{b}+Z_{b}^{2}\right)\right]}
$$

Thus the average concentration in a layer is given by:

$$
V_{\text {layer }}=\pi L_{a}^{2}\left(Z_{b}-Z_{a}\right)\left[1-\left(\frac{Z_{a}^{2}+Z_{a} Z_{b}}{3 L_{b}^{2}}\right.\right.
$$

The table below shows the average relative concentrations for both leak volumes. The averaging takes place over a 3 in. layer just below the depth shown in the first column. It is assumed that the surface concentration is 1.0 for this table.

\begin{tabular}{|c|c|}
\hline \multicolumn{2}{|c|}{ Relative Soil Concentrations in Various 3 inch Layers } \\
\hline Top of Layer, tt & Relative Concentration \\
\hline 0.00 & 0.9857 \\
0.25 & 0.9578 \\
0.50 & 0.9306 \\
0.75 & 0.9042 \\
1.00 & 0.8785 \\
1.25 & 0.8536 \\
1.50 & 0.8294 \\
1.75 & 0.8059 \\
\hline Note: Averages concentrations are shown. The relative \\
concentrations are the same for both leak volumes due to the thin \\
layers which are near the surface. \\
\hline
\end{tabular}


The ISO-PC program (Rittman 1995) was used to calculate dose rates from the soil layers with a concentration at the surface of $1 \mathrm{nCi} / \mathrm{g}$. The soil density is $2.24 \mathrm{~g} / \mathrm{cc}$. It was represented as Hanford soil in ISO-PC. The end-of-cylinder geometry was used. The cylinder radius is the semi-minor axis length. Dose rates were computed at a height of $1 \mathrm{~m}$ above the center of the cylinder. The input file for this case is shown in the first attachment. Dose results are shown in the table below. The fractional contribution to the dose rate from each layer is also shown. The high soil density means that contamination below a depth of $2 \mathrm{ft}$ contributes negligibly to the total dose rate.

\begin{tabular}{|c|c|c|c|c|}
\hline \multicolumn{5}{|c|}{ Comparison of Dose Rates from Various Depths } \\
\hline $\begin{array}{c}\text { Depth of } \\
\text { Top of Layer } \\
\text { (ft) }\end{array}$ & ISO-PC Results, mrem/h & Fraction from Each Layer \\
\cline { 2 - 5 } & Sr-90 & Cs-137 & Sr-90 & Cs-137 \\
\hline 0.00 & $7.19 \mathrm{E}-03$ & $4.52 \mathrm{E}-01$ & 84.60 & 77.12 \\
0.25 & $1.02 \mathrm{E}-03$ & $9.81 \mathrm{E}-02$ & 11.95 & 16.72 \\
0.50 & $2.17 \mathrm{E}-04$ & $2.61 \mathrm{E}-02$ & 2.55 & 4.44 \\
0.75 & $5.42 \mathrm{E}-05$ & $7.22 \mathrm{E}-03$ & 0.64 & 1.23 \\
1.00 & $1.51 \mathrm{E}-05$ & $2.04 \mathrm{E}-03$ & 0.18 & 0.35 \\
1.25 & $4.56 \mathrm{E}-06$ & $5.81 \mathrm{E}-04$ & 0.05 & 0.10 \\
1.50 & $1.47 \mathrm{E}-06$ & $1.67 \mathrm{E}-04$ & 0.02 & 0.03 \\
1.75 & $4.97 \mathrm{E}-07$ & $4.81 \mathrm{E}-05$ & 0.01 & 0.01 \\
\hline
\end{tabular}

The dose rate from Sr-90 comes from the bremsstrahlung X-rays which are produced as the high energy beta particles slow down in the soil.

To compare the dose rates from the four tanks in 241-AX, the contamination was assumed to be at the surface value $(\mathrm{Co})$ down to a depth of $2 \mathrm{ft}$. Various leak radii were used. The soil concentration was assumed to be $1 \mathrm{nCi} / \mathrm{g}$ in all cases. The ISO-PC input file is shown in the second attachment. 
HNF-3378-Rev. 0

\begin{tabular}{|c|c|c|}
\hline \multicolumn{3}{|c|}{ ISO-PC Dose Rates (mrem/h) for Unit Soil Concentrations } \\
\hline Source Radius, $\mathrm{ft}$ & Sr-90 & Cs-137 \\
\hline 2.56 & $1.81 \mathrm{E}-03$ & 0.122 \\
3.97 & $3.21 \mathrm{E}-03$ & 0.219 \\
6.16 & $4.81 \mathrm{E}-03$ & 0.330 \\
9.55 & $6.21 \mathrm{E}-03$ & 0.428 \\
14.8 & $7.23 \mathrm{E}-03$ & 0.500 \\
23.0 & $7.93 \mathrm{E}-03$ & 0.549 \\
$\mathbf{3 5 . 7}$ ( 8,000 gal) & $\mathbf{8 . 3 7 E - 0 3}$ & $\mathbf{0 . 5 8 0}$ \\
$\mathbf{5 5 . 4} \mathbf{( 4 0 , 0 0 0}$ gal) & $\mathbf{8 . 6 6 E - 0 3}$ & $\mathbf{0 . 6 0 0}$ \\
86.0 & $8.84 \mathrm{E}-03$ & 0.613 \\
133 & $8.95 \mathrm{E}-03$ & 0.620 \\
207 & $9.01 \mathrm{E}-03$ & 0.625 \\
321 & $9.05 \mathrm{E}-03$ & 0.628 \\
499 & $9.07 \mathrm{E}-03$ & 0.630 \\
\hline \multicolumn{3}{|c|}{} \\
\hline
\end{tabular}

Using the surface soil concentrations shown on the third table, the dose rates can be computed. The total dose rate is the sum of the products of the soil concentrations and the unit dose rate factors for Sr-90 and Cs-137. Results are shown in the table below.

\begin{tabular}{|c|c|c|c||c|c|c|}
\hline \multicolumn{6}{|c|}{ Dose Rates (mrem/h) from Postulated Leaks at 1 m Above the Center } \\
\hline & \multicolumn{3}{|c|}{8,000 Gallon Leak } & \multicolumn{3}{|c|}{40,000 Gallon Leak } \\
\cline { 2 - 7 } & Sr-90 & Cs-137 & Total & Sr-90 & Cs-137 & Total \\
\hline \hline AX-101 & 18 & 656 & 674 & 37 & 1348 & 1385 \\
\hline AX-102 & 45 & 1312 & 1357 & 92 & 2698 & 2790 \\
\hline AX-103 & 382 & 1154 & 1536 & 785 & 2373 & 3158 \\
\hline AX-104 & 524 & 753 & 1277 & 1078 & 1549 & 2627 \\
\hline
\end{tabular}

The worst-case tank is AX-103, followed closely by AX-102.

One final question is the dose rate at the edge of the circle, rather than directly above the center. ISO-PC cannot compute dose rates at this location. However, since the contamination circles are rather large the effect of going to the edge can be approximated by using the rectangular box geometry, for which an edge calculation can be made. The box geometry always calculates dose rates at the center of the box. The edge dose rate can be computed by doubling the other edge dimension and halving the concentration. The dose rate at the center of the doubled box is the same as the dose rate at the edge of the original box. To represent the two leak cases, the square areas must be $19.27 \mathrm{~m}(63.2 \mathrm{ft})$ and $29.94 \mathrm{~m}(98.2 \mathrm{ft})$ across. 
The dose rates for Sr-90 and Cs- 137 for both leak sizes are shown in the table below. The ISOPC input file is included as the third attachment. The ratio of edge dose rates to center dose rates is 0.51 in all cases. For the circular area the ratio should be slightly less due to the variable gap between adjacent circles with no activity.

\begin{tabular}{|c|c|c|c|}
\hline \multicolumn{4}{|c|}{ Dose Rates (mrem/h) and Ratios for Square Area Sources at } \\
1 m Above the Square \\
\hline \multirow{2}{*}{ Leak Size } & Dose Point & Sr-90 & Cs-137 \\
\hline \multirow{2}{*}{8,000 gallon } & Center & $8.34 \mathrm{E}-03$ & 0.578 \\
\cline { 2 - 4 } & Edge & $4.26 \mathrm{E}-03$ & 0.295 \\
\cline { 2 - 4 } & Ratio & 0.51 & 0.51 \\
\hline \multirow{2}{*}{40,000 gallon } & Center & $8.61 \mathrm{E}-03$ & 0.598 \\
\cline { 2 - 4 } & Edge & $4.37 \mathrm{E}-03$ & 0.303 \\
\cline { 2 - 4 } & Ratio & 0.51 & 0.51 \\
\hline $\begin{array}{l}\text { Note: The surface area of the squares matches the surface area of the circles used } \\
\text { before. } \\
\text { Note: Source concentrations for the "Center" cases is 1.0 nCi/g. Dose rates for the } \\
\text { "Edge" cases were computed by doubling SLTH and halving the source } \\
\text { concentration, since this is geometrically equivalent to a dose rate at the center of } \\
\text { one edge. }\end{array}$
\end{tabular}

Using the factor of 0.51 to estimate dose rates at the edge of the circular areas gives the table shown below.

\begin{tabular}{|c|c|c|c|c|}
\hline \multicolumn{5}{|c|}{ Dose Rates (mrem/h) from Postulated Leaks at 1 m Above the } \\
\hline & 8,000 Gallon Leak & 40,000 Gallon Leak \\
\cline { 2 - 5 } & Edge & Center & Edge & Center \\
\hline AX-101 & 344 & 674 & 706 & 1385 \\
\hline AX-102 & 692 & 1357 & 1423 & 2790 \\
\hline AX-103 & 783 & 1536 & 1611 & 3158 \\
\hline AX-104 & 651 & 1277 & 1340 & 2627 \\
\hline $\begin{array}{l}\text { Note: Dose rates at the edge of the circular area were computed as } \\
0.51 \text { times the dose rate at the center. }\end{array}$
\end{tabular}


HNF-3378-Rev. 0

The dose rates near the postulated leaks are large enough that special methods will be needed to remove the contaminated soil.

\subsection{REFERENCES}

American National Standard for Neutron and Gamma-Ray Fluence-to-Dose Factors, ANSU/ANS-6.1.1-1991, American Nuclear Society, 1991.

American National Standard for Gamma-Ray Attenuation Coefficients and Buildup Factors for Engineering Materials, ANSL/ANS-6.4.3-1991, American Nuclear Society, August, 1991.

Brown, R. C., Soil Density and Mass Attenuation Coefficients for Use in Shielding Calculations at the Hanford Waste Vitrification Plant, WHC-SD-HWV-TI-020, Rev 0, January 1992, Westinghouse Hanford Company, Richland, Washington.

Carter, L. L., "Bulk Shield Design for Neutron Energies Below $50 \mathrm{MeV}$ ", Nuclear Technology/Fusion, Vol. 3, pp 165-180, March 1983.

Carter, L. L., Certification of MCNP Version 4 A for WHC Computer Platforms, WHC-SD-MP-SWD-30001, Rev. 8, May 1996, Westinghouse Hanford Company, Richland, Washington.

Rittmann, P. D., ISO-PC Version 1.98 - User's Guide, WHC-SD-WM-UM-030, Rev 0, May 1995, and Summary of Changes to ISO-PC Version 2.1, February 1996, Westinghouse Hanford Company, Richland, Washington. (Available from the Radiation Safety Information Computer Center as CCC-636)

Van Riper, K. A., SABRINA User's Guide, LA-UR-93-3696, October 1993, Los Alamos National Laboratory, Los Alamos, New Mexico. 
HNF-3378-Rev. 0

ATTACHMENT 1

SKETCHES OF THE MCNP GEOMETRY MODEL 
HNF-3378-Rev. 0

Figure 1. Four Tank Case -- Domes Intact, East-West Plane Through Tanks 103 and 101 Center at $(0 \mathrm{~cm}, 1554 \mathrm{~cm}, 0 \mathrm{~cm})$ Full Width $=4000 \mathrm{~cm}$

Note: Layer above tanks is air. Soil surrounds tanks.

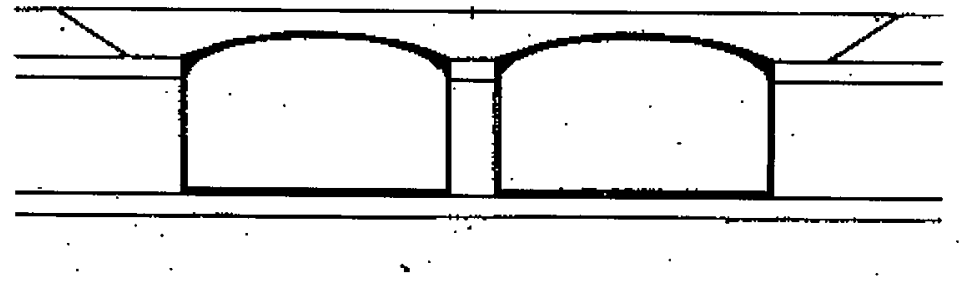


HNF-3378-Rev. 0

Figure 2. Four Tank Case -- Domes Intact, East-West Plane Through Tank 101 Center at $(1372 \mathrm{~cm}, 1554 \mathrm{~cm},-600 \mathrm{~cm})$ Full Width $=2600 \mathrm{~cm}$

Note: Extra surfaces in the tank dome and walls are needed to improve the monte carlo calculation efficiency.

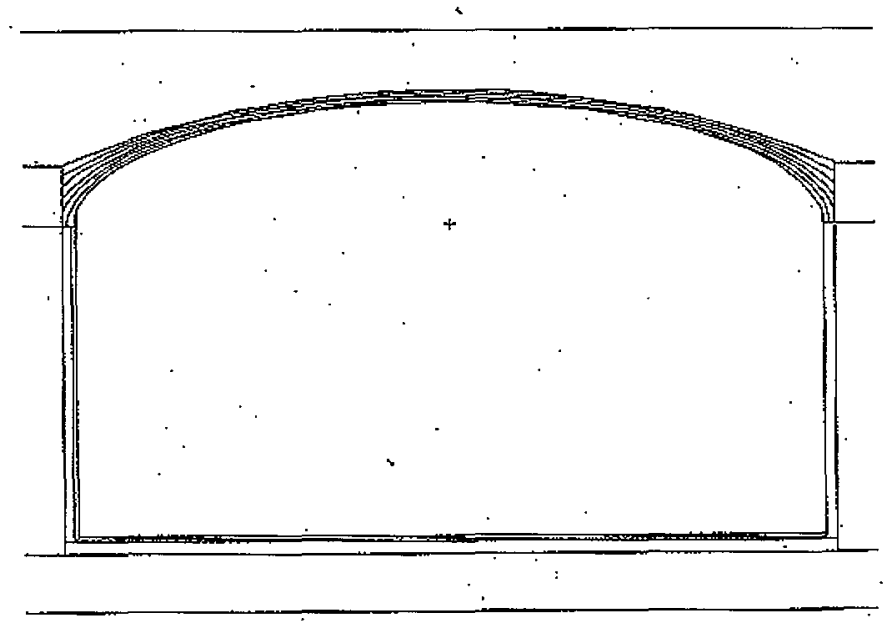


Figure 3. Four Tank Case -- Domes Intact, East-West Plane Through Tanks 103 and 101 Center at $(0 \mathrm{~cm}, 1554 \mathrm{~cm},-512 \mathrm{~cm})$ Full Width $=600 \mathrm{~cm}$

Note: Extra surfaces in the tank dome and walis are needed to improve the monte carlo calculation efficiency. Numbers show the relative importance of the region. Tank walls and dome are made of concrete. Soil lies between the tanks. Air (importance 7338 and 19) lies above and inside the tanks.

7398

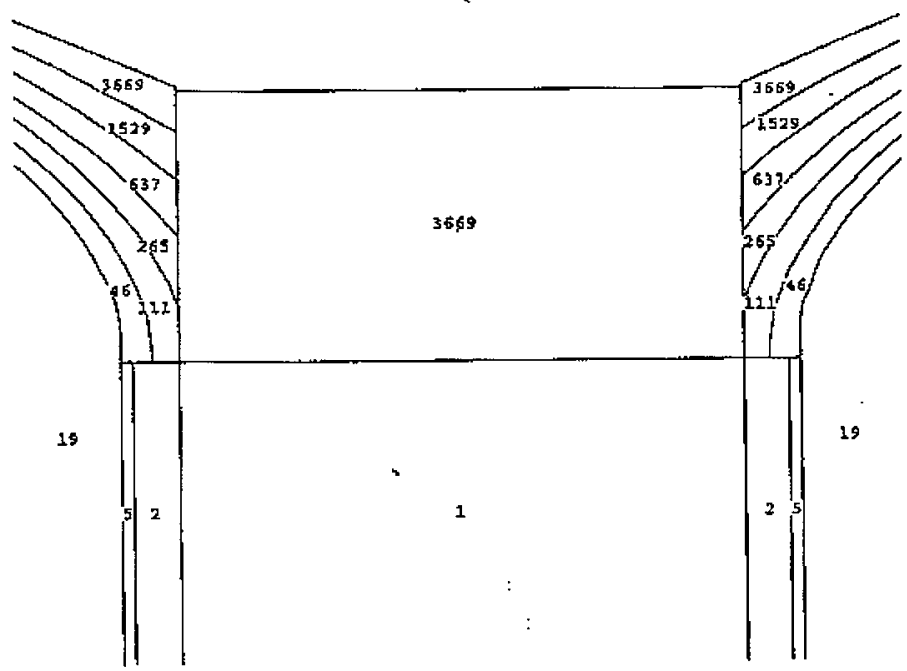


Figure 4. Four Tank Case -- Tank Wall/Base Corner, East-West Plane Through Tank 101 Center at $(215 \mathrm{~cm}, 1554 \mathrm{~cm},-1575 \mathrm{~cm})$ Full Width $=80 \mathrm{~cm}$

Note: Extra surfaces in the tank dome and walls are needed to improve the monte carlo calculation efficiency. Numbers show the material ID: 1=air, 2=soil, 3=concrete, 4=iron, $5=$ waste in $\mathrm{AX}-101$.

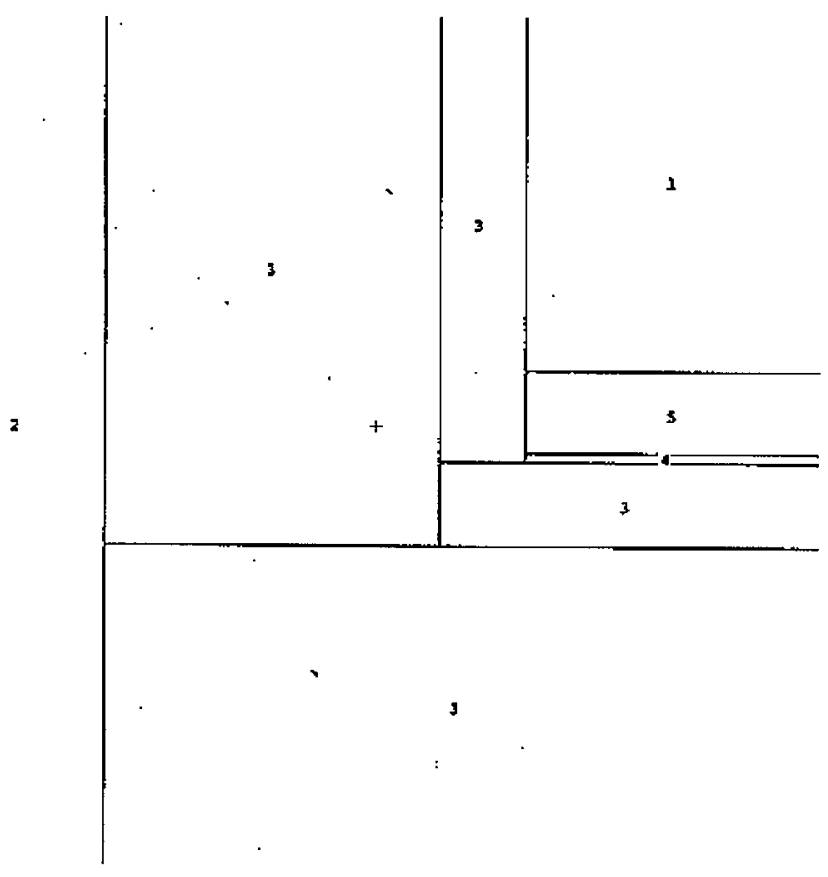


Figure 5. Four Tank Case -- Tank Wall/Base Corner, East-West Plane Through Tank 101 Center at $(215 \mathrm{~cm}, 1554 \mathrm{~cm},-1575 \mathrm{~cm})$ Full Width $=80 \mathrm{~cm}$

Note: Extra surfaces in the tank dome and walls are needed to improve the monte carlo calculation efficiency. Numbers show the relative importance of the regions.

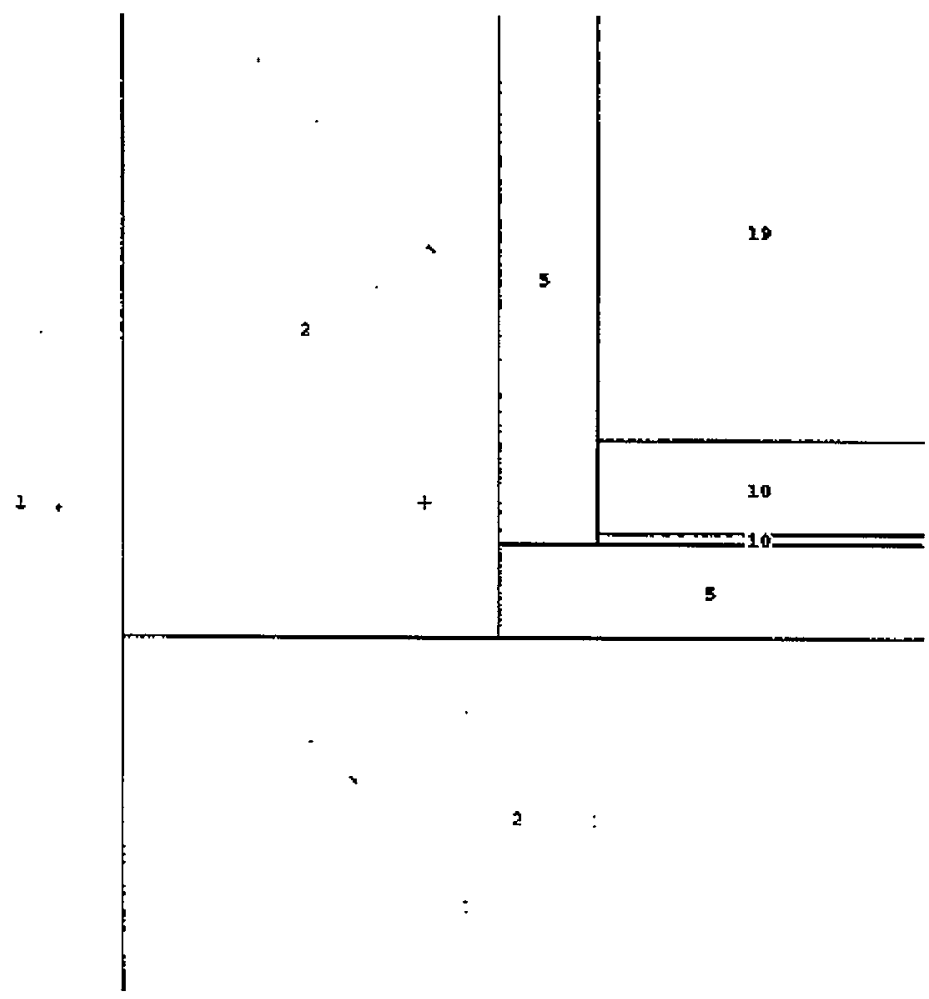


Figure 6. Four Tank Case -- Dome Removed from AX-101, Plane Through Tanks $103 \& 101$

Center at $(0 \mathrm{~cm}, 1554 \mathrm{~cm},-512 \mathrm{~cm})$ Full Width $=600 \mathrm{~cm}$

Note: Extra surfaces in the tank dome and walls are needed to improve the monte carlo calculation efficiency. Numbers show the relative importance of the regions.

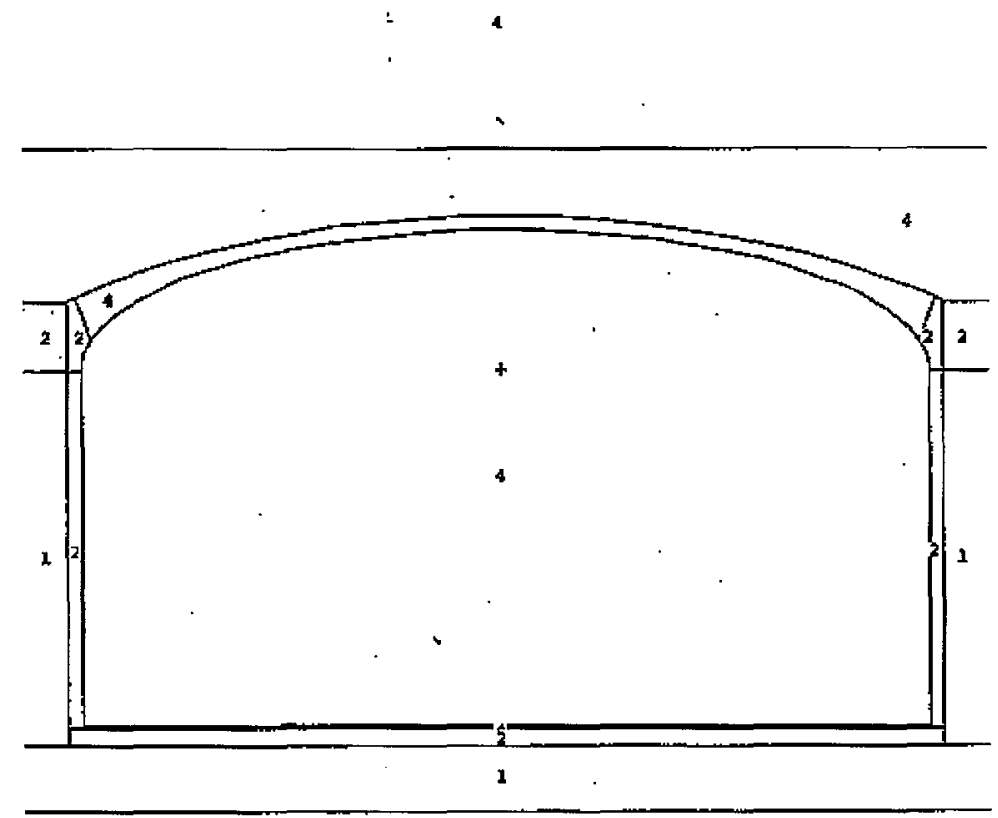

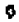


Figure 7. SABRINA 3-D Sketch of the Four Tank Case with AX-101 Dome Removed

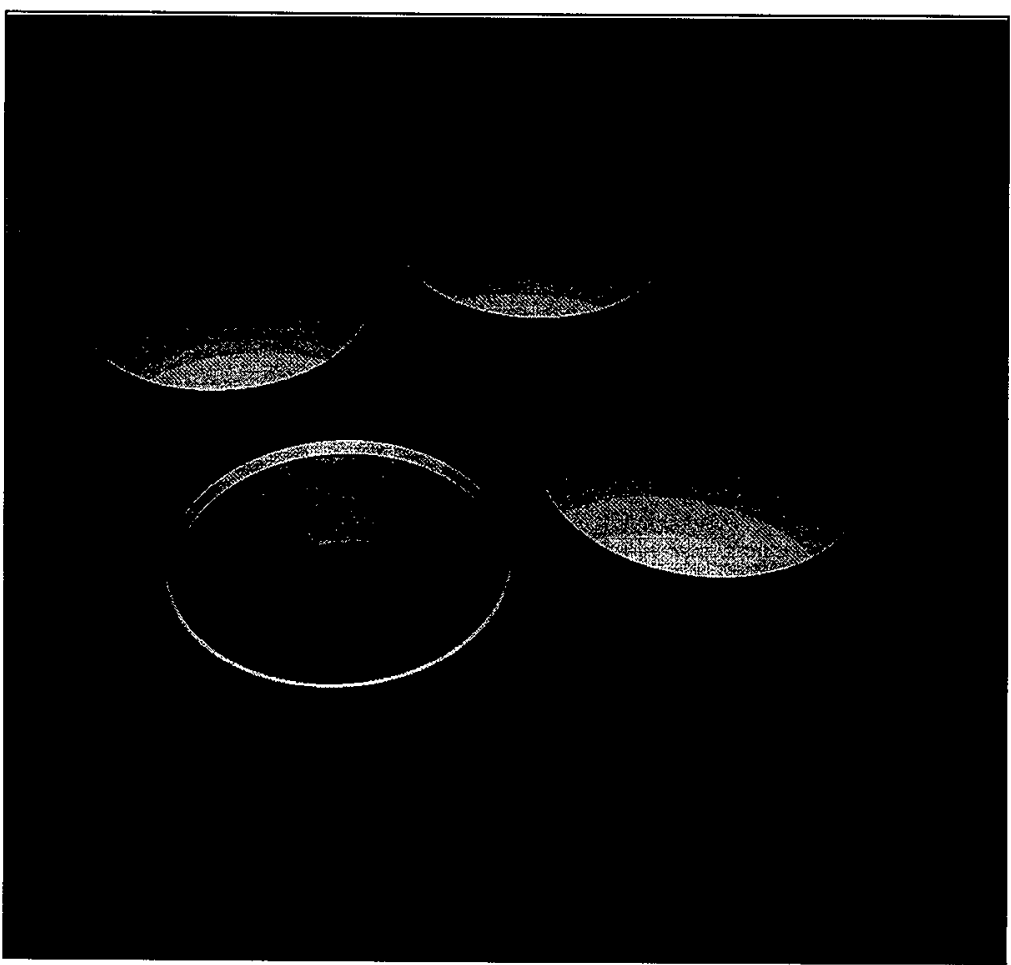


HNF-3378-Rev. 0

\section{ATTACHMENT 2}

\section{LISTING OF SELECTED MCNP INPUT FILES}




\section{Table 15. Four Tank Case -- Dome Intact, AX-101 Source}

241-AX Tank Farm with Domes

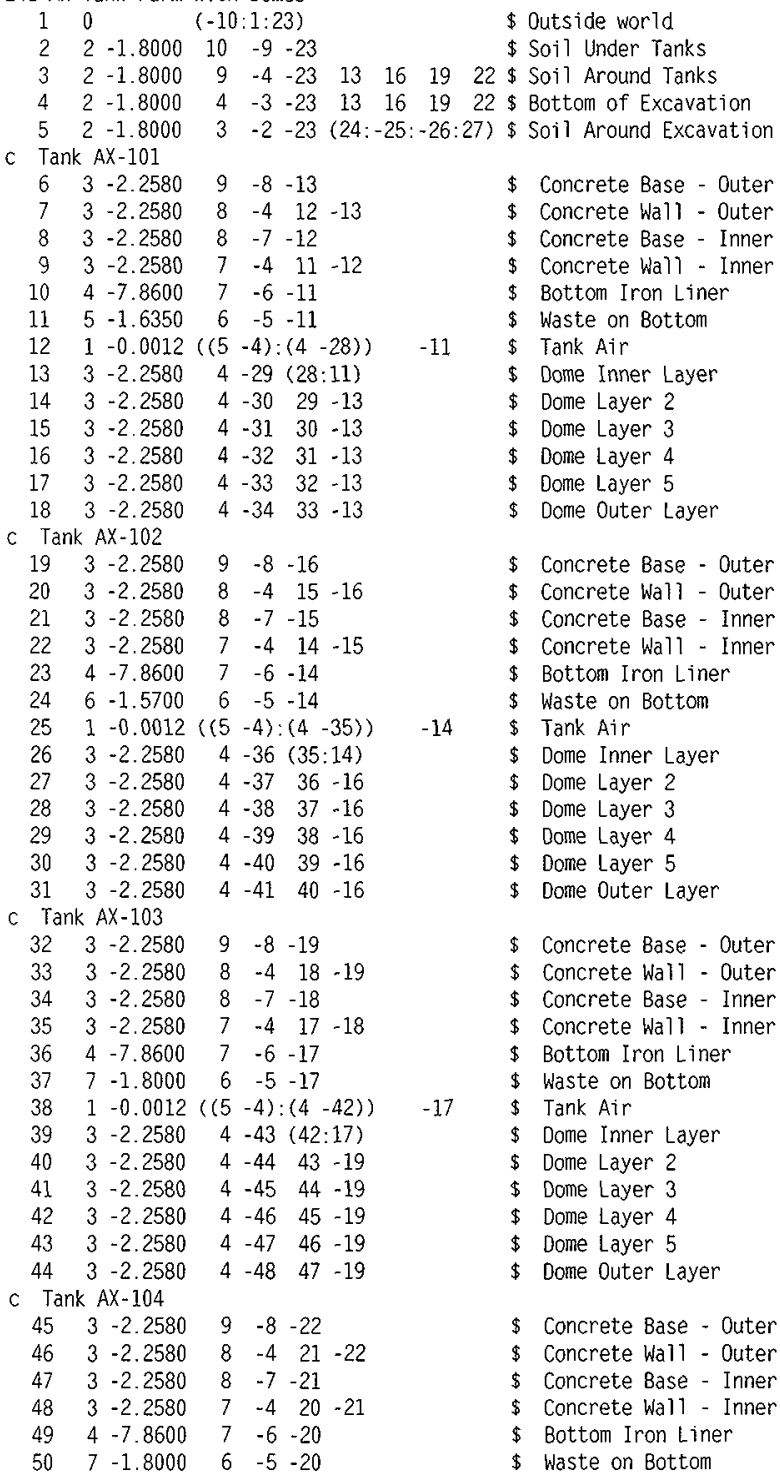




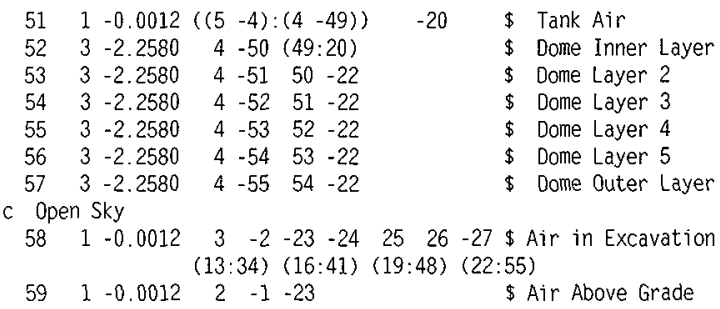

c Horizontal Planes

\begin{tabular}{|c|c|c|c|}
\hline $1 \mathrm{PZ}$ & 30480.0 & $\$$ & Upper Boundary \\
\hline $2 P Z$ & 0.00 & $\$$ & Ground Surface \\
\hline $3 \mathrm{P}$ & -418.15 & $\$$ & Excavation Depth \\
\hline $\mathrm{p}$ & -604.52 & $\$$ & Center of Inner Ellipsoid \\
\hline$D$ & -1569.72 & $\$$ & Upper Waste Surface \\
\hline $6 \mathrm{P}$ & -1577.34 & $\$$ & Lower Waste Surface \\
\hline n & -1578.29 & $\$$ & Iron/Concrete Boundary \\
\hline & -1585.91 & $\$$ & Weighting Surface \\
\hline $9 p$ & -1623.06 & $\$$ & Bottom of Tank \\
\hline 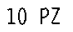 & -1805.94 & $\$$ & Lower Boundary \\
\hline
\end{tabular}

c Vertical Cylinders

$\begin{array}{llllll}11 \mathrm{C} / \mathrm{Z} & 1371.60 & 1554.48 & 1143.00 & \$ \text { AX-101 Inner Surface } \\ 12 \mathrm{C} / \mathrm{Z} & 1371.60 & 1554.48 & 1150.62 & \$ \text { Weighting Surface } \\ 13 \mathrm{C} / \mathrm{Z} & 1371.60 & 1554.48 & 1181.10 & \$ \text { Outer Surface } \\ 14 \mathrm{C} / \mathrm{Z} & 1371.60 & -1554.48 & 1143.00 & \$ \text { AX-102 Inner Surface } \\ 15 \mathrm{C} / \mathrm{Z} & 1371.60 & -1554.48 & 1150.62 & \$ \text { Weighting Surface } \\ 16 \mathrm{C} / \mathrm{Z} & 1371.60 & -1554.48 & 1181.10 & \$ \text { Outer Surface } \\ 17 \mathrm{C} / \mathrm{Z} & -1371.60 & 1554.48 & 1143.00 & \$ \text { AX-103 Inner Surface } \\ 18 \mathrm{C} / \mathrm{Z} & -1371.60 & 1554.48 & 1150.62 & \$ \text { Weighting Surface } \\ 19 \mathrm{C} / 2 & -1371.60 & 1554.48 & 1181.10 & \$ \text { Outer Surface } \\ 20 \mathrm{C} / 2 & -1371.60 & -1554.48 & 1143.00 & \$ \text { AX-104 Inner Surface } \\ 21 \mathrm{C} / \mathrm{Z} & -1371.60 & -1554.48 & 1150.62 & \$ \text { Weighting Surface } \\ 22 \mathrm{C} / \mathrm{Z} & -1371.60 & -1554.48 & 1181.10 & \$ \text { Outer Surface } \\ 23 \mathrm{CZ} & 30480.00 & \$ & \text { Outer Boundary } & & \end{array}$

C Sloped Planes

$\begin{array}{rrrrrll}24 & P & 2.00 & 0.00 & -3.00 & 7274.24 & \$ \text { East Side } \\ 25 \rho & 0.00 & 2.00 & 3.00 & -7640.00 & \$ & \text { South Side } \\ 26 P & 2.00 & 0.00 & 3.00 & -7274.24 & \$ \text { West Side } \\ 27 \rho & 0.00 & 2.00 & -3.00 & 7640.00 & \$ \text { North Side }\end{array}$

C Ellipsoids for Tank Domes

\begin{tabular}{|c|c|c|c|c|c|c|c|}
\hline 2 & DL. & & & 0 & & U & -19303757128 \\
\hline & 1371.60 & 1554.48 & -604.52 & & & $\$$ & AX-101 Inner \\
\hline S & 154001.3 & 154001.3 & 1356269.9 & 0 & 0 & 0 & -208867 \\
\hline & & 1554.48 & -607.06 & & & $\$$ & Layer 1 \\
\hline 5 & 163 & 1631 & 1413055.2 & 0 & & 0 & -230473 \\
\hline & & 15 & -61 & & & $\$$ & Layer 2 \\
\hline & 1767 & 1767 & 14864 & 0 & & 0 & -2626717 \\
\hline & & & & & & $\$$ & Layer 3 \\
\hline & 213 & 213 & 16388 & 0 & 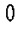 & 0 & -350218 \\
\hline & & 15 & & & & $\$$ & Layer 4 \\
\hline $33 \mathrm{~s}$ & 3108 & 3108 & 1965828.3 & 0 & 0 & 0 & -6110574 \\
\hline & & & & & & $\$$ & Laye \\
\hline $4 \mathrm{~s}$ & 741424.32 & 74142 & 29744 & 0 & 0 & 0 & -220533 \\
\hline & & & & & & 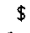 & Upper \\
\hline & 14730 & 171 & 13122 & 0 & & & 100 \\
\hline
\end{tabular}


HNF-3378-Rev. 0

\begin{tabular}{|c|c|c|c|c|c|c|c|}
\hline & & 1554.48 & -604.52 & & & $\$$ & $0<$ \\
\hline \multirow[t]{2}{*}{$36 \mathrm{SQ}$} & & 154001.3 & 56269.9 & 0 & 0 & 0 & -20886732948 \\
\hline & & -1554.48 & -607.06 & & & $\$$ & Layer 1 \\
\hline \multirow[t]{2}{*}{$37 \mathrm{SQ}$} & 1631 & 163102.9 & 1413055.2 & 0 & v & 0 & \\
\hline & & .48 & & & & $\$$ & Layer 2 \\
\hline \multirow[t]{2}{*}{$38 \mathrm{SQ}$} & 17671 & 1767 & 1486448.6 & 0 & & 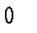 & -262671 \\
\hline & & & & & & $\$$ & Layer 3 \\
\hline \multirow[t]{2}{*}{39 SQ } & 213 & 2.8 & 16388 & 0 & & 0 & -350218 \\
\hline & & & & & & $\$$ & Layer 4 \\
\hline \multirow[t]{2}{*}{$40 \mathrm{SQ}$} & 3108 & 9.7 & 19658 & 0 & & . & -611057 \\
\hline & & .48 & & & & $\$$ & Laye \\
\hline \multirow[t]{2}{*}{$41 \mathrm{SQ}$} & 74142 & 74142 & 29744 & 0 & & 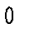 & -22 \\
\hline & & 48 & -10 & & & $\$$ & Uppe \\
\hline \multirow[t]{2}{*}{42 SQ } & 1471 & 14710 & 13122 & 0 & & 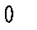 & -19 \\
\hline & & & & & & $\$$ & $A X-1$ \\
\hline \multirow[t]{2}{*}{$43 S Q$} & & 154 & 1356 & 0 & & 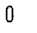 & -208867 \\
\hline & & & & & & $\$$ & Laye \\
\hline \multirow[t]{2}{*}{$44 \mathrm{SQ}$} & 9 & 163 & 1413 & 0 & & 0 & -23 \\
\hline & & & & & & $\$$ & Laye \\
\hline \multirow[t]{2}{*}{$45 \mathrm{SQ}$} & 176 & 1767 & 14864 & 0 & & 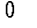 & -26 \\
\hline & & & 3 & & & $\$$ & Layer \\
\hline \multirow[t]{2}{*}{$46 \mathrm{SQ}$} & 213 & 2137 & 16388 & 0 & & 0 & -3502 \\
\hline & & 8 & & & & $\$$ & Layer \\
\hline \multirow[t]{2}{*}{$47 \mathrm{SQ}$} & 7 & 3108 & 19658 & 0 & & 0 & -6110574 \\
\hline & 0 & 48 & & & & $\$$ & Layer \\
\hline \multirow[t]{2}{*}{$48 \mathrm{SO}$} & 7414 & 741424.32 & 2974 & 0 & 0 & 0 & -220 \\
\hline & & 4.48 & 94 & & & $\$$ & Uppe \\
\hline \multirow[t]{2}{*}{$49 \mathrm{SQ}$} & 14710 & 147102.93 & 1312261.9 & 0 & 0 & 0 & 37571281.32 \\
\hline & & & & & & $\$$ & $A X-1$ \\
\hline \multirow[t]{2}{*}{$50 \mathrm{SQ}$} & 154001.3 & 154001.3 & 1356269.9 & 0 & 0 & 0 & -208867329483.9 \\
\hline & & & & & & $\$$ & Layer 1 \\
\hline \multirow[t]{2}{*}{$51 \mathrm{SQ}$} & 163102.9 & 163102.9 & 1413055.2 & 0 & 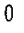 & 0 & -230473406678.0 \\
\hline & & & & & & $\$$ & Layer 2 \\
\hline \multirow[t]{2}{*}{$52 \mathrm{SQ}$} & 176710.94 & 176710.94 & 1486448.6 & 0 & 0 & 0 & -262671731828.13 \\
\hline & & & & & & $\$$ & Layer 3 \\
\hline \multirow[t]{2}{*}{$53 \mathrm{SQ}$} & 213702.8 & 213702.8 & 1638809.6 & 0 & 0 & 0 & -350218203035.5 \\
\hline & & & & & & $\$$ & Layer 4 \\
\hline \multirow[t]{2}{*}{$54 \mathrm{SO}$} & 310839.7 & 310839.7 & 1965828.3 & 0 & 0 & 0 & -611057488998.9 \\
\hline & -1371.60 & $-1554,48$ & & & & $\$$ & Layer 5 \\
\hline \multirow[t]{2}{*}{$55 \mathrm{SO}$} & 741424.32 & 741424.32 & 2974452.1 & 0 & 0 & 0 & -220533114788 \\
\hline & 60 & -1554.48 & -1043.94 & & & $\$$ & Upper Surf \\
\hline
\end{tabular}

m1 \$ Air at $80^{\circ} \mathrm{F}$ and $20.0 \%$ Relative Humidity

$\begin{array}{rrll}1001.01 p & -0.00048 & \$ \text { Hydrogen } \\ 6012.01 p & -0.00014 & \$ & \text { Carbon } \\ 7014.01 p & -0.75191 & \$ \text { Nitrogen } \\ 8016.01 p & -0.23464 & \$ & \text { Oxygen } \\ 18040.01 p & -0.01282 & \$ \text { Argon }\end{array}$

m2 \$ Hanford Soil with $0.10 \mathrm{ml} / \mathrm{cc}$ Water $1001.01 p \quad-0.00617$ \& Hydrogen $8016.01 p-0.47331$ \$ Oxygen $11023.01 \mathrm{p} \quad-0.01678 \$$ Sodium $12000.01 p-0.02722 \$$ Magnesium $13027.01 p-0.06864 \$$ Aluminum $14000.01 p \quad-0.22887$ \$ Silicon 15031.01p -0.00222 \$ Phosphorus $19000.010 \quad-0.01068 \$$ Potassium 20000.01p $-0.05969 \$$ Calcium 


\begin{tabular}{|c|c|c|c|c|c|}
\hline & & $22000.01 p$ & -0.01425 & $\$$ & Titanium \\
\hline & & $25055.01 p$ & -0.00151 & $\$$ & Manganese \\
\hline & & $26000.01 p$ & -0.09064 & $\$$ & Iron \\
\hline \multirow[t]{14}{*}{$\mathrm{m} 3$} & $\$$ & \multicolumn{4}{|c|}{ Hanford Concrete } \\
\hline & & $1001.01 p$ & -0.00310 & $\$$ & Hydrogen \\
\hline & & $8016.01 p$ & -0.44070 & $\$$ & 0xygen \\
\hline & & $11023.01 p$ & -0.01820 & $\$$ & Sodium \\
\hline & & $12000.01 p$ & -0.03760 & $\$$ & Magnesium \\
\hline & & $13027.01 p$ & -0.06070 & $\$$ & Aluminum \\
\hline & & $14000.01 p$ & -0.21570 & $\$$ & silicon \\
\hline & & $15031.01 p$ & -0.00090 & $\$$ & Phosphorus \\
\hline & & $16032.01 \mathrm{p}$ & -0.00090 & $\$$ & SuTfur \\
\hline & & $20000.01 p$ & -0.13060 & $\$$ & Calcium \\
\hline & & $22000.01 p$ & -0.00490 & $\$$ & Titanium \\
\hline & & $25055.01 p$ & -0.00130 & $\$$ & Manganese \\
\hline & & $26000.01 p$ & -0.07880 & $\$$ & Iron \\
\hline & & $36000.01 p$ & -0.00660 & $\$$ & Krypton \\
\hline \multirow{2}{*}{$m 4$} & $\$$ & Plain Iron & & & \\
\hline & & $26000.01 p$ & -1.00 & & \\
\hline \multirow[t]{21}{*}{ m5 } & $\$$ & Tank Residua] & Sludge: & \multicolumn{2}{|c|}{$A X-101$} \\
\hline & & $1001.01 p$ & -0.03811 & $\$$ & Hydrogen \\
\hline & & $6012.01 p$ & -0.03390 & $\$$ & Carbon \\
\hline & & $7014.01 p$ & -0.22079 & $\$$ & Nitrogen \\
\hline & & $8016.01 p$ & -0.42709 & $\$$ & oxygen \\
\hline & & $11023.01 p$ & -0.15815 & $\$$ & Sodium \\
\hline & & $13027.01 \mathrm{p}$ & -0.02778 & $\$$ & Aluminum \\
\hline & & $14000.01 p$ & -0.01014 & $\$$ & Silicon \\
\hline & & $15031.01 p$ & -0.01038 & $\$$ & Phosphorus \\
\hline & & $16032.01 p$ & -0.00468 & $\$$ & Sulfur \\
\hline & & $17000.01 p$ & -0.00828 & $\$$ & Chlorine \\
\hline & & $19000.01 p$ & -0.00300 & $\$$ & Potassium \\
\hline & & $20000.01 \mathrm{p}$ & -0.00162 & $\$$ & Calcium \\
\hline & & $24000.01 p$ & -0.00744 & $\$$ & Chromium \\
\hline & & 25055.010 & -0.00282 & $\$$ & Manganese \\
\hline & & $26000.01 p$ & -0.01704 & $\$$ & Iron \\
\hline & & $28000.01 p$ & -0.00048 & $\$$ & Nickel \\
\hline & & $36000.01 p$ & -0.00102 & $\$$ & Krypton \\
\hline & & $56000.01 p$ & -0.00094 & $\$$ & Barium \\
\hline & & $82000.01 p$ & -0.00234 & $\$$ & Lead \\
\hline & & $92238.01 p$ & -0.02400 & $\$$ & Uranium \\
\hline
\end{tabular}

m6 \$ Tank Residual Sludge: AX-102

$\begin{array}{rlll}1001.01 p & -0.04722 & \$ \text { Hydrogen } \\ 6012.01 p & -0.01731 & \$ \text { Carbon } \\ 7014.01 p & -0.03693 & \$ \text { Nitrogen } \\ 8016.01 p & -0.64925 & \$ \text { Oxygen } \\ 11023.01 p & -0.07560 & \$ \text { Sodium } \\ 13027.01 p & -0.03093 & \$ \text { Aluminum } \\ 14000.01 p & -0.02249 & \$ \text { Silicon } \\ 15031.01 p & -0.00147 & \$ \text { Phosphorus } \\ 16032.01 p & -0.00209 & \$ \text { Sulfur } \\ 17000.01 p & -0.00075 & \$ \text { Chlorine } \\ 19000.01 p & -0.00018 & \$ \text { Potassium } \\ 20000.01 p & -0.00506 & \$ \text { Calcium } \\ 24000.01 p & -0.00015 & \$ \text { Chromium } \\ 25055.01 p & -0.00762 & \$ \text { Manganese } \\ 26000.01 p & -0.09060 & \$ \text { Iron } \\ 28000.01 p & -0.00344 & \$ \text { Nickel } \\ 92238.01 p & -0.00890 & \$ \text { Uranium }\end{array}$


HNF-3378-Rev. 0

m7 \$ Tank Residual S1udge: AX-103 \& AX-104

$\begin{array}{rlll}1001.01 p & -0.04722 & \$ \text { Hydrogen } \\ 7014.01 p & -0.00213 & \$ & \text { Nitrogen } \\ 8016.01 p & -0.62394 & \$ \text { 0xygen } \\ 11023.01 p & -0.04262 & \$ & \text { Sodium } \\ 12000.01 p & -0.00229 & \$ & \text { Magnesium } \\ 13027.01 p & -0.03706 & \$ \text { Aluminum } \\ 14000.01 p & -0.03875 & \$ \text { Silicon } \\ 15031.01 p & -0.00583 & \$ \text { Phosphorus } \\ 16032.01 p & -0.00719 & \$ \text { Sulfur } \\ 20000.01 p & -0.01455 & \$ \text { Calcium } \\ 24000.01 p & -0.00174 & \$ \text { Chromium } \\ 25055.01 p & -0.00256 & \$ \text { Manganese } \\ 26000.01 p & -0.16404 & \$ \text { Iron } \\ 28000.01 p & -0.00850 & \$ \text { Nicke1 } \\ 56000.01 p & -0.00158 & \$ \text { Barium }\end{array}$

mode 0

print $40 \quad 120$

promp $\quad j \quad j \quad 1$

phys:p $\quad j \quad 1 \quad 1$

imp:p $\quad 0111366936692225510101946111265637 \quad 15293669$

22551010194611126563715293669

22551010194611126563715293669

2255101019461112656371529366973387338

nps 600000

sdef $w g t=6.74 \mathrm{E}+13$ cel $=11$ erg $=\mathrm{d} 1$ pos $=\mathrm{d} 2$ ext $=\mathrm{d} 3 \mathrm{rad}=\mathrm{d} 4 \mathrm{axs}=\mathrm{d} 5$

SCl Source Energy Distribution for AX-101

$\begin{array}{ccc}\text { \# } & \text { sil } & \text { spl } \\ \mathrm{L} & \mathrm{D} \\ 0.0447 & 1.82 \mathrm{E}+12 \\ 0.0548 & 1.33 \mathrm{E}+12 \\ 0.0649 & 1.13 \mathrm{E}+12 \\ 0.0749 & 1.03 \mathrm{E}+12 \\ 0.0849 & 9.29 \mathrm{E}+11 \\ 0.0949 & 8.35 \mathrm{E}+11 \\ 0.1379 & 4.18 \mathrm{E}+12 \\ 0.2433 & 1.30 \mathrm{E}+12 \\ 0.3450 & 6.30 \mathrm{E}+11 \\ 0.4663 & 4.81 \mathrm{E}+11 \\ 0.6615 & 5.33 \mathrm{E}+13 \\ 0.8179 & 1.07 \mathrm{E}+11 \\ 0.9869 & 7.30 \mathrm{E}+10 \\ 1.2437 & 2.01 \mathrm{E}+11 \\ 1.4499 & 1.26 \mathrm{E}+10 \\ 1.7412 & 1.20 \mathrm{E}+10 \\ 1.8695 & 6.44 \mathrm{E}+08 \\ 2.1681 & 4.29 \mathrm{E}+08\end{array}$

SC2 POS - source position (center of base)

$\begin{array}{llll}\text { si2 L } & 1371.60 & 1554.48 & -1577.34\end{array}$

Sp2 $D \quad 1$

sc3 EXT - source axial distribution (uniform)

Si3 L $\quad 0.0 \quad 7.62$

SC4 RAD - source radial distribution (uniform)

si4 L $\quad 0.0 \quad 1051.56 \$ 3 \mathrm{ft}$ from inner tank wall

sp4 D $\quad-21 \quad 1$

sc5 AXS - direction of cylinder axis (vertical)

$\begin{array}{llll}\text { si5 L } & 0.0 & 0.0 & 1.0\end{array}$

sp5 $0 \quad 1$ 
c Detector Locations 3 feet above surface.

fc05 Over the Center of the Tank Dome

f05:p $\begin{array}{rrrrrr}1371.60 & 1554.48 & -91.44 & 10.0 & \$ & \text { AX-101 } \\ 1371.60 & -1554.48 & -91.44 & 10.0 & \$ & A X-102 \\ -1371.60 & 1554.48 & -91.44 & 10.0 & \$ & \text { AX-103 } \\ -1371.60 & -1554.48 & -91.44 & 10.0 & \$ & \text { AX-104 }\end{array}$

fc15 Halfway between Center \& Tank Edge

f15:p $\begin{array}{rrrrrr}1371.60 & 2125.98 & -140.09 & 10.0 & \$ \text { AX-101 north } \\ 1371.60 & -2125.98 & -140.09 & 10.0 & \$ & \text { AX-102 south } \\ -1371.60 & 2125.98 & -140.09 & 10.0 & \$ \text { AX-103 north } \\ -1371.60 & -2125.98 & -140.09 & 10.0 & \$ \text { AX-104 south }\end{array}$

fc25 Over the Inner Edge of the Tank Dome

$\begin{array}{rrrrrrr}f 25: p & 2514.60 & 1554.48 & -307.70 & 10.0 & \$ A X-101 \text { east } \\ & 2514.60 & -1554.48 & -307.70 & 10.0 & \$ & A X-102 \text { east } \\ & -2514.60 & 1554.48 & -307.70 & 10.0 & \$ & A X-103 \text { west } \\ & -2514.60 & -1554.48 & -307.70 & 10.0 & \$ & A X-104 \text { west } \\ \text { fc35 } & N-S \text { Line Between Tanks } & & & \end{array}$

f35:p $\begin{array}{rrrrrl}0.00 & 6868.00 & 91.44 & 10.0 & \$ 100 \mathrm{ft} N \text { of Excavation } \\ & 0.00 & 5344.00 & 91.44 & 10.0 & \$ 50 \mathrm{ft} N \text { of Excavation } \\ 0.00 & 3820.00 & 91.44 & 10.0 & \$ \text { N Edge of Excavation } \\ 0.00 & 1554.48 & -326.71 & 10.0 & \$ \text { Between AX-101 \& AX-103 } \\ 0.00 & 0.00 & -326.71 & 10.0 & \$ \text { Center Point } \\ 0.00 & -1554.48 & -326.71 & 10.0 & \$ \text { Between AX-102 \& AX-104 } \\ 0.00 & -3820.00 & 91.44 & 10.0 & \$ \text { S Edge of Excavation } \\ & 0.00 & -5344.00 & 91.44 & 10.0 & \$ 50 \mathrm{ft} S \text { of Excavation } \\ & 0.00 & -6868.00 & 91.44 & 10.0 & \$ 100 \mathrm{ft} S \text { S Excavation }\end{array}$

fc45 E-W Line Between Tanks

$\begin{array}{rlrrrl}f 45: \mathrm{p} & 6685.12 & 0.00 & 91.44 & 10.0 & \$ 100 \mathrm{ft} \text { E of Excavation } \\ 5161.12 & 0.00 & 91.44 & 10.0 & \$ 50 \mathrm{ft} \text { E of Excavation } \\ 3637.12 & 0.00 & 91.44 & 10.0 & \$ \text { E Edge of Excavation } \\ 1371.60 & 0.00 & -326.71 & 10.0 & \$ \text { Between AX-101 \& AX-102 } \\ -1371.60 & 0.00 & -326.71 & 10.0 & \$ \text { Between AX-103 \& AX-104 } \\ -3637.12 & 0.00 & 91.44 & 10.0 & \$ \text { W Edge of Excavation } \\ -5161.12 & 0.00 & 91.44 & 10.0 & \$ 50 \mathrm{ft} W \text { of Excavation } \\ -6685.12 & 0.00 & 91.44 & 10.0 & \$ 100 \mathrm{ft} W \text { of Excavation }\end{array}$

fc55 Other Points Near Edge of Excavation

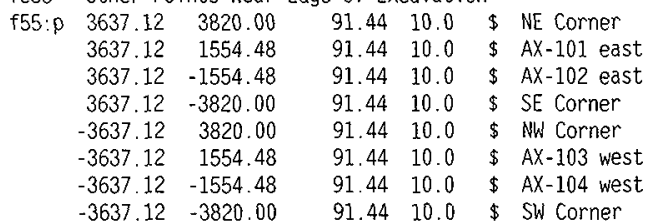

c Bins for Photon Tallies

$\begin{array}{lllllllllll}\text { e0 } & 0.03 & 0.05 & 0.07 & 0.10 & 0.13 & 0.16 & 0.20 & 0.25 & 0.30 & 0.40\end{array}$

$\begin{array}{llllll}0.50 & 0.70 & 1.00 & 1.50 & 2.00 & 2.50\end{array}$

c ANSI/ANS-6.1.1-1991 fluence-to-dose. photons (mrem $/ \mathrm{hr} /\left(\mathrm{p} / \mathrm{cm}^{\star \star 2} / \mathrm{s}\right)$

$\begin{array}{cllllll}\text { de } 0 \quad \log & 0.01 & 0.015 & 0.02 & 0.03 & 0.04 & 0.05 \\ & 0.06 & 0.08 & 0.10 & 0.15 & 0.20 & 0.30 \\ & 0.40 & 0.50 & 0.60 & 0.80 & 1.0 & 1.5 \\ & 2.0 & 3.0 & 4.0 & 5.0 & 6.0 & 8.0\end{array}$

df0 $\quad \log 2.232 e-5 \quad 5.652 e-5 \quad 8.568 e-5 \quad 1.184 e-4 \quad 1.314 e-4 \quad 1.382 e-4$

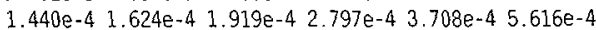

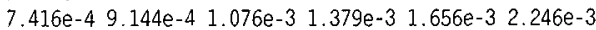

$2.758 \mathrm{e}-3 \quad 3.672 \mathrm{e}-3 \quad 4.500 \mathrm{e}-3 \quad 5.292 \mathrm{e}-3 \quad 6.012 \mathrm{e}-3 \quad 7.488 \mathrm{e}-3$ 
Table 16. Four Tank Case -- Dome Removed, AX-103 Source

241-AX Tank Farm - Dome Removed from AX-103

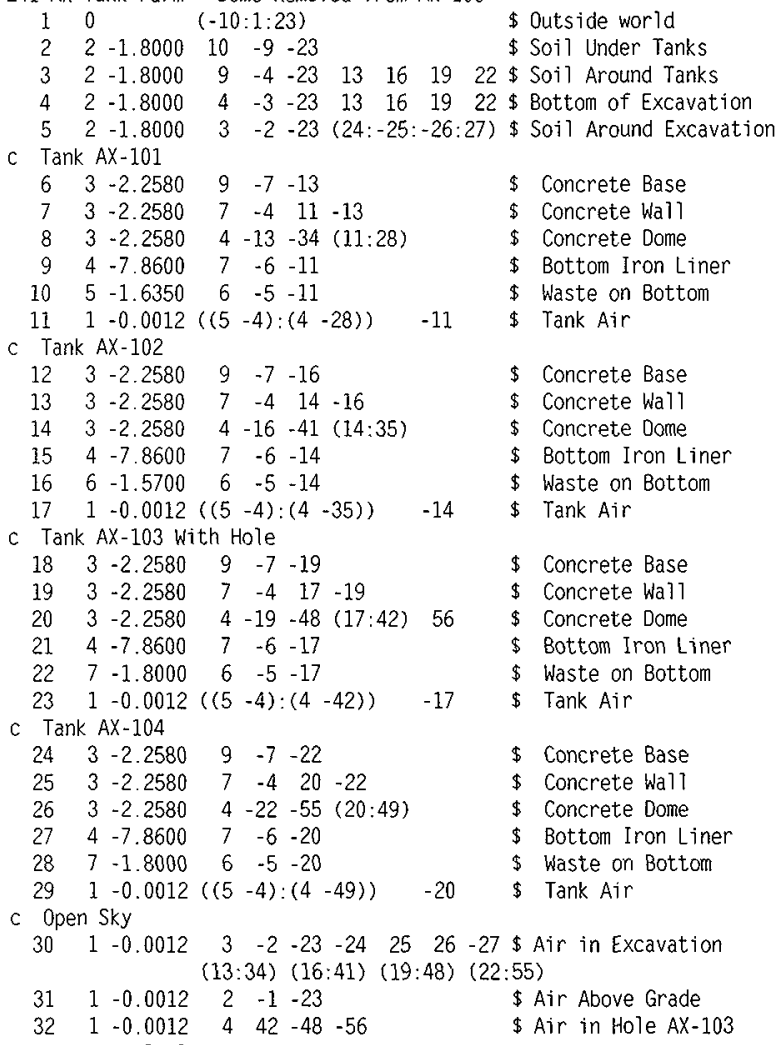

c Horizontal Planes

$1 \mathrm{PZ} \quad 30480.0 \$$ Upper 8oundary

$2 \mathrm{PZ} \quad 0.00 \$$ Ground Surface

$3 \mathrm{PZ}-418.15 \$$ Excavation Depth

$4 \mathrm{Pz}-604.52$ \$ Center of Inner Ellipsoid

$5 \mathrm{PZ}-1569.72 \$$ Upper Waste Surface

$6 \mathrm{PZ}-1577.34$ \$ Lower Waste Surface

$7 \mathrm{Pz}-1578.29 \$$ Iron/Concrete Boundary

$9 \mathrm{PZ}-1623.06 \$$ Bottom of Tank

$10 \mathrm{PZ}-1805.94 \$$ Lower Boundary

C Vertical Cylinders

\begin{tabular}{|c|c|c|c|c|c|}
\hline 12 & 1371.60 & 1554.48 & 1143.00 & $\$$ & eace \\
\hline & & 75 & 1.10 & $\$$ & \\
\hline & & & & $\$$ & s \\
\hline & 13 & & 1.10 & $\$$ & out \\
\hline & .60 & $1554 \quad 48$ & 3.00 & 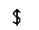 & 证 \\
\hline
\end{tabular}




$\begin{array}{lrrrrl}19 \mathrm{C} / 2 & -1371.60 & 1554.48 & 1181.10 & \$ & \text { Outer Surface } \\ 20 \mathrm{C} / 2 & -1371.60 & -1554.48 & 1143.00 & \$ & \text { AX-104 Inner Surface } \\ 22 \mathrm{C} / 2 & -1371.60 & -1554.48 & 1181.10 & \$ & \text { Outer Surface } \\ 23 \mathrm{CZ} & 30480.00 & \$ & \text { Outer Boundary } & & \\ \mathrm{C} \text { Sloped Planes } & & & & \\ 24 \mathrm{P} & 2.00 & 0.00 & -3.00 & 7274.24 & \$ \text { East Side } \\ 25 \mathrm{P} & 0.00 & 2.00 & 3.00 & -7640.00 & \$ \text { South Side } \\ 26 \mathrm{P} & 2.00 & 0.00 & 3.00 & -7274.24 & \$ \text { West Side } \\ 27 \mathrm{P} & 0.00 & 2.00 & -3.00 & 7640.00 & \$ \text { North Side }\end{array}$

C Ellipsoids for Tank Domes

\begin{tabular}{|c|c|c|c|c|c|c|c|}
\hline SO & $\begin{array}{r}147102.93 \\
1371.60\end{array}$ & $\begin{array}{r}147102.93 \\
1554.48\end{array}$ & $\begin{array}{r}1312261.9 \\
-604.52\end{array}$ & 0 & 0 & ${ }^{0}$ & $\begin{array}{l}-193037571281.32 \\
\text { AX-10] Inner }\end{array}$ \\
\hline SO & 741424.32 & 741424.32 & 2974452.1 & 0 & 0 & 0 & -2205331147889.3 \\
\hline & 1371.60 & 1554.48 & -1043.94 & & & $\$$ & Upper \\
\hline$s 0$ & $\begin{array}{r}147102.93 \\
1371.60\end{array}$ & $\begin{array}{r}147102.93 \\
-1554.48\end{array}$ & $\begin{array}{r}1312261.9 \\
-604.52\end{array}$ & 0 & 0 & 0 & $\begin{array}{l}-1930.37571281 .32 \\
A X-102 \text { Inner }\end{array}$ \\
\hline 41 SQ & $\begin{array}{r}741424.32 \\
1371.60\end{array}$ & $\begin{array}{r}741424.32 \\
-1554.48\end{array}$ & $\begin{array}{r}2974452.1 \\
-1043.94\end{array}$ & 0 & 0 & 0 & $\begin{array}{l}-2205331147889.3 \\
\text { Upper Surface }\end{array}$ \\
\hline $42 \mathrm{SQ}$ & $\begin{array}{r}147102.93 \\
-1371.60\end{array}$ & $\begin{array}{r}1471 \\
15\end{array}$ & $\begin{array}{r}1312261.9 \\
-604.52\end{array}$ & 0 & 0 & 0 & $\begin{array}{l}-193037571281.32 \\
A X-103 \text { Inner }\end{array}$ \\
\hline & $\begin{array}{r}741424.32 \\
-1371.60\end{array}$ & $\begin{array}{r}74142 \\
155\end{array}$ & $\begin{array}{r}2974452.1 \\
-1043.94\end{array}$ & 0 & 0 & 0 & $\begin{array}{l}-2205331147889.3 \\
\text { Upper Surface }\end{array}$ \\
\hline & $\begin{array}{r}147102.93 \\
-1371.60\end{array}$ & $\begin{array}{r}147102 \\
-1554\end{array}$ & $\begin{array}{r}1312261.9 \\
-604.52\end{array}$ & 0 & 0 & 0 & $\begin{array}{l}-193037571281.32 \\
A X-104 \text { Inner }\end{array}$ \\
\hline & $\begin{array}{r}741424.32 \\
-1371.60\end{array}$ & $\begin{array}{r}741424.32 \\
-1554.48\end{array}$ & $\begin{array}{r}2974452.1 \\
-1043.94\end{array}$ & 0 & 0 & 0 & $\begin{array}{l}-2205331147889.3 \\
\text { Upper Surface }\end{array}$ \\
\hline & -137 & & -3657.60 & & 9 & & $\$$ Hole in $A X-1$ \\
\hline
\end{tabular}

$\mathrm{m} 1 \$$ Air at $80^{\circ} \mathrm{F}$ and $20.0 \%$ Relative Humidity

$$
\begin{array}{rlll}
1001.01 p & -0.00048 & \$ & \text { Hydrogen } \\
6012.01 p & -0.00014 & \$ & \text { Carbon } \\
7014.01 p & -0.75191 & \$ & \text { Nitrogen } \\
8016.01 p & -0.23464 & \$ & \text { 0xygen } \\
18040.01 p & -0.01282 & \$ \text { Argon }
\end{array}
$$

$\mathrm{m} 2 \$$ Hanford Soil with $0.10 \mathrm{~m} 7 / \mathrm{cc}$ Water

$1001.01 p \quad-0.00617 \$$ Hydrogen

8016.01p -0.47331 \$ 0xygen

$11023.01 \mathrm{p}-0.01678 \$$ Sodium

$12000.01 \mathrm{p}-0.02722$ \$ Magnesium

$13027.01 \mathrm{p}-0.06864$ \$ Aluminum

$14000.01 \mathrm{p}-0.22887$ \$ Silicon

$15031.01 \mathrm{p}-0.00222$ \$ Phosphorus

$19000.01 \mathrm{p} \quad-0.01068$ \& Potassium

$20000.01 p \quad-0.05969$ \$ Calcium

$22000.01 \mathrm{p}-0.01425$ \$ Titanium

$25055.01 \mathrm{p}-0.00151$ \$ Manganese

$26000.01 p-0.09064 \$$ Iron

m3 \$ Hanford Concrete

$\begin{array}{rrll}1001.01 p & -0.00310 & \$ \text { Hydrogen } \\ 8016.01 p & -0.44070 & \$ & \text { Oxygen } \\ 11023.01 p & -0.01820 & \$ \text { Sodium } \\ 12000.01 p & -0.03760 & \$ \text { Magnesium } \\ 13027.01 p & -0.06070 & \$ \text { Aluminum } \\ 14000.01 p & -0.21570 & \$ \text { Silicon } \\ 15031.01 p & -0.00090 & \$ \text { Phosphorus } \\ 16032.01 p & -0.00090 & \$ \text { Sulfur } \\ 20000.01 p & -0.13060 & \$ \text { Calcium } \\ 22000.01 p & -0.00490 & \$ \text { Titanium }\end{array}$




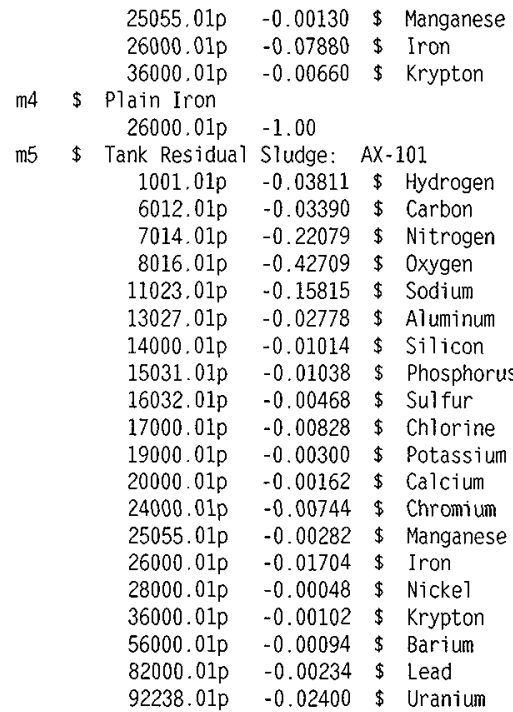

m6 \$ Tank Residual Sludge: AX-102

1001.01p -0.04722 \$ Hydrogen

6012.01p -0.01731 \$ Carbon

7014.01p -0.03693 \$ Nitrogen

8016.01p $-0.64925 \$$ 0xygen

$11023.01 \mathrm{p}-0.07560 \$$ Sodium

$13027.01 \mathrm{p} \quad-0.03093$ \$ Aluminum

$14000.01 p-0.02249$ \$ Silicon

$15031.01 p-0.00147$ \$ Phosphorus

$16032.01 \mathrm{p}-0.00209 \$$ Sulfur

$17000.01 \mathrm{p}-0.00075 \$$ Chlorine

$19000.01 p-0.00018 \$$ Potassium

$20000.01 \mathrm{p}-0.00506$ \$ Calcium

$24000.01 p \quad-0.00015 \$$ Chromium

$25055.01 \mathrm{p}-0.00762$ \& Manganese

$26000.01 \mathrm{p} \quad-0.09060 \$$ Iron

28000.01p $-0.00344 \$$ Nicke 1

$92238.01 \mathrm{p}-0.00890 \$$ Uranium

m7 \$ Tank Residual Sludge: AX-103 \& AX-104

$1001.01 \mathrm{p} \quad-0.04722 \$$ Hydrogen

$7014.01 \mathrm{p}-0.00213$ \& Nitrogen

$8016.01 \mathrm{p} \quad-0.62394 \$$ oxygen

$11023.01 p \quad-0.04262 \$$ Sodium

$12000.01 \mathrm{p}-0.00229 \$$ Magnesium

13027.01p $-0.03706 \$$ Aluminum

$14000.01 p \quad-0.03875 \$$ Silicon

$15031.01 p-0.00583 \$$ Phosphorus

$16032.01 p \quad-0.00719 \$$ Sulfur

$20000.01 p-0.01455 \$$ Calcium

$24000.01 p \quad-0.00174$ \$ Chromium

$25055.01 \mathrm{p}-0.00256 \$$ Manganese

$26000.01 p-0.16404 \$$ Iron 


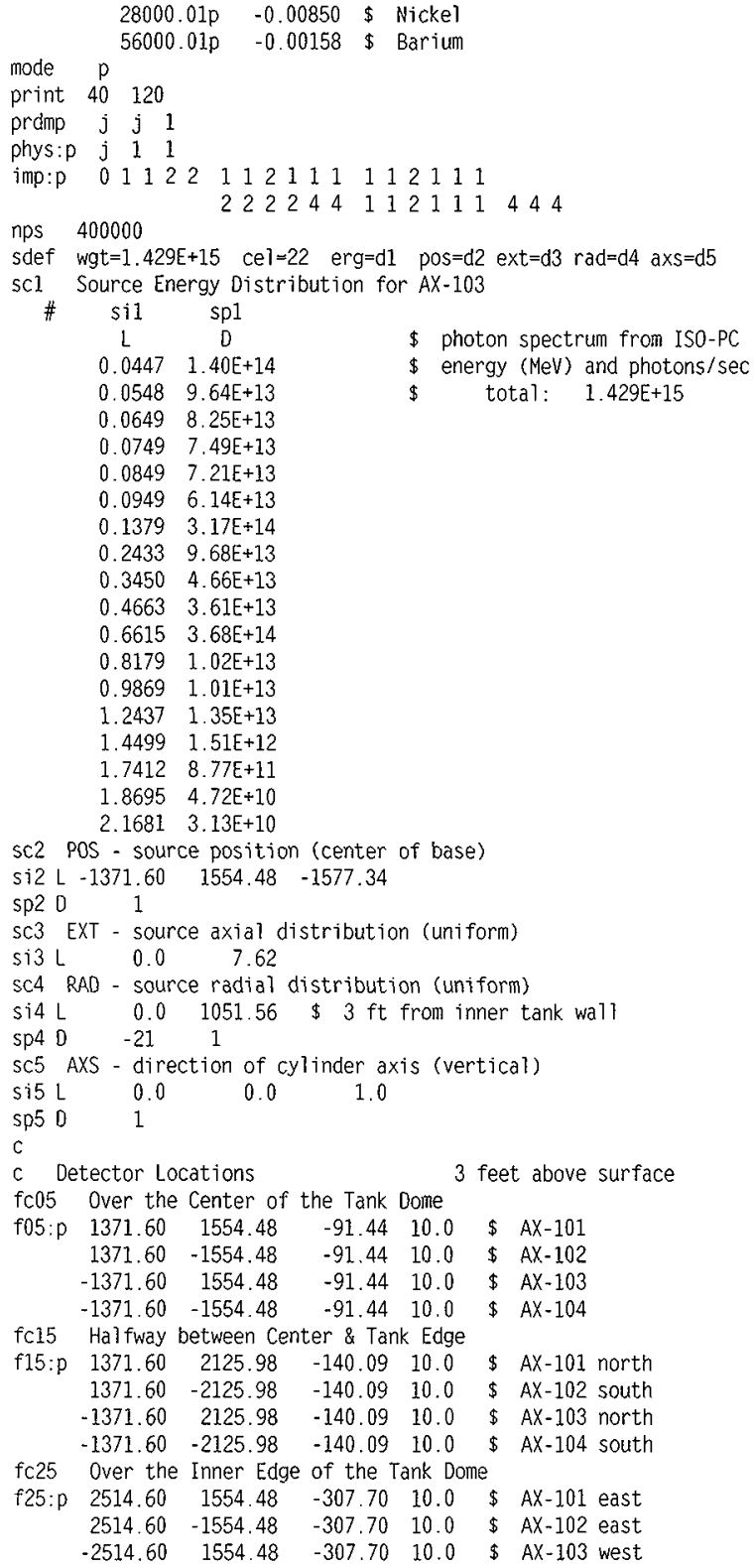




\begin{tabular}{|c|c|c|c|c|c|c|}
\hline & -2514.60 & -1554.48 & -307.70 & 10.0 & $\$$ & AX-104 west \\
\hline & \multicolumn{6}{|c|}{ N-S Line Between Tanks } \\
\hline \multirow{9}{*}{$f 35: p$} & 0.00 & 6868.00 & 91.44 & 10.0 & $\$$ & $100 \mathrm{ft} N$ of Excavation \\
\hline & 0.00 & 5344.00 & 91.44 & 10.0 & $\$$ & $50 \mathrm{ft} \mathrm{N}$ of Excavation \\
\hline & 0.00 & 3820.00 & 91.44 & 10.0 & $\$$ & $N$ Edge of Excavation \\
\hline & 0.00 & 1554.48 & -326.71 & 10.0 & $\$$ & Between AX-101 \& AX-103 \\
\hline & 0.00 & 0.00 & -326.71 & 10.0 & $\$$ & Center Point \\
\hline & 0.00 & -1554.48 & -326.71 & 10.0 & $\$$ & Between $A X-102 \& A X-104$ \\
\hline & 0.00 & -3820.00 & 91.44 & 10.0 & $\$$ & $S$ Edge of Excavation \\
\hline & 0.00 & -5344.00 & 91.44 & 10.0 & $\$$ & $50 \mathrm{ft} S$ of Excavation \\
\hline & 0.00 & -6868.00 & 91.44 & 10.0 & $\$$ & $100 \mathrm{ft} \mathrm{S}$ of Excavation \\
\hline$f c 45$ & E-W Line & Between $\mathrm{T}$ & nks & & & \\
\hline$f 45: p$ & 6685.12 & 0.00 & 91.44 & 10.0 & $\$$ & $100 \mathrm{ft} E$ of Excavation \\
\hline & 5161.12 & 0.00 & 91.44 & 10.0 & $\$$ & $50 \mathrm{ft} E$ of Excavation \\
\hline & 3637.12 & 0.00 & 91.44 & 10.0 & $\$$ & $E$ Edge of Excavation \\
\hline & 1371.60 & 0.00 & -326.71 & 10.0 & $\$$ & Between AX-101 \& AX-102 \\
\hline & -1371.60 & 0.00 & -326.71 & 10.0 & $\$$ & Between $A X-103 \& A X-104$ \\
\hline & -3637.12 & 0.00 & 91.44 & 10.0 & $\$$ & W Edge of Excavation \\
\hline & -5161.12 & 0.00 & 91.44 & 10.0 & $\$$ & $50 \mathrm{ft} W$ of Excava \\
\hline & -6685.12 & 0.00 & 91.44 & 10.0 & $\$$ & $100 \mathrm{ft}$ \\
\hline$f c 55$ & other Po & ints Near & e of $E$ & icavat & & \\
\hline$f 55: p$ & 3637.12 & 3820.00 & 91.44 & 10.0 & $\$$ & NE \\
\hline & 3637.12 & 1554.48 & & 10.0 & $\$$ & $A X-$ \\
\hline & 3637.12 & -1554.48 & 91.44 & 10.0 & $\$$ & $A X-$ \\
\hline & 3637.12 & -3820.00 & 91.44 & 10.0 & $\$$ & SE \\
\hline & -3637.12 & 3820.00 & 91.44 & 10.0 & $\$$ & $\mathrm{NW}$ \\
\hline & -3637.12 & 1554.48 & 91.44 & 10.0 & $\$$ & 3 west \\
\hline & -3637.12 & -1554.48 & 91.44 & 10.0 & $\$$ & 4 west \\
\hline & -3637.12 & -3820.00 & 91.44 & 10.0 & $\$$ & SW Corner \\
\hline C & ins for $\mathrm{Ph}$ & oton Talli & & & & \\
\hline eo & $0.03 \quad 0.05$ & 0.07 & $0 \quad 0.13$ & 0.16 & 0.20 & $\begin{array}{lll}0.25 & 0.30 & 0.40\end{array}$ \\
\hline & $0.50 \quad 0.70$ & 1.001. & 02.00 & 2.50 & & \\
\hline c & NSI / ANS - 6 . & $1-1991 \mathrm{f}$ & uence-to & dose, 1 & photon & $\mathrm{ns}\left(\mathrm{mrem} / \mathrm{hr} /\left(\mathrm{p} / \mathrm{cm}^{*} \star 2 / \mathrm{s}\right)\right.$ \\
\hline deo & $\log 0$. & 0.015 & 0.02 & 0.03 & 0.04 & 0.05 \\
\hline & & 0.08 & 0 . & 0.15 & 0.20 & 0.30 \\
\hline & & 0.50 & 0.60 & 0.80 & 1.0 & 1.5 \\
\hline & 2. & 3.0 & 4.0 & 5.0 & 6.0 & 8.0 \\
\hline dfo & $\log 2.2$ & $32 e-55.6$ & -58.5 & 5 & $184 \mathrm{e}-$ & $-4 \quad 1.314 e-4 \quad 1.382 e-4$ \\
\hline & & $40 e-41.62$ & $e-41.9$ & & & $-43.708 e-4 \quad 5.616 e-4$ \\
\hline & & $16 e-49.1$ & -41 & & & 32.246 \\
\hline & & -33.6 & -34 & & & $-36.012 e-37.488 e$ \\
\hline
\end{tabular}


Table 17. Single Tank Case -- Dome Intact, $\mathrm{AX}-101$ Source, $70.5 \mathrm{lb} / \mathrm{ft}^{3}$ Grout

\begin{tabular}{|c|c|c|c|c|c|c|c|}
\hline 1 & 0 & $(-12)$ & $: 1: 16)$ & & & $\$$ Outside world & U \\
\hline 2 & $2-1.8000$ & 12 & $-11-16$ & & & \$ Soil Under Tank & \\
\hline 3 & $2-1.8000$ & 11 & $-4-16$ & 15 & & $\$$ Soil Around Tank & \\
\hline 4 & $2-1.8000$ & 4 & $-3-16$ & 15 & & $\$$ Bottom of Excavation & 4096 \\
\hline 5 & $2-1.8000$ & 3 & $-2-16$ & $(17: 18)$ & & $\$$ Outside Surface Soil & 4096 \\
\hline 6 & $3-2.2580$ & 11 & $-10-15$ & & & \$ Conc Base - Bottom & 2 \\
\hline 7 & $3-2.2580$ & 10 & $-4 \quad 14$ & -15 & & $\$$ Conc Wall - Outer & 11 \\
\hline 8 & $3-2.2580$ & 10 & $-9-14$ & & & $\$$ Conc Base - Top & . \\
\hline 9 & $3-2.2580$ & 9 & $-4 \quad 13$ & -14 & & $\$$ Conc Wall - Inner & 32 \\
\hline 10 & $4-7.8600$ & 9 & $-8-13$ & & & $\$$ Bottom Iron Liner & \\
\hline 11 & $5-1.6350$ & 8 & $-7-13$ & & & $\$$ Waste - AX-101 & 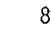 \\
\hline 12 & $3-2.2580$ & 7 & $-6-13$ & & & $\$$ Grout Layer 1 & 16 \\
\hline 13 & $3-2.2580$ & 6 & $-5-13$ & & & $\$$ Grout Layer 2 & 32 \\
\hline 14 & $1-0.0012$ & $\langle(5$ & $-4):(4-$ & -19)) & -13 & $\$$ Tank Air & 64 \\
\hline 15 & $3-2.2580$ & 4 & $-20(19:$ & 13) & & $\$$ Dome Inner Layer & 128 \\
\hline 16 & $3-2.2580$ & 4 & $-21 \quad 20$ & -15 & & $\$$ Dome Layer 2 & 256 \\
\hline 17 & $3-2.2580$ & 4 & $-22 \quad 21$ & -15 & & $\$$ Dome Layer 3 & 512 \\
\hline 18 & $3-2.2580$ & 4 & $\begin{array}{ll}-23 & 22\end{array}$ & -15 & & $\$$ Dome Layer 4 & 1024 \\
\hline 19 & $3-2.2580$ & 4 & $-24 \quad 23$ & -15 & & $\$$ Dome Layer 5 & 2048 \\
\hline 20 & $3-2.2580$ & 4 & $-25 \quad 24$ & -15 & & $\$$ Dome Outer Layer & 4096 \\
\hline 21 & $1-0.0012$ & 3 & $-2-16$ & $-17-18$ & $(15: 25)$ & $\$$ Air in Excavation & 8192 \\
\hline 22 & $1-0.0012$ & 2 & $-1-16$ & & & $\$$ Air Above Grade & 8192 \\
\hline
\end{tabular}

C Horizontal Planes

$1 \mathrm{PZ} 24384.0$ \$ Upper Boundary

$2 \mathrm{PZ} \quad 0.00 \$$ Ground Surface

$3 \mathrm{PZ}-418.15 \$$ Excavation Depth

$4 \mathrm{PZ}-604.52 \$$ Center of Inner Ellipsoid

$5 \mathrm{PZ}-1554.48 \$$ Grout/Debris Thickness

$6 \mathrm{PZ}-1562.10 \$$ Weighting Surface

$7 \mathrm{PZ}-1569.72 \$$ Upper Waste Surface

$8 \mathrm{PZ}-1577.34 \$$ Lower Waste Surface

$9 \mathrm{PZ}-1578.29 \$$ Iron/Concrete Boundary

$10 \mathrm{PZ}-1585.91$ \$ Weighting Surface

$11 \mathrm{PZ}-1623.06 \$$ Bottom of Tank

$12 \mathrm{PZ}-1805.94$ \$ Lower Boundary

c Vertical Cylinders

$13 \mathrm{CZ} \quad 1143.00 \$$ Inner Wall Surface

$14 \mathrm{CZ} \quad 1150.62$ \$ Weighting Surface

$15 \mathrm{CZ} \quad 1181.10$ \& Outer Wall Surface

$16 \mathrm{C} / 2 \quad 9144.00 \quad 0.00 \quad 18288.00 \$$ Outer Boundary

c Sloped Planes
17 ?
2.00
0.00
$-3.00$
$4531.04 \$$ East Side
$18 \mathrm{P}$
$0.00 \quad 2.00$
$-3.00$
$4531.04 \$$ North Side

C Ellipsoids for Tank Domes

\begin{tabular}{|c|c|c|c|c|c|c|c|}
\hline $\mathrm{cos}$ & & & & 0 & & & \\
\hline & 000 & 0.00 & & & & $\$$ & \\
\hline & 154001 & 154001.3 & 135626 & 0 & 0 & 0 & \\
\hline & & & & & & $\$$ & Laye \\
\hline & 163102 & $y$ & & 0 & 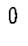 & 0 & -2 \\
\hline & 1 & 0 & 6 & 0 & 0 & $\$$ & -262671 \\
\hline & 37 & & & & & $\$$ & Layer 3 \\
\hline
\end{tabular}


HNF-3378-Rev. 0

$\begin{array}{rrrrllll} & 0.00 & 0.00 & -657.86 & & \$ & \text { Layer } 4 \\ 24 \text { SO } & 310839.7 & 310839.7 & 1965828.3 & 0 & 0 & 0 & -611057488998.92 \\ & 0.00 & 0.00 & -746.76 & & & \$ & \text { Layer } 5 \\ 25 \text { SO } & 741424.32 & 741424.32 & 2974452.1 & 0 & 0 & 0 & -2205331147889.3 \\ & 0.00 & 0.00 & -1043.94 & & & \$ \text { Outer Dome Surface }\end{array}$

$\mathrm{m} 1 \$$ Air at $80^{\circ} \mathrm{F}$ and $20.0 \%$ Relative Humidity

$\begin{array}{rrrl}1001.01 p & -0.00048 & \$ \text { Hydrogen } \\ 6012.01 p & -0.00014 & \$ \text { Carbon } \\ 7014.01 p & -0.75191 & \$ \text { Nitrogen } \\ 8016.01 p & -0.23464 & \$ \text { Oxygen } \\ 18040.01 p & -0.01282 & \$ \text { Argon }\end{array}$

m2

$\$$ Hanford Soil with $0.10 \mathrm{ml} / \mathrm{cc}$ Water

1001.01p $-0.00617 \$$ Hydrogen

8016.01p -0.47331 \$ Oxygen

$11023.01 p-0.01678 \$$ Sodium

$12000.01 p-0.02722$ \$ Magnesium

$13027.01 p \quad-0.06864 \$$ Aluminum

$14000.01 p \quad-0.22887 \$$ Silicon

$15031.01 \mathrm{p}-0.00222 \$$ Phosphorus

$19000.010-0.01068 \$$ Potassium

$20000.01 p-0.05969 \$$ Calcium

$22000.01 \mathrm{p}-0.01425 \$$ Titanium

$25055.01 p \quad-0.00151 \$$ Manganese

$26000.01 \mathrm{p}-0.09064$ \& Iron

m3 \$ Hanford Concrete

1001.010 $-0.00310 \$$ Hydrogen

$8016.01 p \quad-0.44070 \$$ oxygen

$11023.01 \mathrm{p}-0.01820 \$$ Sodium

$12000.01 \mathrm{p} \quad-0.03760 \$$ Magnesium

$13027.01 \mathrm{p} \quad-0.06070 \$$ Aluminum

$14000.01 p \quad-0.21570 \$$ Silicon

$15031.01 p-0.00090 \$$ Phosphorus

$16032.01 p-0.00090$ \$ Sulfur

$20000.01 \mathrm{p}-0.13060 \$$ Calcium

$22000.01 p \quad-0.00490 \$$ Titanium

$25055.01 \mathrm{p}-0.00130 \$$ Manganese

$26000.01 \mathrm{p}-0.07880$ \& Iron

$36000.010-0.00660 \$$ Krypton

m4 \$ Plain Iron

$26000.01 p \quad-1.00$

m5 \$ Tank Residual Sludge: AX-101

$\begin{array}{rlll}1001.01 p & -0.03811 & \$ & \text { Hydrogen } \\ 6012.01 p & -0.03390 & \$ & \text { Carbon } \\ 7014.01 p & -0.22079 & \$ & \text { Nitrogen } \\ 8016.01 p & -0.42709 & \$ & \text { Oxygen } \\ 11023.01 p & -0.15815 & \$ & \text { Sodium } \\ 13027.01 p & -0.02778 & \$ & \text { Aluminum } \\ 14000.01 p & -0.01014 & \$ \text { Silicon } \\ 15031.01 p & -0.01038 & \$ \text { Phosphorus } \\ 16032.01 p & -0.00468 & \$ & \text { Sulfur } \\ 17000.01 p & -0.00828 & \$ & \text { Chlorine } \\ 19000.01 p & -0.00300 & \$ & \text { Potassium } \\ 20000.01 p & -0.00162 & \$ \text { Calcium } \\ 24000.01 p & -0.00744 & \$ \text { Chromium } \\ 25055.01 p & -0.00282 & \$ \text { Manganese } \\ 26000.01 p & -0.01704 & \$ \text { Iron } \\ 28000.01 p & -0.00048 & \$ \text { Nickel }\end{array}$

A-Att2-14 
HNF-3378-Rev. 0

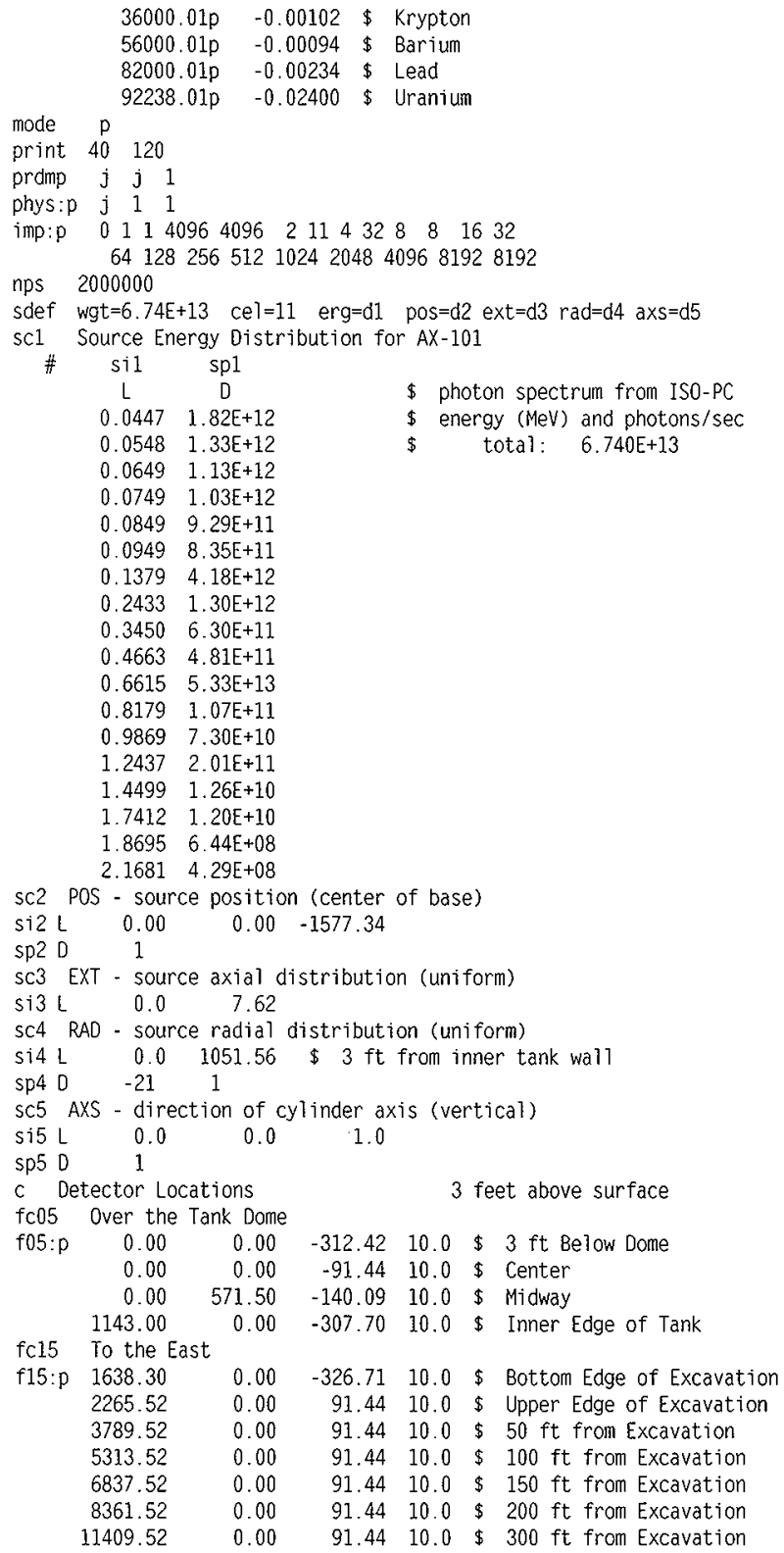


HNF-3378-Rev. 0

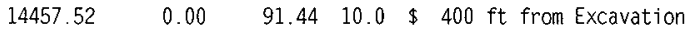

c Bins for Photon Tallies

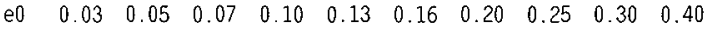
$0.50 \quad 0.70 \quad 1.00 \quad 1.50 \quad 2.00 \quad 2.50$

c ANSI/ANS-6.1.1-1991 fiuence-to-dose, photons $\left(\mathrm{mrem} / \mathrm{hr} /\left(\mathrm{p} / \mathrm{cm}{ }^{\star \star 2} / \mathrm{s}\right)\right.$

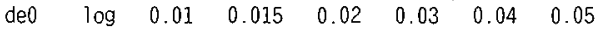

$\begin{array}{llllll}0.06 & 0.08 & 0.10 & 0.15 & 0.20 & 0.30\end{array}$

$\begin{array}{llllll}0.40 & 0.50 & 0.60 & 0.80 & 1.0 & 1.5\end{array}$

$\begin{array}{llllll}2.0 & 3.0 & 4.0 & 5.0 & 6.0 & 8.0\end{array}$

dfo $\quad \log 2.232 e-5 \quad 5.652 e-5 \quad 8.568 e-5 \quad 1.184 e-4 \quad 1.314 e-4 \quad 1.382 e-4$

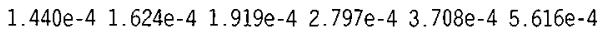

$7.416 \mathrm{e}-4 \quad 9.144 \mathrm{e}-4 \quad 1.076 \mathrm{e}-3 \quad 1.379 \mathrm{e}-3 \quad 1.656 \mathrm{e}-3 \quad 2.246 \mathrm{e}-3$

$2.758 \mathrm{e}-3 \quad 3.672 \mathrm{e}-3 \quad 4.500 \mathrm{e}-3 \quad 5.292 \mathrm{e}-3 \quad 6.012 \mathrm{e}-3 \quad 7.488 \mathrm{e}-3$ 
Table 18. Single Tank Case -- Dome Removed, AX-102 Source, $211.5 \mathrm{lb} / \mathrm{ft}^{3}$ Grout

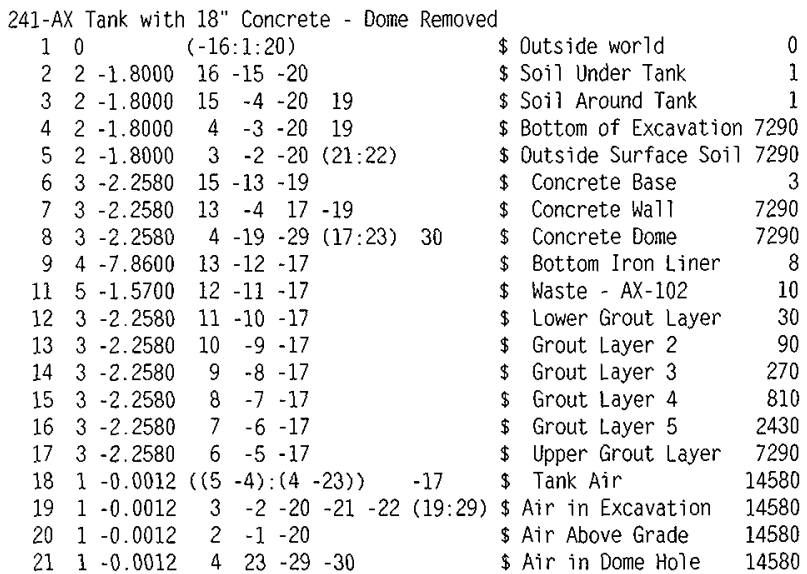

c Horizontal Planes
$1 \mathrm{PZ} 24384.0$ \$ Upper Boundary
$2 \mathrm{PZ} \quad 0.00 \$$ Ground Surface
$3 \mathrm{PZ}-418.15 \$$ Excavation Depth
$4 \mathrm{PZ}-604.52$ \$ Center of Inner Ellipsoid
$5 \mathrm{PZ}-1524.00 \$$ Grout/Debris Thickness
$6 \mathrm{PZ}-1531.62 \$$ Upper Weighting Surface
$7 \mathrm{PZ} \quad-1539.24 \$$ Middle Weighting Surface
$8 \mathrm{PZ}-1546.86 \$$ Middle Weighting Surface
$9 \mathrm{PZ}-1554.48 \$$ Middle Weighting Surface
$10 \mathrm{PZ}-1562.10 \$$ Lower Weighting Surface
$11 \mathrm{PZ}-1569.72$ \$ Upper Waste Surface
$12 \mathrm{PZ}-1577.34 \$$ Lower Waste Surface
$13 \mathrm{PZ}-1578.29 \$$ Iron/Concrete Boundary
$15 \mathrm{PZ}-1623.06$ \$ Bottom of Tank
$16 \mathrm{PZ}-1805.94 \$$ Lower Boundary
C Vertical Cylinders
$17 \mathrm{CZ} \quad 1143.00 \$$ Inner wall Surface
$19 \mathrm{CZ} \quad 1181.10$ \$ Outer Wall Surface
$20 \mathrm{C} / 2 \quad 9144.00 \quad 0.00 \quad 18288.00 \$$ Outer Boundary

c Sloped Planes
$21 \mathrm{P}$
2.00
$0.00 \quad-3.00$
4531.04 \$ East Side
$22 \mathrm{P}$
$0.00 \quad 2.00 \quad-3.00$
$4531.04 \$$ North Side

C Ellipsoids for Tank Domes

$\begin{array}{rrrrlllr}23 \mathrm{SO} & 147102.93 & 147102.93 & 1312261.9 & 0 & 0 & 0 & -193037571281.32 \\ & 0.00 & 0.00 & -604.52 & & & \$ & \text { Inner Dome Surface } \\ 29 \mathrm{SQ} & 741424.32 & 741424.32 & 2974452.1 & 0 & 0 & 0 & -2205331147889.3 \\ & 0.00 & 0.00 & -1043.94 & & & \$ & \text { Outer Dome Surface }\end{array}$

$\begin{array}{lllll}30 & \mathrm{KZ} & -3657.60 & 0.126879 & 1\end{array}$ \$ Hole in Dome

$\mathrm{ml} \$$ Air at $80^{\circ} \mathrm{F}$ and $20.0 \%$ Relative Humidity

$$
\begin{array}{llll}
1001.010 & -0.00048 & \$ \text { Hydrogen } \\
5012.01 p & -0.00014 & \$ \text { Carbon } \\
7014.010 & -0.75191 \$ \text { Nitrogen }
\end{array}
$$


HNF-3378-Rev. 0

$\begin{array}{ccc}8016.01 \mathrm{p} & -0.23464 & \$ \text { Oxygen } \\ \mathrm{m} 2 \text { 18040.01p } & -0.01282 & \$ \text { Argon } \\ \text { Hanford Soil } & \text { with } 0.10 \mathrm{ml} / \mathrm{cc} \text { Water } \\ 1001.01 \mathrm{p} & -0.00617 & \$ \text { Hydrogen } \\ 8016.01 \mathrm{p} & -0.47331 & \$ \text { Oxygen } \\ 11023.01 \mathrm{p} & -0.01678 & \$ \text { Sodium } \\ 12000.01 \mathrm{p} & -0.02722 & \$ \text { Magnesium } \\ 13027.01 \mathrm{p} & -0.06864 & \$ \text { Aluminum } \\ 14000.01 \mathrm{p} & -0.22887 & \$ \text { Silicon } \\ 15031.01 \mathrm{p} & -0.00222 & \$ \text { Phosphorus } \\ 19000.01 \mathrm{p} & -0.01068 & \$ \text { Potassium } \\ 20000.01 \mathrm{p} & -0.05969 & \$ \text { Calcium } \\ 22000.01 \mathrm{p} & -0.01425 & \$ \text { Titanium } \\ 25055.01 \mathrm{p} & -0.00151 & \$ \text { Manganese } \\ 26000.01 \mathrm{p} & -0.09064 & \$ \text { Iron }\end{array}$

$\mathrm{m} 3$

$\$$ Hanford Concrete

$\begin{array}{rrrl}1001.01 p & -0.00310 & \$ \text { Hydrogen } \\ 8016.01 p & -0.44070 & \$ \text { Oxygen } \\ 11023.01 p & -0.01820 & \$ \text { Sodium } \\ 12000.01 p & -0.03760 & \$ \text { Magnesium } \\ 13027.01 p & -0.06070 & \$ \text { Aluminum } \\ 14000.01 p & -0.21570 & \$ \text { Silicon } \\ 15031.01 p & -0.00090 & \$ \text { Phosphorus } \\ 16032.01 p & -0.00090 & \$ \text { Sulfur } \\ 20000.01 p & -0.13060 & \$ \text { Calcium } \\ 22000.01 p & -0.00490 & \$ \text { Titanium } \\ 25055.01 p & -0.00130 & \$ \text { Manganese } \\ 26000.01 p & -0.07880 & \$ \text { Iron } \\ 36000.01 p & -0.00660 & \$ \text { Krypton }\end{array}$

m4 \$ Plain Iron

$26000.01 p \quad-1.00$

m5 \$ Tank Residual Sludge: AX-102

1001.01p -0.04722 \$ Hydrogen

$6012.01 p-0.01731$ \$ Carbon

$7014.01 \mathrm{p}-0.03693$ \& Nitrogen

$8016.01 \mathrm{p}-0.64925 \$$ 0xygen

$11023.01 \mathrm{p} \quad-0.07560 \$$ Sodium

$13027.01 \mathrm{p}-0.03093 \$$ Aluminum

$14000.01 p-0.02249 \$$ Silicon

$15031.01 \mathrm{p}-0.00147$ \$ Phosphorus

$16032.01 p-0.00209 \$$ Sulfur

$17000.01 p-0.00075 \$$ Chlorine

$19000.01 p-0.00018$ \$ Potassium

$20000.01 \mathrm{p} \quad-0.00506$ \& Calcium

24000.01p -0.00015 \& Chromium

$25055.01 \mathrm{p}-0.00762 \$$ Manganese

$26000.01 p-0.09060 \$$ Iron

$28000.01 p-0.00344 \$$ Nickel

$92238.01 p \quad-0.00890 \quad \$$ Uranium

mode $p$

print 40120

prdmp j j 1

phys:p $\quad j \quad 1 \quad 1$

imp:p $011172907290372907290810 \quad 30 \quad 902708102430729014580 \quad 3 \mathrm{r}$

nps 600000

sdef $w g t=5.07 E+14 \quad c e 1=11$ erg $=d 1 \quad$ pos $=d 2$ ext $=\mathrm{d} 3 \quad$ rad $=\mathrm{d} 4 \quad$ axs $=\mathrm{d} 5$

sc1 Source Energy Distribution for AX-102

\# sil spl 


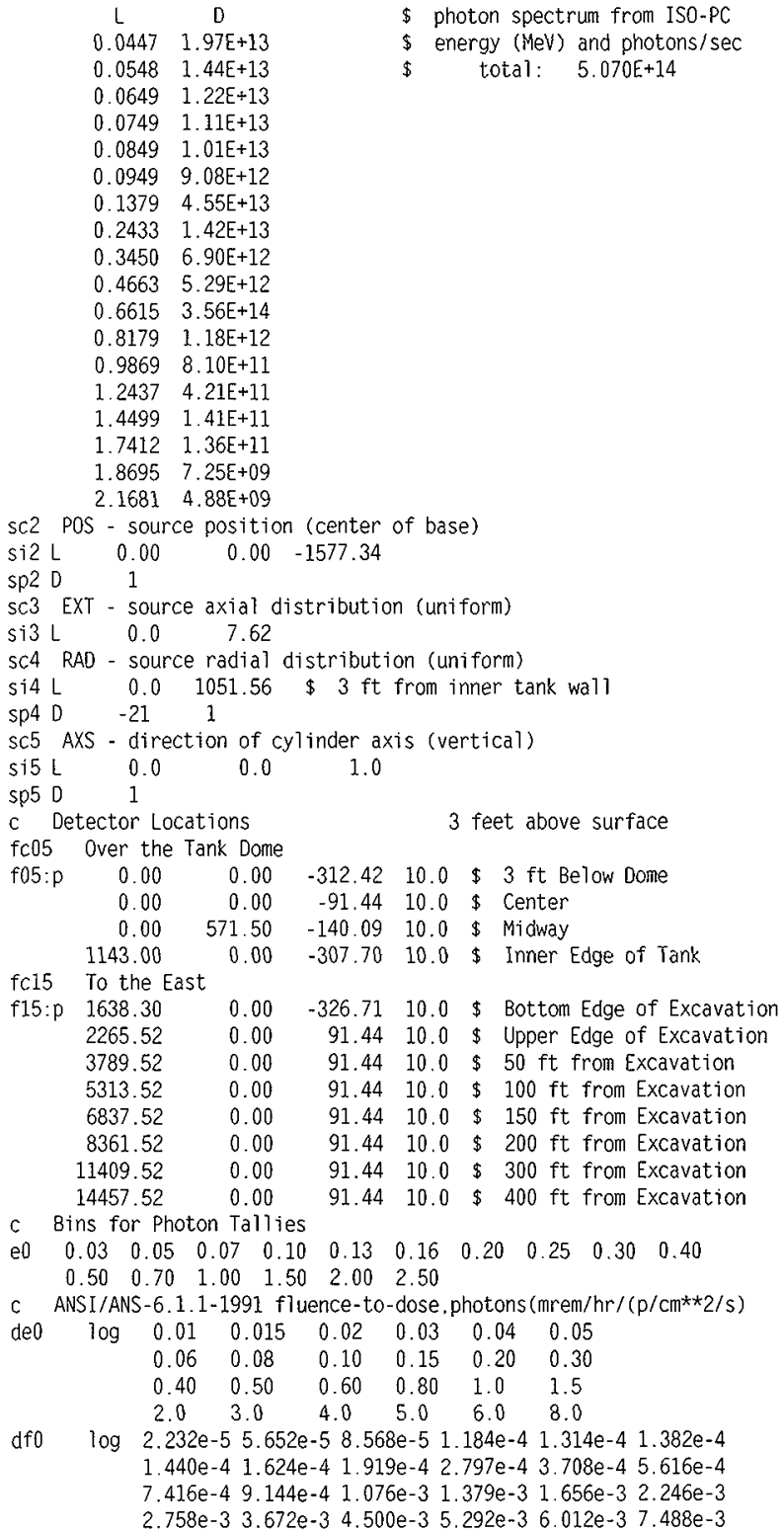

df0 $\quad \log 2.232 e-5 \quad 5.652 e-5 \quad 8.568 \mathrm{e}-5 \quad 1.184 \mathrm{e}-4 \quad 1.314 \mathrm{e}-4 \quad 1.382 \mathrm{e}-4$ $1.440 \mathrm{e}-4 \quad 1.624 \mathrm{e}-4 \quad 1.919 \mathrm{e}-4 \quad 2.797 \mathrm{e}-4 \quad 3.708 \mathrm{e}-4 \quad 5.616 \mathrm{e}-4$ $7.416 \mathrm{e}-4 \quad 9.144 \mathrm{e}-4 \quad 1.076 \mathrm{e}-3 \quad 1.379 \mathrm{e}-3 \quad 1.656 \mathrm{e}-3 \quad 2.246 \mathrm{e}-3$ $2.758 \mathrm{e}-3 \quad 3.672 \mathrm{e}-3 \quad 4.500 \mathrm{e}-3 \quad 5.292 \mathrm{e}-3 \quad 6.012 \mathrm{e}-3 \quad 7.488 \mathrm{e}-3$ 
HNF-3378-Rev. 0

\section{ATTACHMENT 3}

MCNP RESULTS SHOWING RELATIVE ERRORS REPORTED 
HNF-3378-Rev. 0

Table 19. MCNP Dose Rates 3 Feet Above Surfaces With Soil Removed from Tank Domes -- 99 Percent Retrieval

\begin{tabular}{|c|c|c|c|c|c|c|c|c|c|c|}
\hline Detector Location & $\begin{array}{l}\text { AX-101 } \\
\mathrm{mrem} / \mathrm{h}\end{array}$ & $\begin{array}{c}\text { Source } \\
\% \text { RE }\end{array}$ & $\begin{array}{l}\mathrm{AX}-102 \\
\mathrm{mrem} / \mathrm{h}\end{array}$ & $\begin{array}{c}\text { Source } \\
\% \text { RE }\end{array}$ & $\begin{array}{l}\text { Ax-103 } \\
\text { mrem/h }\end{array}$ & $\begin{array}{c}\text { Source } \\
\% \text { RE }\end{array}$ & $\begin{array}{l}\text { AX-104 } \\
\text { mrem/h }\end{array}$ & $\begin{array}{c}\text { Source } \\
\% \text { RE }\end{array}$ & $\begin{array}{r}\text { Total } \\
\text { mrem/h }\end{array}$ & Check \\
\hline $\begin{array}{l}\text { Center of the Dome } \\
A X-101 \\
A X-102 \\
A X-103 \\
A X-104\end{array}$ & $\begin{array}{l}8.45 \\
0.03 \\
0.04 \\
0.02\end{array}$ & $\begin{array}{l}5.6 \\
3.8 \\
2.7 \\
4.0\end{array}$ & $\begin{array}{r}0.19 \\
62.42 \\
0.11 \\
0.23\end{array}$ & $\begin{array}{l}2.6 \\
5.7 \\
4.3 \\
2.6\end{array}$ & $\begin{array}{r}0.34 \\
0.16 \\
95.83 \\
0.26\end{array}$ & $\begin{array}{l}3.5 \\
4.3 \\
9.2 \\
3.6\end{array}$ & $\begin{array}{r}0.16 \\
0.33 \\
0.25 \\
99.28\end{array}$ & $\begin{array}{r}6.5 \\
4.2 \\
2.7 \\
10.6\end{array}$ & $\begin{array}{r}9.13 \\
62.93 \\
96.23 \\
99.79\end{array}$ & $\begin{array}{r}2.2 \% \\
0.6 \% \\
-3.5 \% \\
3.8 \%\end{array}$ \\
\hline $\begin{array}{l}\text { Midway to Inner Edge of } \\
A X-101 \text { north } \\
A X-102 \text { south } \\
A X-103 \text { north } \\
A X-104 \text { south }\end{array}$ & $\begin{array}{l}\text { the Dome } \\
6.72 \\
0.02 \\
0.03 \\
0.01\end{array}$ & $\begin{array}{r}5.8 \\
3.3 \\
4.4 \\
9.0 \\
\end{array}$ & $\begin{array}{r}0.14 \\
44.24 \\
0.09 \\
0.20\end{array}$ & $\begin{array}{l}6.0 \\
7.1 \\
4.6 \\
2.3\end{array}$ & $\begin{array}{r}0.31 \\
0.14 \\
61.30 \\
0.19\end{array}$ & $\begin{array}{r}6.9 \\
11.6 \\
8.0 \\
5.6\end{array}$ & $\begin{array}{r}0.13 \\
0.30 \\
0.18 \\
69.70\end{array}$ & $\begin{array}{l}4.3 \\
3.7 \\
6.1 \\
8.4\end{array}$ & $\begin{array}{r}7.29 \\
44.70 \\
61.60 \\
70.11\end{array}$ & $\begin{array}{r}5.8 \% \\
12.0 \% \\
-12.8 \% \\
7.5 \%\end{array}$ \\
\hline $\begin{array}{l}\text { Inner Edge of the Dome } \\
A X-101 \text { east } \\
A X-102 \text { east } \\
A X-103 \text { west } \\
A X-104 \text { west }\end{array}$ & $\begin{array}{l}0.10 \\
0.02 \\
0.01 \\
0.01\end{array}$ & $\begin{array}{r}5.5 \\
4.9 \\
10.5 \\
3.3\end{array}$ & $\begin{array}{l}0.15 \\
0.72 \\
0.06 \\
0.09\end{array}$ & $\begin{array}{l}6.8 \\
5.6 \\
4.3 \\
4.7\end{array}$ & $\begin{array}{l}0.11 \\
0.09 \\
1.12 \\
0.19\end{array}$ & $\begin{array}{l}3.5 \\
5.4 \\
6.9 \\
4.2\end{array}$ & $\begin{array}{l}0.09 \\
0.11 \\
0.18 \\
1.54\end{array}$ & $\begin{array}{r}7.3 \\
5.2 \\
3.1 \\
15.6\end{array}$ & $\begin{array}{l}0.45 \\
0.94 \\
1.37 \\
1.82\end{array}$ & $\begin{array}{r}-7.4 \% \\
-4.9 \% \\
-31.6 \% \\
3.1 \%\end{array}$ \\
\hline $\begin{array}{l}\text { North-South Line Between } \\
100 \mathrm{ft} N \text { of Excavation } \\
50 \mathrm{ft} \mathrm{N} \text { of Excavation } \\
\mathrm{N} \text { Edge of Excavation } \\
\text { Between AX-101 \& AX-103 } \\
\text { Center Point } \\
\text { Between AX-102 \& AX-104 } \\
\mathrm{S} \text { Edge of Excavation } \\
50 \mathrm{ft} S \text { of Excavation } \\
100 \mathrm{ft} S \text { of Excavation }\end{array}$ & $\begin{array}{r}\text { Tanks } \\
0.01 \\
0.02 \\
0.05 \\
0.07 \\
0.04 \\
0.02 \\
0.01 \\
0.01 \\
0.00 \\
\end{array}$ & $\begin{array}{r}34.5 \\
6.5 \\
3.5 \\
3.3 \\
3.1 \\
4.1 \\
4.4 \\
5.7 \\
4.5 \\
\end{array}$ & $\begin{array}{l}0.03 \\
0.04 \\
0.08 \\
0.14 \\
0.29 \\
0.46 \\
0.33 \\
0.10 \\
0.06\end{array}$ & $\begin{array}{l}4.3 \\
2.9 \\
3.7 \\
5.0 \\
3.4 \\
4.4 \\
2.9 \\
6.7 \\
3.0\end{array}$ & $\begin{array}{l}0.09 \\
0.13 \\
0.45 \\
0.65 \\
0.36 \\
0.18 \\
0.12 \\
0.09 \\
0.04\end{array}$ & $\begin{array}{r}4.5 \\
3.1 \\
2.7 \\
4.2 \\
3.2 \\
3.4 \\
9.2 \\
25.8 \\
6.1\end{array}$ & $\begin{array}{l}0.04 \\
0.07 \\
0.10 \\
0.19 \\
0.37 \\
0.64 \\
0.49 \\
0.14 \\
0.09\end{array}$ & $\begin{array}{r}4.9 \\
17.4 \\
3.0 \\
6.2 \\
4.5 \\
4.7 \\
4.6 \\
3.9 \\
6.1 \\
\end{array}$ & $\begin{array}{l}0.16 \\
0.26 \\
0.67 \\
1.04 \\
1.06 \\
1.30 \\
0.95 \\
0.34 \\
0.19\end{array}$ & $\begin{array}{r}-1.3 \% \\
-1.7 \% \\
-8.2 \% \\
1.6 \% \\
-2.0 \% \\
-3.3 \% \\
14.1 \% \\
24.6 \% \\
10.0 \%\end{array}$ \\
\hline $\begin{array}{l}\text { East-West Line Between T } \\
100 \mathrm{ft} \text { of Excavation } \\
50 \mathrm{ft} E \text { of Excavation } \\
E \text { Edge of Excavation } \\
\text { Between } A X-101 \text { \& } A X-102 \\
\text { Between } A X-103 \& A X-104 \\
W \text { Edge of Excavation } \\
50 \mathrm{ft} W \text { of Excavation } \\
100 \mathrm{ft} W \text { of Excavation }\end{array}$ & $\begin{array}{c}\text { anks } \\
0.01 \\
0.01 \\
0.05 \\
0.05 \\
0.02 \\
0.01 \\
0.01 \\
0.00\end{array}$ & $\begin{array}{r}9.5 \\
5.2 \\
3.2 \\
2.7 \\
4.7 \\
4.3 \\
15.9 \\
4.1\end{array}$ & $\begin{array}{l}0.06 \\
0.10 \\
0.30 \\
0.39 \\
0.16 \\
0.09 \\
0.05 \\
0.03\end{array}$ & $\begin{array}{l}5.4 \\
3.7 \\
2.7 \\
3.0 \\
5.5 \\
4.4 \\
7.3 \\
5.1\end{array}$ & $\begin{array}{l}0.04 \\
0.08 \\
0.12 \\
0.20 \\
0.56 \\
0.43 \\
0.13 \\
0.09\end{array}$ & $\begin{array}{r}6.0 \\
12.3 \\
4.0 \\
3.6 \\
4.9 \\
3.8 \\
3.4 \\
12.6\end{array}$ & $\begin{array}{l}0.04 \\
0.08 \\
0.13 \\
0.19 \\
0.52 \\
0.45 \\
0.13 \\
0.08\end{array}$ & $\begin{array}{r}4.4 \\
16.5 \\
7.5 \\
3.2 \\
3.6 \\
7.1 \\
4.3 \\
3.0\end{array}$ & $\begin{array}{l}0.15 \\
0.28 \\
0.59 \\
0.84 \\
1.27 \\
0.98 \\
0.32 \\
0.20\end{array}$ & $\begin{array}{r}6.1 \% \\
0.9 \% \\
-9.6 \% \\
4.7 \% \\
6.3 \% \\
-4.3 \% \\
-0.2 \% \\
14.1 \%\end{array}$ \\
\hline
\end{tabular}


HNF-3378-Rev, 0

Table 19. MCNP Dose Rates 3 Feet Above Surfaces With Soil Removed from Tank Domes -- 99 Percent Retrieval (cont'd)

\begin{tabular}{|c|c|c|c|c|c|c|c|c|c|c|}
\hline Detector Location & $\begin{array}{l}\mathrm{AX}-101 \\
\text { mrem/h }\end{array}$ & $\begin{array}{c}\text { Source } \\
\% \text { RE }\end{array}$ & $\begin{array}{l}\text { AX-102 } \\
\text { mrem/h }\end{array}$ & $\begin{array}{c}\text { Source } \\
\% \text { RE }\end{array}$ & $\begin{array}{l}\text { AX-103 } \\
\text { mrem/h }\end{array}$ & $\begin{array}{c}\text { Source } \\
\% \text { RE }\end{array}$ & $\begin{array}{l}\mathrm{Ax}-104 \\
\mathrm{mrem} / \mathrm{h}\end{array}$ & $\begin{array}{c}\text { Source } \\
\% \text { RE }\end{array}$ & $\begin{array}{r}\text { Total } \\
\text { mrem/h }\end{array}$ & Check \\
\hline \multicolumn{11}{|c|}{ Other Points Near Excavation } \\
\hline $\begin{array}{l}\text { NE Corner } \\
\text { AX - 101 east }\end{array}$ & 0.03 & 4.7 & 0.08 & $\begin{array}{r}16.4 \\
46\end{array}$ & 0.10 & 2.8 & 0.07 & 13.4 & 0.29 & $1.7 \%$ \\
\hline$A X-102$ east & 0.02 & 3.1 & 0.47 & $\begin{array}{l}4.0 \\
2.5\end{array}$ & 0.12 & 17.7 & 0.12 & $\begin{array}{l}5.5 \\
3.2\end{array}$ & $\begin{array}{l}0.44 \\
0.74\end{array}$ & $\begin{array}{l}-1.4 \% \\
28.5 \%\end{array}$ \\
\hline SE Corner & 0.01 & 4.2 & 0.21 & 3.6 & 0.06 & 12.6 & 0.10 & 3.1 & 0.39 & $-13.6 \%$ \\
\hline NW Corner & 0.01 & 4.7 & 0.04 & 5.4 & 0.32 & 4.6 & 0.09 & 4.8 & 0.47 & $5.4 \%$ \\
\hline$A X-103$ west & 0.02 & 11.3 & 0.07 & 7.4 & 0.73 & 5.4 & 0.20 & 3.6 & 1.02 & $1.2 \%$ \\
\hline AX-104 west & 0.01 & 5.4 & 0.09 & 4.8 & 0.21 & 4.4 & 0.72 & 4.7 & 1.03 & $1.3 \%$ \\
\hline SW Corner & 0.01 & 8.1 & 0.08 & 3.4 & 0.09 & 3.8 & 0.30 & 3.4 & 0.47 & $-2.7 \%$ \\
\hline
\end{tabular}

The column labeled "Check" compares the AX-103 dose rate with the mirror image dose rate location for AX-104. Since the sources are the same, the dose rates at mirror image locations should be the same. The dose rates shown above were also listed in Table 7 . 
HNF-3378-Rev. 0

Table 20. MCNP Dose Rates 3 Feet Above Surfaces With a Tank Dome Removed -- 99 Percent Retrieval

\begin{tabular}{|c|c|c|c|c|c|c|c|c|c|c|}
\hline Detector Location & $\begin{array}{l}A X-101 \\
\text { mrem/h }\end{array}$ & $\begin{array}{l}\text { Source } \\
\% R E\end{array}$ & $\begin{array}{l}\mathrm{AX}-102 \\
\mathrm{mrem} / \mathrm{h}\end{array}$ & $\begin{array}{c}\text { Source } \\
\% R E\end{array}$ & $\begin{array}{l}\mathrm{AX}-103 \\
\mathrm{mrem} / \mathrm{h}\end{array}$ & $\begin{array}{c}\text { Source } \\
\% \mathrm{RE}\end{array}$ & $\begin{array}{l}\mathrm{AX}-104 \\
\mathrm{mrem} / \mathrm{h}\end{array}$ & $\begin{array}{c}\text { Source } \\
\% R E\end{array}$ & $\begin{array}{c}\text { Total } \\
\mathrm{mrem} / \mathrm{h}\end{array}$ & Check \\
\hline $\begin{array}{l}\text { Center of the Dome } \\
\text { AX-101 } \\
A X-102 \\
A X-103 \\
A X-104\end{array}$ & $\begin{array}{r}1.943 \\
14 \\
18 \\
8\end{array}$ & $\begin{array}{l}0.5 \\
4.7 \\
3.6 \\
3.0\end{array}$ & $\begin{array}{r}103 \\
13.750 \\
63 \\
148\end{array}$ & $\begin{array}{r}2.5 \\
0.3 \\
4.4 \\
14.0\end{array}$ & $\begin{array}{r}236 \\
111 \\
20,660 \\
183\end{array}$ & $\begin{array}{l}4.8 \\
4.9 \\
0.7 \\
5.4\end{array}$ & $\begin{array}{r}115 \\
232 \\
178 \\
20,660\end{array}$ & $\begin{array}{l}7.7 \\
4.7 \\
4.6 \\
0.5\end{array}$ & $\begin{array}{r}2.397 \\
14.107 \\
20.919 \\
20.999\end{array}$ & $\begin{array}{r}1.8 \% \\
-3.2 \% \\
0.0 \% \\
2.6 \%\end{array}$ \\
\hline $\begin{array}{l}\text { Midway to Inner Edge of } \\
\text { AX-101 north } \\
A X-102 \text { south } \\
A X-103 \text { north } \\
A X-104 \text { south }\end{array}$ & $\begin{array}{r}\text { the Dome } \\
1.867 \\
9 \\
18 \\
6\end{array}$ & $\begin{array}{r}0.6 \\
3.2 \\
11.2 \\
3.3\end{array}$ & $\begin{array}{r}68 \\
13,300 \\
48 \\
123\end{array}$ & $\begin{array}{l}4.2 \\
0.4 \\
2.4 \\
4.3\end{array}$ & $\begin{array}{r}208 \\
91 \\
19,890 \\
125\end{array}$ & $\begin{array}{l}3.6 \\
6.6 \\
0.6 \\
9.1\end{array}$ & $\begin{array}{r}99 \\
220 \\
145 \\
19,610\end{array}$ & $\begin{array}{r}7.1 \\
5.1 \\
13.6 \\
0.4\end{array}$ & $\begin{array}{l}2,241 \\
13,620 \\
20,101 \\
19,864\end{array}$ & $\begin{array}{r}-5.8 \% \\
-7.8 \% \\
1.4 \% \\
-14.6 \%\end{array}$ \\
\hline $\begin{array}{l}\text { Inner Edge of the Dome } \\
\text { AX-101 east } \\
\text { AX-102 east } \\
\text { AX-103 west } \\
\text { AX-104 west }\end{array}$ & $\begin{array}{r}1,543 \\
10 \\
7 \\
5\end{array}$ & $\begin{array}{l}0.8 \\
4.6 \\
9.4 \\
4.8\end{array}$ & $\begin{array}{r}74 \\
11.140 \\
34 \\
51\end{array}$ & $\begin{array}{l}3.1 \\
1.5 \\
2.9 \\
7.8\end{array}$ & $\begin{array}{r}93 \\
67 \\
15.950 \\
140\end{array}$ & $\begin{array}{l}5.8 \\
9.6 \\
0.5 \\
5.6\end{array}$ & $\begin{array}{r}61 \\
84 \\
130 \\
16,020\end{array}$ & $\begin{array}{l}3.0 \\
3.3 \\
3.3 \\
0.6\end{array}$ & $\begin{array}{r}1,771 \\
11,301 \\
16.122 \\
16,215\end{array}$ & $\begin{array}{r}10.2 \% \\
9.5 \% \\
-0.4 \% \\
7.0 \%\end{array}$ \\
\hline $\begin{array}{l}\text { North-South Line Between } \\
100 \mathrm{ft} N \text { of Excavation } \\
50 \mathrm{ft} N \text { of Excavation } \\
\mathrm{N} \text { Edge of Excavation } \\
\text { Between AX-101 \& AX-103 } \\
\text { Center Point } \\
\text { Between AX-102 \& AX-104 } \\
\text { S Edge of Excavation } \\
50 \mathrm{ft} S \text { of Excavation } \\
100 \mathrm{ft} S \text { of Excavation } \\
\end{array}$ & $\begin{array}{r}\text { Tanks } \\
5 \\
8 \\
24 \\
67 \\
22 \\
11 \\
6 \\
4 \\
2 \\
\end{array}$ & $\begin{array}{r}9.9 \\
4.9 \\
3.9 \\
3.6 \\
3.6 \\
12.7 \\
9.3 \\
18.8 \\
4.9 \\
\end{array}$ & $\begin{array}{r}16 \\
25 \\
40 \\
72 \\
164 \\
475 \\
172 \\
60 \\
33 \\
\end{array}$ & $\begin{array}{l}4.0 \\
5.2 \\
2.7 \\
4.2 \\
4.4 \\
2.6 \\
2.3 \\
4.4 \\
2.2\end{array}$ & $\begin{array}{r}60 \\
93 \\
293 \\
785 \\
310 \\
131 \\
80 \\
54 \\
26 \\
\end{array}$ & $\begin{array}{r}4.1 \\
2.3 \\
3.7 \\
2.4 \\
9.5 \\
4.6 \\
12.9 \\
15.3 \\
3.5 \\
\end{array}$ & $\begin{array}{r}35 \\
45 \\
70 \\
133 \\
263 \\
832 \\
304 \\
101 \\
68\end{array}$ & $\begin{array}{r}15.5 \\
7.3 \\
5.0 \\
4.5 \\
2.1 \\
3.7 \\
3.1 \\
4.3 \\
7.6\end{array}$ & $\begin{array}{r}116 \\
171 \\
427 \\
1.057 \\
759 \\
1.449 \\
563 \\
219 \\
128\end{array}$ & $\begin{array}{r}-12.1 \% \\
-8.6 \% \\
-3.7 \% \\
-5.7 \% \\
16.4 \% \\
-1.4 \% \\
14.1 \% \\
17.4 \% \\
-29.8 \%\end{array}$ \\
\hline $\begin{array}{l}\text { East-West Line Between } T \\
100 \mathrm{ft} \text { E of Excavation } \\
50 \mathrm{ft} E \text { of Excavation } \\
\text { E Edge of Excavation } \\
\text { Between AX-101 \& AX-102 } \\
\text { Between AX-103 \& AX-104 } \\
W \text { Edge of Excavation } \\
50 \mathrm{ft} W \text { of Excavation } \\
100 \mathrm{ft} W \text { of Excavation }\end{array}$ & $\begin{array}{r}\text { anks } \\
5 \\
8 \\
23 \\
40 \\
11 \\
7 \\
4 \\
3\end{array}$ & $\begin{array}{l}6.2 \\
5.9 \\
6.4 \\
4.0 \\
3.4 \\
7.5 \\
6.0 \\
7.0\end{array}$ & $\begin{array}{r}44 \\
63 \\
182 \\
289 \\
85 \\
45 \\
28 \\
19\end{array}$ & $\begin{array}{r}27.3 \\
6.8 \\
7.2 \\
3.0 \\
4.0 \\
4.4 \\
11.3 \\
9.2\end{array}$ & $\begin{array}{r}34 \\
48 \\
80 \\
144 \\
519 \\
275 \\
93 \\
59\end{array}$ & $\begin{array}{r}12.8 \\
6.5 \\
5.3 \\
3.3 \\
3.0 \\
3.6 \\
2.8 \\
4.6\end{array}$ & $\begin{array}{r}30 \\
42 \\
83 \\
142 \\
507 \\
274 \\
103 \\
57\end{array}$ & $\begin{array}{l}7.9 \\
3.1 \\
7.2 \\
4.0 \\
2.9 \\
4.0 \\
5.1 \\
2.9\end{array}$ & $\begin{array}{r}113 \\
161 \\
368 \\
615 \\
1,121 \\
601 \\
226 \\
137\end{array}$ & $\begin{array}{r}13.7 \% \\
11.3 \% \\
-3.9 \% \\
1.4 \% \\
2.3 \% \\
0.3 \% \\
-10.0 \% \\
2.1 \%\end{array}$ \\
\hline
\end{tabular}




\section{HNF-3378-Rev. 0}

Table 20. MCNP Dose Rates 3 Feet Above Surfaces With a Tank Dome Removed -- 99 Percent Retrieval (cont'd)

\begin{tabular}{|c|c|c|c|c|c|c|c|c|c|c|}
\hline Detector Location & $\begin{array}{l}\mathrm{Ax}-101 \\
\mathrm{mrem} / \mathrm{h}\end{array}$ & $\begin{array}{c}\text { Source } \\
\% \text { RE }\end{array}$ & $\begin{array}{l}\text { Ax-102 } \\
\mathrm{mrem} / \mathrm{h}\end{array}$ & $\begin{array}{c}\text { Source } \\
\% \text { RE }\end{array}$ & $\begin{array}{l}\text { AX-103 } \\
\text { mrem/h }\end{array}$ & $\begin{array}{c}\text { Source } \\
\% \text { RE }\end{array}$ & $\begin{array}{l}\mathrm{AX}-104 \\
\mathrm{mrem} / \mathrm{h}\end{array}$ & $\begin{array}{c}\text { Source } \\
\% \text { RE }\end{array}$ & $\begin{array}{r}\text { Total } \\
\text { mrem/h }\end{array}$ & Check \\
\hline \multicolumn{11}{|c|}{ 0ther Points Near Excavation } \\
\hline NE Corner & 17 & 8.7 & 38 & 5.7 & 69 & 5.6 & 44 & 5.2 & 168 & $3.4 \%$ \\
\hline AX-101 east & 35 & 3.0 & 81 & 4.4 & 87 & 5.9 & 64 & 9.4 & 267 & $-5.9 \%$ \\
\hline$A X-102$ east & 11 & 4.5 & 249 & 1.7 & 69 & 11.8 & 92 & 9.9 & 422 & $6.6 \%$ \\
\hline SE Corner & 5 & 3.2 & 119 & 6.3 & 38 & 3.4 & 67 & 2.9 & 229 & $-13.4 \%$ \\
\hline NW Corner & 6 & 9.5 & 27 & 11.8 & 213 & 7.2 & 63 & 4.7 & 310 & $10.2 \%$ \\
\hline$A X-103$ west & 7 & 6.6 & 37 & 5.3 & 430 & 3.8 & 142 & 6.7 & 616 & $-2.5 \%$ \\
\hline$A X-104$ west & 5 & 2.6 & 47 & 3.5 & 133 & 2.5 & 440 & 3.6 & 625 & $-6.5 \%$ \\
\hline SW Corner & 3 & 10.6 & 40 & 2.6 & 63 & 5.0 & 193 & 4.9 & 299 & $-0.6 \%$ \\
\hline
\end{tabular}

The column labeled "Check" compares the AX-103 dose rate with the mirror image dose rate location for Ax-104. Since the sources are the same, the dose rates at mirror image locations should be the same. The dose rates shown above are strictly for the source identified in the column heading. The dose rates from residual activity in the tanks is not included. The values shown on Table 8 are the sum of these numbers and the other three columns shown on the previous table (domes intact). 
HNF-3378-Rev. 0

Table 21. Single Tank Dose Rates After Excavation (Dome Intact) -- 99 Percent Retrieval

\begin{tabular}{|c|c|c|c|c|c|c|c|c|}
\hline Detector Location & \multicolumn{2}{|c|}{$\begin{array}{l}\text { No Shield } \\
\mathrm{mrem} / \mathrm{h} \% \mathrm{RE}\end{array}$} & \multicolumn{2}{|c|}{$\begin{array}{l}70.5 \mathrm{lb} / \mathrm{ft}^{2} \\
\mathrm{mrem} / \mathrm{h} \% \mathrm{RE}\end{array}$} & \multicolumn{2}{|c|}{$\begin{array}{l}141 \mathrm{lb} / \mathrm{ft}^{2} \\
\mathrm{mrem} / \mathrm{h} \% \mathrm{RE}\end{array}$} & \multicolumn{2}{|c|}{$\begin{array}{l}211.5 \mathrm{lb} / \mathrm{ft}^{2} \\
\mathrm{mrem} / \mathrm{h} \% \mathrm{RE}\end{array}$} \\
\hline $\begin{array}{l}\text { Tank AX-101 Source } \\
3 \mathrm{ft} \text { Below Dome } \\
\text { Center of Tank } \\
\text { Midway to Edge } \\
\text { Inner Edge of Tank } \\
\text { Bottom Edge of Excavation } \\
\text { Upper Edge of Excavation } \\
50 \mathrm{ft} \text { from Excavation } \\
100 \mathrm{ft} \text { from Excavation } \\
150 \mathrm{ft} \text { from Excavation } \\
200 \mathrm{ft} \text { from Excavation } \\
300 \mathrm{ft} \text { from Excavation } \\
400 \mathrm{ft} \text { from Excavation }\end{array}$ & $\begin{array}{l}2.9 \mathrm{E}+03 \\
8.7 \mathrm{E}+00 \\
6.8 \mathrm{E}+00 \\
1.1 \mathrm{E}-01 \\
5.8 \mathrm{E}-02 \\
7.2 \mathrm{E}-02 \\
1.7 \mathrm{E}-02 \\
1.0 \mathrm{E}-02 \\
6.4 \mathrm{E}-03 \\
4.7 \mathrm{E}-03 \\
2.5 \mathrm{E}-03 \\
1.5 \mathrm{E}-03\end{array}$ & $\begin{array}{l}0.2 \\
3.2 \\
3.8 \\
7.9 \\
3.8 \\
2.0 \\
3.5 \\
6.4 \\
6.4 \\
8.9 \\
6.7 \\
16.7\end{array}$ & $\begin{array}{l}3.7 \mathrm{E}+02 \\
9.5 \mathrm{E}-01 \\
6.7 \mathrm{E}-01 \\
1.1 \mathrm{E}-02 \\
5.7 \mathrm{E}-03 \\
7.6 \mathrm{E}-03 \\
1.8 \mathrm{E}-03 \\
9.5 \mathrm{E}-04 \\
6.5 \mathrm{E}-04 \\
4.3 \mathrm{E}-04 \\
2.0 \mathrm{E}-04 \\
1.3 \mathrm{E}-04\end{array}$ & $\begin{array}{l}0.3 \\
5.1 \\
6.2 \\
6.1 \\
3.8 \\
4.0 \\
7.0 \\
3.5 \\
6.3 \\
5.7 \\
4.1 \\
11.3\end{array}$ & $\begin{array}{l}3.6 \mathrm{E}+01 \\
1.1 \mathrm{E}-01 \\
6.0 \mathrm{E}-02 \\
8.7 \mathrm{E}-04 \\
5.7 \mathrm{E}-04 \\
6.4 \mathrm{E}-04 \\
1.6 \mathrm{E}-04 \\
1.2 \mathrm{E}-04 \\
6.1 \mathrm{E}-05 \\
4.2 \mathrm{E}-05 \\
2.2 \mathrm{E}-05 \\
2.6 \mathrm{E}-05\end{array}$ & $\begin{array}{r}0.5 \\
11.0 \\
8.3 \\
7.7 \\
9.5 \\
5.6 \\
5.1 \\
22.9 \\
6.3 \\
7.3 \\
9.4 \\
53.4\end{array}$ & $\begin{array}{l}3.2 \mathrm{E}+00 \\
6.1 \mathrm{E}-03 \\
5.7 \mathrm{E}-03 \\
9.7 \mathrm{E}-05 \\
4.9 \mathrm{E}-05 \\
5.7 \mathrm{E}-05 \\
1.3 \mathrm{E}-05 \\
8.8 \mathrm{E}-06 \\
5.9 \mathrm{E}-06 \\
4.2 \mathrm{E}-06 \\
1.6 \mathrm{E}-06 \\
9.8 \mathrm{E}-07\end{array}$ & $\begin{array}{r}0.8 \\
11.4 \\
22.3 \\
18.8 \\
9.9 \\
8.0 \\
7.3 \\
13.9 \\
17.8 \\
22.4 \\
8.0 \\
9.5\end{array}$ \\
\hline $\begin{array}{l}\text { Tank AX-102 Source } \\
3 \mathrm{ft} \text { Below Dome } \\
\text { Center of Tank } \\
\text { Midway to Edge } \\
\text { Inner Edge of Tank } \\
\text { Bottom Edge of Excavation } \\
\text { Upper Edge of Excavation } \\
50 \mathrm{ft} \text { from Excavation } \\
100 \mathrm{ft} \text { from Excavation } \\
150 \mathrm{ft} \text { from Excavation } \\
200 \mathrm{ft} \text { from Excavation } \\
300 \mathrm{ft} \text { from Excavation } \\
400 \mathrm{ft} \text { from Excavation }\end{array}$ & $\begin{array}{l}2.1 \mathrm{E}+04 \\
5.8 \mathrm{E}+01 \\
4.3 \mathrm{E}+01 \\
7.1 \mathrm{E}-01 \\
3.9 \mathrm{E}-01 \\
4.9 \mathrm{E}-01 \\
1.2 \mathrm{E}-01 \\
7.6 \mathrm{E}-02 \\
4.4 \mathrm{E}-02 \\
3.1 \mathrm{E}-02 \\
1.6 \mathrm{E}-02 \\
9.2 \mathrm{E}-03\end{array}$ & $\begin{array}{r}0.2 \\
3.1 \\
4.0 \\
3.9 \\
4.7 \\
2.0 \\
4.4 \\
10.5 \\
5.0 \\
6.8 \\
5.0 \\
7.5\end{array}$ & $\begin{array}{l}2.6 E+03 \\
5.5 E+00 \\
4.6 E+00 \\
6.7 E-02 \\
3.7 E-02 \\
5.1 E-02 \\
1.2 E-02 \\
6.4 E-03 \\
4.1 E-03 \\
2.8 E-03 \\
1.5 E-03 \\
8.8 E-04\end{array}$ & $\begin{array}{l}0.3 \\
4.4 \\
6.4 \\
5.8 \\
6.8 \\
5.6 \\
8.1 \\
6.8 \\
5.4 \\
4.3 \\
7.1 \\
7.1\end{array}$ & $\begin{array}{l}2.4 \mathrm{E}+02 \\
6.8 \mathrm{E}-01 \\
5.0 \mathrm{E}-01 \\
5.5 \mathrm{E}-03 \\
3.4 \mathrm{E}-03 \\
4.1 \mathrm{E}-03 \\
1.0 \mathrm{E}-03 \\
5.5 \mathrm{E}-04 \\
4.9 \mathrm{E}-04 \\
2.3 \mathrm{E}-04 \\
1.7 \mathrm{E}-04 \\
7.3 \mathrm{E}-05\end{array}$ & $\begin{array}{r}0.5 \\
13.2 \\
14.4 \\
8.1 \\
10.6 \\
4.0 \\
6.5 \\
4.7 \\
18.8 \\
4.7 \\
31.3 \\
9.2\end{array}$ & $\begin{array}{l}2.2 \mathrm{E}+01 \\
6.1 \mathrm{E}-02 \\
2.8 \mathrm{E}-02 \\
4.9 \mathrm{E}-04 \\
2.7 \mathrm{E}-04 \\
3.8 \mathrm{E}-04 \\
9.0 \mathrm{E}-05 \\
5.9 \mathrm{E}-05 \\
3.7 \mathrm{E}-05 \\
2.5 \mathrm{E}-05 \\
2.3 \mathrm{E}-05 \\
\text { 8.1E-06 }\end{array}$ & $\begin{array}{r}1.0 \\
18.9 \\
12.6 \\
11.3 \\
7.6 \\
6.5 \\
9.2 \\
12.4 \\
10.6 \\
11.5 \\
50.0 \\
24.7\end{array}$ \\
\hline
\end{tabular}


HNF-3378-Rev. 0

Table 21. Single Tank Dose Rates After Excavation (Dome Intact) -- 99 Percent Retrieval (cont'd)

\begin{tabular}{|c|c|c|c|c|c|c|c|c|}
\hline Detector Location & $\begin{array}{c}\text { No Sh } \\
\text { mrem/h }\end{array}$ & $\underset{\%}{e l d} \operatorname{RE}$ & $\begin{array}{l}70.5 \mathrm{lb} \\
\mathrm{mrem} / \mathrm{h}\end{array}$ & $\begin{array}{l}/ \mathrm{ft}^{2} \\
\% \mathrm{RE}\end{array}$ & $\begin{array}{l}141 \mathrm{lb} / \\
\text { mrem } / \mathrm{h}\end{array}$ & $\mathrm{ft}_{\%}^{2} \mathrm{RE}$ & $\begin{array}{l}211.5 \\
\text { mrem/h }\end{array}$ & $\begin{array}{l}\mathrm{b} / \mathrm{ft}^{2} \\
\% \mathrm{RE}\end{array}$ \\
\hline $\begin{array}{l}\text { Tank AX-103/104 Source } \\
3 \mathrm{ft} \text { Below Dome } \\
\text { Center of Tank } \\
\text { Midway to Edge } \\
\text { Inner Edge of Tank } \\
\text { Bottom Edge of Excavation } \\
\text { Upper Edge of Excavation } \\
50 \mathrm{ft} \text { from Excavation } \\
100 \mathrm{ft} \text { from Excavation } \\
150 \mathrm{ft} \text { from Excavation } \\
200 \mathrm{ft} \text { from Excavation } \\
300 \mathrm{ft} \text { from Excavation } \\
400 \mathrm{ft} \text { from Excavation }\end{array}$ & $\begin{array}{l}3.1 \mathrm{E}+04 \\
8.3 \mathrm{E}+01 \\
6.3 \mathrm{E}+01 \\
1.1 \mathrm{E}+00 \\
5.2 \mathrm{E}-01 \\
7.3 \mathrm{E}-01 \\
1.5 \mathrm{E}-01 \\
9.6 \mathrm{E}-02 \\
6.8 \mathrm{E}-02 \\
4.2 \mathrm{E}-02 \\
2.3 \mathrm{E}-02 \\
1.2 \mathrm{E}-02\end{array}$ & $\begin{array}{r}0.2 \\
5.6 \\
7.7 \\
9.3 \\
7.6 \\
5.2 \\
7.2 \\
8.3 \\
17.2 \\
12.8 \\
12.6 \\
8.5\end{array}$ & $\begin{array}{l}3.3 \mathrm{E}+03 \\
1.1 \mathrm{E}+01 \\
6.4 \mathrm{E}+00 \\
9.2 \mathrm{E}-02 \\
5.1 \mathrm{E}-02 \\
8.3 \mathrm{E}-02 \\
1.5 \mathrm{E}-02 \\
1.4 \mathrm{E}-02 \\
6.8 \mathrm{E}-03 \\
4.1 \mathrm{E}-03 \\
\text { 2. } 8 \mathrm{E}-03 \\
1.2 \mathrm{E}-03\end{array}$ & $\begin{array}{r}0.5 \\
8.4 \\
8.8 \\
5.2 \\
4.7 \\
11.0 \\
3.9 \\
21.2 \\
10.3 \\
5.2 \\
24.1 \\
6.1\end{array}$ & $\begin{array}{l}3.3 \mathrm{E}+02 \\
1.7 \mathrm{E}+00 \\
9.9 \mathrm{E}-01 \\
1.3 \mathrm{E}-02 \\
6.8 \mathrm{E}-03 \\
9.8 \mathrm{E}-03 \\
2.1 \mathrm{E}-03 \\
1.3 \mathrm{E}-03 \\
7.4 \mathrm{E}-04 \\
4.5 \mathrm{E}-04 \\
2.2 \mathrm{E}-04 \\
1.3 \mathrm{E}-04\end{array}$ & $\begin{array}{r}0.8 \\
21.5 \\
21.4 \\
11.3 \\
7.7 \\
7.9 \\
11.5 \\
9.8 \\
11.1 \\
6.0 \\
5.2 \\
6.8\end{array}$ & $\begin{array}{l}3.4 \mathrm{E}+01 \\
2.0 \mathrm{E}-01 \\
1.0 \mathrm{E}-01 \\
1.5 \mathrm{E}-03 \\
7.8 \mathrm{E}-04 \\
1.1 \mathrm{E}-03 \\
2.3 \mathrm{E}-04 \\
1.2 \mathrm{E}-04 \\
8.2 \mathrm{E}-05 \\
5.1 \mathrm{E}-05 \\
5.4 \mathrm{E}-05 \\
2.0 \mathrm{E}-05\end{array}$ & $\begin{array}{r}1.4 \\
23.0 \\
22.9 \\
16.1 \\
10.7 \\
8.9 \\
9.8 \\
7.4 \\
9.4 \\
7.4 \\
52.7 \\
17.0\end{array}$ \\
\hline
\end{tabular}

Note: Dose rates are computed at a height of 3 feet above the surfaces. 
HNF-3378-Rev. 0

Table 22. Single Tank Dose Rates With Dome Removed -- 99 Percent Retrieval

\begin{tabular}{|c|c|c|c|c|c|c|c|c|}
\hline Detector Location & \multicolumn{2}{|c|}{ No Shield } & \multicolumn{2}{|c|}{$70.5 \mathrm{lb} / \mathrm{ft}^{2}$} & \multicolumn{2}{|c|}{$141 \mathrm{lb} / \mathrm{ft}^{2}$} & \multicolumn{2}{|c|}{$211.5 \mathrm{lb} / \mathrm{ft}^{2}$} \\
\hline $\begin{array}{l}\text { Tank AX-101 Source } \\
3 \mathrm{ft} \text { Below Dome } \\
\text { Center of Tank } \\
\text { Midway to Edge } \\
\text { Inner Edge of Tank } \\
\text { Bottom Edge of Excavation } \\
\text { Upper Edge of Excavation } \\
50 \mathrm{ft} \text { from Excavation } \\
100 \mathrm{ft} \text { from Excavation } \\
150 \mathrm{ft} \text { from Excavation } \\
200 \mathrm{ft} \text { from Excavation } \\
300 \mathrm{ft} \text { from Excavation } \\
400 \mathrm{ft} \text { from Excavation }\end{array}$ & $\begin{array}{l}2.5 \mathrm{E}+03 \\
1.9 \mathrm{E}+03 \\
1.9 \mathrm{E}+03 \\
1.5 \mathrm{E}+03 \\
3.6 \mathrm{E}+01 \\
\text { 3. } 6 \mathrm{E}+01 \\
8.7 \mathrm{E}+00 \\
5.1 \mathrm{E}+00 \\
3.2 \mathrm{E}+00 \\
2.5 \mathrm{E}+00 \\
1.3 \mathrm{E}+00 \\
\text { 8.0E-01 }\end{array}$ & $\begin{array}{l}0.9 \\
0.5 \\
0.3 \\
0.4 \\
3.2 \\
2.0 \\
3.6 \\
4.3 \\
2.9 \\
6.5 \\
7.9 \\
8.3\end{array}$ & $\begin{array}{l}3.1 \mathrm{E}+02 \\
2.6 \mathrm{E}+02 \\
2.4 \mathrm{E}+02 \\
1.6 \mathrm{E}+02 \\
4.2 \mathrm{E}+00 \\
4.0 \mathrm{E}+00 \\
1.1 \mathrm{E}+00 \\
6.2 \mathrm{E}-01 \\
4.2 \mathrm{E}-01 \\
\text { 3.1E-01 } \\
1.4 \mathrm{E}-01 \\
9.8 \mathrm{E}-02\end{array}$ & $\begin{array}{l}0.4 \\
0.3 \\
0.5 \\
0.5 \\
2.7 \\
2.3 \\
3.9 \\
2.7 \\
3.0 \\
5.3 \\
2.8 \\
11.7\end{array}$ & $\begin{array}{l}\text { 3. } 0 \mathrm{E}+01 \\
2.5 \mathrm{E}+01 \\
2.3 \mathrm{E}+01 \\
1.4 \mathrm{E}+01 \\
4.6 \mathrm{E}-01 \\
\text { 3. } 9 \mathrm{E}-01 \\
1.3 \mathrm{E}-01 \\
\text { 7. } 5 \mathrm{E}-02 \\
4.4 \mathrm{E}-02 \\
2.7 \mathrm{E}-02 \\
1.4 \mathrm{E}-02 \\
\text { 8. } 4 \mathrm{E}-03\end{array}$ & $\begin{array}{r}0.7 \\
0.5 \\
0.5 \\
0.7 \\
3.8 \\
2.4 \\
9.0 \\
11.7 \\
7.2 \\
3.3 \\
2.6 \\
7.0\end{array}$ & $\begin{array}{l}\text { 2. } 8 \mathrm{E}+00 \\
2.3 \mathrm{E}+00 \\
2.1 \mathrm{E}+00 \\
1.2 \mathrm{E}+00 \\
\text { 3. } 8 \mathrm{E}-02 \\
3.4 \mathrm{E}-02 \\
9.6 \mathrm{E}-03 \\
5.6 \mathrm{E}-03 \\
\text { 3. } 8 \mathrm{E}-03 \\
\text { 3. } \mathrm{E}-03 \\
1.4 \mathrm{E}-03 \\
7.6 \mathrm{E}-04\end{array}$ & $\begin{array}{r}2.2 \\
0.8 \\
0.9 \\
1.1 \\
3.1 \\
2.5 \\
3.9 \\
4.4 \\
6.9 \\
22.3 \\
8.9 \\
7.7\end{array}$ \\
\hline $\begin{array}{l}\text { Tank AX-102 Source } \\
3 \text { ft Below Dome } \\
\text { Center of Tank } \\
\text { Midway to Edge } \\
\text { Inner Edge of Tank } \\
\text { Bottom Edge of Excavation } \\
\text { Upper Edge of Excavation } \\
50 \mathrm{ft} \text { from Excavation } \\
100 \mathrm{ft} \text { from Excavation } \\
150 \mathrm{ft} \text { from Excavation } \\
200 \mathrm{ft} \text { from Excavation } \\
300 \mathrm{ft} \text { from Excavation } \\
400 \mathrm{ft} \text { from Excavation }\end{array}$ & $\begin{array}{l}1.8 \mathrm{E}+04 \\
1.4 \mathrm{E}+04 \\
1.3 \mathrm{E}+04 \\
1.1 \mathrm{E}+04 \\
2.8 \mathrm{E}+02 \\
2.7 \mathrm{E}+02 \\
6.8 \mathrm{E}+01 \\
4.2 \mathrm{E}+01 \\
2.4 \mathrm{E}+01 \\
1.7 \mathrm{E}+01 \\
1.0 \mathrm{E}+01 \\
\text { 5.0E+00 }\end{array}$ & $\begin{array}{r}0.9 \\
0.5 \\
0.3 \\
0.4 \\
3.1 \\
1.7 \\
4.3 \\
6.8 \\
2.8 \\
3.6 \\
19.1 \\
5.2\end{array}$ & $\begin{array}{l}2.2 \mathrm{E}+03 \\
1.8 \mathrm{E}+03 \\
1.6 \mathrm{E}+03 \\
1.1 \mathrm{E}+03 \\
3.0 \mathrm{E}+01 \\
2.7 \mathrm{E}+01 \\
7.3 \mathrm{E}+00 \\
4.4 \mathrm{E}+00 \\
2.8 \mathrm{E}+00 \\
2.1 \mathrm{E}+00 \\
1.0 \mathrm{E}+00 \\
5.9 \mathrm{E}-01\end{array}$ & $\begin{array}{l}0.3 \\
0.3 \\
0.7 \\
0.8 \\
2.8 \\
1.7 \\
2.6 \\
4.0 \\
3.2 \\
5.8 \\
3.4 \\
7.5\end{array}$ & $\begin{array}{l}2.0 E+02 \\
1.7 E+02 \\
1.5 E+02 \\
9.5 E+01 \\
2.9 E+00 \\
2.5 E+00 \\
6.9 E-01 \\
4.6 E-01 \\
2.8 E-01 \\
1.8 E-01 \\
9.9 E-02 \\
5.6 E-02\end{array}$ & $\begin{array}{l}0.6 \\
0.5 \\
0.6 \\
0.8 \\
3.1 \\
1.8 \\
2.2 \\
5.5 \\
3.7 \\
3.7 \\
5.8 \\
7.8\end{array}$ & $\begin{array}{l}1.8 \mathrm{E}+01 \\
1.5 \mathrm{E}+01 \\
1.4 \mathrm{E}+01 \\
8.2 \mathrm{E}+00 \\
2.5 \mathrm{E}-01 \\
2.2 \mathrm{E}-01 \\
6.5 \mathrm{E}-02 \\
4.0 \mathrm{E}-02 \\
\text { 2. } 3 \mathrm{E}-02 \\
1.7 \mathrm{E}-02 \\
\text { 8. } 6 \mathrm{E}-03 \\
4.8 \mathrm{E}-03\end{array}$ & $\begin{array}{l}2.3 \\
0.9 \\
0.9 \\
1.1 \\
4.4 \\
2.2 \\
3.4 \\
5.6 \\
3.6 \\
4.0 \\
6.1 \\
7.9\end{array}$ \\
\hline
\end{tabular}


HNF-3378-Rev. 0

Table 22. Single Tank Dose Rates With Dome Removed -- 99 Percent Retrieval

\begin{tabular}{|c|c|c|c|c|c|c|c|c|}
\hline Detector Location & \multicolumn{2}{|c|}{ No Shield } & \multicolumn{2}{|c|}{$70.51 \mathrm{~b} / \mathrm{ft}^{2}$} & \multicolumn{2}{|c|}{$\begin{array}{l}141 \mathrm{lb} / \mathrm{ft}^{2} \\
\mathrm{mrem} / \mathrm{h} \% \mathrm{RE}\end{array}$} & \multicolumn{2}{|c|}{$\begin{array}{l}211.51 \mathrm{~b} / \mathrm{ft}^{2} \\
\mathrm{mrem} / \mathrm{h}\end{array}$} \\
\hline $\begin{array}{l}\text { Tank AX-103/104 Source } \\
3 \mathrm{ft} \text { Below Dome } \\
\text { Center of Tank } \\
\text { Midway to Edge } \\
\text { Inner Edge of Tank } \\
\text { Bottom Edge of Excavation } \\
\text { Upper Edge of Excavation } \\
50 \mathrm{ft} \text { from Excavation } \\
100 \mathrm{ft} \text { from Excavation } \\
150 \mathrm{ft} \text { from Excavation } \\
200 \mathrm{ft} \text { from Excavation } \\
300 \mathrm{ft} \text { from Excavation } \\
400 \mathrm{ft} \text { from Excavation }\end{array}$ & $\begin{array}{l}2.7 \mathrm{E}+04 \\
2.1 \mathrm{E}+04 \\
2.0 \mathrm{E}+04 \\
1.6 \mathrm{E}+04 \\
4.6 \mathrm{E}+02 \\
4.5 \mathrm{E}+02 \\
1.2 \mathrm{E}+02 \\
6.9 \mathrm{E}+01 \\
3.9 \mathrm{E}+01 \\
2.6 \mathrm{E}+01 \\
1.4 \mathrm{E}+01 \\
7.3 \mathrm{E}+00\end{array}$ & $\begin{array}{l}1.7 \\
0.3 \\
0.3 \\
0.5 \\
2.6 \\
2.5 \\
5.9 \\
6.7 \\
2.4 \\
2.7 \\
5.2 \\
4.0\end{array}$ & $\begin{array}{l}2.8 \mathrm{E}+03 \\
2.3 \mathrm{E}+03 \\
2.1 \mathrm{E}+03 \\
1.4 \mathrm{E}+03 \\
3.7 \mathrm{E}+01 \\
3.5 \mathrm{E}+01 \\
1.2 \mathrm{E}+01 \\
5.3 \mathrm{E}+00 \\
3.4 \mathrm{E}+00 \\
2.6 \mathrm{E}+00 \\
1.4 \mathrm{E}+00 \\
7.1 \mathrm{E}-01\end{array}$ & $\begin{array}{r}1.2 \\
0.8 \\
0.6 \\
0.7 \\
3.9 \\
3.0 \\
10.3 \\
2.7 \\
3.0 \\
5.8 \\
8.5 \\
7.1\end{array}$ & $\begin{array}{l}2.8 \mathrm{E}+02 \\
2.4 \mathrm{E}+02 \\
2.1 \mathrm{E}+02 \\
1.3 \mathrm{E}+02 \\
3.5 \mathrm{E}+00 \\
3.2 \mathrm{E}+00 \\
9.2 \mathrm{E}-01 \\
6.0 \mathrm{E}-01 \\
3.4 \mathrm{E}-01 \\
2.5 \mathrm{E}-01 \\
1.3 \mathrm{E}-01 \\
6.3 \mathrm{E}-02\end{array}$ & $\begin{array}{r}0.9 \\
0.9 \\
1.0 \\
1.3 \\
4.0 \\
3.0 \\
4.0 \\
10.1 \\
3.3 \\
8.0 \\
8.1 \\
4.7\end{array}$ & $\begin{array}{l}2.9 \mathrm{E}+01 \\
2.5 \mathrm{E}+01 \\
2.2 \mathrm{E}+01 \\
1.3 \mathrm{E}+01 \\
3.7 \mathrm{E}-01 \\
3.2 \mathrm{E}-01 \\
8.6 \mathrm{E}-02 \\
5.0 \mathrm{E}-02 \\
3.4 \mathrm{E}-02 \\
2.9 \mathrm{E}-02 \\
1.3 \mathrm{E}-02 \\
7.2 \mathrm{E}-03\end{array}$ & $\begin{array}{r}1.7 \\
1.6 \\
1.8 \\
2.0 \\
5.1 \\
3.0 \\
3.5 \\
4.2 \\
5.8 \\
18.9 \\
8.6 \\
8.8\end{array}$ \\
\hline
\end{tabular}


HNF-3378-Rev. 0

ATTACHMENT 4

ISO-PC INPUT FOR TANK DEBRIS REMOVAL 
HNF-3378-Rev. 0

Table 23. $4 \mathrm{~m}^{2}$ Source Representing Exposed Tank Bottom

02 Dose Rates Near 241-AX Exposed Waste $-4 \mathrm{~m}^{2}$

101-AX at 10.15,20.25.30.35,40,50,70,100 feet

\&Input IGeom=9. SLTH= 112.84, T= 7.62,0.953. NSh $7 d=2, \quad J B u f=1$,

$X=313.37,465.77,618.17 .770 .57,922.97 .1075 .37 .1227 .77 .1532 .57$.

2142.17.3056.57. NTheta $=53$, DUnit $=1$. SFact $=0.01151$, DosePrfx $=-3$,

Weight $(472)=2.2$. Weight $(82)=7238.0, \quad$ Weight $(84)=7238.0$.

Weight $(141)=1.70$. Weight $(269)=0.00 . \quad$ Weight $(270)=0.00$.

Weight $(335)=1684$. Weight $(336)=1593.1$. Weight $(403)=0.05$.

Weight (415) $=0.0$. Weight $(418)=0.0 \quad$ \&

Ag $38 \quad 0.0005$

Al $\quad 7 \quad 0.0454$

$\begin{array}{lll}\mathrm{Ba} & 39 & 0.0008\end{array}$

Bi $14 \quad 0,0017$

Ca $33 \quad 0.0026$

C] $30 \quad 0.0135$

$\begin{array}{lll}\mathrm{CO} & 23 & 0.0368\end{array}$

$\begin{array}{lll}\mathrm{Cr} & 34 & 0.0122\end{array}$

$\begin{array}{lll}\mathrm{Fe} & 9 & 0.0279\end{array}$

$\begin{array}{lll}k & 32 & 0.0049\end{array}$

$\begin{array}{lll}\text { La } & 39 & 0.0002\end{array}$

Mn $34 \quad 0.0046$

$\begin{array}{lll}\mathrm{Na} & 25 & 0.2586\end{array}$

$\mathrm{Ni} \quad 10 \quad 0.0008$

NOX $23 \quad 0.3610$

$\begin{array}{lll}0 & 23 & 0.1998\end{array}$

$\mathrm{Pb} \quad 14 \quad 0.0022$

$\mathrm{PO4} 28 \quad 0.0170$

Si $27 \quad 0.0166$

$504 \quad 29 \quad 0.0077$

Sr $\quad 18 \quad 0.0001$

$\begin{array}{lll}C & 6 & 0.0186\end{array}$

$\begin{array}{lll}\text { U } & 15 & 0.0392\end{array}$

$\begin{array}{lll}\mathrm{Zr} & 11 & 0.0016\end{array}$

$\begin{array}{lll}1 \mathrm{H} 2 \mathrm{O} & 1 & 0.5608\end{array}$

102-AX

\&Input Weight $(472)=0.0$. Weight $(82)=82340.0$. Weight $(84)=82340.0$.

Weight $(141)=3.80$. Weight $(269)=0.00 . \quad$ Weight $(270)=0.00$.

Weight $(335)=11195$. Weight $(336)=10590.5$. Weight $(403)=1480$.

Weight $(415)=0.0$. Weight $(418)=0.0$ \&

A) $7 \quad 0.0486$

Ca $33 \quad 0.0079$

$\begin{array}{lll}\mathrm{Cl} & 30 & 0.0012\end{array}$

$\begin{array}{lll}\mathrm{CO} 3 & 23 & 0.0272\end{array}$

$\begin{array}{lll}\mathrm{Cr} & 34 & 0.0002\end{array}$

$\begin{array}{lll}\text { Fe } & 9 & 0.1422\end{array}$

$\begin{array}{lll}\text { K } & 32 & 0.0003\end{array}$

Mn $34 \quad 0.0120$

$\begin{array}{lll}\mathrm{Na} & 25 & 0.1187\end{array}$

$\mathrm{Ni} \quad 10 \quad 0.0054$

NoX $23 \quad 0.0580$

$\begin{array}{lll}0 & 23 & 0.4262\end{array}$

$\begin{array}{lll}\mathrm{P} 04 & 28 & 0.0023\end{array}$

Si $\quad 27 \quad 0.0353$

$\begin{array}{lll}\mathrm{SO} & 29 & 0.0033\end{array}$

$\begin{array}{lll}\mathrm{U} & 15 & 0.0140\end{array}$

$\begin{array}{llll}1 & H 2 O & 1 & 0.6673\end{array}$

7.86 
HNF-3378-Rev. 0

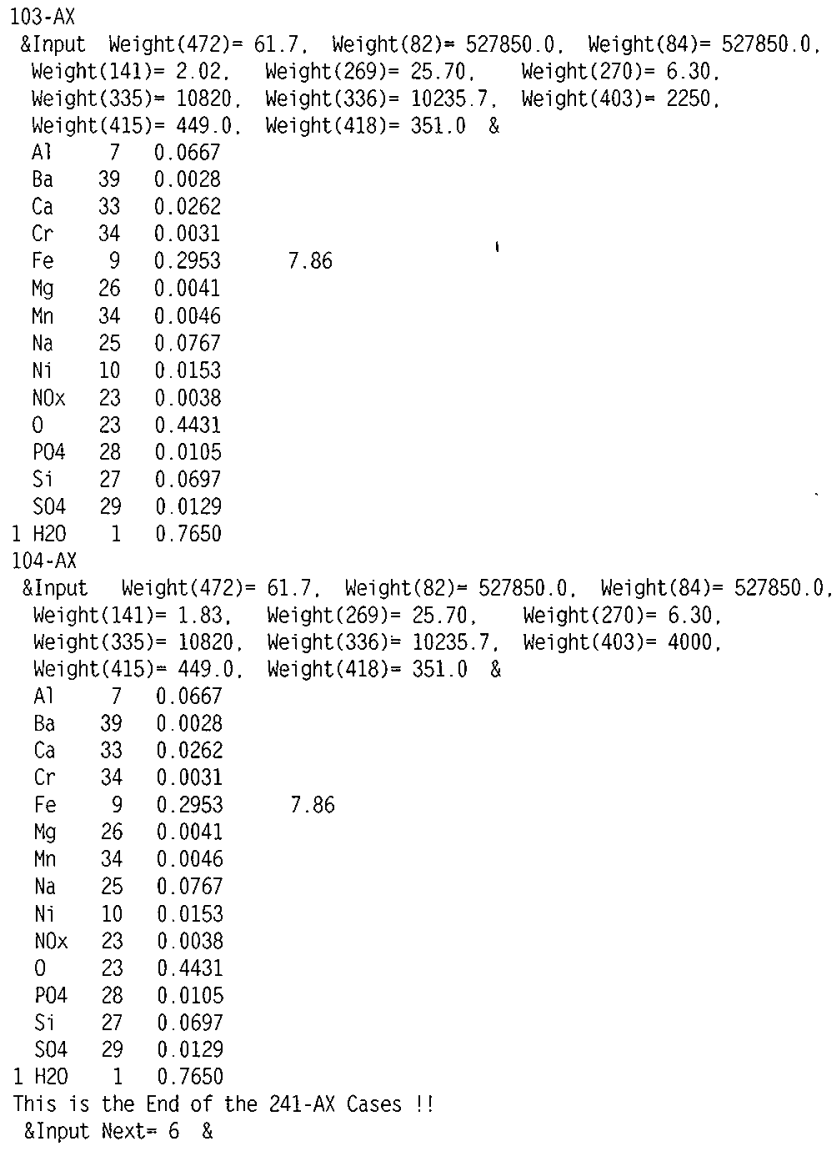


HNF-3378-Rev, 0

Table 24. $4 \mathrm{~m}^{2}$ Source Representing Debris Removal -- 2 inches of Iron Shielding

2 Dose Rates Near 241-AX Exposed Waste .- 2 inch Fe Shield

101-AX at $10,15,20,25,30,35,40.50,70,100$ feet

\&Input IGeom=9. SLTH= 112.84. T=7.62.6.033. NShld=2. JBuf=2, $X=313.37,465.77,618.17,770.57,922.97,1075.37,1227,77,1532.57$.

2142.17, 3056.57. NTheta $=53$. DUnit $=1$. SFact $=0.01151$, DosePrfx $=-3$, Weight $(472)=2.2$. Weight $(82)=7238.0$. Weight $(84)=7238.0$.

Weight $(141)=1.70$. Weight $(269)=0.00$. Weight $(270)=0.00$.

Weight $(335)=1684$. Weight $(336)=1593.1$. Weight $(403)=0.05$.

Weight (415) $=0.0$. Weight $(418)=0.0 \&$

$\mathrm{Ag} \quad 38 \quad 0.0005$

A1 $\quad 7 \quad 0.0454$

$\begin{array}{lll}\text { Ba } & 39 & 0.0008\end{array}$

$\begin{array}{lll}\text { Bi } & 14 & 0.0017\end{array}$

$\begin{array}{lll}\mathrm{Ca} & 33 & 0.0026\end{array}$

C1 $30 \quad 0.0135$

$\begin{array}{lll}\mathrm{CO} 3 & 23 & 0.0368\end{array}$

$\begin{array}{lll}\mathrm{Cr} & 34 & 0.0122\end{array}$

$\begin{array}{lll}\text { Fe } & 9 & 0.0279\end{array}$

$\begin{array}{lll}K \quad 32 & 0.0049\end{array}$

$\begin{array}{lll}\text { La } & 39 & 0.0002\end{array}$

$\begin{array}{lll}\text { Mn } & 34 & 0.0046\end{array}$

$\begin{array}{lll}\mathrm{Na} & 25 & 0.2586\end{array}$

$\begin{array}{lll}\mathrm{Ni} & 10 & 0.0008\end{array}$

NOX $23 \quad 0.3610$

$\begin{array}{lll}0 & 23 & 0.1998\end{array}$

$\begin{array}{lll}\mathrm{Pb} & 14 & 0.0022\end{array}$

P04 $28 \quad 0.0170$

Si $\quad 27 \quad 0.0166$

$\begin{array}{lll}\mathrm{S} 04 & 29 & 0.0077\end{array}$

$\begin{array}{lll}\mathrm{Sr} & 18 & 0.0001\end{array}$

$\begin{array}{lll}C & 6 & 0.0186\end{array}$

$\begin{array}{lll}\text { U } & 15 & 0.0392\end{array}$

$\begin{array}{lll}2 r & 11 & 0.0016\end{array}$

$\begin{array}{llll}1 \mathrm{H} 2 \mathrm{O} & 1 & 0.5608\end{array}$

102-AX

\&Input Weight $(472)=0.0$. Weight $(82)=82340.0$. Weight $(84)=82340.0$. Weight $(141)=3.80$. Weight $(269)=0.00$. Weight $(270)=0.00$.

Weight $(335)=11195$. Weight $(336)=10590.5$. Weight $(403)=1480$,

Weight $(415)=0.0$, Weight $(418)=0.0$ \&

A] $\quad 7 \quad 0.0486$

$\begin{array}{lll}\text { Ca } & 33 & 0.0079\end{array}$

$\begin{array}{lll}\mathrm{Cl} & 30 & 0.0012\end{array}$

$\begin{array}{lll}\mathrm{CO} & 23 & 0.0272\end{array}$

$\begin{array}{lll}\mathrm{Cr} & 34 & 0.0002\end{array}$

$\begin{array}{lll}\mathrm{Fe} & 9 & 0.1422\end{array}$

$\begin{array}{lll}K & 32 & 0.0003\end{array}$

$\begin{array}{lll}\text { Mn } \quad 34 & 0.0120\end{array}$

$\begin{array}{lll}\mathrm{Na} & 25 & 0.1187\end{array}$

Ni $10 \quad 0.0054$

NOX $23 \quad 0.0580$

$\begin{array}{lll}0 & 23 & 0.4262\end{array}$

P04 $28 \quad 0.0023$

$\begin{array}{lll}\text { Si } & 27 & 0.0353\end{array}$

S04 $29 \quad 0.0033$

$\begin{array}{lll}\mathrm{U} & 15 & 0.0140\end{array}$

$\begin{array}{llll}1 \mathrm{H} 2 \mathrm{O} & 1 & 0.6673\end{array}$ 


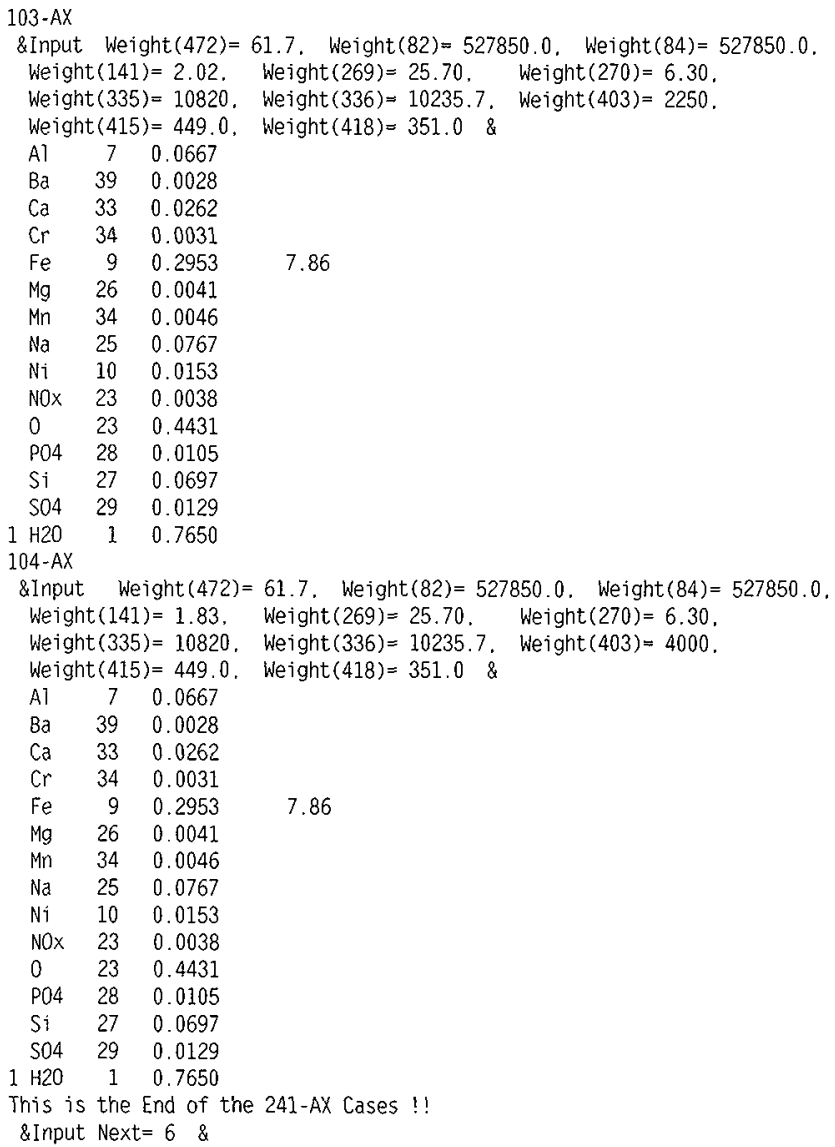


HNF-3378-Rev. 0

Table 25. ISO-PC Input File for Shipping Container Design

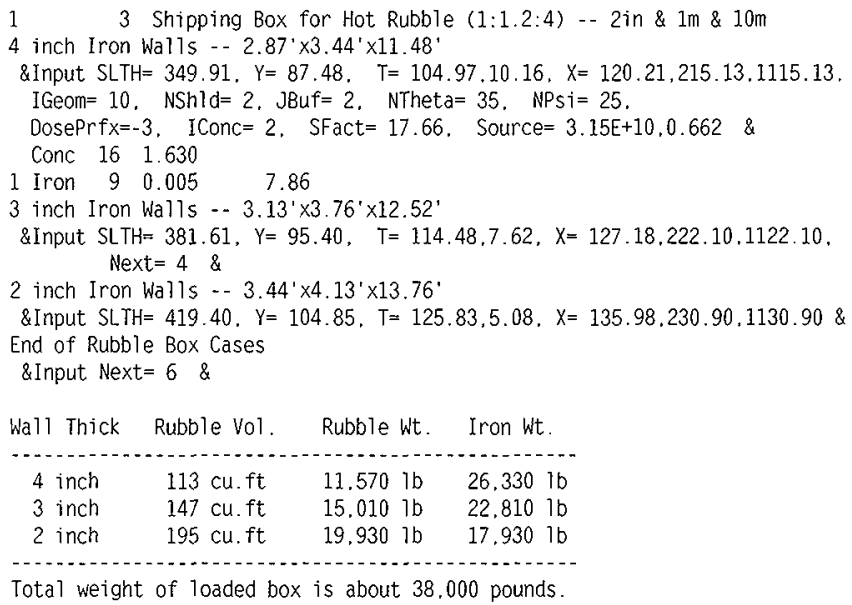

$\begin{array}{llll}4 \text { inch } & 113 \mathrm{cu} . \mathrm{ft} & 11.570 \mathrm{lb} & 26.330 \mathrm{lb} \\ 3 \text { inch } & 147 \mathrm{cu} . \mathrm{ft} & 15.010 \mathrm{lb} & 22.810 \mathrm{lb} \\ 2 \text { inch } & 195 \mathrm{cu} . \mathrm{ft} & 19.930 \mathrm{lb} & 17.930 \mathrm{lb}\end{array}$

Total weight of loaded box is about 38.000 pounds. 
HNF-3378-Rev. 0

ATTACHMENT 5

ISO-PC INPUT FILE FOR 3 INCH LAYERS

A-Att5-1 


\section{Effect of Exponential Distribution}

First 3 inches -- Sr-90

\&Input $S L T H=1688.6 . \quad$ IGeom= 9. T= 7.62. MShld=1, X=107.62.

NTheta $=93$. DUnit $=1$. DosePrf $x=-3 . \quad$ SFact $=0.9857$.

IConc $=3, \quad \operatorname{SrCPrfx}=-9 . \quad$ Weight $(82)=1,0,1 \&$

$\begin{array}{llll}1 \text { Soil } & 21 & 2.24\end{array}$

Second 3 inches $(0.25$ to 0.50 feet $)$

\&Input $T=7.62,7.62, \quad X=115.24 . \quad$ SFact $=0.9578 . \quad N S h l d=2$ \&

$\begin{array}{llll}1 \text { Soil } & 21 & 2.24 & 2.24\end{array}$

Third 3 inches (0.50 to 0.75 feet)

\&Input $T=7.62 .15 .24, \quad X=122.86 . \quad$ SFact $=0.9306 . \quad$ Next $=4$ \&

Fourth 3 inches (0.75 to 1.00 feet)

\&Input $T=7.62 .22 .86 . \quad X=130.48 . \quad S F a c t=0.9042 \quad \&$

Fifth 3 inches (1.00 to 1.25 feet)

\&Input $T=7.62 .30 .48, \quad X=138.10 . \quad$ SFact $=0.8785 \quad \&$

Sixth 3 inches (1.25 to 1.50 feet)

\&Input $T=7.62 .38 .10, \quad X=145.72 . \quad$ SFact $=0.8536 \quad$ \&

Seventh 3 inches ( 1.50 to 1.75 feet)

\&Input $T=7.62,45.70, \quad X=153.34 . \quad$ SFact $=0.8294 \quad \&$

Eighth 3 inches ( 1.75 to 2.00 feet)

\&Input $T=7.62 .53 .34, X=160.96$. SFact $=0.8059 \quad$ \&

First 3 inches -- Cs -137

\&Input $T=7.62 . \quad X=107.62 . \quad$ SFact $=0.9857 . \quad N S h l d=1$. Next $=1$, Weight $(82)=3 * 0$, Weight $(335)=1,0.946 \quad$ \&

$\begin{array}{lll}1 \text { Soil } & 21 & 2.24\end{array}$

Second 3 inches $(0.25$ to 0.50 feet)

\&Input $T=7.62 .7 .62, X=115.24$. SFact $=0.9578 . \quad N S h l d=2$ \&

$\begin{array}{llll}1 & \text { Soil } 21 & 2.24 & 2.24\end{array}$

Third 3 inches ( 0.50 to 0.75 feet)

\&Input $T=7.62 .15 .24, \quad X=122.86 . \quad S F a c t=0.9306 . \quad N e x t=4$ \&

Fourth 3 inches (0.75 to 1.00 feet)

\&Input $T=7.62,22.86, \quad X=130.48 . \quad$ SFact $=0.9042 \quad \&$

Fifth 3 inches (1.00 to 1.25 feet)

\&Input $T=7.62 .30 .48, \quad X=138.10 . \quad$ SFact $=0.8785 \quad$ \&

Sixth 3 inches (1.25 to 1.50 feet)

\&Input $T=7.62 .38 .10 . \quad X=145.72 . \quad$ SFact $=0.8536 \quad$ \&

Seventh 3 inches (1.50 to 1.75 feet)

\&Input $T=7.62 .45 .70, \quad X=153.34 . \quad$ SFact $=0.8294 \quad$ \&

Eighth 3 inches (1.75 to 2.00 feet)

\&Input $T=7.62 .53 .34, X=160.96 . \quad$ SFact $=0.8059 \quad \&$

This is the End of the 241-AX Layer Cases !!

\&Input Next $=6$ \& 
HNF-3378-Rev. 0

ATTACHMENT 6

ISO-PC INPUT FILE FOR 2 FOOT LAYERS 
HNF-3378-Rev. 0

12 241-AX Hot Sojl -- 2 ft Depth - $1 \mathrm{nCi} / \mathrm{g}$

$2.56 \mathrm{ft}$ radius $-. \mathrm{Sr}-90$

\&Input $S L T H=77.9, \quad[$ Geom=9. $T=60.96 . \quad N S h] d=1, X=160.96$.

NThet $a=73$, DUnit $=1$, DosePrf $=-3$.

IConc $=3 . \quad \operatorname{SrcPrfx}=-9$. Weight $(82)=1.0 .1 \&$

1 Soil $21 \quad 2.24$

$3.97 \mathrm{ft}$ radius.-

\&Input SLTH $=120.9$. Next $=4 \quad \&$

$6.16 \mathrm{ft}$ radius -- $\mathrm{Sr}-90$

\&Input SLTH $=187.6 \quad$ \&

$9.55 \mathrm{ft}$ radius .. $\$ \mathrm{Sr}-90$

\&Input SLTH= $291.2 \quad$ \&

$14.8 \mathrm{ft}$ radius $. .5 \mathrm{Sr}-90$

\&Input SLTH $=451.9 \quad$ \&

$23.0 \mathrm{ft}$ radius $-.-\mathrm{Sr}-90$

\&Input $S L T H=701.2$ \&

$35.7 \mathrm{ft}$ radius $.-5 \mathrm{~S}-90$

\&Input SLTH= 1088.1 \&

$55.4 \mathrm{ft}$ radius $--\mathrm{Sr}-90$

\&Input SLTH $=1688.6$ \&

$86.0 \mathrm{ft}$ radius $-\mathrm{Sr}-90$

\&Input SLTH= $2620.4 \quad$ \&

$133 \mathrm{ft}$ radius -. $\mathrm{Sr}-90$

\&Input $\mathrm{SLTH}=4066.4$ \&

$207 \mathrm{ft}$ radius -- $\mathrm{Sr}-90$

\&Input $\quad \mathrm{SLTH}=6310.3 \quad$ \&

$321 \mathrm{ft}$ radius .. $\mathrm{Sr}-90$

\&Input $S L T H=9792.4 \quad \&$

$499 \mathrm{ft}$ radius .. $\mathrm{Sr}-90$

\&Input SLTH= $15196 \quad$ \&

$2.56 \mathrm{ft}$ radius $. . \mathrm{CS}-137$

\&Input $S L T H=77.9$. Weight $(82)=0,0,0$, Weight $(335)=1,0.946$ \&

$3.97 \mathrm{ft}$ radius - - Cs-137

\&Input $\mathrm{SLTH}=120.9$. Next $=4 \quad$ \&

$6.16 \mathrm{ft}$ radius - - Cs-137

\&Input SLTH= $187.6 \quad$ \&

$9.55 \mathrm{ft}$ radius -- Cs-137

\&Input $\mathrm{SLTH}=291.2 \quad$ \&

$14.8 \mathrm{ft}$ radius - - Cs-137

\&Input SLTH $=451.9 \quad$ \&

$23.0 \mathrm{ft}$ radius - $\mathrm{Cs}-137$

\&Input $\mathrm{SLTH}=701.2 \quad$ \&

$35.7 \mathrm{ft}$ radius - - Cs -137

\&Input $S L T H=1088.1 \quad$ \&

$55.4 \mathrm{ft}$ radius -- Cs -137

\&Input $\mathrm{SLTH}=1688.6 \quad$ \&

«same SLTH values as Sr-90 case»>

This is the End of the 241-AX Cases !!

\&Input Next $=6$ \& 
HNF-3378-Rev. 0

ATTACHMENT 7

ISO-PC INPUT FILE FOR SQUARE SOURCES 
8.000 gallon leak -- Center - - Sr-90

\&Input IGeom=10. SLTH= 1927.1, $\quad Y=1927.1 . \quad T=60.96, \quad X=160.96$.

NTheta $=33$. NPsi $=33$. DUnit $=1$, DosePrfx $=-3, \quad$ NShld $=1$.

IConc $=3, \operatorname{SrcPrfx}=-9$. Weight $(82)=1,0.1 \&$

1 Soil $21 \quad 2.24$

8.000 gallon leak -.- Edge -.. Sr-90

\&Input $\mathrm{SLTH}=3854.2$. SFact $=0.5, \quad$ Next $=4 \quad \&$

40.000 gallon leak -- Center - Sr-90

\&Input SLTH= 2994. $Y=2994 . \quad$ SFact $=1$ \&

40.000 gallon leak -.- Edge -.- Sr-90

\&Input SLTH $=5988$. SFact $=0.5$ \&

8.000 gallon leak -- Center -- Cs-137

\&Input SLTH=1927.1, $Y=1927.1, \quad$ SFact $=1$.

Weight $(82)=3 * 0$. Weight $(335)=1.0,0.946 \quad$ \&

8.000 gallon leak -.- Edge -.- C\$-137

\&Input SLTH= 3854.2. SFact $=0.5$ \&

40.000 gal lon leak - Center - Cs-137

\&Input $\mathrm{SLTH}=2994, \quad Y=2994, \quad$ SFact $=1$ \&

40.000 gallon leak -.- Edge -.- Cs-137

\&Input $\mathrm{SLTH}=5988 . \quad$ SFact $=0.5$ \&

This is the End of the 241-AX Cases !!

\&Input Next $=6$ \& 
HNF-3378-Rev. 0

APPENDIX B

TANK REMOVAL COST ESTIMATE

B-1 
FLUOR DAHIEL HORTHWEST, INC. COGEHA ENGINEERING CORP. JOB NO. Z466AAA3

FILE NO. Z466AAA3
* * IEST - INTERACTIVE ESTIMATING * * TANK REMOVAL.

241-AX TANK FARM CLOSURE - PLANNING ESTIMATE PHMCRO1 - PROJECT COST SUMMARY
PAGE 1 OF 17

DATE $05 / 27 / 98 \quad 13: 37: 26$

BY R.OHRT

\begin{tabular}{|c|c|c|c|c|c|}
\hline & & ESCALATED & col & NGENCY & TOTAL \\
\hline $\begin{array}{l}\operatorname{SORT} \\
=\approx \approx=\Xi==\end{array}$ & 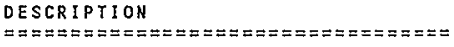 & $\begin{array}{l}\text { TOTAL COST } \\
\Rightarrow== \pm== \pm== \pm\end{array}$ & $=\stackrel{\%}{==}=$ & $\begin{array}{c}\text { TOTAL } \\
======== \pm==\end{array}$ & $\begin{array}{c}\text { DOLLARS } \\
==\approx=\pi=\approx=\approx=\end{array}$ \\
\hline B H I & BECHTEL HANFORD INTERNATIONAL & $13,600,000$ & 35 & $4,760,000$ & $18,360,000$ \\
\hline DNW & FLUOR DANIEL NORTHWEST & $24,220,000$ & 38 & $9,320,000$ & $33,540,000$ \\
\hline HHC & LOCKHEED MARTIN HANFORD CORP. & $10,530,000$ & 76 & $8,000,000$ & $18,530,000$ \\
\hline
\end{tabular}

SUBTOTAL

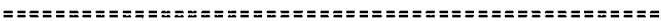

$\begin{array}{llll}48,350,000 & 46 & 22,080,000 & 70,430,000 \\ 6,810,000 & 60 & 4,090,000 & 10,900,000\end{array}$

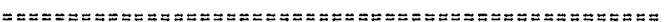

TOTAL ESTIMATED CONSTRUCTION COST (TECC)

$55,160,000$

47

$26,170,000$

$81,330,000$

REMARKS :

ESTIHATE

PLANNING ESTIMATE

MAY 27, 1998

FDNW LEAD

ESTIMATOR

PROJECT

MANAGER

CLIENT

ESTIMATINO

(-)

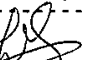

.........................

$-$
(ROUNDED/ADJUSTED TO THE NEAREST " $10,000 / 100,000 "$ - PERCENTAGES NOT RECALCULATED TO REFLECT ROUNDING) 
FLUOR DANIEL NORTHWEST, INC. COGEMA ENGINEERING CORP.

JOB NO. Z466AAA3

FILE NO. Z466AAA3

HBS DESCRIPITON

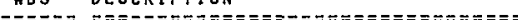

111000 DEFINITIVE DESIGH - TAKK REHOVAL

112000 DEFINITIVE DESIGH - BUILDING

113000 SAFETY ANALYSIS

119000 DEFINITIVE DESI.GH - BACXFILL

SUBTOTAL 11 DEFINITIVE DESIGN

121000 ENGR'G INSP - TANK REMOVAL

SUBTOTAL 12 ENGINEERING/INSPECTION

131000 CONSTRUCTION MANAGEMENT FOR CPAF 132000 CONSTRUCTIOH HANAGEMENT FOR F/P

SUBTOTAL 13 CONSTRUCTION MANAGEMENT

SUBTOTAL 1 ENGINEERING

210000 FONH PROCUREMENT

SUBTOTAL 21 PROCUREMENT

310100 CDF FILL TANK BOTIOMS

310200 REMOVE SOIL ABOVE TANKS

310300 PULVERIZE TANK DOMES

310400 REMOVE SOIL AT TANK SIDES

310500 REMOVE TANK WALLS

310600 REMOVE TANK BOTTOMS

SUBTOTAL 31 FA CONST-ONSITE E/C

320700 HAIN BUILDING

320800 SUPPORT FACIL $t$ TY ..

320900 BACKFILL

SUBTOTAL 32 CONSTRUCTION-FIXED PRICE
* * iest - interactive estimating **

TANK RENOVAL

241-AX TANK FARM CLOSURE - PLANNING ESTIMATE

PHMCROZ - WORK BREAKDOWN STRUCTURE (WBS) SUMMARY
PAGE 2 OF 17

DATE $05 / 27 / 98 \quad 13: 37: 32$

BY R.OHRT

\begin{tabular}{|c|c|c|c|c|c|c|c|c|}
\hline $\begin{array}{l}\text { EST IMATE } \\
\text { SUB TOTA.L } \\
=======\end{array}$ & $\begin{aligned} & E S C A \\
& \% \\
&====\end{aligned}$ & $\begin{array}{l}\text { A LATION } \\
\text { TOTAL } \\
=======\end{array}$ & $\begin{array}{c}\text { SUB } \\
\text { TOTAL } \\
========\end{array}$ & $=====$ & $\begin{array}{l}\text { NGENCY } \\
\text { TOTAL } \\
=======\end{array}$ & $\begin{array}{c}\text { SUB } \\
\text { TOTAL. } \\
==== \pm= \pm==\end{array}$ & $\begin{array}{c}\text { SITE } \\
\text { ALLOCAT ' N } \\
=== \pm====\end{array}$ & $\begin{array}{c}\text { TOTAL } \\
\text { DOLLARS } \\
========\end{array}$ \\
\hline $\begin{array}{r}1481470 \\
1632098 \\
4999996 \\
125637\end{array}$ & $\begin{array}{l}0.00 \\
0.00 \\
0.00 \\
0.00\end{array}$ & $\begin{array}{l}0 \\
0 \\
0 \\
0\end{array}$ & $\begin{array}{r}1481470 \\
1632098 \\
4999996 \\
125637\end{array}$ & $\begin{array}{r}95 \\
35 \\
100 \\
15\end{array}$ & $\begin{array}{r}1407397 \\
571234 \\
4999496 \\
18846\end{array}$ & $\begin{array}{r}2888867 \\
2203332 \\
9999492 \\
144483\end{array}$ & $\begin{array}{r}758616 \\
578595 \\
2625867 \\
37941\end{array}$ & $\begin{array}{r}3647483 \\
2781927 \\
12625359 \\
182424\end{array}$ \\
\hline 8239201 & 0.00 & 0 & 8239201 & 85 & 6996973 & 15236174 & 4001019 & 19237193 \\
\hline 2040481 & 0.00 & 0 & 2040481 & 40 & 816192 & 2856673 & 750162 & 3606835 \\
\hline 2040481 & 0.00 & 0 & 2040481 & 40 & 816192 & 2856673 & 750162 & 3606835 \\
\hline $\begin{array}{r}328856 \\
2358207\end{array}$ & $\begin{array}{l}0.00 \\
0.00\end{array}$ & $\begin{array}{l}0 \\
0\end{array}$ & $\begin{array}{r}328856 \\
2358207\end{array}$ & $\begin{array}{l}80 \\
25\end{array}$ & $\begin{array}{l}263085 \\
589552\end{array}$ & $\begin{array}{r}591941 \\
2947759\end{array}$ & $\begin{array}{l}756924 \\
781451\end{array}$ & $\begin{array}{r}748865 \\
3729210\end{array}$ \\
\hline 2687063 & 0.00 & 0 & 2687063 & 32 & 852637 & 3539700 & 938375 & 4478075 \\
\hline 12966745 & 0.00 & 0 & 12966745 & 67 & 8665802 & 21632547 & 5689556 & 27322103 \\
\hline 7813124 & 0.00 & 0 & 7813124 & 65 & 5078531 & 12891655 & 3385348 & 16277003 \\
\hline 7813124 & 0.00 & 0 & 7813124 & 65 & 5078531 & 12891655 & 3385348 & 16277003 \\
\hline $\begin{array}{r}42303 \\
115384 \\
41583 \\
816965 \\
183502 \\
194976\end{array}$ & $\begin{array}{l}0.00 \\
0.00 \\
0.00 \\
0.00 \\
0.00 \\
0.00\end{array}$ & $\begin{array}{l}0 \\
0 \\
0 \\
0 \\
0 \\
0\end{array}$ & $\begin{array}{r}42303 \\
115384 \\
41583 \\
816965 \\
183502 \\
194976\end{array}$ & $\begin{array}{l}75 \\
75 \\
75 \\
75 \\
75 \\
75\end{array}$ & $\begin{array}{r}31728 \\
86539 \\
31188 \\
612724 \\
137627 \\
146232\end{array}$ & $\begin{array}{r}74031 \\
201923 \\
72771 \\
1429689 \\
321129 \\
341208\end{array}$ & $\begin{array}{r}2202 \\
53198 \\
20403 \\
374714 \\
100468 \\
107345\end{array}$ & $\begin{array}{r}76233 \\
255121 \\
93174 \\
1804403 \\
421597 \\
448553\end{array}$ \\
\hline 1394713 & 0.00 & 0 & 1394713 & 75 & 1046038 & 2440751 & 658330 & 3099081 \\
\hline $\begin{array}{r}11116023 \\
205110 \\
1256124\end{array}$ & $\begin{array}{l}0.00 \\
0.00 \\
0.00\end{array}$ & $\begin{array}{l}0 \\
0 \\
0\end{array}$ & $\begin{array}{r}11116023 \\
205110 \\
1256124\end{array}$ & $\begin{array}{l}20 \\
25 \\
20\end{array}$ & $\begin{array}{r}2223204 \\
51278 \\
251225\end{array}$ & $\begin{array}{r}13339227 \\
256388 \\
1507349\end{array}$ & $\begin{array}{r}1027119 \\
19741 \\
116066\end{array}$ & $\begin{array}{r}14366346 \\
276129 \\
1623415\end{array}$ \\
\hline 12577257 & 0.00 & 0 & 12577257 & 20 & 2525707 & 15102964 & 1162926 & 16265890 \\
\hline
\end{tabular}


FLUOR DANIEL NORTHWEST, INC. COGEMA ENGINEERING CORP. JOB NO. Z466AAA3

FILE NO. Z466AAA3

WBS

DESCRIPTION

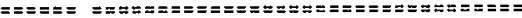

330200 SOIL DISPOSAL - TOP OF TANKS 330400 SOIL DISPOSAL - SURROUNDING TANKS 330500 DISPOSAL - TANK WALL DEBRIS

SUBTOTAL 33 DISPOSAL / BURIAL

SUBTOTAL 3

CONSTRUCTION

PROJECT TOTAL
* * IEST - INTERACTIVE ESTIMATING * * TANK REMOVAL

241-AX TANK FARM CLOSURE - PLANNING ESTIMATE PHMCROZ - WORK BREAKDOWN STRUCTURE (WBS) SUMMARY
PAGE $3 \quad$ OF 17

DATE $05 / 27 / 98 \quad 13: 37: 32$

BY

\begin{tabular}{|c|c|c|c|c|c|c|c|c|}
\hline $\begin{array}{l}\text { ESTIMATE } \\
\text { SUBTOTAL } \\
=\approx======\end{array}$ & $===$ & $\begin{array}{l}\text { ALATION } \\
\text { TOTAL } \\
========\end{array}$ & $==\begin{array}{c}\text { SUB } \\
\text { IOTAL } \\
= \pm \approx===\end{array}$ & $\begin{aligned} & \text { CONT } \\
\% & ==\end{aligned}$ & $\begin{array}{l}\text { INGENCY } \\
\text { TOTAL } \\
== \pm=====\end{array}$ & $\begin{array}{c}\text { SUB } \\
\text { TOTA } \mathrm{L} \\
\Rightarrow====\equiv=z\end{array}$ & $\begin{array}{c}\text { SITE } \\
\text { ALLOCAT'N } \\
=========\end{array}$ & $\begin{array}{c}\text { TOTAL } \\
\text { DOLLARS } \\
======= \pm=\end{array}$ \\
\hline $\begin{array}{r}1660500 \\
11688000 \\
254880\end{array}$ & $\begin{array}{l}0.00 \\
0.00 \\
0.00\end{array}$ & $\begin{array}{l}0 \\
0 \\
0\end{array}$ & $\begin{array}{r}1660500 \\
11688000 \\
254880\end{array}$ & $\begin{array}{l}35 \\
35 \\
35\end{array}$ & $\begin{array}{r}581175 \\
4090800 \\
89208\end{array}$ & $\begin{array}{r}2241675 \\
15778800 \\
344088\end{array}$ & $\begin{array}{l}0 \\
0 \\
0\end{array}$ & $\begin{array}{r}2241675 \\
15778800 \\
344088\end{array}$ \\
\hline 13603380 & 0.00 & 0 & 13603380 & 35 & 4761183 & 18364563 & 0 & 18364563 \\
\hline 27575350 & 0.00 & 0 & 27575350 & 30 & 8332928 & 35908278 & 1821256 & 37729534 \\
\hline
\end{tabular}


FLUOR DANIEL NORTHWEST, INC. COGEMA ENGINEERING CORP. JOB NO. 2466AAA3

FILE NO. Z466AAA3
** IEST - INTERACTIVE ESTIMATING ** TANK REMOVAL

241-AX TANK FARM CLOSURE - PLANNING ESTIMATE PHMCRO3 - ESTIMATE BASIS SHEET
PAGE 4 OF 17

DATE $05 / 27 / 98 \quad 10: 31: 25$

BY R.OHRT

1. ESTIMATE PURPOSE

THIS ESTIMATE HILL BE USED FOR A SCOPING STUDY.

:2. ESTIMATE TECHNICAL BASIS

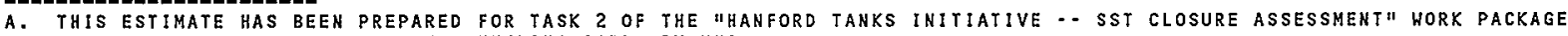
AWARDED TO SESC, NOW COGEMA ENGINEERING CORP. BY NHC.

B A DESCRIPTION OF THE TECHNICAL SCOPE OF HORK MAY BE FOUND IN THE FOLLOWING REFERENCE DOCUMENTS: ATTACHMENT - "SCOPE OF TECHNICAL SERVICES TO BE PROVIDED BY FLUOR DANIEL NORTHWEST" UNDATED. REQUEST FOR ESTIMATING SERVICES, DATED MARCH 19, 1997.

C. THE FOLLOWING CONSTRAINTS ANDIOR SPECIAL CONDITIONS EXIST:

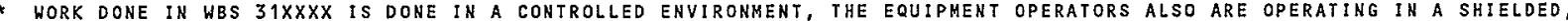

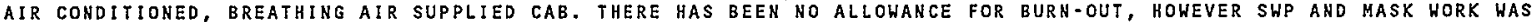
FACTORED ONTO THE PRODUCTIVITY RATES.

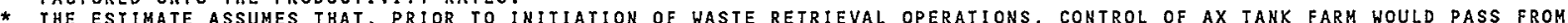
THE CURRENT OPERATIONS ACTIVITY TO A SEPARATE RETRIEVAL FUNCTION. AT COMPLETION OF RETRIEVAL, THE CONTROL. WOULD BE

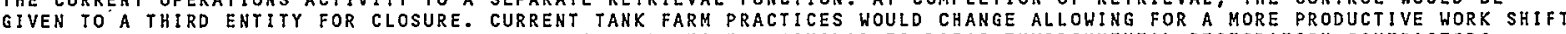
AND ALLOWING FOR MORE CONVENTIONAL CONSTRUCTION PRACTICES, SIMILAR TO DOEIS ENVIRONMENTAL RESTORATION CONTRACTORS. FOR FURTHER DESCRIPTIONS OF MAJOR ASSUMPTIONS AND CONCEPTS SEE THE COGEMA REPORT "COGEMA RPT25".

D. THIS ESTIMATE ORIGINALLY ISSUED 09/05/97 HAS BEEN UPDATED TO REFLECT LATEST LABOR RATES AND SITE ALLOCATIONS.

:3. ESTIMATE METHODOLOGY

A. DIRECT COSTS :

HISTORICAL DATA HAS BEEN USED WHERE JUDGED TO BE PRUDENT, EXPERT OPINION WAS UTILIZED WHEN OTHER METHODS WERE NOT

AVATLABLE AND A BOTTONS-UP APPROACH WAS USED WHEREVER POSSIBLE.

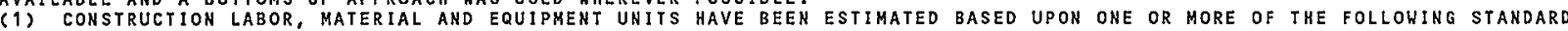
COMMERCIAL ESTIMAIING RESOURCES, PUBLISHED ESTIMATING MANUALS: R.S. MEANS AND RICHARDSON'S PROCESS PLANT CONTRUCTION ESTIMATING STANDARDS.

THE UNITS MAY HAVE BEEN FACTORED/ADJUSTED BY THE ESTIMATOR AS APPROPRIATE TO REFLECT INFLUENCES BY CONTRACT, WORK SITE, OR OTHER IDENTIFIED PROJECT OR SPECIAL CONDITIONS.

(2) FLUOR DANIEL HANFORD \& PROJECT HANFORD MANAGEMENT CONTRACT (PHMC) SUBCONTRACTOR DIRECT COSTS FOR

LOCKHEED MARTIN HANFORD CORP., NUMATEC HANFORD CORP. HAVE BEEN PROVIDED BY FDNW PROJECT MANAGEMENT FOR INCLUSION INTO THIS ESTIHATE.

B. DIRECT COST FACTORS

(1) SALES TAX HAS BEEN APPLIED TO ALL MATERIALS AND EQUIPMENT PURCHASES AT $8 \%$

(2) A FACTOR OF 15\% HAS BEEN APPLIED TO DIRECT CRAFT LABOR FOR GENERAL REQUIREMENTS; THIS INCLUDES HAULING NEN AND MATERIAL, CLEAN-UP AND LABOR SUPPORT AND QC INSPECTION. 
FLUOR DANIEL NORTHWEST, INC. COGENA. ENGINEERING CORP. JOS NO. 2466AAA3 FILE NO. Z466AAA3
* * IEST - INTERACTIVE ESTIMATING * *

TANK REMOVAL

241-AX TAHK FARM CLOSURE - PLANNING ESTIMATE PHMCRO3 - ESTIMATE BASIS SHEET
PAGE 5 OF 17

DATE $05 / 27 / 98 \quad 10: 31: 25$

BY R.OHRT

B. DIRECT COST FACTORS (CONT'D)

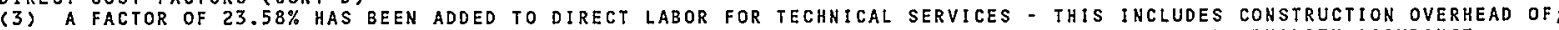
MANAGEMENT, SUPERINTENDENT, DOCUMENT CONTROL, TURNOVER, ENGINEERING, SURVEY AND CLERICAL; QUALITY ASSURANCE

ENGINEERING CONSTRUCTION SUPPORT AND PROJECT MANAGEMENT.

(4) CONSUMABLES ARE ESTIMATED AT $3.2 \%$ OF DIRECT CRAFT LABOR COSTS

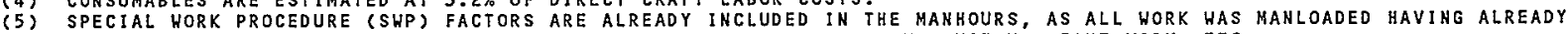
TAKEN INTO CONSIDERATION THE PRODUCTIVITY LOSSES DUE TO MASK WORK, SUIT UP, ZONE WORK, ETC.

(6) OVERTIME REQUIREMENTS AND SHIFT DIFFERENTIAL PAY FOR CRAFT LABOR ARE UNION NEGOTIATED UNDER THE HANFORD SITE STABILIZATION AGREEMENY. NO PREMIUM PAY WAS JUDGED TO BE NECESSARY FOR THIS HORK.

(7) GENERAL FOREMAN FACTOR OF 7\% HAS BEEN APPLIED TO DIRECT CRAFT LABOR CREWS.

(8) CONTRACT ADHINISTRATION FACTOR OF $18.75 \%$ HAS BEEN APPLIED TO THE DIRECT CONTRACT VALUE HHICH INCLUDES COSTS FOR BID PACKAGE PREPARATION, CONTRACT MANAGEMENT \& ADMINISTRATION AND PROJECT MANGEMENT \& PLANNING SUPPORT

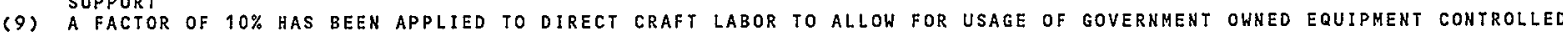
BY DYNCORP.

C. INDIRECT COSTS

FIXED PRICE CONTRACTOR OVERHEAD, PROFIT, BOND AND INSURANCE COSTS HAVE BEEN APPLIED ARE THE FOLLHOING PERCENTAGES:

LABOR $=25 \%$, EQUIPHENT USE $=25 \%$, MATERIAL $=25 \%$, SUBCONTRACT $=10 \%$, AND EQUIPMENT =25\%, AND ARE REFLECTED IN THE

"OH\&P/B\&I" COLUNN OF THE ESTIMATE DETAIL REPORT.

D. RATES

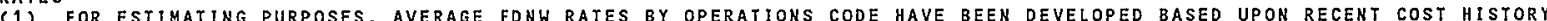
AND ADJUSTED TO REFLECT' INDUSTRY AVERAGE AE/CM RATES.

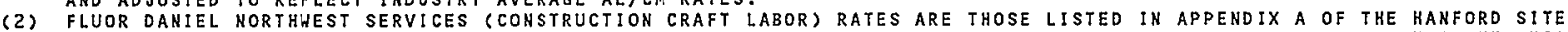

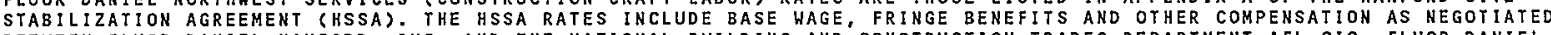

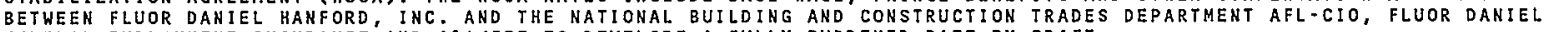
FEDERAL EMPLOYMENT INSURANCE AND G\&A/FEE TO DEVELOPE A FULLY BURDENED RATE BY CRAFT.

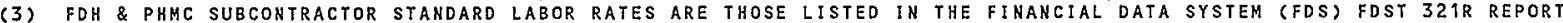
ORGANIZATION RATES PLUS ADDERS.

E. SITE ALLOCATIONS FACTORS

SITE ALLOCATION FACTORS ARE DEVELOPED AND PROVIDED BY FLUOR DANIEL HANFORD (FDH) FOR ESTIMATING USE.

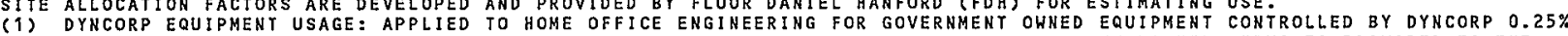

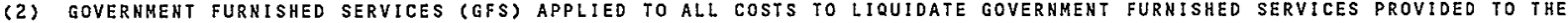
ENTERPRISE COMPANIES: $7 \%$ FOR FONH

(3) HANFORD SITE GENERAL AND ADMINISTRATIVE (G\&A): APPLIED TO ALL COSTS TO LIQUIDATE THE HANFORD GENERAL AND ADNINISTRATIVE SERVICES, $18.0 \%$

FDHW APPLIES THE ABOVE FACTORS TO ESTIMATED COSTS AS AS SHOWN IN THE PHMCROG REPORT.

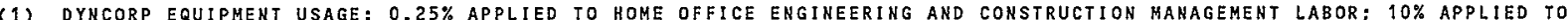
CONSTRUCIION LABOR.

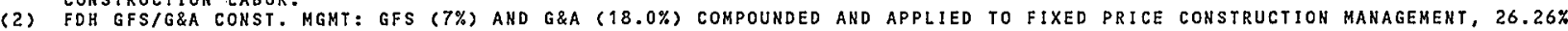

(3) FDH SUBCONTRACT: G\&A FEE (7.7\%) APPLIED TO FIXED PRICE CONTRACTS.

(4) FDH GFS/G\&A LABOR: GFS (7\%) AND G\&A (18\%) COMPOUNDED AND APPLIED TO HOME OFFICE ENGINEERING, CONSTRUCTION MANAGEMENT LABOR AND TO FDNHS CONSTRUCTION LABOR AT $26.26 \%$ 
FLUOR DANIEL NORTHWEST, INC. COGEMA ENGINEERING CORP. JOB NO. Z466AAA3

FILE NO. Z466AAA3

4. ESCALATION

ESCALATION PERCEHTAGES WERE NOT PROVIDED, ALL COSTS REFLECT CURRENT MAY 1998 PRICES.

5. CONTINGENCY

A. DEFINITION OF CONTINGENCY AS PROVIDED BY DOE

"CONTINGENCY COVERS COSTS THAT MAY RESULT FROM INCONPLETE DESIGN, UNFORESEEN AND UNPREDICTABLE CONDITIONS, OR UNCERTAINTIES WITHIN THE DEFINED PROJECT SCOPE. THE AMOUNT OF CONTINGENCY WILL DEPEND ON THE STATUS OF DESIGN,

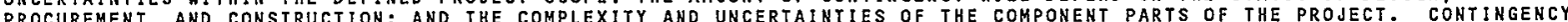

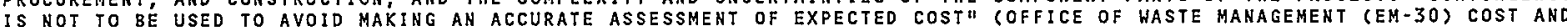
IS NOT TO BE USED

B. CONTINGENCY ALLOHANCE GUIDELINES

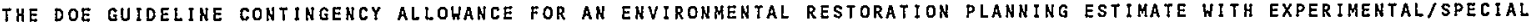
CONDITIONS $=$ UP TO $100 \%$

C. METHODOLOGY

CONTINGENCY IS EVALUATED AT THE LOWEST WORK BREAKDOWN STRUCTURE (WBS) LEVEL WITHIN THE COST ESTIMATE DETAILS. IT IS SUMMARIZED AT UPPER WBS LEVELS AND REPORTED ON THE SUMMARY REPORTS.

D. ANALYSIS

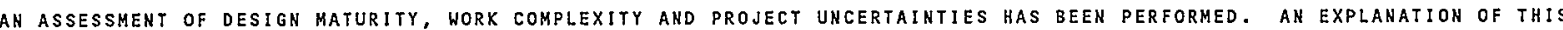
ASSESSMENT AND CONTINGENCY RATES WHICH HAVE BEEN ADDED TO THE COST OF WORK ARE AS FOLLOWS:

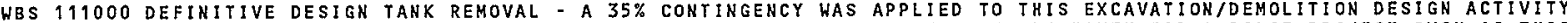

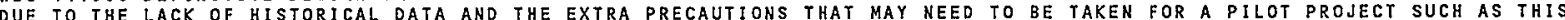
THAT HAS NO PRECEDENCE. *TOTAL CONTINGENCY $=95 \%$

WBS 112000 DEFINITIVE DESIGN OF BUILDING - A $25 \%$ CONTINGENCY WAS APPLIED HERE TO COVER POSSIBLE UNFORESEEN DESIGN

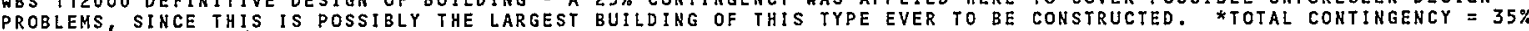

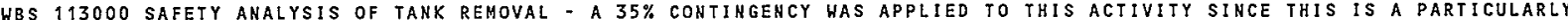
DIFFICULT COST TO PREDICT ESPECIALLY HAVING SUCH EXPERIMENTAL CONDITIONS. *TOTAL CONTINGENCY = 1OO\%

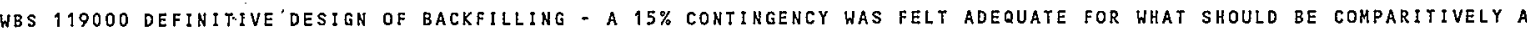
SIMPLE DESIGN. *TOTAL CONTINGENCY = $15 \%$

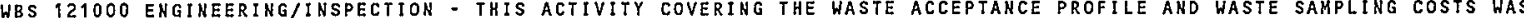

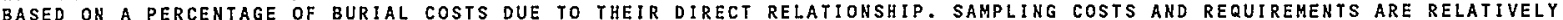
UNSTABLE SO A 25\% CONTINGENCY WAS DEEMED APPROPRIATE. * TOTAL CONTINGENCY = 40\% 
FLUOR DANIEL NORTHHEST, INC. COGEMA ENGINEERING CORP. JOB NO. 2466AAA3 FILE NO. 2466AAA3
* * IEST - INTERACTIVE ESTIMATING ** TANK REMOVAL

241-AX TANK FARM CLOSURE - PLANNING ESTIMATE PHMCRO3 - ESTIMATE BASIS SHEET
PAGE 7 OF 17

DATE $05 / 27 / 98 \quad 10: 31: 25$

BY R.OHRT

\section{ANALYSIS (CONTID)}

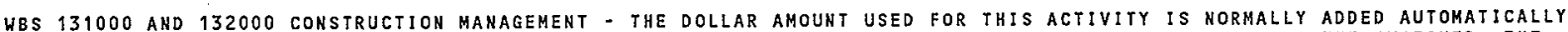

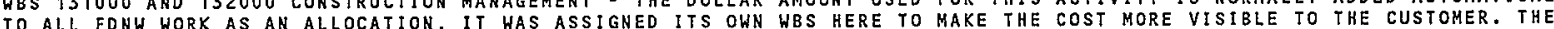
CONTINGENCIES APPLIED HERE ARE THE SAME AS WOULD HAVE BEEN APPLIED HAD CONSTRUCTION MANAGEHENT BEEN LEFT AS AN ALLOCATION TO THE RESPECTIVE CONSTRUCTION ACIIVITY, 30\% AND $20 \%$ *TOTAL CONTINGENCY = 8O\% AND $25 \%$

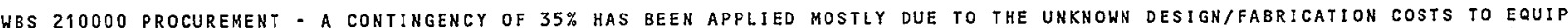

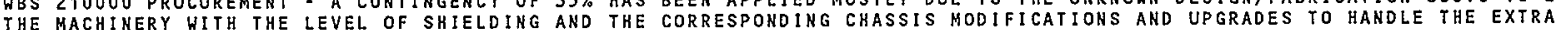
WEIGHT AND SPECIAL REQUIREMENTS FOR THIS ONE-OFF APPLICATION. *TOTAL CONTINGENCY = 65\%

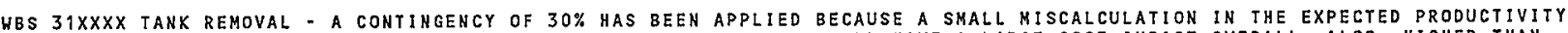

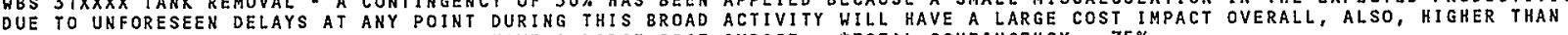
ANTICIPATED CONTAMINATJON LEVELS HILL HAVE A LARGE COST IMPACT. *TOTAL CONTINGENCY = 75\%

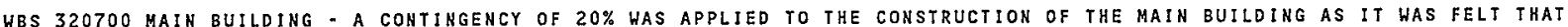

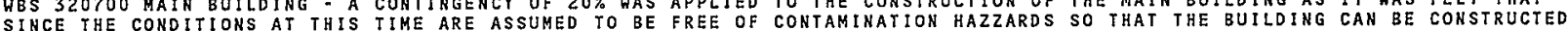
WITHOUT MAJOR COST DIFFERENCES FROM THAT OF NORMAL COMMERCIALLY CONSTRUCTED BUILDINGS OF THIS KIND.

*TOTAL CONTINGENCY = $20 \%$

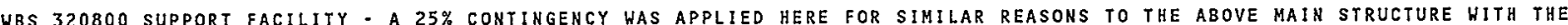
ADDITIONAL CUSHION GOR THE SPECIALIZED EQUIPMENT THAT HAS NOT YET BEEN FULLY REALIZED. *TOTAL CONTINGENCY = 25\%

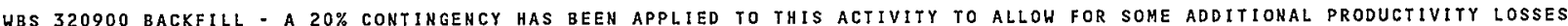

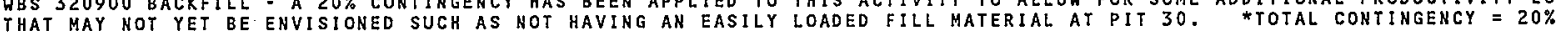

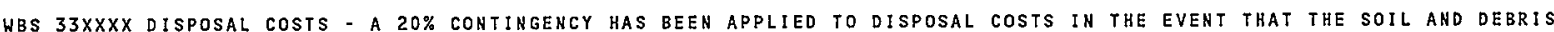

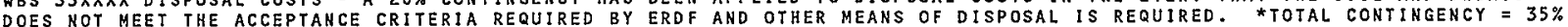

* E. PROGRAMATIC RISK (CONTINGENCY)

$=======Z==\pi========== \pm= \pm==$

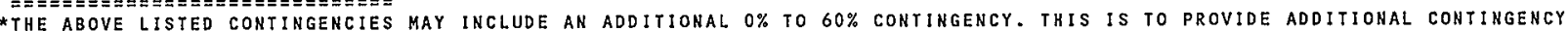

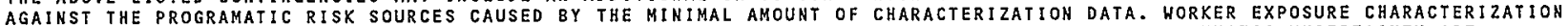

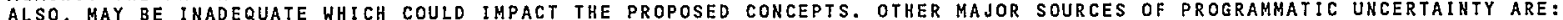

A) TANK WASTE RETRIEVAL MAY NOT HAVE ACHIEVED THE ASSUMED 1\% RESIDUAL INVENTORY TARGET, THIS WILL HAVE A TREMENDOUS COST INPACT ( $30 \%$ ALLOWANCE FOR WBS $111,113,131,21$ AND 31 )

B) LEAKAGE DURING RETRIEVAL COULD LEAD TO'SIGNIFICANTLY HIGHER LEVELS OF CONTANINATION IN THE SOIL (15\% CONTINGENCY ALLOWANCE FOR WBS $111,113,121,131,31$ AND 33 )

C) INDIRECT MANPOHEŔ COSTS MAY BE UNDERESTIMATED (5\% ALLOWANCE FOR CONSTRUCTION MANAGEMEMT)

D) SAR USQ COSTS MAY BE INSUFFICIENT (35\% ALLOWANCE FOR WBS 113 AND 10\% ALLOWANCE FOR WBS 112).

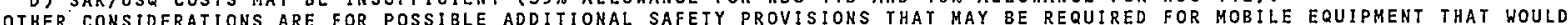
AFFECT EQUIPMENT CAPITAL COST AND/OR PROCUREMENT MPR. 
FLUOR DANIEL NORTHWEST, INC. COGEMA ENGINEERING CORṔ. JOB NO. 2466AAA3 FILE NO. Z466AAA3
** IEST - INTERACTIVE ESTIMATING ** TANK REMOVAL

241-AX TANK FARM CLOSURE - PLANNING ESTIMATE PHMCRO3 - ESTIMATE BASIS SHEET
PAGE 8 OF 17

DATE $05 / 27 / 98 \quad 10: 31: 25$

BY R.OHRT

6. ROUNDING

THE PROJECT COST SUMMARY REPORT IS SUMMARIZED AND ADJUSTED/ROUNDED AS FOLLOWS:

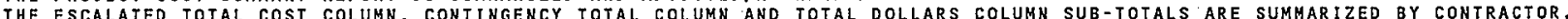
THE COLUMN SUBTOTALS ARE ADJUSTED/ROUNDED TO THE NEAREST \$1,0OO/\$10,OOO. THE PROJECT TOTAL SUMMARY LINE TOTALS ARE ADJUSTED/ROUNDED TO THE NEAREST $\$ 10,000 / \$ 100,000$.

\section{REMARKS}

MAJOR ASSUMPTIONS WHICH HAVE BEEN MADE IN THE PREPARATION OF THIS ESTIMATE ARE AS FOLLOWS:

A.) ALL ANCILLARY EQUIPMENT IS TO HAVE BEEN REMOVED PRIOR TO BEGINNING OF WORK.

B.) ALL EXCAVATION AND BACKFILL OPERATIONS ARE TO BE DONE HITH MACHIHES.

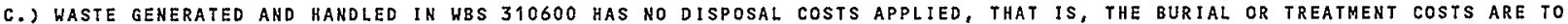
BE INCLUDED IN A PROCESS IMPACT STUDY.

D.) THE BUILDINGS ARE STILL EXISTING AT THE END OF THE JOB, COSTS HAVE NOT BEEN INCLUDED FOR DISMANTLING THE BUILDING.

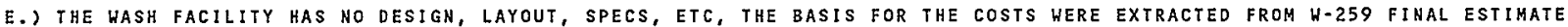
THAT HAD A SIMILAR FACILITY.

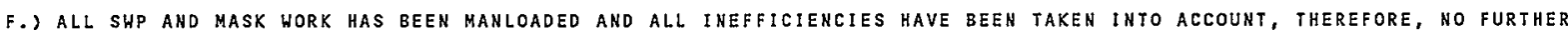
FACTORING PERCENTAGES WERE ADDED.

G.) BACKFILL MATERIALS ARE ASSUNED TO BE AVAILABLE AT PIT 30 , OR A SIMILAR DISTANCE.

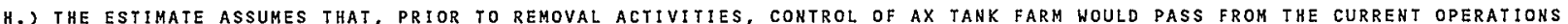

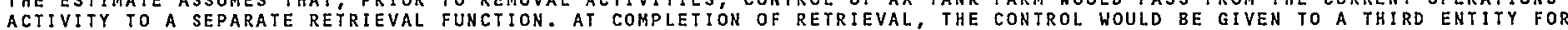
CLOSURE. CURRENT TANK FARM PRACTICES WOULD CHANGE ALLOWING FOR A MORE PRODUCTIVE WORK SHIFT AND ALLOWING FOR MORE

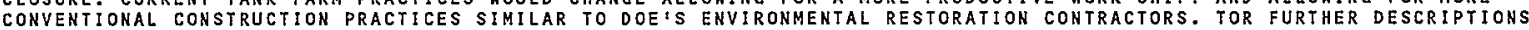
OF MAJOR ASSUMPTIONS AND CONCEPTS SEE THE COGEMA REPORT "COGEMA RPT25". 
FLUOR DANIEL NORTHUEST, INC. COGEMA ENGINEERING CORP.

JOB NO. Z466AAA3

FILE NO. Z466AAA3

SORT

CODE/WBS

DESCRIPTION

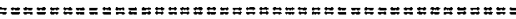

BHI

330200 SOIL DISPOSAL - TOP OF TANKS 330400 SOIL DISPOSAL - SURROUNDING TANK

330500 DISPOSAL - TANK WALL DEBRIS

SUBTOTAL 33 DISPOSAL / BURIAL

SUBTOTAL 3 CONSTRUCTION

TOTAL. BHI BECHTEL HANFORD INTERNATIONA 93603380

\section{ANK REMOVAL}

241-AX TANK FARM CLOSURE - PLANNING ESTIMATE

PHMCRO4 - COMPANY/HBS SUMMARY

$1660500 \quad 0.00$

$11688000 \quad 0.00$

$254880 \quad 0.00$

$13603380 \quad 0.00$

$13603380 \quad 0.00$

0.00

0 13603380

11688000

254880

13603380

$0 \quad 13603380$
PAGE 9 OF 17

DATE $05 / 27 / 98 \quad 13: 37: 37$

BY R.OHRT

\begin{tabular}{|c|c|c|c|c|c|c|c|}
\hline$A L$ & $\begin{array}{c}\text { ESCALATION } \\
\% \quad \text { TOTAL } \\
========\end{array}$ & $\begin{array}{c}\text { SUB } \\
\text { TOTAL } \\
== \pm= \pm= \pm==\end{array}$ & $==\begin{array}{c}C O N \\
\% \\
\%===\end{array}$ & $\begin{array}{c}\text { INGENCY } \\
\text { TOTAL } \\
==\approx====\end{array}$ & $\begin{array}{c}\text { SUB } \\
\operatorname{TOTAL} \\
==\approx \approx=\pi==\end{array}$ & $\begin{array}{c}\text { SITE } \\
\text { ALLOCAT'N } \\
========\end{array}$ & $\begin{array}{c}\text { TOIAL } \\
\text { DOLLARS } \\
=\approx=\approx \approx===\end{array}$ \\
\hline
\end{tabular}

18364563

$2358207 \quad 0.00$

SUBTOTAL

ENG INEER ING

290000 FDNW PROCUREMENT

SUBTOTAL 21 PROCUREMENT

310100 CDF FILL TANK BOTTOMS

390200 REMOVE SOIL ABOVE TANKS

310300 PULVERIZE TANK DOMES

310400 REMOVE SOIL AT. TAMK SIDES

310500 REMOVE TANK WALLS

310600 REMOVE TANK BOTTOMS

SUBTOTAL 31 FA CONSTT-ONSITE E/C

320700 MAIN BUILDING

320800 SUPPORT FACILITY
35

4761183

$328856 \quad 0.00$

$2687063 \quad 0.00$

$2687063 \quad 0.00$

\section{$0 \quad 1660500$}

2358207

80
25

2687063

2687063

7813124

$7813124 \quad 0.00$

$7813124 \quad 0.00$

7813124

39245

92450

32409

651312

160568

170513

160568

170513

0.00

0.00

$1146497 \quad 0.00$

11116023

205110
0.00

0.00
1146497

11116023 205110
328856
263085

589552

591941

2947759

3539700

3539700

12891655

12891655

5078531

29434
69338
24307
488484
120426
127885
859874

68679

161788

56716

1139796

280994

298398

2006371

2223204

51278
13339227
256388
156924

781451

938375

938375

3385348

3385348

2202
53198

20403

374714

100468

107345

658330

1027119
1974
2241675

15778800
344088

18364563

18364563

18364563

748865

3729210

4478075

4478075

16277003

16277003

7088

214986

77119

1514510

381462

405743

2664701

14366346 276129 
FLUOR DANIEL NORTHWEST, INC.

COGEMA ENGINEERING CORP.

JOB NO. 2466AAA3

FILE NO. Z466AAA3

SOR

CODE/WBS

DESCRIPTION

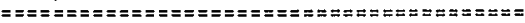

320900 BACKFILL

SUBTOTAL 32 - CONSTRUCTION-FIXED PRIC

SUBTOTAL 3 CONSTRUCTION

TOTAL FDNH FLUOR DANIEL NORTHHEST

LMHC LOCKHEED MARTIN HANFORD CORP.

111000 DEFINITIVE DESIGN - TANK REMOVAL

113000 SAFETY ANALYSIS

119000 DEFINITIVE DESIGN - BACKFILL

SUBTOTAL 11 DEFINITIVE DESIGN

121000 ENGR'G INSP - TANK REMOVAL

SUBTOTAL 12 ENGINEERING/INSPECTION

SUBTOTAL 1 ENGINEERING

310100 CDF FILL TANX BOTTOMS

310200 REMOVE SOIL ABOVE TANKS

310300 PULVERIZE TANK DOMES

310400 REMOVE SOIL AT TANK SIDES

310500 REMOVE TANK WALLS

310600 REMOVE TANK BOTTOMS

SUBTOTAL 31 FA CONST-ONSITE E/C

SUBTOTAL 3 CONSTRUCTION

TOTAL LMHC LOCKHEED MARTIN HANFORD COR 10527898
** IEST - INTERACTIVE ESTIMATING * * TANK REMOVAL

241-AX TANK FARM CLOSURE - PLANNING ESTIMATE PHMCRO4 - COMPANY/HBS SUMMARY

\section{ESTIMATE}

SUBTOTAL

= = $=\boldsymbol{=}=\mathbf{=}$

1256124 $\%$ TOTAL.

0.00

0.00

13723754

0.00

242239410.00

1481470

1632098

4999996

125637

0.00

0.00

0.00

0.00

8239201

0.00

2040481

0.00

2040481

0.00

10279682

0.00

3058
22934

9174

165653

22934

24463

248216

248216

0.00

0.00

0.00

0.00

0.00

0.00

0.00

0.00

0.00
TOTAL

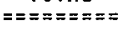

$==$

ONTINGENCY $===$ TOTAL.

10

1256124

20

0 12577257

o 13723754

$20 \quad 2525707$

$25 \quad 3385581$

o 24223941

38

125637

8239201

2040481

2040481

10279682

40

$$
3058
$$

22934

9174

165653

22934

24463

248216

248216

$0 \quad 10527898$ $\mathbf{z}=\mathbf{=}=$

251225

9316749

33540690

6144979

1407397

571234

4998496

18846

6996973

816192

816192

7813165

PAGE 10 OF 17

DATE $05 / 27 / 98 \quad 13: 37: 37$

BY R.OHRT

SUB
TOTAL
$== \pm== \pm=$

SITE
ALLOCAT I

ALLOCAT'N
$=======$

15102964

17109335

2888867

2203332

009492

144483

15236174

2856673

2856673

2294
17201

17201
6881

124240

17201

17201
18347

18092847

5352

40135

16055

289893

40135

42810

186164

434380

186164

434380

7999329

18527227
116066

1162926

1821256

39685669

75861

578595

2625867

37941

4001019

750162

750162

4751181

TOTAL.

DOLLARS

1623415

16265890

8930591

3647483

2781927

12625359

182424

19237193

3606835

3606835

22844028

5352

40135

16055

289893

40135

42810

434380

434380

4751181

23278408 
FLUOR DANIEL NORTHWEST, INC.

COGEMA ENGIHEERING CORP.

JOB NO. Z466AAA3

FILE NO. Z466AAA3

SORT

CODE/HBS DESCRIPTION

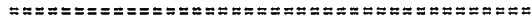

PROJECT TOTAL
* IEST - INTERACTIVE ESTIMATING **

TANK REMOVAL

241-AX TANK FARM CLOSURE - PLANNING ESTIMATE

PHMCRO 4 - COMPANY/WBS SUMMARY
PAGE 11 OF 17

DATE $05 / 27 / 98 \quad 13: 37: 37$

BY R.OHRT

\begin{tabular}{|c|c|c|c|c|c|c|}
\hline $\begin{array}{l}\text { ESTINATE } \\
\text { SUBTOTAL } \\
======\end{array}$ & $\begin{array}{c}\text { ESCALATION } \\
\% \text { TOTAL. } \\
====\Rightarrow====\Rightarrow\end{array}$ & $\begin{array}{c}\text { SUB } \\
\text { TOTAL } \\
==\approx====\end{array}$ & $\begin{array}{c}\text { CONTINGENCY } \\
\% \text { TOTAL } \\
====\quad \Rightarrow=\approx z==\pi=\end{array}$ & $\begin{array}{c}\text { SUB } \\
\text { TOTA } \\
====\equiv===\end{array}$ & $\begin{array}{c}\text { SITE } \\
\text { ALLOCAT'N } \\
===\approx====\end{array}$ & $\begin{array}{c}\text { TOTAL } \\
\text { DOLLARS } \\
==\equiv=\equiv=\approx=\end{array}$ \\
\hline$, 355,2$ & 0 & & $\frac{7}{6}$ & & & \\
\hline & 0.00 & $48,355,219$ & $22,077,26$ & & $10,896,160$ & \\
\hline
\end{tabular}


FLUOR DANIEL NORTHWEST, INC. COGEMA ENGINEERING CORP.

JOB NO. Z466AAA3

FILE NO. Z466AAA3

WBS

DESCRIPTION

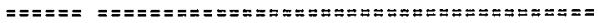

111000 DEFINITIVE DESIGH - TANK REMOVAL

12000 DEFINITIVE DESIGN - BUILDING

113000 SAFETY ANALYSIS

119000 DEFINITIVE DESIGN - BACKFILL

SUBTOTAL 11 DEFINITIVE DESIGN

121000 ENGR'G 1NSP - TANK REMOVAL

SUBTOTAL 12 ENGINEERING/INSPECTION

131000 CONSTRUCTION MANAGEMENT FOR CPAF 132000 CONSTRUCTION MANAGEMENT FOR F/P

\section{SUBTOTAL 13}

CONSTRUCTION MANAGEMENT

SUBTOTAL 1

ENGINEERING

\section{FDNH PROCUREMENT}

SUBTOTAL 21 PROCUREMEMT

10100 CDF FILL TANK BOTTOMS

310200 REMOVE SOIL ABOVE TANKS

310300 PULVERIZE TANK DOMES

310400 REMOVE SOIL AT TANK SIDES

310500 REMOVE TANK WALLS

310600 REMOVE TANK BOTTOMS

SUBTOTAL 31

FA CONST-ONSITE E/C

320700 MAIN BUILDING

320800 SUPPORT FACILITY 2 .

320900 BACKFILL

SUBTOTAL 32

CONSTRUCTION-FIXED PRICE
* * IEST - INTERACTIVE ESTIMATING * * TANK REMOVAL

241-AX TANK FARM CLOSURE - PLANNING ESTIMATE

PHMCRO5 - CONSTRUCTION MANAGEMENT/OTHER COST SUMMARY

\begin{tabular}{|c|c|c|c|}
\hline $\begin{array}{l}\text { ESTIMATE } \\
\text { SUBTOTAL } \\
======\end{array}$ & 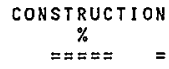 & $\begin{array}{l}\text { N MANAGEMENT } \\
\text { TOTAL } \\
=======\end{array}$ & $\begin{array}{r}\text { OTHER } \\
\text { COSTS } \\
======\end{array}$ \\
\hline $\begin{array}{r}1481470 \\
1632098 \\
4999996 \\
125637\end{array}$ & $\begin{array}{l}0.00 \\
0.00 \\
0.00 \\
0.00\end{array}$ & $\begin{array}{l}0 \\
0 \\
0 \\
0\end{array}$ & \\
\hline 8239201 & & 0 & \\
\hline 2040481 . & 0.00 & 0 & \\
\hline 10279682 & & 0 & \\
\hline $\begin{array}{r}328856 \\
2358207\end{array}$ & $\begin{array}{l}0.00 \\
0.00\end{array}$ & $\begin{array}{l}0 \\
0\end{array}$ & \\
\hline 12966745 & & 0 & \\
\hline 12966745 & & 0 & \\
\hline 7813124 & 0.00 & 0 & \\
\hline 7813124 & & 0 & \\
\hline $\begin{array}{r}42303 \\
115384 \\
41583 \\
816965 \\
183502 \\
194976\end{array}$ & $\begin{array}{l}0.00 \\
0.00 \\
0.00 \\
0.00 \\
0.00 \\
0.00\end{array}$ & $\begin{array}{l}0 \\
0 \\
0 \\
0 \\
0 \\
0\end{array}$ & \\
\hline 1394713 & & 0 & \\
\hline $\begin{array}{r}11196023 \\
205190 \\
1256124\end{array}$ & $\begin{array}{l}0.00 \\
0.00 \\
0.00\end{array}$ & $\begin{array}{l}0 \\
0 \\
0\end{array}$ & \\
\hline
\end{tabular}

PAGE 12 OF 17

DATE $05 / 27 / 98 \quad 13: 37: 41$

BY R.OHRT

$==\underset{\operatorname{TOTAL}}{\text { SUB }}$

TOTAL $\approx=\approx \approx= \pm=\mathbf{=}$

1481470

1632098

4999996

125637

8239201

2040481

10279682

328856

2358207

12966745

12966745

7813124

7813124

42303

115384

41583

816965

183502

194976

1394713

11116023

205110

1256124

13971970 
FLUOR DANIEL NORTHWEST, INC. COGEMA ENGINEER ING CORP. JOB NO. Z466AAA3

FILE NO. Z466AAA3

\section{WBS}

DESCRIPTION

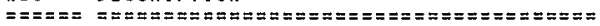

330200 SOIL DISPOSAL - TOP OF TANKS

330400 SOIL DISPOSAL - SURROUNDING TANKS

330500 DISPOSAL - TAHK WALL DEBRIS

SUBTOTAL 33 DISPOSAL / BURIAL

- ....

SUBTOTAL 12 ENGINEERING/INSPECTION

131000 CONSTRUCTION MANAGEMENT FOR CPAF 132000 CONSTRUCTION MANAGEMENT FOR F/P

\section{SUBTOTAL 13 \\ CONSTRUCTION MANAGEMENT}

SUBTOTAL 1

ENGINEERINO

\section{FDNH PROCUREMENT}

SUBTOTAL 21 PROCUREMENT

310100 CDF FILL TANK BOTTOMS

310200 REKOVE SOIL ABOVE TANKS

310300 PULVERIZE TANK DOMES

310400 REMOVE SOIL AT TANK SIDES

310500 REHOVE TANK WALLS

310600 REMOVE TANK BOTTOMS.

\section{SUBTOTAL 31 \\ FA CONST-ONSITE E/C}

320700 MAIN BUILDING

320800 SUPPORT FACILITY

320900 BACKFILL

SUBTOTAL 32

CONSTRUCTION-FIXED PRICE
* * IEST - INTERACTIVE ESTIMATING * * TANK REMOVAL

241-AX TANK EARM CLOSURE - PLANNING ESTIMATE

PHMCRO5 - CONSTRUCTION MANAGEMENT/OTHER COST SUMMARY
PAGE 13 OF 17

DATE $05 / 27 / 98 \quad 13: 37: 42$

BY R.OHRT
EST IMATE
SUBTOTAL

$==\boldsymbol{=}=\boldsymbol{=}=$

1660500

11688000

254880

27575350

(........

10279682

328856

2358207

12966745

12966745

7813124

7813124

42303

42303
115384

115384
41583

816965

183502

194976

1394713

11116023

205190

1256124

13971970

\section{CONSTRUCTION MANAGEMENT}

$$
\%==+ \text { TOTAL }
$$

$=\mathbf{=}=$

$==\boldsymbol{=}=\boldsymbol{=}=$

0.00
0.00

0.00
0.00

0
0
0

0.00

0.00
0.00

$======$

OTHER
COSTS
$=====$

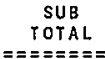

= $=$ ニ $=$ =

TOTAL $==+==+=$ =

1660500

11688000

254880

27575350

10279682

328856

2358207

12966745

12966745

7813124

7813124

0.00

0.00

0.00

0.00

0.00

0.00

$.00 \quad 0$

0

0

0

0

0

0

0$$
0
$$

0.00

0.00
0.00
0.00

0
0
0

0

\section{3}

115384

41583

816965

183502

194976

1394713

11116023

205110

1256124

13971970 
FLUOR DANIEL NORTHWEST, INC. COGEHA ENGINEERING CORP

JOB NO. Z466AAA3

FILE NO. Z466AAA3

WBS DESCRIPTION

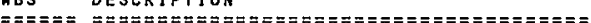

111000 DEFINITIVE DESIGN - TANK REMOVAL

112000 DEFINITIVE DESIGN - BUILDING

113000 SAFETY ANALYSIS

119000 DEFINITIVE DESIGN - BACKFILL

SUBTOTAL 11 DEFINITIVE DESIGH

121000 ENGRIG INSP - TANK REMOVAL

SUBTOTAL 12 ENGINEERING/INSPECTION

131000 CONSTRUCTION MANAGEMENT FOR CPAF

132000 CONSTRUCTION MANAGEMENT FOR F/P

\section{SUBTOTAL 13 CONSTRUCTION MANAGEMENT}

SUBTOTAL 1

EN G I NEER ING

210000 FDNW PROCUREMENT

SUBTOTAL 21 PROCUREMENT

310100 CDF FILL TANK BOTTOMS

310200 REMOVE SOIL ABOVE TANKS

310300 PULVERIZE TANK DOMES

310400 REMOVE SOIL AT TANK SIDES

310500 REMOVE TANK WALLS

310600 REHOVE TANK BOTTOMS

SUBTOTAL 31

FA CONST-ONSITE E/C

320700 MAIN BUILDING

320800 SUPPORT FACILITY

320900 BACKFILL

SUBTOTAL 32 CONSTRUCTION-FIXED PRICE
** IEST - INTERACTIVE ESTIMATING ** TANK REMOVAL

241-AX TANK FARM CLOSURE - PLANNING ESTIMATE

PHMCROG - SITE ALLOCATIONS BY WBS
PAGE 14 OF 17

DATE $05 / 27 / 98 \quad 13: 37: 10$

BY R.OHRT

\begin{tabular}{|c|c|c|c|c|c|c|}
\hline $\begin{array}{l}\text { ESTIMATE } \\
\text { SUBTOTAL } \\
=======\end{array}$ & $\begin{array}{c}\text { DYN } \\
\text { EQ. USAGE } \\
=======\end{array}$ & $\begin{array}{r}\text { FDH GFS/G\&A } \\
\text { CONST.MGMT } \\
========\end{array}$ & $\begin{array}{c}\text { FDH MPR } \\
\text { F.P. } / \mathrm{S} \cdot \mathrm{C} . \\
========\end{array}$ & $\begin{array}{c}\text { FDH GFS/G\&A } \\
\text { lABOR } \\
=========\end{array}$ & $\begin{array}{c}\text { FDH MPR/G\&A } \\
\text { MATERIAL } \\
=== \pm====\end{array}$ & $\begin{array}{l}\text { SITE ALLOC } \\
\text { SUBTOTAL } \\
========\end{array}$ \\
\hline $\begin{array}{r}1481470 \\
1632098 \\
4999996 \\
125637\end{array}$ & $\begin{array}{l}0 \\
0 \\
0 \\
0\end{array}$ & $\begin{array}{l}0 \\
0 \\
0 \\
0\end{array}$ & $\begin{array}{l}0 \\
0 \\
0 \\
0\end{array}$ & $\begin{array}{r}389034 \\
428589 \\
1312999 \\
32992\end{array}$ & $\begin{array}{l}0 \\
0 \\
0 \\
0\end{array}$ & $\begin{array}{r}389034 \\
428589 \\
1312999 \\
32992\end{array}$ \\
\hline 8239201 & 0 & 0 & 0 & 2163614 & 0 & 2163614 \\
\hline 2040481 & 0 & 0 & 0 & 535830 & 0 & 535830 \\
\hline 2040481 & 0 & 0 & 0 & 535830 & 0 & 535830 \\
\hline $\begin{array}{r}328856 \\
2358207\end{array}$ & $\begin{array}{r}822 \\
5896\end{array}$ & $\begin{array}{l}0 \\
0\end{array}$ & $\begin{array}{l}0 \\
0\end{array}$ & $\begin{array}{r}86358 \\
619265\end{array}$ & $\begin{array}{l}0 \\
0\end{array}$ & $\begin{array}{r}87180 \\
625161\end{array}$ \\
\hline 2687063 & 6718 & 0 & 0 & 705623 & 0 & 712341 \\
\hline 12966745 & 6718 & 0 & 0 & 3405067 & 0 & 3411785 \\
\hline 7813124 & 0 & 0 & 0 & 0 & 2051726 & 2051726 \\
\hline 7813124 & 0 & 0 & 0 & 0 & 2051726 & 2051726 \\
\hline $\begin{array}{r}42303 \\
115384 \\
41583 \\
816965 \\
183502 \\
194976\end{array}$ & $\begin{array}{r}340 \\
6122 \\
3148 \\
43088 \\
15245 \\
16563\end{array}$ & $\begin{array}{l}0 \\
0 \\
0 \\
0 \\
0 \\
0\end{array}$ & $\begin{array}{l}0 \\
0 \\
0 \\
0 \\
0 \\
0\end{array}$ & $\begin{array}{r}892 \\
16077 \\
8267 \\
113149 \\
40033 \\
43494\end{array}$ & $\begin{array}{r}26 \\
8200 \\
244 \\
57885 \\
2132 \\
1283\end{array}$ & $\begin{array}{r}1258 \\
30399 \\
11659 \\
214122 \\
57410 \\
61340\end{array}$ \\
\hline 1394713 & 84506 & 0 & 0 & 221912 & 69770 & 376188 \\
\hline $\begin{array}{r}11116023 \\
205110 \\
1256124\end{array}$ & $\begin{array}{l}0 \\
0 \\
0\end{array}$ & $\begin{array}{l}0 \\
0 \\
0\end{array}$ & $\begin{array}{r}855933 \\
15793 \\
96722\end{array}$ & $\begin{array}{l}0 \\
0 \\
0\end{array}$ & $\begin{array}{l}0 \\
0 \\
0\end{array}$ & $\begin{array}{r}855933 \\
15793 \\
96722\end{array}$ \\
\hline 12577257 & 0 & 0 & 968448 & 0 & 0 & 968448 \\
\hline
\end{tabular}


HNF-3378-Rev. 0

FLUOR DANIEL NORTHWEST, INC, COGEMA ENGINEERING CORP.

JOB NO. Z466AAA3

FILE NO. Z466AAA3

HBS DESCRIPTION

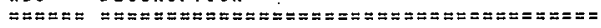

330200 SOIL DISPOSAL - TOP OF TANKS

330400 SOIL DISPOSAL - SURROUNDING TANKS

330500 DISPOSAL - TANK WALL DEBRIS

SUBTOTAL 33

DISPOSAL / BURIAL

SUBTOTAL 3

CONSTRUCTION
* * IEST - INTERACTIVE ESTIMATING ** TANK REMOVAL

241-AX TANK FARM CLOSURE - PLANNING ESTIMATE PHMCROG - SITE ALLOCATIONS BY HBS
PAGE 15 OF 17

DATE $05 / 27 / 98 \quad 13: 37: 11$

BY R.OHRT

PROJECT TOTAL

ESTIMATE

SUBTOTAL

$=\boldsymbol{=}=\boldsymbol{=}=\boldsymbol{=}=\mathbf{=}$

$\begin{array}{cc}\text { OYN } & \text { FDH GFS/G\&A } \\ \text { EQ.USAGE } & \text { CONST.MGMT }\end{array}$

$====\pi=$

$==\equiv \equiv \equiv \equiv \equiv$

FDH $M P R$ F.P./S.C.

FDH GFS /G\&A FOH LABOR

\section{FD MPR/G\&A} HATERIAL $\Rightarrow=\approx \equiv=\approx=\approx= \pm$

SITE ALLOC

$\begin{array}{rll}1660500 & 0 & 0 \\ 11688000 & 0 & 0 \\ 254880 & 0 & 0 \\ 13603380 & 0 & 0\end{array}$

0
0
0

27575350

84506

0

968448

0

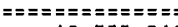

$48,355,219$

$=$

91,224

968,448

$3,626,979$

$2,121,496$ 
HNF-3378-Rev. 0

FLUOR DANIEL NORTHWEST, INC. COGEMA ENGINEERING CORP. JOB NO. Z466AAA3

FILE NO. Z466AAA3
* * IEST - INTERACTIVE ESTIMATING * * TANK REMOVAL

241-AX TANK FARM CLOSURE - PLANNING ESTIHATE PHHCRO7 - SITE ALLOCATION ESCALATION/CONTINGENCY REPORT $\begin{array}{ll}\text { PAGE } & 16 \text { OF } 17 \\ \text { DATE } & 05 / 27 / 98 \quad 13: 37: 46\end{array}$

BY R.OHRT
HBS DESCRIPTION

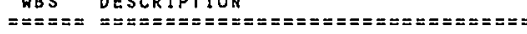

111000 DEFINITIVE DESIGN - TANK REMOVAL

112000 DEFINITIVE DESIGN - BUILDING

113000 SAFETY ANALYSIS

119000 DEFINITIVE DESIGN - BACKFILL

SUBTOTAL 11 DEFINITIVE DESIGN

121000 ENGR'G INSP - TANK REMOVAL

SUBTOTAL 12 ENGINEERING/INSPECTION

131000 CONSTRUCTION MANAGEMENT FOR CPAF

132000 CONSTRUCTION MANAGEMENT FOR F/P

SUBTOTAL 13 CONSTRUCTION MANAGEMENT

SUBTOTAL 1 ENGINEERING

290000 FDNH PROCUREMENT

SUBTOTAL 21 PROCURENENT

310100 CDF FILL TANK BOTTOHS

310200 REMOVE SOIL ABOVE TANKS

310300 PULVERIZE TANK DOMES

310400 REHOVE SOIL AT TANK SIDES

310500 REMOVE TANK WALLS

310600 REMOVE TANK BOTTOMS

SUBTOTAL 31 FA CONST-ONSITE E/C

320700 MAIN BUILOING

320800 SUPPORT FACILITY i.

320900 BACKFILL

SUBTOTAL 32 CONSTRUCTION-FIXED PRICE

\begin{tabular}{|c|c|c|}
\hline $\begin{array}{c}\text { S1TE ALLOC } \\
\text { SUB IOTAL } \\
========\end{array}$ & $==\stackrel{E S C A}{\%}=$ & $\begin{array}{l}\text { ALATION } \\
\quad \text { TOTAL } \\
======\end{array}$ \\
\hline $\begin{array}{r}389034 \\
428589 \\
1312999 \\
32992\end{array}$ & $\begin{array}{l}0.00 \\
0.00 \\
0.00 \\
0.00\end{array}$ & \\
\hline 2163614 & 0.00 & \\
\hline 535830 & 0.00 & \\
\hline 535830 & 0.00 & \\
\hline $\begin{array}{r}87180 \\
625161\end{array}$ & $\begin{array}{l}0.00 \\
0.00\end{array}$ & \\
\hline 712341 & 0.00 & \\
\hline 3411785 & 0.00 & \\
\hline 2051726 & 0.00 & \\
\hline 2051726 & 0.00 & \\
\hline $\begin{array}{r}1258 \\
30399 \\
11659 \\
214122 \\
57410 \\
61340\end{array}$ & $\begin{array}{l}0.00 \\
0.00 \\
0.00 \\
0.00 \\
0.00 \\
0.00\end{array}$ & \\
\hline 376188 & 0.00 & \\
\hline $\begin{array}{r}855933 \\
15793 \\
96722\end{array}$ & $\begin{array}{l}0.00 \\
0.00 \\
0.00\end{array}$ & \\
\hline 968448 & 0.00 & \\
\hline
\end{tabular}

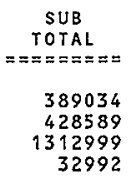

2163614

535830

535830

\section{0}

625161

712349

3411785

2051726

2051726

$\begin{array}{rl}\text { CONTINGENCY } \\ \%=\approx & \begin{array}{r}\text { TOTAL } \\ ======\end{array} \\ 95 & 369582 \\ 35 & 150006 \\ 100 & 1312868 \\ 15 & 4949\end{array}$

$85 \quad 1837405$

$40 \quad 214332$

$40 \quad 214332$

$80 \quad 69744$

156290

$32 \quad 226034$

$67 \quad 2277771$

$65 \quad 1333622$

$65 \quad 1333622$

TOTAL

DOLLARS

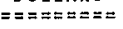

758616

578595

2625867

37941

4001019

750162

750162

156924

781451

938375

5689556

3385348

3385348

1258
30399
11659
214122
57410
61340

376188

855933

15793

968448

$\begin{array}{rrr}75 & 944 & 2202 \\ 75 & 22799 & 53198 \\ 75 & 8744 & 20403 \\ 75 & 160592 & 374714 \\ 75 & 43058 & 100468 \\ 75 & 46005 & 107345 \\ 75 & 282142 & 658330 \\ & & \\ 20 & 171186 & 1027119 \\ 25 & 3948 & 19741 \\ 20 & 19344 & 116066 \\ 20 & 194478 & 1962926\end{array}$


FLUOR DANIEL NORTHWEST, INC. COGEMA ENGINEERING CORP.

JOB HO. 2466AAA3

FILE NO. 2466AAA3

ACCOUNT

NUMBER DESCRIPTION. DEFINITIVE DESIGN - TANK REMOVAL

111000 TECHNICAL SERVICES

111000.00

111000.0001000 * DEFINITIVE DESIGN - REMOVAL $* * * * * * * * * * * * * * * * * * * * * * * * * * * *$

111000.0001005 DEFINITIVE DESIGN, $1-1 / 2 \quad 000$ MANYEAR

111000.0001010 PROCEDURES 4 MANYEARS

111000.0001020 AIR PERMITTING (ALLOWANCE)

111000.0001040 MOBILE EQUIPMENT SPECIFICATIONS AND DRAWINGS,

4 MANYEARS.

SUBTOTAL TECHNICAL SERVICES

TOTAL

\section{COST CODE 00000}

WBS 111000

(ESCALATION $0.00 \%$ - CONTINGENCY

000

000
000
* * IEST - INTERACTIVE ESTIMATING * * TANK REMOVAL

241-AX TANK FARM CLOSURE - PLANNING ESTIMATE

PHMCR08 - ESTIMATE DETAIL BY WBS / COST CODE $\begin{array}{lll}\text { PAGE } & 1 \\ \text { DATE } & 05 / 27 / 98 & 13: 37: 52\end{array}$

BY R.OHRT

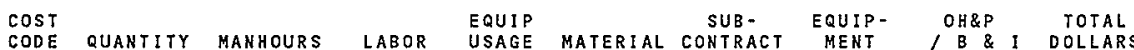

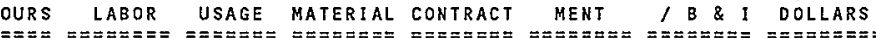

$\begin{array}{rrr}\text { L/S } & 0 & 0 \\ \mathrm{~L} / \mathrm{S} & 3120 & 194438 \\ \mathrm{~L} / \mathrm{S} & 8320 & 518502 \\ \mathrm{~L} / \mathrm{S} & 4012 & 250028 \\ \mathrm{~L} / \mathrm{S} & 8320 & 518502\end{array}$

0

0

0

0

0

0

194438

$8320 \quad 518502$

0
0
0
0

0

0

$0 \quad 518502$

$1 \mathrm{~L} / \mathrm{S}$

0
0
0

0
0
0

0

0

518502

23,772
$95.00 \%)$
$23,772,481,470$
$1,481,470$

0
$(95.00 \%$
$95.00 \%$

TOTAL WBS 111000 DEFINITIVE DESIGN - TANK REMOVAL

0

0

$\begin{array}{ccc}0 & & 0 \\ 0 & 0 & 1,481,470 \\ 0 & 0 & 0\end{array}$


HNF-3378-Rev. 0

FLUOR DANIEL NORTHWEST, INC.

COGEMA ENGINEERING CORP.

JOB NO. Z466AAA3

FILE NO. Z466AAA3

\section{ACCOUNT}

NUMBER

DESCRIPTION

$======\mathbf{=}=$

DEFINITIVE DESIGH - BUILDING

112000.00

TECHNICAL SERVICES

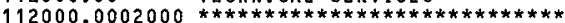
DEFINITIVE DESIGN - BUILDING $* * * * * * * * *$ AT $10 \%$ OF WBS $3207 \& 3208$

112000.0002010 SAFETY AHALYSIS OF HVAC ** IEST - INTERACTIVE ESTIMATING **
TANK REMOVAL.
249-AX TANK FARM CLOSURE - PLANNING ESTIMATE
PHMCRO8-ESTIMATE DETAIL BY WBS COST CODE

SUB-

$\begin{array}{lll}\text { PAGE } & 2 \\ \text { DATE } & 05 / 27 / 98 \quad 13: 37: 52\end{array}$

BY

R.OHRT
COST OODE QUANTITY MANHOURS LOUIP

CODE QUANTITY MANHOURS LABOR USAGE MATERIAL CONTRACT

SUB -

EQUIP- OH\&P TOTAL MENT $B$ OH\& I DOLLARS

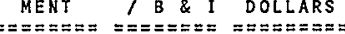

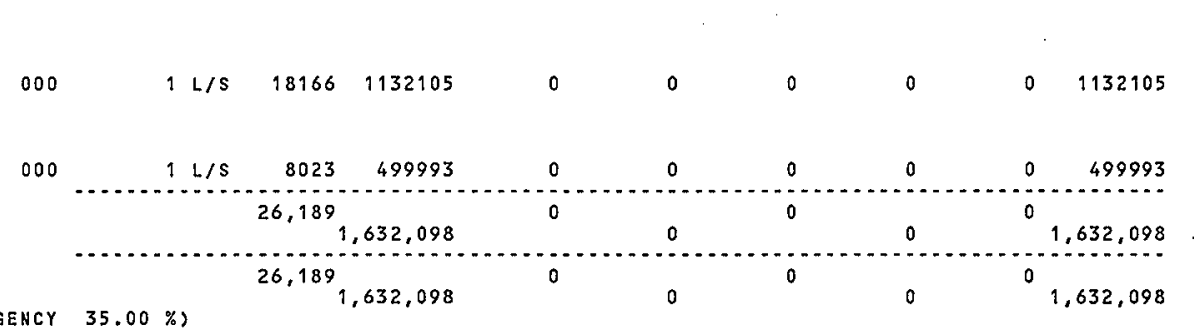

$35.00 \%$
TOTAL HBS 112000 DEFINITIVE DESIGN - BUILDING

\section{SUBTOTAL TECHNICAL SERVICES}

TOTAL

COST CODE 00000

CES 112000

$0.00 \%-$ CONTINGENCY

26,189

$1,632,098$

0
0

0

0

0 
HNF-3378-Rev. 0

FLUOR DANIEL NORTHWEST, INC. COGEHA ENGINEERING CORP.

JOB NO. Z466AAA3

FILE NO. 2466AAA3

ACCOUNT

NUMBER

DESCRIPTION

SAFETY ANALYSIS

113000

113000.00

TECHNICAL SERVICES

113000.0001030 SAFETY ANALYSIS/DOCUMENTATION (ALLOWANCE)

SUBTOTAL TECHNICAL SERVICES

TOTAL.

\section{COST CODE 00000}

WBS 113000

(ESCALATION

$0.00 \%-$ CONTINGENCY

000
* * IEST - INTERACTIVE ESTIMATING * * TANK REMOVAL

241-AX TANK FARM CLOSURE - PLANN ING ESTIMATE

PHMCR08 - ESTIMATE DETAIL BY HBS/ COST CODE
PAGE 3

DATE $\quad 05 / 27 / 98 \quad 13: 37: 52$

BY R.OHRT

COST EQUIP SUB- EQUIP- OH\&P TOTAL

CODE QUANTITY MANHOURS LABOR USAGE MATERIAL CONTRACT MENT / B \& I DOLLARS

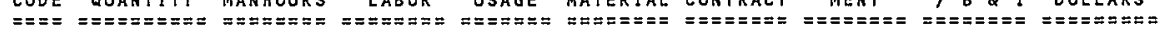

1 L/S $80231 \quad 4999996$

0

0

0

0

4999996

80,23

0

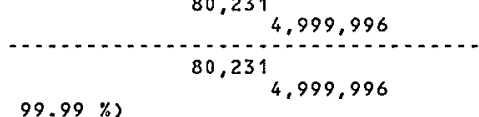

0

$4,999,996$

$99.99 \%$

80,231

$4,999,996$
0
0

TOTAL WBS 113000 SAFETY ANALYSIS

80,231
$4,999,996$


HNF-3378-Rev. 0

FLUOR DANIEL NORTHWEST, INC.

COGEMA ENGINEERING CORP.

JOB NO. Z466AAA3

FILE NO. Z466AAA3

\section{A.CCOUNT}

NUMBER DESCRIPTION TANK REMOVAL

249-AX TANK FARM CLOSURE - PLANNING ESTIMATE

PHMCRO 8 - ESTIMATE DETAIL BY HBS / COST CODE

CODE QUANTITY MANHOURS LABOR UQUIP

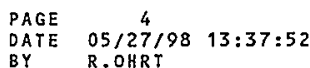

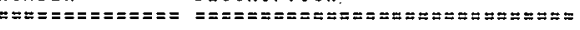

EQUIP-

MENT

OH\&P

B \& TOTAL

MATERIAL CONTRACT

119000

DEFINITIVE DESIGN - BACKFILL

119000.00

TECHNICAL SERVICES

$119000.0002000 * * * * * * * * * * * * * * * * * * * * * * * * * * * *$ DEFINITIVE DESIGN - BACKFILL

000

$1 \mathrm{l} / \mathrm{s}$

$2016 \quad 125637$

0

0

0

0

0

125637

AT $10 \%$ OF WBS 320900

\section{SUBTOTAL TECHNICAL SERVICES}

TOTAL

COST CODE 00000

HBS 199000

(ESCALATION

$0.00 \%$ - CONTINGENCY

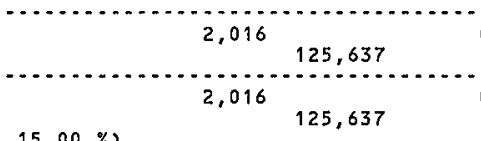

\section{0}

................

TOTAL WBS 119000 DEFINITIVE DESIGN - BACKFILL

\section{2,016}

0

125,637

0

$0^{2}$

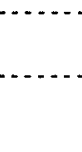

0

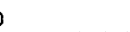

125,637

$0 \quad 125,637$

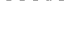

125,637 
HNF-3378-Rev, 0

FLUOR DANIEL NORTHWEST, INC. COGEMA ENGINEERING CORP.

JOB NO. Z466AAA3

FILE NO. Z466AAA3

\section{ACCOUNT}

NUMBER

DESCRIPTION

* IEST - INTERACTIVE ESTIMATING ** TANK REMOVAL

241-AX TANK FARM CLOSURE - PLANNING ESTIMATE PHMCRO8 - ESTIMATE DETAIL BY WBS / COST CODE

\section{$\begin{array}{lc}\text { PAGE } & 5 \\ \text { DAIE } & 05 / 27 / 98 \quad 13: 37: 52\end{array}$}

121000

ENGR'G INSP - TANK REMOVAL

121000.00 TECHNICAL SERVICES

$121000.0002000 * * * * * * * * * * * * * * * * * * * * * * * * * * * * \quad 000$ E \& I DURING CONSTRUCTIOH $* * * * * * * * * * * * * * * * * * * * * * * * * * * *$

121000.0002010 WASTE ACCEPTANCE PROFILE, AT $5 \%$ OF WBS 33 .

121000.0002020 WASTE SAMPLING. AT $10 \%$ OF WBS 33 .

COST
CODE QUANTITY MANHOURS LABOR UQUTP

EQUIP- OH\&P TOTAL MENT IB\& \& DOLLARS

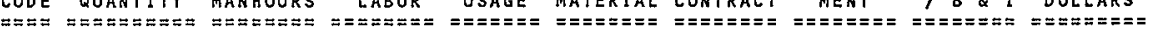

SUBTOTAL TECHNICAL SERVICES

TOTAL $\quad$ COST CODE 00000

WBS 121000

(ESCALATION

$0.00 \%$ - CONTINGENCY

000

000

0

0

0

0

0

0

0

0

0

$\begin{array}{llllllll}1 \mathrm{~L} / \mathrm{S} & 10914 & 680160 & 0 & 0 & 0 & 0 & 0 \\ 1 \mathrm{~L} / \mathrm{s} & 21828 & 1360321 & 0 & 0 & 0 & 0 & 0\end{array}$

s

32,742
$2,040,481$
$40.00 \%)$
32,742
$2,040,481$

$-\cdots$

0

$+-$

0

-...

1360321

0

0

0

0

0

0
2,0
$2,040,481$

0

$2,040,481$

TOTAL WBS 121000 ENGR'G INSP - TANK REMOVAL

\section{2,742}

$2,040,481$
0
0
0
0
0

$2,040,481$ 
HNF-3378-Rev. 0

FLUOR DANIEL NORTHWEST, INC.

COGEMA ENGINEERING CORP.

JOB NO. 2466 AAA3

FILE NO. Z466AAA3

ACCOUNT

NUHBER

DESCR IPTION TANK REMOVAL

241-AX TANK FARM CLOSURE - PLANNING ESTIMATE PHMCRO8 - ESTIMATE DETAIL BY WBS / COST CODE

COST

$\cos$

QUANTITY MANHOURS LABOR USAGE

SUB -

MATERIAL CONTRACT

$\begin{array}{lcc}\text { PAGE } & 6 & \\ \text { DATE } & 05 / 27 / 98 & 13: 37: 52\end{array}$

BY

R. OHRT

131000

CONSTRUCTION MANAGEMENT FOR CPAF

131000.00 TECHNICAL SERVICES

$131000.0001000 * * * * * * * * * * * * * * * * * * * * * * * * * * * * \quad 000$ CONSTRUCTION MANAGEHENT $* * * * * * * * * * * * * * * * * * * * * * * * * * * *$ AT $23.58 \%$ OF WBS 310

131000.0001002 THIS PERCENTAGE IS CURRENTLY 000 APPLIED TO ALL FDNWS CRAFT LABOR AS AN ALLOCATION.

SUBTOTAL

TECHNICAL SERVICES

TOTAL

COST CODE 00000

HBS 131000 (ESCALATION

$0.00 \%$ - CONTIHGENCY

1 L/S $\quad 5470 \quad 328856$

0

32885

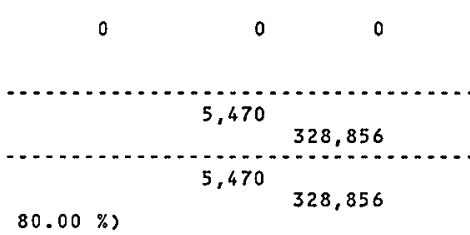

0

0

0

0

0

0

0

0

328,856

0

0

0

0

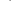

0

0

328,856

TOTAL WBS 131000 CONSTRUCTION MANAGEMENT FOR CPAF

5,470

328,856

0

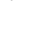

0

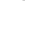

0

328,856 
FLUOR DANIEL NORTHWEST, INC. COGEMA ENGINEERING CORP.

JOB NO. Z466AAA3

FILE NO. Z466AAA3
* IEST - INTERACTIVE ESTIMATING ** TANK REMOVAL

241-AX TANK FARM CLOSURE - PLANNING ESTIMATE PHMCROB - ESTIMATE DETAIL BY WBS/ COST CODE $\begin{array}{lcl}\text { PAGE } & 7 \\ \text { DATE } & 05 / 27 / 98 & 13: 37: 52\end{array}$

BY R.OHRT

\begin{tabular}{|c|c|c|c|c|c|c|c|c|c|c|c|}
\hline $\begin{array}{l}\text { ACCOUNT } \\
\text { NUMBER } \\
===\approx=========\end{array}$ & 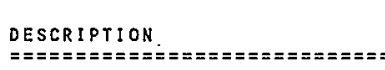 & $\begin{aligned} & \operatorname{COST} \\
& \operatorname{CODE} \\
&====\end{aligned}$ & $\begin{array}{l}\text { QUANTITY } \\
======= \pm==\end{array}$ & $\begin{array}{l}\text { MANHOURS } \\
==\approx=\equiv=\approx\end{array}$ & $\begin{aligned} & \operatorname{LABOR} \\
== \pm==== & ==\end{aligned}$ & $\begin{array}{l}\text { EQUIP } \\
\text { USAGE } \\
====\approx=\end{array}$ & $\begin{array}{l}\text { MATERIAL } \\
\Rightarrow=\approx====\end{array}$ & $\begin{array}{l}\text { SUB- } \\
\text { CONTRACT } \\
=======\end{array}$ & $\begin{array}{l}\text { EQU1P- } \\
\text { MENT } \\
=======\end{array}$ & $\begin{array}{c}\text { OH\&P } \\
\text { B \& I } \\
========\end{array}$ & $\begin{array}{c}\text { TOTAL } \\
\text { DOLLARS } \\
========\end{array}$ \\
\hline 132000 & CONSTRUCTION MANAGEMENT FOR & $F / P$ & & & & & & & & & . \\
\hline $\begin{array}{l}132000.00 \\
132000.0001000\end{array}$ & 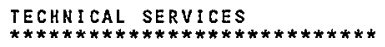 & 000 & $1 \mathrm{~L} / \mathrm{S}$ & 39225 & 2358207 & 0 & 0 & 0 & 0 & 0 & 2358207 \\
\hline & $\begin{array}{l}\text { CONSTRUCTION MANAGEMENT } \\
* * * * * * * * * * * * * * * * * * * * * * * * * * * * *\end{array}$ & & & & & & & & & & \\
\hline 132000.0001002 & $\begin{array}{l}\text { AT } 18.75 \% \text { OF WBS } 320 \\
\text { THIS PERCENTAGE IS CURRENTLY } \\
\text { APPLIED TO FIXED PRICE LABOR } \\
\text { AS AN ALLOCATION TO ALL JOBS } \\
\text { GREATER THAN \$5 MILLION. }\end{array}$ & 000 & 0 & . & 0 & 0 & 0 & 0 & 0 & 0 & 0 \\
\hline SUBTOTAL & TECHNICAL SERVICES & & & 39.225 & $2,358,207$ & 0 & 0 & 0 & 0 & 0 & $2,358,207$ \\
\hline TOTAL & $\begin{array}{l}\text { COST CODE } 00000 \\
\text { WBS } 132000 \\
\text { CESCALATION } 0.00 \%=\text { CONTINO }\end{array}$ & GENCY & $25.00 \%$ & 39.225 & $2,358,207$ & 0 & 0 & 0 & 0 & 0 & $2,358,207$ \\
\hline
\end{tabular}

TOTAL HBS 132000 CONSTRUCTION MANAGEMENT FOR F/P

39,225

$2,358,207$

0

0

0

0

$2,358,207$ 
FLUOR DANIEL. NORTHHEST, INC. COGEMA ENGINEERING CORP.

JOB NO. Z466AAA3

FILE NO. Z466AAA3
* * IEST - INTERACTIVE ESTIMATING ** TANK REMOVAL

241-AX TANK FARM CLOSURE - PLANNING ESTIMATE PHMCROS - ESTIMATE DETAIL BY WBS / COST CODE

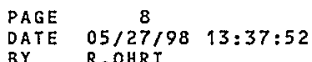

\begin{tabular}{|c|c|c|c|c|c|c|c|c|c|c|}
\hline $\begin{array}{l}\text { ACCOUNT } \\
\text { NUMBER } \\
============\end{array}$ & $\begin{array}{l}\text { DESCRIPIION } \\
=========================\end{array}$ & $\begin{array}{l}\operatorname{COST} \\
\operatorname{CODE} \\
====\end{array}$ & $\begin{array}{l}\text { QUANTI IY } \\
======= \pm=\end{array}$ & $\begin{array}{l}\text { MANHOURS } \\
=\approx====\approx\end{array}$ & $\begin{array}{c}\text { LABOR } \\
z=\approx=====\end{array}$ & $\begin{array}{l}\text { EQUIP } \\
\text { USAGE } \\
=======\end{array}$ & $\begin{array}{l}\text { MATERIAL } \\
=======\end{array}$ & $\begin{array}{l}\text { SUB - } \\
\text { CONIRACT } \\
\Rightarrow=\approx==\approx==\end{array}$ & $\begin{array}{c}\text { EQUIP- } \\
\text { MENT } \\
===\approx====\end{array}$ & $\begin{array}{cc}\text { OH\&P } & \text { TOTAL. } \\
\text { B B \& I } & \text { DOLLARS } \\
====\approx== & ========\end{array}$ \\
\hline
\end{tabular}

210000

FDNW PROCUREMENT

210000.01

GENERAL REQUIRMENTS

$210000.0101000 * * * * * * * * * * * * * * * * * * * * * * * * * * * * \quad 460$ EQUIPMENT PROCUREMENT

460

0

0

0

0

0

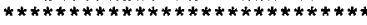

10000.0101002 CATERPILLAR 375

01002 CATERPILLAR 375
01004 HYDRAULIC CIRCUIT OPTION 460

210000.0101

ELEVATED CAB $(5,-11$ it)

SHIELDED CAB (ALLOWANCE) LEAD GLASS $31 \times 5: X$ 6" W/FRAME.

STEEL PLATE, 6" THICK, 460

54,000 LB PER CAB, FABRICATED O $\$ 4 / L B$

210000.0101015

2 EA

2 EA

0

2 EA

1628000

30680

46800

400000

2 EA

432000

1 EA

1 EA

750000

FILAR D 10 BULLDOZER
IELDED CAB (ALLOWANCE)

460

210000.0101020
210000.0101024

LEAD GLASS, $31 \times 51 \times$

6II W/FRAME.

STEEL PLATE, 6" THICK, 460

54,000 LB PER CAB

210000.0901026 FABRICATED a $\$ 4 / L B$

210000.0101050 UP-70 BASE UNIT

210000.0101052 SHEAR JAW

210000.0101054

210000.0101056

210000.0101072 COUPLERS

210000.0101110 CATERPILLAR 988 WHEEL LOADER

210000.0101114

SHIELDED CAB (ALLOWANCE?

LEAD GLASS, $31 \times 51 \times$

6" W/FRAME.

STEEL PLATE, 6" THICK, 460

54,000 LB PER CAB

210000.0101116 FABRICATED a $\$ 4 / \mathrm{LB}$

210000.0101150 .TRUCKS

210000.0101152 SHIELDED CABS, 3" THICK

460

$1 \mathrm{EA}$

200000

216000

2 EA

1 EA

1 EA

2 EA

$\begin{array}{ll}5 & E A \\ 1 & E A\end{array}$

0

1 EA

1 EA

5 EA

STEEL AT SIDES, 1 It AT

FRONT, FLOOR, ROOF AND

FIREWALL, 4" AI BACK.

STEEL;, FABBED a $13,000460 \quad 65000$ LB

LB PER CAB.

0

0

0260000

0

45000

33000

99000

11400

565000

200000

216000

450000

273000 
FLUOR DANIEL NORTHWEST, INC. COGEHA ENGINEERING CORP.

JOB NO. 2466AAA3

FILE NO. 2466AAA3

\section{ACCOUNT}

NUHBER

DESCRIPTION

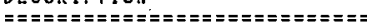

210000.0101156

210000.0101158

LEADED GLASS ( 21 SF

PER (AB)

UPGRADED SUSPENSION (ALLOWANCE)

210000.0101160 TRAILER, ROLL-ON ROLL-OFF

SUBTOTAL GENERAL REQUIRMENTS

SALES TAX $8.00 \%$ OH\&P (ON MARKUPS ONLY)

TOTAL

\section{COST CODE 46001}

WBS 210000

(ESCALATION

$0.00 \%-$ CONTINGENCY
* IEST - INTERACTIVE ESTIMATING ** TANK REMOVAL.

241-AX TANK FARM CLOSURE - PLANNING ESTIMATE PHMCR08 - ESTIMATE DETAIL BY HBS / COST CODE $\begin{array}{lll}\text { PAGE } & 9 \\ \text { DATE } & 05 / 27 / 98 & 13: 37: 53\end{array}$

BY R.OHRT
COST
CODE QUANTITY MANHOURS LABOR UQUIP
USAG MATERIAL CONTRACT MUIP-

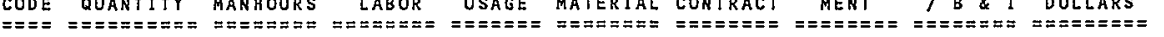

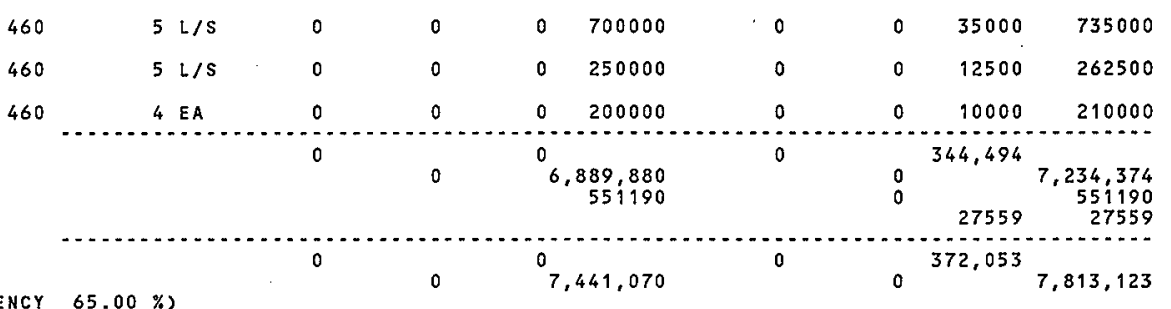

TOTAL WBS 210000 FDNW PROCUREMENT
0
${ }^{7}$

$7,441,070$
0
0

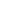

$0 \quad 372,0537,813,123$ 
FLUOR DANIEL NORTHHEST, INC. COGEMA ENGINEERING CORP. JOB HO. Z466AAA3 FILE NO, Z466AAA3
* * IEST - INTERACTIVE ESTIMATING * * TANK REMOVAL

249-AX TANK FARM CLOSURE - PLANNING ESTIMATE PHMCRO8 - ESTIMATE DETAIL BY WBS/ COST CODE

\section{$\begin{array}{lcl}\text { PAGE } & 10 \\ \text { OATE } & 05 / 27 / 98 & 13: 37: 53\end{array}$ \\ BY R.OHRT}

ACCOUNT
NUMBER
DESCRIPTION

$\cos$

EQUI

EQUIP SUB -

EQUIP-

EQUIP- OH\&P TOTAL
MENT CDF FILL TANK BOTTOMS

GENERAL REQUIRMENTS

310100.01

$310100.0101000 * * * * * * * * * * * * * * * * * * * * * * * * * * * * \quad 460$ HPT'S

$* * * * * * * * * * *$

2 NEN FOR 4 DAYS

SUBTOTAL GENERAL REQUIRMENTS

TOTAL COST CODE 46001

WBS 310100

(ESCALATION

$0.00 \%-$ CONTINGENCY

310100.02

310100.0201000 CDF FILL TANK BOTTOMS

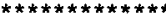

310100.0201002 UTILIZING TREMMIES, FILL EACH TANK WITH 12 " OF CONTROLLED DENSITY FILL. LABORERS, 2 MEN $X 4$ DAYS FLAGGER; 1 MAN $X 4$ DAYS 42 METER BOOM PUMP W/OPER. MOB /DEMOB . OPERATOR \& PUMP 4 DAYS PLUS $\$ 2.75 / C Y$

CLASS A CDF (100 PSI)

SUBTOTAL SITEHORK

CONSUHABLES $\quad 3.20 \%$

GENERAL FOREMAN $7.00 \%$

GEHERAL REQUIREMENTS $15.00 \%$

SALES TAX 8.00\%

DH\&P (ON MARKUPS ONLY)

TOTAL

COST CODE 46002

WBS 310100

SESCALATION $0.00 \%$ - CONTINGENCY $75.00 \%$

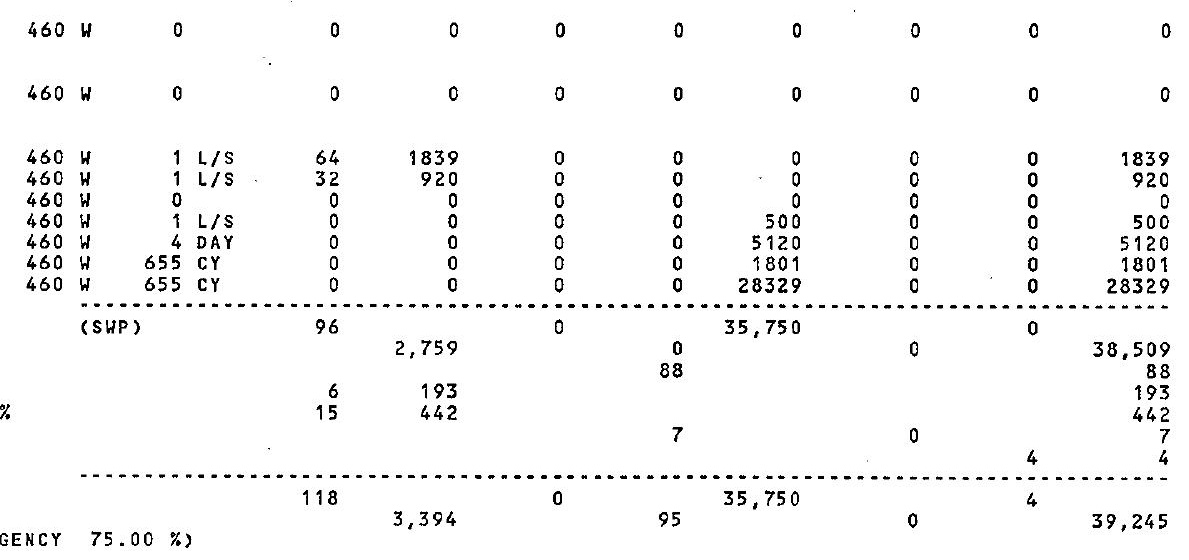

3,058


HNF-3378-Rev. 0

FLUOR DANIEL NORTHHEST, INC.

COGEMA ENGINEERING CORP.

JOB NO. Z466AAA3

FILE NO. Z466AAA3

\section{ACCOUNT}

NUMBER

DESCRIPTION

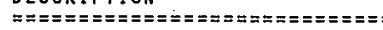

TOTAL WBS 310100 CDF FILL. TANK BOTTONS

\section{* * IEST - INTERACTIVE ESTIMATING * TANK REMOVAL}

241-AX TANK FARM CLOSURE - PLANNING ESTIMATE PHMCRO8 - ESTIMATE DETAIL BY WBS/ COST CODE

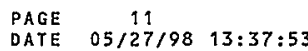

BY R.OHRT

\begin{tabular}{|c|c|c|c|c|c|c|c|c|c|}
\hline \multirow[t]{3}{*}{$\begin{array}{l}\operatorname{COST} \\
\operatorname{CODE} \\
====\end{array}$} & \multirow[t]{3}{*}{$=\begin{array}{c}\text { QUANTITY } \\
=\approx========\end{array}$} & \multirow{3}{*}{$\begin{array}{l}\text { MANHOURS } \\
====== \\
182\end{array}$} & \multirow{3}{*}{ 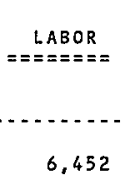 } & \multirow{3}{*}{ 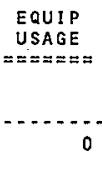 } & \multicolumn{2}{|c|}{$\begin{array}{lc}\text { SUTERIAL } & \text { CONTRACT } \\
\Rightarrow==\approx==== & =======\end{array}$} & $\begin{array}{c}\text { EQUIP. } \\
\text { MENT } \\
=\approx= \pm= \pm==\end{array}$ & $\underset{==\approx \text { B \& I }}{\text { OH\&P }}$ & $\begin{array}{c}\text { TOTAL } \\
\text { DOLLARS } \\
===== \pm=\Rightarrow=\end{array}$ \\
\hline & & & & & & 35,750 & & 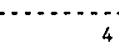 & \\
\hline & & & & & 95 & & 0 & & 42,303 \\
\hline
\end{tabular}


FLUOR DANIEL NORTHWEST, INC COGEMA ENGINEERING CORP

JOB NO. Z466AAA3

FILE NO. 2466AAA3

ACCOUNT

NUMBER

DESCR IPTION

* * IEST - INTERACTIVE ESTIHATING * * TANK REMOVAL

241-AX TANK FARM CLOSURE - PLANNING ESTIMATE PHMCROB - ESTIMATE DETAIL BY WBS $/$ COST CODE
PAGE 12

DATE $05 / 27 / 98 \quad 13: 37: 53$

BY R.OHRT

SUB- EQUIP- OH\&P TOTAL

CODE QUANTITY MANHOURS LABOR USAGE MATERIAL CONTRACT MENT IB I DOLLARS

310200

REMOVE SOIL ABOVE TANKS

310200.01 GENERAL REQUIRHENTS

$310200.0102000 * * * * * * * * * * * * * * * * * * *$

$$
\text { HPT'S }
$$

$460 N$

$1 \mathrm{~L} / \mathrm{S}$

480

22934

0

0

0

22934

2 MEN FOR 6 WEEKS

SUBTOTAL GENERAL REQUIRMENTS

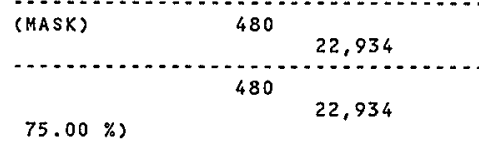

$-$

0

0
0.2.

0

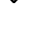

0

-

TOTAL COST CODE 46001

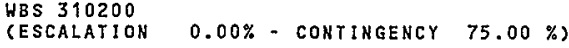
SITEWORK

310200.02

$310200.0201000 * * * * * * * * * * * * * * * * * * * * * * * * * * * *$ EXCAVATE SOIL ABOVE TANKS

ABO*

310200.0201002 REMOVE SOIL FROM AX TANK FARH TO EXPOSE TANK DOMES,

APPROX 20,500 CY OR 27,67

TONS, ASSUME 3 CY BUCKET.

310200.0201003 TRUCKS WITH ROLL -OFF TRAI
ERS CARRYING 20 TON DUMP
CONTAINERS FOR PICK-UP AT

310200.0201003 TRUCKS WITH ROLL-OFF TRAI
ERS CARRYING 20 TON DUMP
CONTAINERS FOR PICK-UP AT

310200.0201003 TRUCKS WITH ROLL -OFF TRAI
ERS CARRYING 20 TON DUMP
CONTAINERS FOR PICK-UP AT
SITE BY OTHERS.

310200.0201004

OPERATOR \& OILER

TEAMSTERS (4 EA) W/20 TON

ROLL-OFF TRAILER.
310200.0201007 ALLOHANCE FOR LINERS, ONE ALLOWANCE FOR LINERS, ONE
FOR EACH 20 TON LOAD Q $\$ 15$ EACH.

310200.0201008 EXCAVATOR FUEL a $16 \mathrm{GAL/HR} \times$ $\$ 1.35 / G A L \times 240 \mathrm{HRS}$.

\section{SUBTOTAL SITEWORK}

CONSUMABLES $\quad 3.20 \%$ GENERAL FOREMAN $7.00 \%$ GENERAL REQUIREMENTS $15.00 \%$ SALES TAK $8.00 \%$

\begin{tabular}{|c|c|c|c|c|c|c|c|c|c|c|c|}
\hline 460 & $M$ & 0 & & 0 & 0 & 0 & 0 & 0 & 0 & 0 & 0 \\
\hline 460 & $M$ & 0 & & 0 & 0 & 0 & 0 & 0 & 0 & 0 & 0 \\
\hline 460 & $M$ & 0 & & 0 & 0 & 0 & 0 & 0 & 0 & 0 & 0 \\
\hline $\begin{array}{l}460 \\
460\end{array}$ & $\begin{array}{l}M \\
M\end{array}$ & $\begin{array}{l}27675 \\
27675\end{array}$ & $\begin{array}{l}\text { TON } \\
\text { TON }\end{array}$ & $\begin{array}{l}493 \\
985\end{array}$ & $\begin{array}{l}16560 \\
33195\end{array}$ & $\begin{array}{l}0 \\
0\end{array}$ & $\begin{array}{l}0 \\
0\end{array}$ & $\begin{array}{l}0 \\
0\end{array}$ & $\begin{array}{l}0 \\
0\end{array}$ & $\begin{array}{l}0 \\
0\end{array}$ & $\begin{array}{l}16560 \\
33195\end{array}$ \\
\hline 460 & $M$ & 1384 & EA & 0 & 0 & 0 & 20760 & 0 & 0 & 1038 & 21798 \\
\hline 460 & $M$ & 1 & $1 / S$ & 0 & 0 & 0 & 5184 & 0 & 0 & 259 & 5443 \\
\hline & $\ddot{G}$ & $(s k)$ & - & 1,478 & $\begin{array}{r}49,755 \\
3482 \\
7985\end{array}$ & 0 & $\begin{array}{r}25,944 \\
1592 \\
2202\end{array}$ & 0 & 0 & 1,297 & $\begin{array}{r}76,996 \\
1592 \\
3482 \\
7985 \\
2202\end{array}$ \\
\hline
\end{tabular}


FLUOR DANIEL NORTHWEST, INC. COGEMA ENGINEERING CORP.

JOB NO. Z466AAA3

FILE NO. 2466AAA3

\section{ACCOUNT \\ NUMBER}

\section{DESCRIPTION}

CODE QUANTITY MANHOURS LABOR USAGE

MATERIAL CONTRACT

PAGE 13

DATE $\quad 05 / 27 / 98 \quad 13: 37: 53$

BY

. OHR

EQUIP -

TOTAL

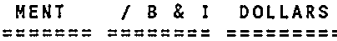

189

TOTAL COST CODE 46002

WBS 310200

SESCALATION

$0.00 \%$ - CONTINGENCY

1,818

1,818

61,223

0

29,739

0

.486

$75.00 \%)$

2,298

84,157

29,739

0

, 486

115,383 
FLUOR DANIEL NORTHWEST, INC. COGEMA ENGINEERING CORP. JOB NO. Z466AAA3

FILE NO, 2466AAA3

\section{ACCOUN T \\ NUMBER}

DESCR IPT ION

PULVERIZE TANK DOMES

310300

$\begin{array}{ll}310300.01 & \text { GENERAL REQUIRMENTS } \\ 310300.0103000 & * * * * * * * * * * * * * * * * * * *\end{array}$
** IEST - INTERACTIVE ESTIMATING **

241-AX TANK FARM CLOSURE - PLANNING ESTIMATE PHMCROB - ESTIMATE DETAIL BY WBS/ COST CODE TANK REMOVAL

\section{HNF-3378-Rev. 0}

PAGE 14

BY R.OHRT
DATE $05 / 27 / 98 \quad 13: 37: 53$

\begin{abstract}
HPT'S
****************************
\end{abstract}

2 MEN FOR 12 DAYS

\section{$\cos T$}

CODE QUANTITY MANHOURS EQUIP
SUB -

ONTRACT

EQUIP MENT

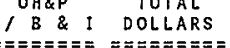

OH\&P, TOTAL

2 MEN FOR 12 DAYS

SUBTOTAL GENERAL REQUIRMENTS

TOTAL COST CODE 46001

WBS 310300

(ESCALATION $0.00 \%$ - CONTINGENCY $75.00 \%$ )

(MASK)

19

19299174

0

o

0

0

9174

(
310300.02

310300.0204000

SITEHORK

CREATE STARTER HOLE IN TANK DOME

$* * * * * * * * * * * * * * * * * * * * * * * * * * * *$

310300.0204002 UTILIZING CATERPILLAR 375

EXCAVATOR W/HYDRAULIC BREAK-

ER ATTACHMENT, BREAK HOLE

THRU TOP CENTER OF DOMES,

390300.0204003 AFTER HOLE IS LARGE ENOUGH

TO PERMIT USAGE OF PULVERIZ-

ER, DECON AND REPLACE BREAK ER: ALLOW ONE DAY.

310300.0204006

310300.0204008

LABORERS, 2 MEN - 1 DAY

MILLWRIGHT - 1 DAY

ALLOWANCE FOR REMAINING 3 TANKS.

OPERATORS

OILERS

LABORERS

MILLWRIGH

PULVERIZE REMAINDER OF TANK

310300.0204018 390300.0204019

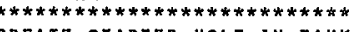

$* * * * * * * * * * * * * * * * * * *$
$460 \mathrm{M} \quad 0$

$460 \mathrm{M} \quad 0$

$460 M$

$460 \mathrm{H}$

$460 \mathrm{~N}$

$460 \mathrm{M}$

$460 \mathrm{M}$

460

$460 \mathrm{M}$

$460 M$

$460 \mathrm{M}$

$460 \mathrm{M}$

460 H

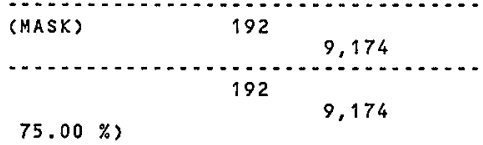

0
0
0

\begin{tabular}{|c|c|}
\hline \multicolumn{2}{|c|}{0} \\
\hline . & \begin{tabular}{l}
9 \\
\hdashline$: 184$
\end{tabular} \\
\hline 0 & 9,174 \\
\hline
\end{tabular}

0

(1)

0

\begin{tabular}{|c|c|c|c|c|c|c|}
\hline 0 & 0 & 0 & 0 & 0 & 0 & 0 \\
\hline 0 & 0 & 0 & 0 & 0 & 0 & 0 \\
\hline 0 & 0 & 0 & 0 & 0 & 0 & 0 \\
\hline $\begin{array}{r}269 \\
269 \\
460 \\
270 \\
0\end{array}$ & $\begin{array}{l}0 \\
0 \\
0 \\
0 \\
0\end{array}$ & $\begin{array}{l}0 \\
0 \\
0 \\
0 \\
0\end{array}$ & $\begin{array}{l}0 \\
0 \\
0 \\
0 \\
0\end{array}$ & $\begin{array}{l}0 \\
0 \\
0 \\
0 \\
0\end{array}$ & $\begin{array}{l}0 \\
0 \\
0 \\
0 \\
0\end{array}$ & $\begin{array}{r}269 \\
269 \\
460 \\
270 \\
0\end{array}$ \\
\hline $\begin{array}{r}806 \\
806 \\
1612 \\
811 \\
0\end{array}$ & $\begin{array}{l}0 \\
0 \\
0 \\
0 \\
0\end{array}$ & $\begin{array}{l}0 \\
0 \\
0 \\
0 \\
0\end{array}$ & $\begin{array}{l}0 \\
0 \\
0 \\
0 \\
0\end{array}$ & $\begin{array}{l}0 \\
0 \\
0 \\
0 \\
0\end{array}$ & $\begin{array}{l}0 \\
0 \\
0 \\
0 \\
0\end{array}$ & $\begin{array}{r}806 \\
806 \\
1612 \\
811 \\
0\end{array}$ \\
\hline
\end{tabular}




\section{HNF-3378-Rev. 0}

FLUOR DAN!EL NORTHHEST, INC.

COGEMA ENGINEERING CORP.

JOB NO. Z466AAA3

FJLE NO. Z466AAA3

ACCOUNT

NUMBER

DESCRIPTION

* IEST - INTERACTIVE ESTIMATING * TANK REHOVAL.

241-AX TANK FARM CLOSURE - PLANNING ESTIMATE PHMCROS - ESTIMATE DETAIL BY HBS / COST CODE

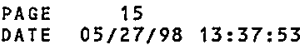

BY R.OHRT

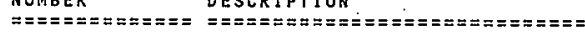

310300.0204120 UTILIZING (2) CATERPILLAR 375 EXCAVATORS W/PULVERIZER, SHEAR AND GRAPPLE, REMOVE

DOME. ALLOW 2 DAYS PER TANK. DOME. ALLOW 2 DAYS
OPERATORS (2)

OPERATORS (
OILERS (2)

LABORERS (4)

MILLWRIGHTS (2)

ALLOWANCE FOR REMAINING

3 TANKS AT 2 DAYS PER TANK.

OPERATORS

OILERS

LABORERS

HILLHRIGHTS

LABORERS TO BE ON HAND FOR

DECONTAMINATION OF ATTACH-

MENTS BEFORE CHANGEOUTS

MILLWRIGHT IS FOR REPAIR AND

310300.0204201 MAINTENANCE OF ATTACHMENTS. ALLOW TWO LABORERS AND ONE

MILLWRIGHT PER OPERATING

EXCAVATOR FOR JOB DURATION.

SUBTOTAL SITEHORK

CONSUMABLES $3.20 \%$ GENERAL FOREMAN $7.00 \%$ GENERAL REQUIREMENTS $15.00 \%$ SALES TAX $8.00 \%$ OH\&P (ON MARKUPS ONLY)

TOTAL

COST CODE 46002

WBS 310300

CESCALATION

$0.00 \%$ - CONTINGENCY $75.00 \%$

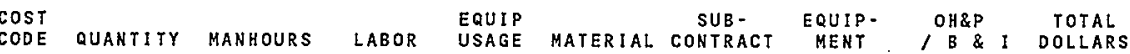

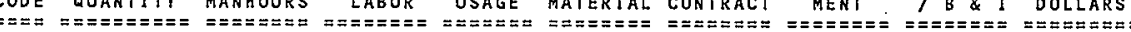

$\begin{array}{llllllllll}460 \mathrm{M} & 0 & 0 & 0 & 0 & 0 & 0 & 0 & 0\end{array}$

\begin{tabular}{|c|c|c|c|c|c|c|c|c|c|c|}
\hline $\begin{array}{l}460 \\
460 \\
460 \\
460 \\
460\end{array}$ & $\begin{array}{l}1 \\
1 \\
1 \\
1 \\
0\end{array}$ & $\begin{array}{l}\text { TK } \\
T K \\
T K \\
T K\end{array}$ & $\begin{array}{r}32 \\
32 \\
64 \\
32 \\
0\end{array}$ & $\begin{array}{r}1075 \\
1075 \\
1839 \\
1081 \\
0\end{array}$ & $\begin{array}{l}0 \\
0 \\
0 \\
0 \\
0\end{array}$ & $\begin{array}{l}0 \\
0 \\
0 \\
0 \\
0\end{array}$ & $\begin{array}{l}0 \\
0 \\
0 \\
0 \\
0\end{array}$ & $\begin{array}{l}0 \\
0 \\
0 \\
0 \\
0\end{array}$ & $\begin{array}{l}0 \\
0 \\
0 \\
0 \\
0\end{array}$ & $\begin{array}{r}1075 \\
1075 \\
1839 \\
1081 \\
0\end{array}$ \\
\hline $\begin{array}{l}460 \\
460 \\
460 \\
460 \\
460\end{array}$ & $\begin{array}{l}3 \\
3 \\
3 \\
3 \\
0\end{array}$ & $\begin{array}{l}\text { TKS } \\
\text { TKS } \\
\text { TKS } \\
\text { TKS }\end{array}$ & $\begin{array}{r}96 \\
96 \\
192 \\
96 \\
0\end{array}$ & $\begin{array}{r}3225 \\
3225 \\
5518 \\
3243 \\
0\end{array}$ & $\begin{array}{l}0 \\
0 \\
0 \\
0 \\
0\end{array}$ & $\begin{array}{l}0 \\
0 \\
0 \\
0 \\
0\end{array}$ & $\begin{array}{l}0 \\
0 \\
0 \\
0 \\
0\end{array}$ & $\begin{array}{l}0 \\
0 \\
0 \\
0 \\
0\end{array}$ & $\begin{array}{l}0 \\
0 \\
0 \\
0 \\
0\end{array}$ & $\begin{array}{r}3225 \\
3225 \\
5518 \\
3243 \\
0\end{array}$ \\
\hline
\end{tabular}

$\begin{array}{rlllllllll}460 \mathrm{M} & 0 & 0 & 0 & 0 & 0 & 0 & 0 & 0 & 0\end{array}$

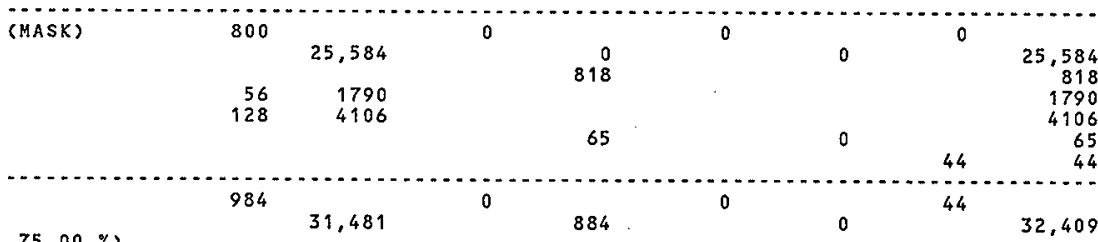

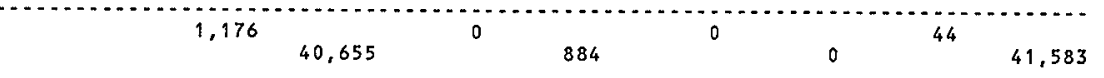


IR DAHIEL NORTHWEST, INC.

AMA ENGINEERING CORP.

NO. 2466AAA3

NO. 2466AAA3
* * iEst - INTERACTIVE ESTIMATING * * TANK REMOVAL

241-AX TANK FARM CLOSURE - PLANNING ESTIMATE PHMCRO8 - ESTIMATE DETAIL BY WBS / COST CODE
PAGE 16

DATE $\quad 05 / 27 / 98 \quad 13: 37: 54$

BY R.OHRT

\begin{tabular}{|c|c|c|c|c|c|c|c|c|c|c|}
\hline $\begin{array}{l}\text { UNT } \\
\text { 医 } R \\
=========\Rightarrow\end{array}$ & 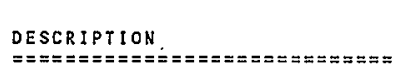 & $\begin{array}{l}\operatorname{COST} \\
\operatorname{CODE} \\
====\end{array}$ & $\begin{aligned} & \text { QUANTI I Y } \\
&======= \pm=\end{aligned}$ & $\begin{array}{l}\text { MANHOURS } \\
=\approx \approx=\approx \equiv=\equiv\end{array}$ & $\begin{aligned} & \operatorname{LABOR} \\
& \Rightarrow=\approx \approx=\approx \approx=\end{aligned}$ & $\begin{array}{l}\text { EQUIP } \\
\text { USAGE } \\
== \pm=\approx \approx=\end{array}$ & $\begin{array}{l}\text { MATER \AL } \\
==\equiv=\approx==\equiv\end{array}$ & $\begin{array}{l}\text { SUB- } \\
\text { CONTRACT } \\
=======\end{array}$ & $\begin{array}{c}\text { EQUIP- } \\
\text { MENT } \\
===\approx==\approx=\end{array}$ & 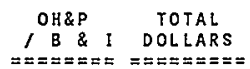 \\
\hline
\end{tabular}

$\infty 0$

00.01 GENERAL REQUIRMENTS

GENERAL REQUIRMENTS HPT IS

1 L/S $3467 \quad 165653$

0

0

0

0

0

165653

2 MEN FOR 44 WEEKS

SUBTOTAL GENERAL REQUIRHENTS

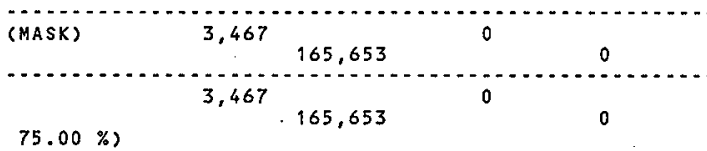

$-$

$+$

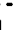

COST CODE 46001
WBS 310400

(ESCALATION $0.00 \%$ - CONTINGENCY $75.00 \%$ )

S!TEWORK

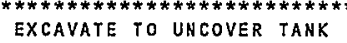
SIDES

$* * * * * * * * * * * * * * * * * * * * * * * * * * * *$

0.0

$460 \mathrm{~W}$

0

0

0

$460 \mathrm{~W} \quad 0$

$\begin{aligned} & 00.0203001 \text { REMOVE SOIL DOWN TO BASE OF } \\ & \text { TANKS UTILIZING EXCAVATOR } \\ & \text { WITH } 3 \text { CY BUCKET, APPROX. } \\ & \text { T44,300 CY OR 194,800 TONS. } \\ & 0.0203002 \text { TRUCKS WITH ROLL-OFF TRAIL. }\end{aligned}$

$\begin{aligned} & 00.0203001 \text { REMOVE SOIL DOWN TO BASE OF } \\ & \text { TANKS UTILIZING EXCAVATOR } \\ & \text { WITH } 3 \text { CY BUCKET, APPROX. } \\ & \text { T44,300 CY OR 194,800 TONS. } \\ & 0.0203002 \text { TRUCKS WITH ROLL-OFF TRAIL. }\end{aligned}$

$\begin{aligned} & 00.0203001 \text { REMOVE SOIL DOWN TO BASE OF } \\ & \text { TANKS UTILIZING EXCAVATOR } \\ & \text { WITH } 3 \text { CY BUCKET, APPROX. } \\ & \text { T44,300 CY OR 194,800 TONS. } \\ & 0.0203002 \text { TRUCKS WITH ROLL-OFF TRAIL. }\end{aligned}$ ERS CARRYING 20 TON DUMP CONTAINERS FOR PICK UP AT SITE BY OTHERS.

$460 \mathrm{~W} \quad 0$

0

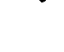

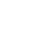

46

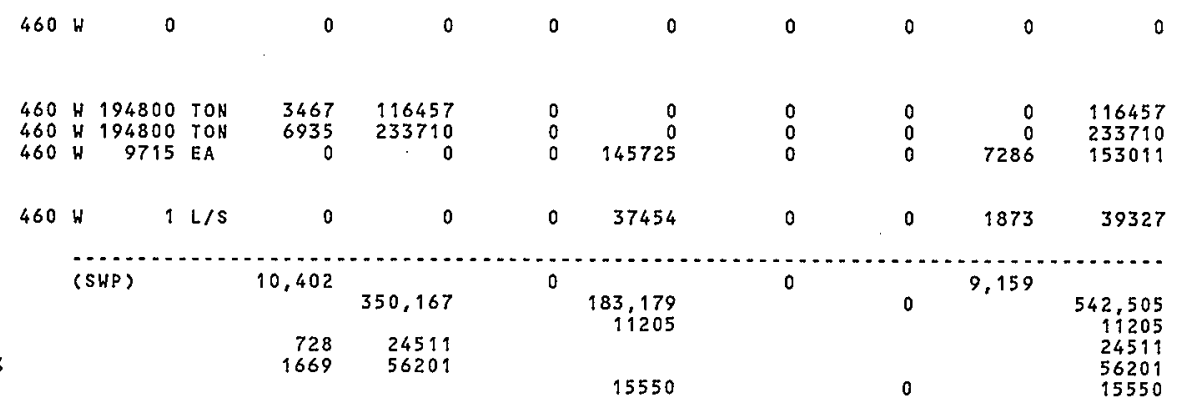

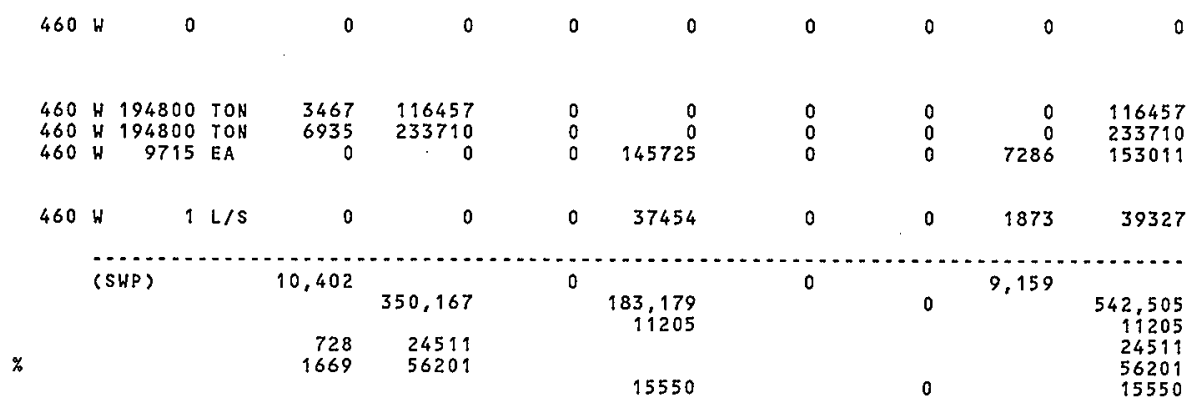
TEAMSTERS ( 4 EA)
7 ALLOHANCE FOR LINERS, ONE
FOR EACH 20 TON LOAD $\$ 15$ EACH.

0.0203010 EXCAVATOR FUEL a 16 GAL/HR $X \$ 1.35 / \mathrm{GAL} X 1734$ HRS.

\section{SUBTOTAL SITEWORK}

CONSUMABLES ' $3.20 \%$

GENERAL FOREMAN $7.00 \%$

GENERAL REQUIREMENTS $15.00 \%$

SALES TAX $8.00 \%$ 
FLUOR DANIEL. NORTHWEST, INC. COGEMA ENGINEERING CORP.

JOB NO. 2466AAA3

EILE NO. Z466AAA3

\section{ACCOUNT} NUMBER DESCRIPTION
* IEST - INTERACTIVE ESTIMATING * * TANK REMOVAL

241-AX TANK FARM CLOSURE - PLANNING ESTIMATE PHMCRO 8 - ESTIMATE DETAIL BY WBS / COST CODE
PAGE 17

DATE $05 / 27 / 98 \quad 13: 37: 54$

BY R.OHRT
EQUIP SUB - EQUIP- OH\&P TOTAL

COOE QUANTITY MANHOURS LABOR USAGE MATERIAL CONTRACT MENT IB \& I DOLLARS

OH\&P (ON MARKUPS ONLY)

TOTAL

COST CODE 46002

WBS 390400

(ESCALATION

$0.00 \%$ - CONTINGENCY $75.00 \%$

12,799

430,880

0

209,935

1337

1337

$10 .+$.

10,496

o

0

651,312

TOTAL WBS 310400 REMOVE SOIL AT TANK SIDES

16,266

596,533

0

209.935

0

10,496

816,965 
HNF-3378-Rev, 0

FLUOR DANIEL NORTHWEST, INC. COGEMA ENGINEERING CORP.

JOB NO. Z466AAA3

FILE NO. Z466AAA3

\section{ACCOUNT \\ NUMBER}

DESCR I PT ION

* * IEST - INTERACTIVE ESTIMATING * * TANK REMOVAL

241-AX TANK FARM CLOSURE - PLANNING ESTIHATE PHMCRO 8 - ESTIMATE DETAIL BY WBS / COST CODE

COST EQUIP

CODE QUANTITY MANHOURS LABOR USAGE \begin{tabular}{lll} 
PAGE & \multicolumn{1}{c}{18} \\
DATE & $05 / 27 / 98$ & $13: 37: 54$ \\
BY & R.OHRT
\end{tabular}
310500

310500.01

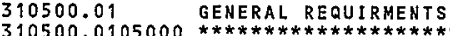

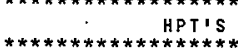

SUB -

EQUIP -

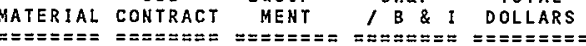

OH\&P

B \& TOTAL

1 L/S $\quad 480 \quad 22934$

0

0

0

22934

2 MEN FOR 6 WEEKS

SUBTOTAL GENERAL REQUIRMENTS

310500.02

310500.0205002 UTILIZING (2) CATERPILLAR

310500.0205003

310500.0205006 ALLOWANCE FOR ONE TANK. 310500.0205008

310500

310500.0205016

310500.0205018

310500.0205020 ALLOHANCE FOR 3 RENAINING

310500.0205

310500.0205026

310500.0205030

310500.0205032

310500.0205040 LABORERS TO BE ON HAND FOR

480
(MASK)
$75.00 \%)$

COST CODE 46001

WBS 310500

(ESCALATION $0.00 \%$ - CONTINGEHCY $75.00 \%$ )

\section{SITEWORK}

REMOVAL OF TANK WALLS

***************************** 375 EXCAVATORS WITH PULVERIZER AND SHEAR, REMOVE WALLS

AND LINER. RUBBLE TO BE

LOADED INTO 20 TON ROLL-OFF CONTAINERS FOR ERDF WITHA CATERPILLAR 988 FRONT-END LOADER. OPERATOR (3) 1 TANE OI LERS (3) 1.5 WEEKS TEAHSTERS ( 2 ) 1.5 WEEKS LABORERS ( 6 ) 1.5 WEEKS MILLURIGHTS (2) 1.5 WEEKS

TANKS.

OPERATORS (3) 4.5 WEEKS

OILERS (3) 4.5 WEEKS

TEAMSTERS $(2) 4.5$ WEEKS

LABORERS (6) 4.5 WEEKS

MILLWRIGHTS ( 2 ) 4.5 HEEKS

$460 \mathrm{M} \quad 0$

$460 M \quad 0$

0

0

0

0
0

0

0
6046
6046
4044
2132
4054
0
8139
8139
2092
1039
2161
0

0
0

0
0
0 $\ldots$

\begin{tabular}{|c|c|c|}
\hline \multirow[t]{2}{*}{0} & \multicolumn{2}{|c|}{0} \\
\hline & 0 & 22,934 \\
\hline 0 & & \\
\hline & 0 & 22,934 \\
\hline
\end{tabular}

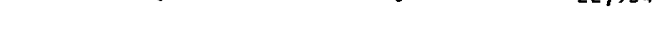

\begin{abstract}
DECNTAMTNATION OF ATTACH
\end{abstract}

$\begin{array}{rrr}0 & & \\ & & \\ & & \\ 0 & & \\ 1 & T K & 180 \\ 1 & T K & 180 \\ 1 & T K & 120 \\ 1 & T K & 360 \\ 1 & T K & 120 \\ 0 & & 0 \\ 3 & T K S & 540 \\ 3 & \text { TKS } & 540 \\ 3 & T K S & 360 \\ 3 & \text { TKS } & 1080 \\ 3 & T K S & 360 \\ 0 & & 0 \\ & & \end{array}$


HNF-3378-Rev. 0

FLUOR DANIEL NORTHWEST, INC. COGEMA ENGINEERING CORP

JOB NO. 2466AAA3

FILE NO. 2466AAA3

\section{ACCOUNT}

NUMBER

NUMBER DESCRIPTION

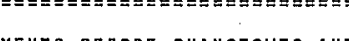

MENTS BEFORE CHANGEOUTS AND

COORD INATING CONTAINER MOVE

$\begin{aligned} & 310500,0205041 \text { MENTS THRU AIRLOCKS. MILL } \\ & \text { WRIGHTSWILL MAINTAIN AND } \\ & \text { REPAIR THE ATTACHMENTS. }\end{aligned}$

310500.0205041 MENTS THRU AIRLOCKS MILL
WRIGHT WILL MAINTAIN AND
REPAIR THE ATTACHMENTS.

$\begin{aligned} & 310500.0205041 \text { MENTS THRU AIRLOCKS. MIL } \\ & \text { WRIGHTS WILL MAINTAIN AN } \\ & \text { REPAIR THE ATTACHMENTS. }\end{aligned}$

ALLOWANCE FOR LINERS, ONE
FOR EACH 20 TON LOAD a \$15 EACH.

SUBTOTAL

\section{SITEWORK}

CONSUMABLES $3.20 \%$

GENERAL FOREMAN $7.00 \%$

GENERAL REQUIREMENIS $15.00 \%$

GENERAL REQUIREMENTS
SALES TAX $8.00 \%$

OH\&P (ON MARKUPS ONLY)

HBS 310500

(ESCALATION

$0.00 \%$ - CONTINGENCY
TOTAL COST CODE 46002

* * IEST - INTERACTIVE Estimatthg * *

TANK REMOVAL

241-AX TANK FARM CLOSURE - PLANNING ESTIMATE PHHCRO8 - ESTIMATE DETAIL BY WBS/ COST CODE

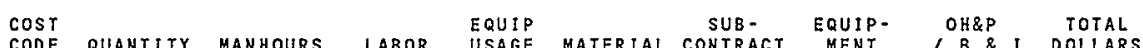

CODE QUANTITY MANHOURS LABOR USAGE MATERIAL CONTRACT MENT I B \& DOLLARS

$\begin{array}{llllllllll}460 \mathrm{M} & 0 & 0 & 0 & 0 & 0 & 0 & 0 & 0 & 0\end{array}$

460

213

0

0

0

3195

0

0

160

3355

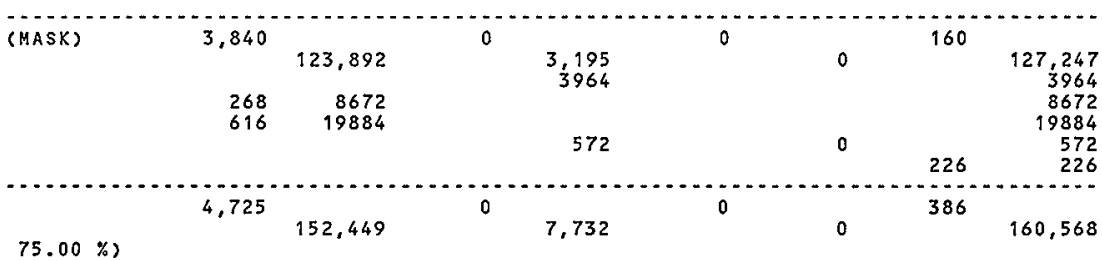

TOTAL HBS 310500 REMOVE TANK WALLS
386
0

175,383
7,732

0

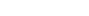


FLUOR DANIEL NORTHWEST, INC. COGEMA ENGINEERING CORP.

JOB HO. Z466AAA3

FILE NO. Z466AAA3

\section{ACCOUNT}

NUMBER

DUMBER
DESCRIPTION

REMOVE TANK BOTTOMS

310600

$\begin{array}{ll}310600.01 & \text { GENERAL REQUIRHENTS } \\ 310600.0106000 & * * * * * * * * * * * * * * * * * * *\end{array}$

HPT'S

*******************1

2 MEN FOR 32 DAYS

SUBTOTAL

GENERAL REQUIRHENTS

TOTAL

COST CODE 46001

WBS 310600

(ESCALATION

$0.00 \%$ - CONTINGENCY

S I TEWORK

310600.02

310600.0206000

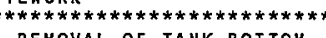

REMOVAL OF TAKK BOTTOM

$* * * * * * * * * * * * * * * * * * * * * * * * * * * *$

310600.0206002 UTILIZING CATERPILLAR 375

EXCAVATORS W/ PICK HAMMER,

PULVERIZER \& SHEAR AND CAT-

ERPILLAR 988 LOADER, REMOVE

310600.0206003 BASE OF TANK, LINER, CDF

FILL, 360 CF OF SOLIDIFIED

SLUDGE, PLUS 3" OF UNDERLY -

ING SOIL. DUE TO THE HIGH

310600.0206004 RAOIATION, SPECIAL CONTAIN-

ERS HILL BE REQUIRED, THESE

WILL HOLD APPROX. 3.5 CY,

365 DF THESE CONTAINERS WILL

BE REQUIRED FOR EACH TANK

1460 TOTAL: ASSUME THAT 4

TRUCKS \& TRAILERS CAN OPER-

ATE WITHIN THE PIT AREA AND

310600.020600

$\begin{aligned} 310600.0206006 & \text { ATE WITHIN THE PIT AREA AND } \\ & \text { EACH TRUCK IS ABLE TO COMPL } \\ & \text { ESTIMATED THAT EACH TANK } \\ & \text { WILL TAKE 8 DAYS. } \\ 310600.0206036 & \text { ALLOWANCE FOR ONE TANK: } \\ 310600.0206038 & \text { OPERATORS (3) } 8 \text { DAYS } \\ 310600.0206040 & \text { OILERS (3) } 8 \text { DAYS }\end{aligned}$

$\begin{aligned} 310600.0206006 & \text { ATE WITHIN THE PIT AREA AN } \\ & \text { ETE TR T LOADS PER HOUR. IT I } \\ & \text { ESTIMATED THAT EACH TANK } \\ & \text { WILL TAKE 8 OAYS. } \\ 310600.0206036 & \text { ALLOWANCE FOR ONE TANK: } \\ 310600.0206038 & \text { OPERATORS (3) 8 DAYS } \\ 310600.0206040 & \text { OILERS (3) } 8 \text { DAYS }\end{aligned}$

$\begin{aligned} & 310600.0206006 \text { ATE HITHIN THE PIT AREA } \\ & \text { EACH TRUCK IS ABLE TO CO } \\ & \text { ETE 2 LOADS PER HOUR. IT } \\ & \text { ESTIMATED THAT EACH TANK } \\ & \text { WILL TAKE 8 DAYS. } \\ & 310600.0206036 \text { ALLOWANCE FOR ONE TANK: } \\ & 310600.0206038 \text { OPERATORS (3) } 8 \text { DAYS } \\ & 310600.0206040 \text { OILERS (3) } 8 \text { DAYS }\end{aligned}$

$\begin{aligned} 310600.0206006 & \text { ATE HITHIN THE PIT AREA } \\ & \text { ETE TRUCK IS ABLE TO C } \\ & \text { ESTIMATED THAT EACH TAN } \\ & \text { WILL TAKE 8 DAYS. } \\ 310600.0206036 & \text { ALLOWANCE FOR ONE TANK: } \\ 310600.0206038 & \text { OPERATORS (3) } 8 \text { DAYS } \\ 310600.0206040 & \text { OILERS (3) } 8 \text { DAYS }\end{aligned}$

$\begin{aligned} 310600.0206006 & \text { ATE HITHIN THE PIT AREA } \\ & \text { ETE TRUCK IS ABLE TO C } \\ & \text { ESTIMATED THAT EACH TAN } \\ & \text { WILL TAKE 8 DAYS. } \\ 310600.0206036 & \text { ALLOWANCE FOR ONE TANK: } \\ 310600.0206038 & \text { OPERATORS (3) } 8 \text { DAYS } \\ 310600.0206040 & \text { OILERS (3) } 8 \text { DAYS }\end{aligned}$

$\begin{aligned} 310600.0206006 & \text { ATE HITHIN THE PIT AREA } \\ & \text { ETE TRUCK IS ABLE TO C } \\ & \text { ESTIMATED THAT EACH TAN } \\ & \text { WILL TAKE 8 DAYS. } \\ 310600.0206036 & \text { ALLOWANCE FOR ONE TANK: } \\ 310600.0206038 & \text { OPERATORS (3) } 8 \text { DAYS } \\ 310600.0206040 & \text { OILERS (3) } 8 \text { DAYS }\end{aligned}$

$\begin{aligned} 310600.0206006 & \text { ATE HITHIN THE PIT AREA } \\ & \text { ETE TRUCK IS ABLE TO C } \\ & \text { ESTIMATED THAT EACH TAN } \\ & \text { WILL TAKE 8 DAYS. } \\ 310600.0206036 & \text { ALLOWANCE FOR ONE TANK: } \\ 310600.0206038 & \text { OPERATORS (3) } 8 \text { DAYS } \\ 310600.0206040 & \text { OILERS (3) } 8 \text { DAYS }\end{aligned}$

$\begin{aligned} 310600.0206006 & \text { ATE HITHIN THE PIT AREA } \\ & \text { ETE TRUCK IS ABLE TO C } \\ & \text { ESTIMATED THAT EACH TAN } \\ & \text { WILL TAKE 8 DAYS. } \\ 310600.0206036 & \text { ALLOWANCE FOR ONE TANK: } \\ 310600.0206038 & \text { OPERATORS (3) } 8 \text { DAYS } \\ 310600.0206040 & \text { OILERS (3) } 8 \text { DAYS }\end{aligned}$

$\begin{aligned} 310600.0206006 & \text { ATE HITHIN THE PIT AREA } \\ & \text { ETE TRUCK IS ABLE TO C } \\ & \text { ESTIMATED THAT EACH TAN } \\ & \text { WILL TAKE 8 DAYS. } \\ 310600.0206036 & \text { ALLOWANCE FOR ONE TANK: } \\ 310600.0206038 & \text { OPERATORS (3) } 8 \text { DAYS } \\ 310600.0206040 & \text { OILERS (3) } 8 \text { DAYS }\end{aligned}$

$460 M$

$460 \mathrm{M}$

$460 \mathrm{H}$

$460 \mathrm{M}$

$460 \mathrm{M}$

$460 \mathrm{M}$
** IEST - INTERACTIVE ESTIMATING ** TANK REMOVAL

241-AX TANK FARM CLOSURE - PLANNING ESTIMATE PHMCRO8 - ESTIMATE DETAIL BY WBS / COST CODE

\section{PAGE 20 \\ DATE $05 / 27 / 98 \quad 13: 37: 54$ \\ BY R.OHRT}

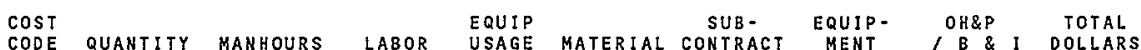

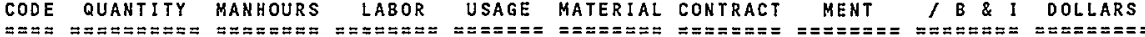

0

0

0

0

24463

\begin{tabular}{|c|c|}
\hline (MASK) & $512 \quad 24,463$ \\
\hline & 24,463 \\
\hline
\end{tabular}

$460 M$

0

0

0

0

0

0

24,463

24,463

0

0

0

0

\section{0}

0

0

0

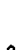

0

0

0

0

$\stackrel{0}{1}$ TK

0
192
192

1 TK

0

(1)

0

0

. 
HNE-3378-Rev. 0

FLUOR DANIEL NORTHWEST, INC. COGEMA ENGINEERING CORP.

JOB NO. Z466AAA3

FILE NO. Z466AAA3

\section{ACCOUNT \\ NUMBER}

DESCR I PIION

* IEST - INTERACTIVE ESTIMATING * TANK REMOVAL

241-AX TANK FARM CLOSURE - PLANNING ESTIMATE PHMCROB - ESTIMATE DETAIL BY WBS / COST CODE

\section{$\begin{array}{lcl}\text { PAGE } & 21 \\ \text { DATE } & 05 / 27 / 98 & 13: 37: 54\end{array}$ \\ BY R.OHRT}

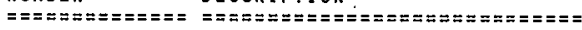

COST EQUIP SUB- EQUIP- OH\&P TOTAL.

CODE QUANTITY MANHOURS LABOR USAGE MATERIAL CONTRACT MENT $/ B \& 1$ DOLLARS

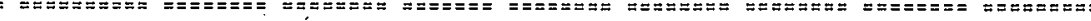

310600.0206042

310600.0206048

TEAMSTERS (4) 8 DAYS

LABORERS (6) 8 DAYS

MILLLRIGHTS (2) 8 DAYS

310600.0206100 ALLOHANCE FOR THREE REMAIN-

310600.0206100 ALLOHANCE FOR THREE REMAIN-

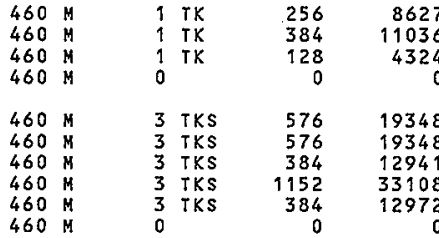

OILERS (3) 24 DAYS

TEAHSTERS (2) 24 DAYS

LABORERS (6) 24 DAYS

MILLWRIGHTS (2) 24 DAYS

$\angle A B O R E R S$ TO BE ON HAND FOR

DECONTAMINATION OF ATTACH -

0 TKS

0

12972
0

0

0

0

0

0

8627

11036

4324

COOROINATING CONTAINER MOV WRIGHTS MAINTAIN AND REPAIR THE ATTACHMENTS.

SUBTOTAL

\section{SITEWORK}

CONSUMABLES $\quad 3.20 \%$

GENERAL FOREHAN $7.00 \%$

GENERAL REQUIRENENTS $15.00 \%$

SALES TAX $\cdot 8.00 \%$

OH\&P (ON HARKUPS ONLY)

$\begin{array}{lrr}\text { (MASK) } & 4,224 & 134,602 \\ & & \\ & 295 & 9422 \\ & 677 & 21603 \\ & & \\ & 5,197 & \\ 75.00 \%) & & 165,627\end{array}$

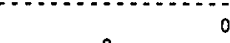

4307

4307

(1)

0

0 34,602 4307 942.

21603 344

TOTAL COST CODE 46002

WBS 310600

$0.00 \%$ - CONTINGENCY

$75.00 \%$
5,709

190,090

0

4,651

0

(

232

194,975 
FLUOR DANIEL NORTHWEST, INC. COGEMA ENGINEERING CORP. JOB NO. Z466AAA3

FILE NO. Z466AAA3

\section{ACCOUNT \\ NUMBER}

DESCRIPTION

MAIN BUILDING

320700

320700.13

320700.1307000

320700.1307002 320700.1307004

320700.1307006

320700.1307008 320700.1307020 320700.1307030 320700.1307040 320700.1307042 320700.1307050 320700.1307050
320700.1307052 320700.1307052 320700.1307060 320700.1307064

SPECIAL CONSTRUCTION
$* * * * * * * * * * * * * * * * * * * * * * * * * *$
501 MAIN BUILDING

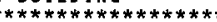

FOUNDATION

SPREAD FOOTINGS, $101 X$

$101 X 21$ THICK.

END WALL FOOTINGS, $6: x$

$6^{t} \times 18^{t 1}$ THICK.

GRADE BEAM, $18^{\mathrm{i}} \mathrm{W} \times 4^{1} \mathrm{H}$

SUPERSTRUCTURE

EXTERIOR CLOSURE DOORS

NTERIOR CLOSURE DOORS

MECHANICAL

FIRE PROTECTION

ELECTRICAL

SERVICE AND DISTRIBUTION

LIGHIING, AT ONE WATT PER

SQUARE FOOT

SUBTOTAL SPECIAL CONSTRUCTION

SALES TAX $8.00 \%$

OH\&P (ON MARKUPS ONLY)

TOTAL COST CODE 50113

WBS 320700

(ESCALATION $0.00 \%$ - CONTINGENCY

MECHANICAL

$\star * * * * * \star * \star * * * * * * * * * * * * * * * * * * * \quad 501$ WASH FACILITY

FACIL*************

$320700 \cdot 15$

ALLOWANCE BASED ON SIMILAR

REQUIREMENT FOR W259. PRICE

INCLUDES POHER, PIPING,

TANKS, CONPRESSOR, BUILDING,

320700.1507004 FREEZE PROTECTION, HEPA
FILTRATION, TRANSFER PUMPS,
* * IEST - INTERACTIVE ESTIMATING * * TANK REMOVAL

241-AX TANK FARM CLOSURE - PLANNING ESTIMATE PHMCRO 8 - ESTIMATE DETAIL BY HBS / COST CODE
PAGE 22

DATE $05 / 27 / 98 \quad 13: 37: 54$

BY R.OHRT

COST QUANTITY MANHOURS SUUIP SUB EQUIP- OH\&P

CODE QUANTITY MANHOURS LABOR USAGE MATERIAL CONTRACT MENT / B \& I DOLLARS

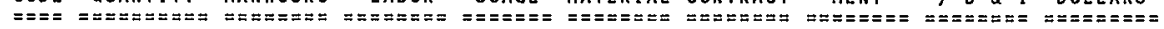

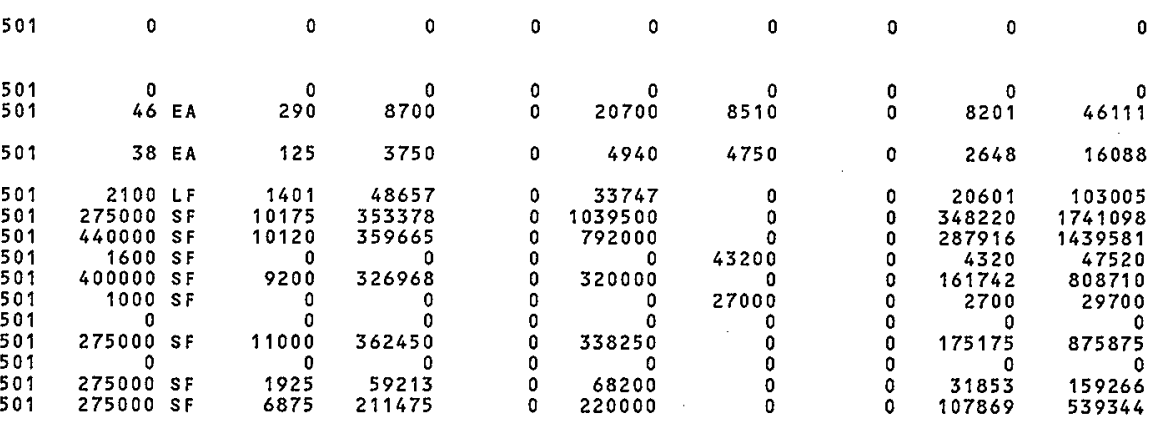

51,111 $1,734,256$

0

837,337

83,460

51.111

$1,734,256$

0

$20.00 \%)$

\section{0}

$1 \mathrm{~L} / \mathrm{S}$

882

0

0

0

0

0

501
0

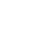

0

0

0

o

0

0

$0 \quad 0 \quad 0$


FLUOR DANIEL NORTHHEST, INC. COGEMA ENGINEERING CORP.

JOB NO. Z466AAA3

FILE NO. Z466AAA3

ACCOUNT

NUMBER

DESCRIPTION

* IEST - INTERACTIVE ESTIMATING ** TANK REMOVAL

241-AX TANK FARM CLOSURE - PLANNING ESTIMATE PHMCROB - ESTIMATE DETAIL BY WBS/ COST CODE

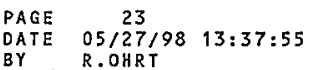

CODE QUANTITY MANHOURS LABOR USAGE MATERIAL CONTRACT MENT IB\& I DOLLARS

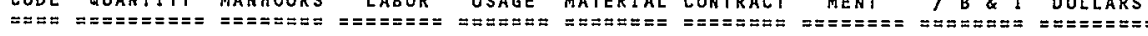

AND INSTRUMENTATION VENTILATION SYSTEM $* * * * * * * * * * * * * * * * * * * * * * * * * * * *$ $320700.1507102 *$ SUPPLY* FAN, 112,500 SCFH, 200 HP 501 EVAPORATIVE COOLER 112,500 SCFM

320700.1507107 PREFILTER

320700.1507109 VALVE/DAMPER, 721" DIA

320700.1507190 DISCHARGE NOZZLES/GRILLS

320700.1507120 DUCT, 16 GA SST, 84" DIA FABR I CATE

320700.1507122 INSTALL

320700.1507124 DUCT, 16 GA SST, 601 DIA FABRICATE

320700.1507126 INSTALL.

320700.1507128 HANGER ALLOWANCE

320700.1507200 *EXHAUST*

320700.1507202 FAN, 122,500 SCFM

320700.1507204 VALVE/DAMPER, 60 tt

320700.1507206 VALVE IDAMPER, 72"

320700.1507208 SUCTION NOZZLES/GRILLS

320700.1507210 DUCT, 16 GA SST, 841

FABRICATE

320700.1507212 INSTAL

320700.1507214 DUCT, 16 GA SST, 60"

FABRICATE

320700.1507216 INSTALL

320700.1507220 HANGER ALLOWANCE

320700.1507300 *STACK*

106" DIAMETER BY 200 FT HIGH

EXCAVATION/BACKFILL FOR

STACK PAD, FAN EQUIPMENT PAD

AND DEAD MAN ANCHORS (ASSUME MACHINE DIG)

320700.1507306 STACX FOUNDATION,

ALLOW FOR $81 \times 201 \times 20$

501

501

501
501

501

501

501
501

501

501
501

501
501

501

50

501

501

501

501

501
501

501

501

501

501

(

1

1 EA

$\begin{array}{rr}0 & 0 \\ 64 & 2275 \\ 160 & 5686\end{array}$

1 EA

1 EA

$2 E A$

$150 \mathrm{LF}$

00

150 LF

200 LF

10
99

284
355

3518

198

7037

$200 \mathrm{LF}$

$1 \mathrm{~L} / \mathrm{S}$

0

1 EA

5 EA

$1 E A$

5 EA

300 LF

$300 \mathrm{LF}$

$650 \mathrm{LF}$

650 LF

$1 L / S$

$1 \mathrm{~L} / \mathrm{S}$

$$
94
$$

3341

$188 \quad 6682$

6682
1937

0
2275

889

213

213
889

7037

14074

14074
10875

21715

3128

6292

501

320700.1507310 ISOKINETIC.STACK SAMPLING

320700.1507310 ISOKINETIC.STACK SAMPLING 320700.1507312 INSTALL AIR MONITOR IN STACK $320700.150732020 \mathrm{FT} \times 3 / 16^{\prime \prime}$ WALL
501 501
501

$\begin{array}{rlrrrr}1 \text { L/S } & 400 & 11200 & 0 & 10667 \\ 1 \text { EA } & 240 & 7382 & 0 & 1000000 \\ 4270 \text { LA } & 24 & 738 & 0 & 11000 \\ 43 & 43 & 1726 & 0 & 12810\end{array}$

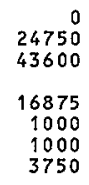$$
0
$$$$
3560
$$$$
0
$$$$
200
$$$$
27750
$$$$
2500
$$$$
700
$$$$
2500
$$$$
7500
$$$$
11570^{\circ}
$$$$
\begin{array}{r}
0 \\
550 \\
0
\end{array}
$$$$
0
$$

0

667

12810

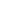

0

0

0

6756

12322

4219

321
339

339
1817

1759

1725

1679
334

334

7506

7506

847
228

228
847

3634

3519

5611

5429

920
0

1573

5467

27334

251846

1259228

$\begin{array}{ll}0 & 2935 \\ 0 & 3634\end{array}$

14673
18170

0 
FLUOR DANIEL NORTHWEST, INC.

COGEMA ENGINEERING CORP.

JOB NO. Z466AAA3

FILE NO. 2466AAA3

\section{ACCOUNT \\ NUNBER}

DESCR IPI ION

* IEST - InTERACTIVE ESTIMATING * TANK REMOVAL

241-AX TANK FARM CLOSURE - PLANNING ESTIMATE PHMCROS - ESTIMATE DETAIL BY WBS / COST CODE
PAGE 24

DATE $05 / 27 / 98 \quad 13: 37: 55$

BY R.OHRT
320700.1507321 WELD STACK SECTIONS AT

$$
10 \text { FT }
$$

320700.150732220 FT X 1/4" WALL

320700.1507323

WELD STACK SECTIONS AT $10 \mathrm{FT}$

320700.150732420 FT X 5/16" WALL

WELD STACK SECTIONS AT $10 \mathrm{FT}$

320700.150732620 FT X 3/81" WALL

320700.1507327 $10 \mathrm{FT}$

320700.150732840 FT X 1/2" WALL

320700.1507329 WELD STACK SECTIONS AT $10 \mathrm{FT}$

$320700.150733040 \mathrm{FT} \times 5 / 811$ HALL

320700.1507331

FT $X$ $5 / 8$ WALL
WELD STACK SECTIONS AT $10 \mathrm{FT}$

320700.150733240 FT X 3/4" WALL 320700.1507333 WELD STACK SECTIONS AT $10 \mathrm{FT}$

320700.1507340 BASE PLATE, $106 "$ DIA $\times 24^{\prime \prime}$ WIDE X 1-3/4"THICK, RING UPPER PLATE, $106 "$ DIA X $20 "$

320700.1507342 UPPER PLATE, 106" DIA X 2
320700.1507344 GIOE GUSETS, $1-3 / 4 "$ THICK, RING
$34 \% \times 11$

320700.1507342 UPPER PLATE, 106" DIA X
320700.1507344 GIDEX $1-3 / 4 "$ THICK, RIN
32 TST, $24 " \times 24 " X 11$ 320700.1507344 GUSSE

320700.1507346 BOLTS AND NUTS

320700.1507348 WELD STACK BASE AND GUSSETS 320700.1507500 HEPA FILTER HOUSING 122,500 SCFM
12 T 320700.1507502 EQUIPMENT SLAB ON GRADE,
ALLOW FOR 12" X 401X 60 ' 320700.1507502 EQUIPMENT SLAB ON GRADE,
ALLOW FOR 12" X 401X 60 ' 320700.1507504 ELECTROST
320700.1507506 PREFILTER

SUBTOTAL MECHANICAL

SALES TAX $8.00 \%$

OH\&P (ON MARKUPS ONLY)

TOTAL COST CODE 50115 WBS 320700
COST
CODE QUANTITY MANHOURS LABOR UQUIP
USAGE MATERIAL CONTRACT MEUIP- OH\&P T I B I DOLLARS

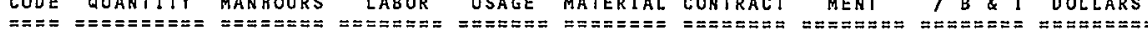

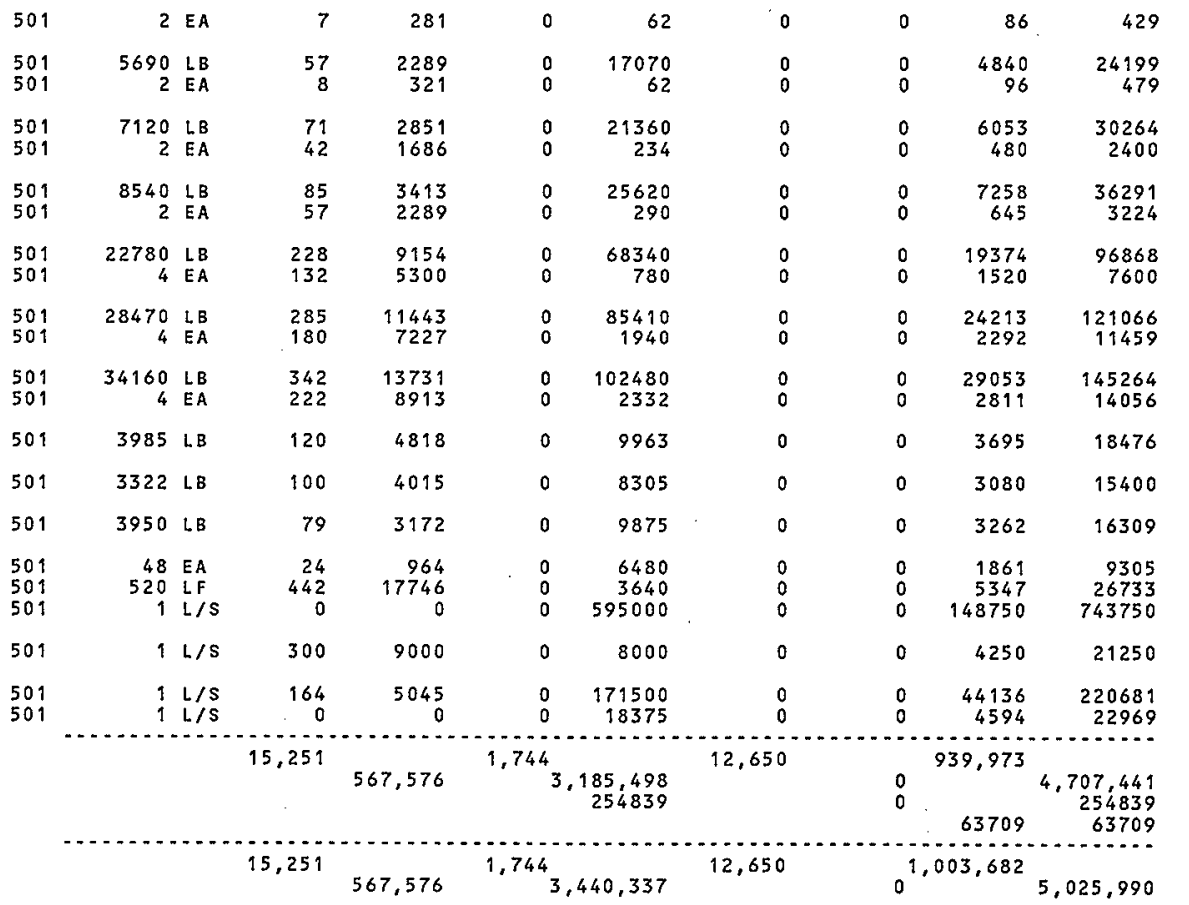


FLUOR DANIEL NORTHWEST, ING.

COGEMA ENGINEERING CORP.

$J O B$ NO. Z466AAA3

FILE NO. Z466AAA3

\section{ACCOUNT}

NUMBER

$\begin{array}{ll}\text { NUMBER } & \text { DESCRIPTION } \\ ===========0=======\end{array}$

(ESCALATION

$0.00 \%$

CONTINGENCY

TOTAL WBS 320700 MAIN BUILDING
* * IEST - INTERACTIVE ESTIMATING **

TANK RENOVAL

241-AX TANK FARM CLOSURE - PLANNING ESTIMATE PHMCR08 - ESTIMATE DETAIL BY WBS/ COST CODE

$\cos Y$

COSY
CODE QUANTITY MANHOURS LABOR USAGE

SUB -

MATERIAL CONTRACT

MENT

PAGE 25

DATE $05 / 27 / 98 \quad 13: 37: 55$

BY

R. OHRT

$0.00 \%$

$20.00 \%$

$66,362,301,832 \quad{ }^{1,744}{ }_{6,504,661}, 36,110 \quad 0.211,674,11,116,022$


FLUOR DANIEL NORTHWEST, INC. COGEMA ENGINEERING CORP

JOB NO. 2466AAA3

FILE NO. 2466AAA3
* * IEST - interactive estimating ** TANK REMOVAL

241-AX TANK FARM CLOSURE - PLANNING ESTIMATE PHMCROS - ESTIMATE DETAIL BY WBS/ COST CODE

\section{$\begin{array}{lcl}\text { PAGE } & 26 \\ \text { DATE } & 05 / 27 / 98 & 13: 37: 55\end{array}$ \\ BY R.OHRT}

\begin{tabular}{|c|c|c|c|c|c|c|c|c|c|c|c|c|}
\hline $\begin{array}{l}\text { ACCOUNT } \\
\text { NUNBER } \\
== \pm========7=\end{array}$ & 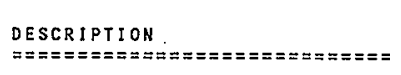 & $\begin{array}{l}\text { COST } \\
\text { CODE } \\
== \pm=\end{array}$ & $\begin{array}{l}\text { QUANTII } \\
=======\end{array}$ & $\begin{array}{l}T Y \\
===\end{array}$ & $\begin{array}{l}\text { MANHOURS } \\
== \pm=\approx= \pm=\end{array}$ & $\begin{array}{c}\text { LABOR } \\
=======\end{array}$ & $\begin{array}{l}\text { EQUIP } \\
\text { USAGE } \\
= \pm=====\end{array}$ & $\begin{array}{l}\text { MATERIAL } \\
======\approx=\end{array}$ & $\begin{array}{c}\text { SUB - } \\
\text { CONTRACI } \\
=======\end{array}$ & $\begin{array}{c}\text { EQUIP - } \\
\text { MENT } \\
=======\end{array}$ & $==\begin{array}{c}\text { OH\&P } \\
B \& \& I\end{array}$ & $\begin{array}{c}\text { TOTAL } \\
\text { DOLLARS } \\
==\mp=\# \#==\end{array}$ \\
\hline 320800 & SUPPORT FACILITY & & & & & & & & & & & \\
\hline $\begin{array}{l}320800.15 \\
320800.1508000\end{array}$ & $\begin{array}{l}\text { MECHAN ICAL } \\
* * * * * * * * * * * * * * * * * * * * * * * * * * *\end{array}$ & & & & & & & & & & & \\
\hline & $\begin{array}{c}\text { SUPPORT FACILITY } \\
* * * * * * * * * * * * * * * * * * * * * * * * * *\end{array}$ & 507 & 0 & & 0 & 0 & 0 & 0 & 0 & 0 & 0 & 0 \\
\hline $\begin{array}{l}320800.1508002 \\
320800.1508004 \\
320800.1508006 \\
320800.1508008\end{array}$ & $\begin{array}{l}\text { 75: } X 75{ }^{\prime} \times 20^{\prime} \text { EAVE HT } \\
\text { FOUNDAION AND DRIVE WAY } \\
\text { FORMS } \\
\text { REBAR } \\
\text { SLAB ON GRADE, INCLUDING } \\
\text { DRIVE HAY }\end{array}$ & $\begin{array}{l}501 \\
501 \\
501 \\
501\end{array}$ & $\begin{array}{r}0 \\
475 \\
12750 \\
9375\end{array}$ & $\begin{array}{l}\text { L.F } \\
\text { L.B } \\
\text { SF }\end{array}$ & $\begin{array}{r}0 \\
38 \\
89 \\
188\end{array}$ & $\begin{array}{r}0 \\
1169 \\
3091 \\
5061\end{array}$ & $\begin{array}{r}0 \\
29 \\
0 \\
1594\end{array}$ & $\begin{array}{r}0 \\
352 \\
3188 \\
12188\end{array}$ & $\begin{array}{l}0 \\
0 \\
0 \\
0\end{array}$ & $\begin{array}{l}0 \\
0 \\
0 \\
0\end{array}$ & $\begin{array}{r}0 \\
388 \\
1570 \\
4711\end{array}$ & $\begin{array}{r}0 \\
1938 \\
7849 \\
23554\end{array}$ \\
\hline $\begin{array}{l}320800.1508020 \\
320800.1508022\end{array}$ & $\begin{array}{l}\text { BUILDING } \\
75, \times 75, \times 20^{\prime} \text { EAVE HT } \\
\text { METAL BLDG, } 26 \text { GA, CLEAR } \\
\text { SPAN. }\end{array}$ & $\begin{array}{l}501 \\
501\end{array}$ & 5625 & $S F$ & $\begin{array}{r}0 \\
338\end{array}$ & $\begin{array}{r}0 \\
11830\end{array}$ & 5625 & 28125 & $\begin{array}{l}0 \\
0\end{array}$ & $\begin{array}{l}\mathbf{0} \\
\mathbf{0}\end{array}$ & 11395 & $\begin{array}{r}0 \\
56975\end{array}$ \\
\hline $\begin{array}{l}320800.1508024 \\
320800.1508026 \\
320800.1508028 \\
320800.1508030 \\
320800.1508040\end{array}$ & $\begin{array}{l}\text { ENTRANCE CANOPY, } 4{ }^{\circ} \times 81 \\
\text { DOORS, } 3670 \\
\text { WINDOWS, } 4030 \\
\text { ROLL-UP DOORS, } 20 \times 24 \\
\text { GUTTER, VALLEY TYPE } \\
\text { BETWEEN BUILDINGS }\end{array}$ & $\begin{array}{l}501 \\
501 \\
501 \\
501 \\
501\end{array}$ & $\begin{array}{r}2 \\
2 \\
6 \\
2 \\
100\end{array}$ & $\begin{array}{l}E A \\
E A \\
E A \\
E A \\
\text { LF }\end{array}$ & $\begin{array}{r}8 \\
8 \\
12 \\
48 \\
14\end{array}$ & $\begin{array}{r}284 \\
246 \\
369 \\
1476 \\
498\end{array}$ & $\begin{array}{r}106 \\
106 \\
36 \\
400 \\
0\end{array}$ & $\begin{array}{r}450 \\
570 \\
1110 \\
26000 \\
320\end{array}$ & $\begin{array}{l}0 \\
0 \\
0 \\
0 \\
0\end{array}$ & $\begin{array}{l}0 \\
0 \\
0 \\
0 \\
0\end{array}$ & $\begin{array}{r}210 \\
231 \\
379 \\
6969 \\
205\end{array}$ & $\begin{array}{r}1050 \\
1153 \\
1894 \\
34845 \\
1023\end{array}$ \\
\hline $\begin{array}{l}320800.1508042 \\
320800.1509000\end{array}$ & $\begin{array}{l}\text { INSULATION, R11 } \\
* * * * * * * * * * * * * * * * * * * * * * * * * * \\
\text { MAINTENANCE FACILITY } \\
* * * * * * * * * * * * * * * * * * * * * * * * * * * *\end{array}$ & $\begin{array}{l}501 \\
501\end{array}$ & $\begin{array}{r}8750 \\
0\end{array}$ & SF & $\begin{array}{r}70 \\
0\end{array}$ & $\begin{array}{r}2476 \\
0\end{array}$ & $\begin{array}{l}0 \\
0\end{array}$ & $\begin{array}{r}3500 \\
0\end{array}$ & $\begin{array}{l}0 \\
0\end{array}$ & $\begin{array}{l}0 \\
0\end{array}$ & $\begin{array}{r}1494 \\
0\end{array}$ & $\begin{array}{r}7470 \\
0\end{array}$ \\
\hline $\begin{array}{l}320800.1509002 \\
320800.1509004 \\
320800.1509006 \\
320800.1509008\end{array}$ & $\begin{array}{l}\text { 30' } X 50^{\prime} X 20^{\prime} \text { EAVE HT } \\
\text { FOUNDATION AND DRIVE WAY } \\
\text { FORMS } \\
\text { REBAR } \\
\text { SLAB ON GRADE, INCLUDING } \\
\text { DRIVE WAYS }\end{array}$ & 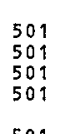 & $\begin{array}{r}30 \\
340 \\
4500 \\
3300\end{array}$ & $\begin{array}{l}\text { LF } \\
\text { LB } \\
\text { SF }\end{array}$ & $\begin{array}{r}0 \\
27 \\
32 \\
66\end{array}$ & $\begin{array}{r}0 \\
831 \\
1111 \\
1777\end{array}$ & $\begin{array}{r}0 \\
20 \\
0 \\
561\end{array}$ & $\begin{array}{r}0 \\
252 \\
1125 \\
4290\end{array}$ & $\begin{array}{l}0 \\
0 \\
0 \\
0\end{array}$ & $\begin{array}{l}0 \\
0 \\
0 \\
0\end{array}$ & $\begin{array}{r}0 \\
276 \\
559 \\
1657\end{array}$ & $\begin{array}{r}0 \\
1379 \\
2795 \\
8285\end{array}$ \\
\hline $\begin{array}{l}320800.1509020 \\
320800.1509022\end{array}$ & $\begin{array}{l}\text { BUILDING } \\
301 X \text { X01 X } 201 \text { EAVE HT } \\
\text { METAL } 8 L D G, 26 \text { GA, CIEAR } \\
\text { SPAN. }\end{array}$ & $\begin{array}{l}501 \\
501\end{array}$ & $1500^{0}$ & SF & $\begin{array}{l}0 \\
0\end{array}$ & $\begin{array}{l}0 \\
0\end{array}$ & $\begin{array}{r}0 \\
1500\end{array}$ & $\begin{array}{l}0 \\
0\end{array}$ & $\begin{array}{l}0 \\
0\end{array}$ & $\begin{array}{l}0 \\
0\end{array}$ & $\begin{array}{r}0 \\
375\end{array}$ & $\begin{array}{r}0 \\
1875\end{array}$ \\
\hline $\begin{array}{l}320800.1509026 \\
320800.1509028 \\
320800.1509030 \\
320800.1509042\end{array}$ & $\begin{array}{l}\text { DOORS, } 3670 \\
\text { WINDOWS, } 4030 \\
\text { ROLL-UP DOORS, } 20 \times 24 \\
\text { INSULATION, R11 }\end{array}$ & $\begin{array}{l}501 \\
501 \\
501 \\
501\end{array}$ & $\begin{array}{r}2 \\
6 \\
2 \\
4700 \\
\cdots\end{array}$ & $\begin{array}{l}E A \\
E A \\
E A \\
S F\end{array}$ & $\begin{array}{r}8 \\
12 \\
48 \\
38 \\
-\end{array}$ & $\begin{array}{r}246 \\
369 \\
1476 \\
1344 \\
\end{array}$ & $\begin{array}{r}106 \\
36 \\
400 \\
0\end{array}$ & $\begin{array}{r}570 \\
1110 \\
26000 \\
1880 \\
\end{array}$ & $\begin{array}{l}0 \\
0 \\
0 \\
0\end{array}$ & $\begin{array}{l}0 \\
0 \\
0 \\
0 \\
-\end{array}$ & $\begin{array}{r}231 \\
379 \\
6969 \\
806\end{array}$ & $\begin{array}{r}1153 \\
1894 \\
34845 \\
4030\end{array}$ \\
\hline SUBTOTAL & MECHAN ICAL & & & & 1,044 & 33,654 & 10,519 & 111,030 & 0 & 0 & 38,804 & 194,007 \\
\hline
\end{tabular}


FLUOR DANIEL NORTHWEST, INC.

COGEMA ENGINEERING CORP.

JOB NO. 2466AAA3

FILE NO Z466AAA3

\section{ACCOUNT}

NUMBER

\section{DESCRIPTION}

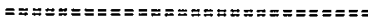

SALES TAX $8.00 \%$

OH\&P (ON MARKUPS ONLY)

TOTAL

\section{COST CODE 50115}

HBS 320800

CESCALATION

$0.00 \%-$ CONTINGENCY

$25.00 \%$

\section{INTERACTIVE
TANK REMOVAL}

241-AX TANK FARM CLOSURE - PLANNING ESTIMATE

PHMCRO8 - ESTIMATE DETAIL BY WBS / COST CODE
PAGE

BY

$05 / 27 / 98 \quad 13: 37: 55$

R. OHRT
DUAHTIY MANHPUPS $======$

MANHOURS

MATER SUB -

SUB -

EQUIP.

MENT

OH\&P

TOTAL

$=\approx==$
8882

1,044

33,654

10,519

119,91
19,912

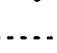

0 $2220 \quad 8882$ $41,024 \ldots . . .$. 205,110 
FLUOR OAHIEL HORTHUEST, INC. COGEMA ENGINEERING CORP.

JOB NO. Z466AAA3

FILE NO. 2466AAA3
** IEST - INTERACTIVE ESTIMATING ** TANK REMOVAL

241-AX TANK FARM CLOSURE - PLANNING ESTIMATE PHMCRO8 - ESTIMATE DETAIL BY WBS/ COST CODE
PAGE 28

DATE $05 / 27 / 98 \quad 13: 37: 55$

BY R.OHRT

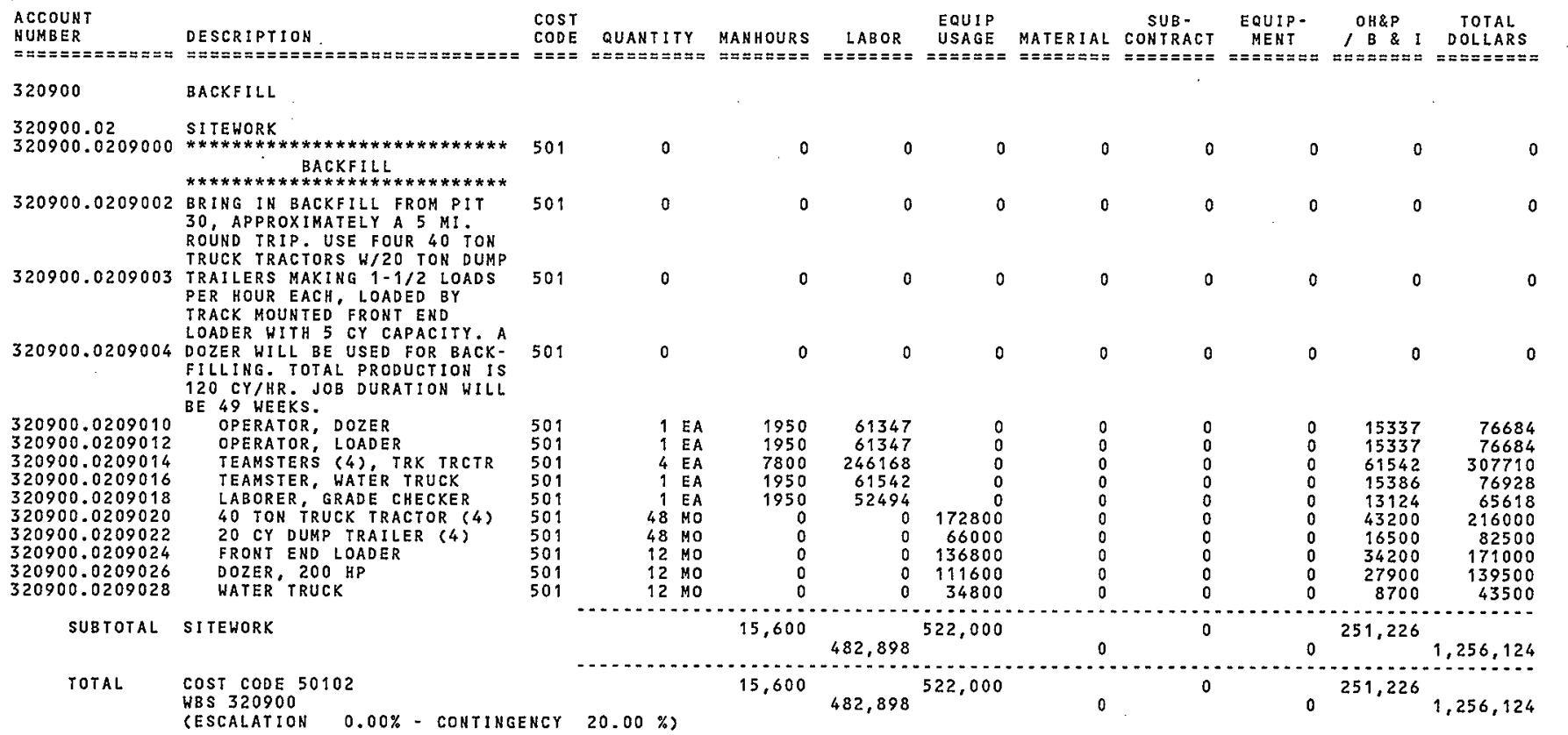

TOTAL HBS 320900 BACXFILL

15,600

482,898

522,000

251,226 
FLUOR DANIEL NORTHWEST, INC. COGEMA ENGINEERING CORP.

JOB NO. Z466AAA3

FILE NO. Z466AAA3

ACCOUNT

INUMBER

330200

$330200.02 \quad$ SITEHORK

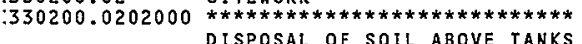
D******************************

:330200.0202002 SUBCONTRACTOR CHARGE TO PICK UP LOADED TRAILERS OUTS:DE 249-AX TANK FARM AND DELIVER TO AND DUMP AT ERDF.

330200.0202003 COST IS \$60 PER TON.

\section{SUBTOTAL SITEWORK}

TOTAL

COST CODE 46002

WBS 330200

GESCALATION

$0.00 \%$ - CONTINGENCY

$35.00 \%$

460

0
DESCRIPTION

* IEST - INTERACTIVE ESTIMATING **

TANK REMOVAL

241-AX TANK FARM CLOSURE - PLANNING ESTIMATE PHMCRO8 - ESTIMATE DETAIL BY WBS / COST CODE

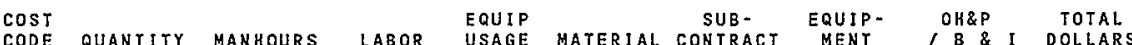

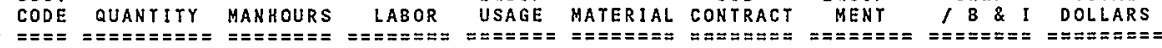

$\begin{array}{rrrrrrrrrr}460 & 0 & 0 & 0 & 0 & 0 & 0 & 0 & 0 & 0 \\ 460 & 27675 \text { TON } & 0 & 0 & 0 & 0 & 1660500 & 0 & 0 & 1660500\end{array}$

$0 \quad 0$

$0 \quad 0$

0

0

0

0

$0 \quad 0 \quad 0 \quad 0$

$1,660,500$

$1,660,500$

0

0

TOTAL WBS 330200 SOIL DISPOSAL - TOP OF TANKS
660,500
1

0
0

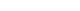

0

$1,660,500$ 


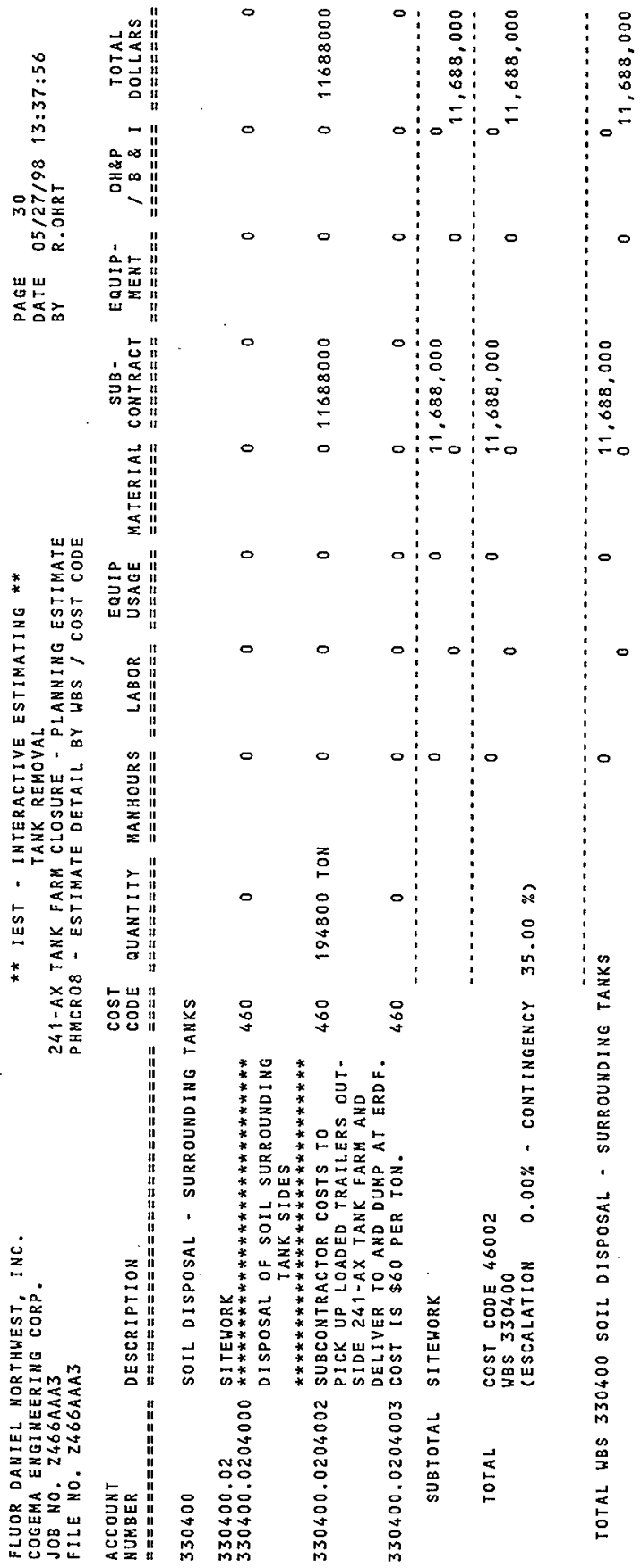

$\infty$
$\vdots$
0 
FLUOR DANIEL NORTHWEST, INC. COGEMA ENGINEERING CORP

JOB NO. Z466AAA3

JOB NO. 2466AAA3

\section{ACCOUNT}

NUHBER

NUMBER DESCRIPTION

330500

DISPOSAL - TANK WALL DEBRIS

330500.02 $330500.0205000 * * * * * * * * * * * * * * * * * * * * * * * * * * * *$ DISPOSAL OF TANK WALL DEBRIS

$\begin{aligned} 330500.0205002 & \text { SUBCONTRACTOR COSTS TO } \\ & \text { PICK UP LOADED TRAILERS OUT- } \\ & \text { SIDE } 241-A X \text { TANK FARM AND } \\ \text { DELIVER TO AND DUMP AT ERDF. } & \text { DER }\end{aligned}$ *****************************

$\begin{aligned} 330500.0205002 & \text { SUBCONTRACTOR COSTS TO } \\ & \text { PICK UP LOADEO TRAILERS OUT- } \\ & \text { SIDE } 241-A X \text { TANK FARM AND } \\ \text { DELIVER TO AND DUMPAT ERDF. } & \end{aligned}$

$\begin{aligned} 330500.0205002 & \text { SUBCONTRACTOR COSTS TO } \\ & \text { PICK UP LOADEO TRAILERS OUT- } \\ & \text { SIDE } 241-A X \text { TANK FARM AND } \\ \text { DELIVER TO AND DUMPAT ERDF. } & \end{aligned}$

$\begin{aligned} 330500.0205002 & \text { SUBCONTRACTOR COSTS TO } \\ & \text { PICK UP LOADEO TRAILERS OUT- } \\ & \text { SIDE } 241-A X \text { TANK FARM AND } \\ \text { DELIVER TO AND DUMPAT ERDF. } & \end{aligned}$

$\begin{aligned} 330500.0205002 & \text { SUBCONTRACTOR COSTS TO } \\ & \text { PICK UP LOADEO TRAILERS OUT- } \\ & \text { SIDE } 241-A X \text { TANK FARM AND } \\ \text { DELIVER TO AND DUMPAT ERDF. } & \end{aligned}$ OF REIHFORCED CONCRETE AT APPROX. 4000 LB PER CY = 4248 TON.

\section{SUBTOTAL SITEHORK}

TOTAL COST CODE 46002

WBS 330500

SESCALATION

$0.00 \%$ - CONTINGENCY

$35.00 \% 2$
* * IEST - INTERACTIVE ESTIMATING * * TANK REMOVAL 241-AX TANK FARH CLOSURE - PLANNING ESTIMATE PHMCRO8 - ESTIMATE DETAIL BY WBS / COST CODE

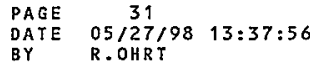

\section{PAGE $05 / 27 / 8$}

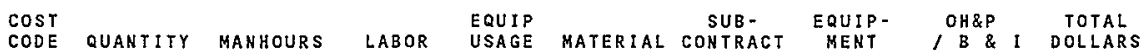

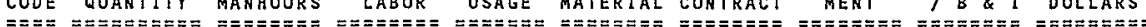

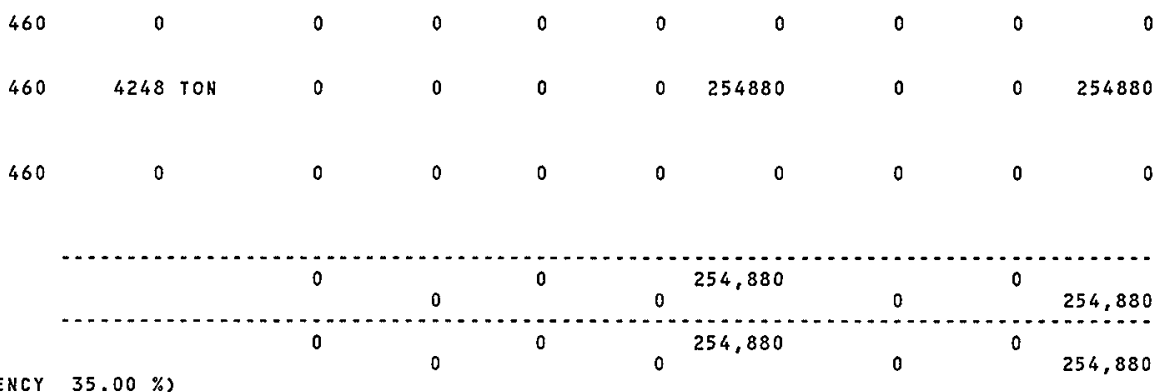


HNF-3378-Rev. 0

FLUOR DANIEL NORTHWEST, INC.

COGEMA ENGINEERING CORP

JOB NO. Z466AAA3

FILE NO. Z466AAA3

\section{ACCOUNT}

NUMBER

DESCRIPTION

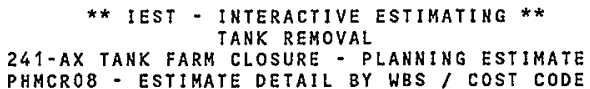

EQUIP

CODE QUANTITY MANHOURS LABOR USAGE

SUB -

MATERIAL CONTRACT CONTRACT
$= \pm \approx= \pm \approx=$
PAGE 32

DATE $05 / 27 / 98 \quad 13: 37: 56$

BY R.OHRT

\section{EQUIP- OH\&P TOTAL}

MENT $\&$ B \& I DOLLARS MENT / B \& I DOLLARS
$323,489 \quad 534,263 \quad 13,735,240$ $16,878,401 \quad 14,318,682$
$0^{2,888,630} 48,355,218$ 


\section{CORRESPONDENCE DISTRIBUTION COVERSHEET}

Author

W. A. Skelly
Addressee

Distribution
Correspondence No.

HNF-3378-Rev. 0

Subject: AX Tank Farm Tank Removal Study

DISTRIBUTION

Approval Date Name Location w/att

Correspondence Control

A3-01

HTI Project Files

$\mathrm{R} 1-41$

DOE/RL Reading Room

Cogema Engineering Corporation

J. A. Hunter

B4-51

D. C. Ramsower

B4-51

W. A. Skelly

B4-51

Document Control

B4-51

DOE-RL Operations

C. D. West

A0-21

Fluor Daniel Hanford, Inc.

L.E. Borneman

A3-03

P. A. Scott

K9-46

Informatics

R. W. Root

R2-53

Jacobs Engineering Group. Inc.
J. C. Henderson
D. L. Nichols
B $1-40$
B $1-40$

Lockheed Martin Hanford Corporation
E. A. Fredenburg
R1-04
R. W. Powell
R3-75
W. J. Stokes
R3-75 
Numatec Hanford Corporation

$\begin{array}{ll}\text { D. L. Becker - } 2 & \text { R2-89 }\end{array}$

T. J. Conrads R3-73

L. B. McDaniel R2-89

Pacific Northwest National Laboratory

A. F. Noonan K9-91

T. L. Stewart K5-25

Waste Management Hanford

J. C. Sonnichsen

H6-26 